

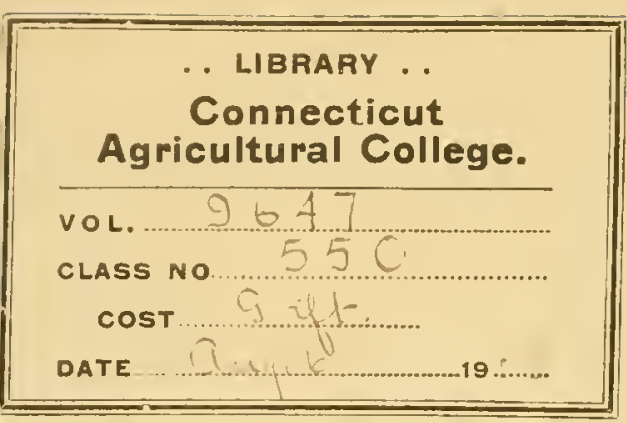



Digitized by the Internet Archive in 2009 with funding from

Boston Library Consortium Member Libraries

http://www.archive.org/details/pseudoceratiteso00hyat 
DEPARTAENT OF THE INTERIOR

\title{
MONOGRAPHS
}

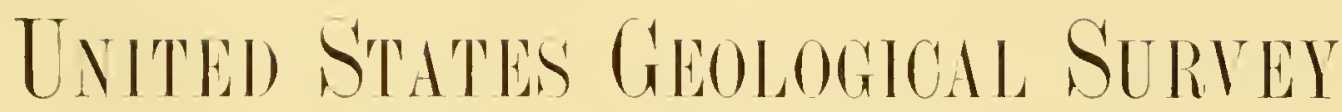

\author{
TOLIME NLIV
}

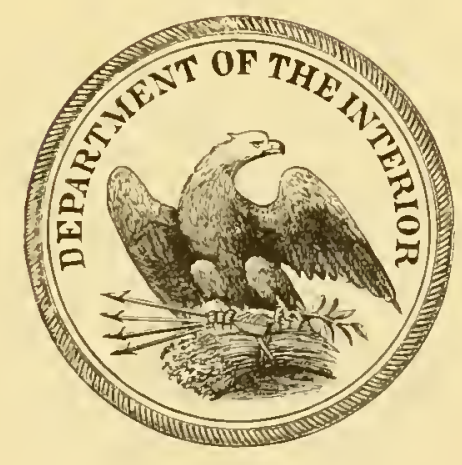

IVASIIINGTON

GOVERNAENTRINTING OFFICE

1.903 

UNITED STATES GEOLOGICAL SURVEY

CHALLES I). WALCUTT, IIRECTOR

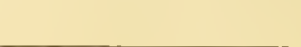

\section{PSEUDOCERATITES OF THE CRETAOEOUS}

ALPHEUA HYATT

Edited by T. W. STANTON

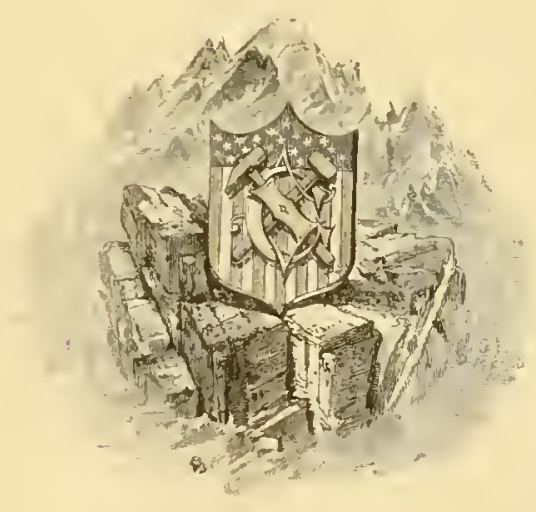

WASII N GTON

GOVERIMENT PIINTING OFFICE

1,118 
2647 


\section{CONTENTS.}

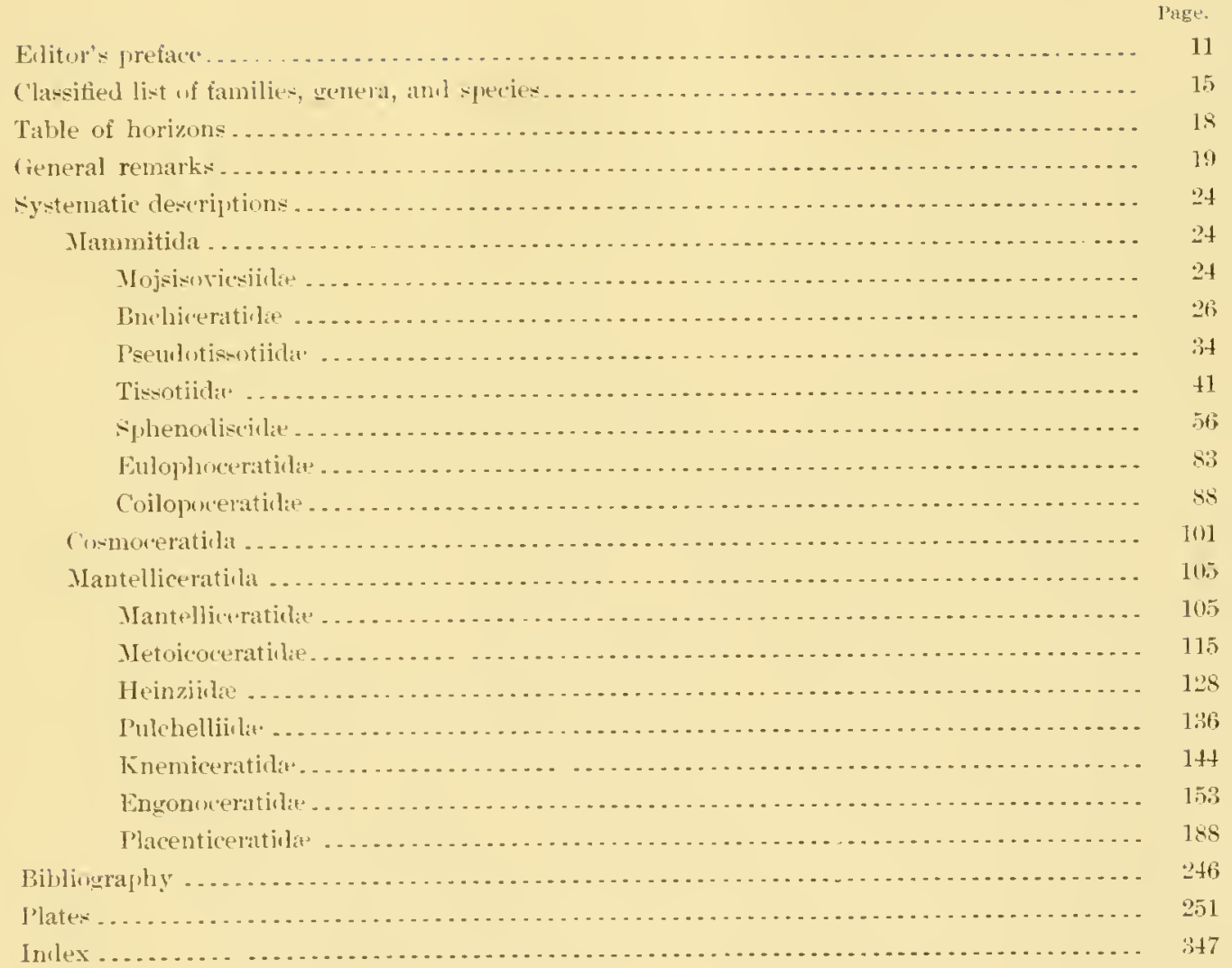





\section{ILLUSTRATIONS.}

P'Late 1. Figs. 1-3. Mojsisovicsia Ilurfelili steinmann

t-9. Buchiceras bilohatum Hyatt

10-14. Romeroceras syriaciforme Hyatt

15. Rnemeroreras attenuatum (IIyatt)

I1. Figs. 1-3. Roemeroceras galihi II yatt

4-6. Ioemeroceras subplanum Hyatt

7-11. Paratissotia serratid (Iyatt)

III. Figs. 1-6. Pilratissotia regularis 1 ỵatt

7-15. Sphenodiceus pleuricepta (Conrad)

IV. Figs. I, 2. Sphenodiscus pleurisepta (Conrad)

V. Figs. 1-3. Aphenodiscus pleurisepta (Conrad)

4. Sphenodiscus stantoni Hyatt

Page.

2. Sphenodiscus lobatus (Tuoney)

3, 4. Sphenodiscus leecheri Hyatt

5. Sphenoulisens stantoni Hyatt

6. Sphenodisus plenrisental (Comad)

VI. Fig. 1,2.
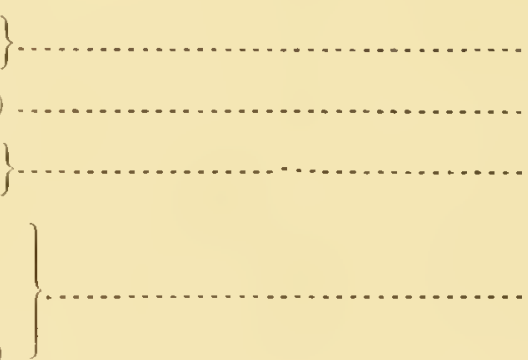

V11. Firs. 1,2. Sphenorlisens lolutus (Tuomey).

VIII. Figs. 1, 2. Sphenoliscus lenticularis (Owen)

3-7. Sphenodiscus lenticuiluris var. splendens II yatt

IX. Figs. 1-6. Fiphenodiscus lenticularis (owen)

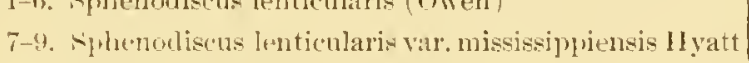

10. Siphenowisens heecheri Il yatt

11-13. Sphenorliscus lohatus ( Tuomer)

I. Figs 1-4. Coilopoceras novinexinamon Hyatt

5-21. Coilojwceras colleti 13 yatt

X1. Figrs. 1. Coilopoceras colleti Hyatt

"2-tia. Euluphuceras natalense Hy att

7-24. Metoicoceras swallovi (Shumarl)

111. Figs. 1-3. Cuilopoceras springeri Hyatt

4-6. Aconeceras nisum (al'orligny)

7. Coiluporeras grusonver Jyatt

8. Sihenuliscus konineki Hyatt 
PLITE XIV. Figs. 1-10. Mletuicuceras whitei Hyatt

Page.

11-14. Metoicueras acceleratum Hyatt

15. Metnicoceras whitei II yatt

16. Vascoreras hartti Hyatt

XY. Figs. 1-4. Metoieccras swallovi (Shumarl)

5-8. Metuidaceras giblosmu $\mathrm{Hyatt}$

9-11. Detoicoceras kanabense Hyatt

12-18. Heinzi: natura Hyat

1y-20. Iheinzia J rovincialis (d'Orbigny)

XT1. Figs. I-3. Heinzia provincialis (l'Orbigny)

t-8. Knemiceras syriacum (ron Buch)

9, 10. Knemiceras conıregemm Hỵatt

11-14. Knemiceras compressm var. subcompressum

$$
\}
$$

19. Knemiceras compressum var, subrompressum

XVII. Figs. 1-5. Subpulchellia castellanensis Ilyatt

ti-s. Nicklesia dumasiana Iyatt

4-12. Pntchellia coupressisima (I'Orbigny

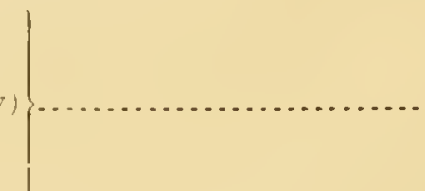

286

13-15. Knemiceras attenuatum (IIyatt)

16-20. P'rotengonnceras gabbi (Bïhm)

XY111. Figs. 1-3. Fnemiceras galbi 11 yatt

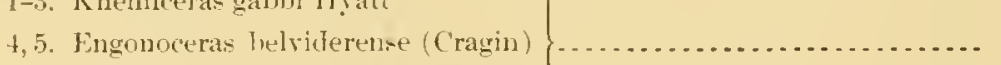

6-9. Protengonueras planum Hyatt

XIX. Figs. 1-ti. Engonoceras uddeni (Cragin)

7-14. Enyonoceras serpentinum (' 'ragin)

15-17. Engennoceras retardinn Hyatt

XX. Figs. 1-5̃. Engonoceras serpentinum (Cragin)

6-13. Engonoceras pierdenaje (von Buch)

IXI. Figs. 1. Encronoceras pierienale var, commune Hyatt)

2-6. Engonoceras suljectum Hyatt

XxIl. Figs. 1-ī. Eugonoeras subjectun llyatt,

6-10. Engonoceras gibhosum Hyatt

Xxill. Figs. 1-6. Engonoceras gibbown Hyatt

7-4. Engonoceras stolleyi Piihm

$\mathbb{X} \times 1 \%$. Figs. 1-5. Engonoceras stolleyi Bühm

6-8. Engonoceras complicatum Hyatt

$\mathrm{XXY}$. Figs. 1-4. Tenlubites cluffati llyatt

5-9. Metengonoceras inscriptum Hyatt

XXY1. Figs. 1-4. Metengonoceras inscriptum llyatt

5-7. Meteugonoceras ambignum Hyatt

s. Mrtungonoceras acutum 11 yatt

XXYI1. Figs. 1,2. Metengonoceras acntum lfyatt

3-14. Metengonuceras rlumbli (Cramin)

15-17. Placenticeras syrtale (Morton)

XXVill. Figs. 1-6. Ilacenticeras syrtale (Mortru) 
Plate XXIX. Figs. 1-t. Placenticeras gnalalupa (Roemer) . . . . . . . . . . . . . . . . .

IXX. Fig. 1-3. Placenticeras sancarlosense Hyatt ....................... :12

XXXI. Figs. 1. 2. Plarenticeras sancarloense Hyatt

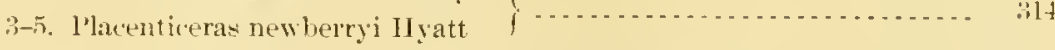

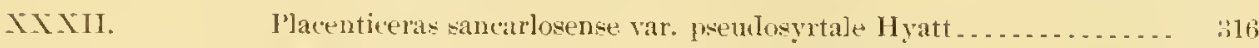

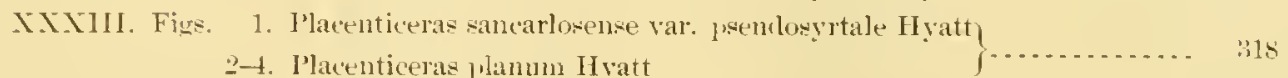

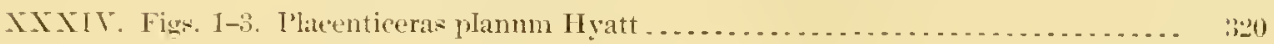

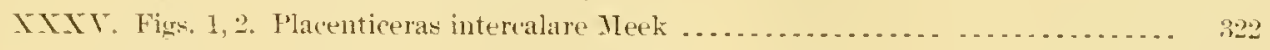

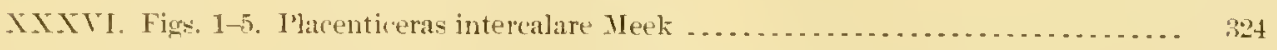

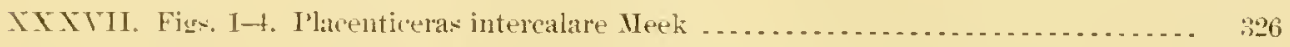

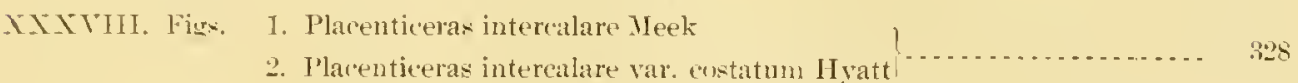

XXXIX. Figr. 1, 2. I"lacenticeras interealare var. contatum Iyatt

3-6. Pacenticeras placenta (Dekay) Y.................

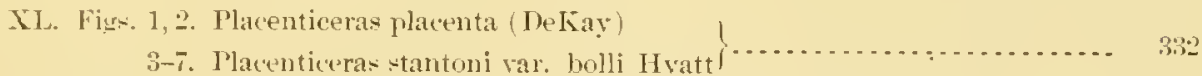

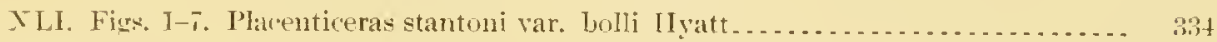

XLII. Figs. 1, 2. Placenticeras stantoni var. bolli 1 Iyatt $\ldots \ldots \ldots \ldots \ldots \ldots \ldots \ldots \ldots \ldots$. . 33 ;

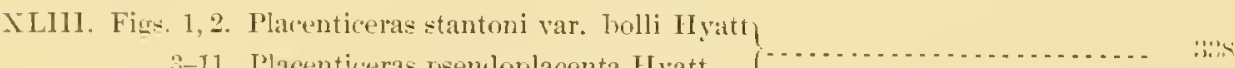

:3-11. I'lacenticeras penmloplacenta Hyatt j

XLIV. Figs, 1-3. Placenticeras psemloplacenta I lyatt . . . . . . . . . . . . . . . . .4t)

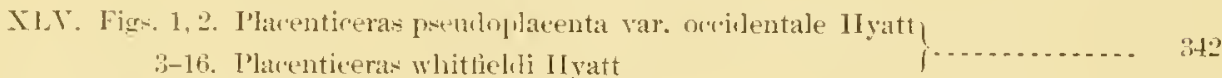

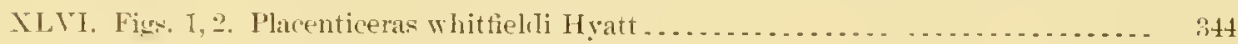

ILV11. Figs. 1-4. Placenticeras whitfielni IIyatt

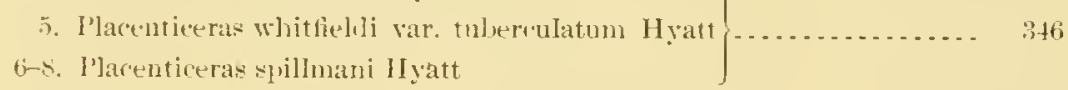





\section{EDITOR'S PREFACE.}

Soon after Professor Hyatt's lamented death, Jamury 15, 1902, it was the writer's sad duty, as a representative of the United States Geoological Survey, to examine all the paleontological collections and manuscripts in Professor Hyatt's house in Cambridge, in order to take possession of those belonging to the survey. The manuscript of the present volume was on his desk and rontains the results of his last work, in which he was actively engaged on the day of his death. Fortunately it was almost ready for the printer, and although the careful reading of the manuscript to determine the author's exact meaning and intentions has consumed considerable time, the changes, either in arrangement or in wording, and the additions that have been found necessary are very few indeed. These changes are all indicated in their proper places by footnotes or bracketed statements signed by the editor's initials, except the numportant rerbal change of "Cretacic" to "Cretaceous," made for the sake of confornity with Geological Surey usage. In his recent writings Professor Iyatt consistently followed the International Geological Congress mle of ending names of all periods and systems with "ic."

The preparation of this work occupied a large part of Professor Hyatt's time for several years. As early as 1997 a manuscript with the same title was submitted to the Director of the United States Geological Survey for publication, and soon afterwarls the preparation of the illustrations was hegun. A copy of this original manuscript now in ny hands shows many important differences in arrangement, classification, and nomenclature from the later manuscript, indicating that it had been thoroughly revised and recast in connection with a restudy of the fossits.

Althom the are sone minor inconsistencies, and there would doubt- 
less have been some other changes and additions if the anthor had lived to see the rook though the press, it is believed that as mow published it fairly presents his latest rieds. The illustrations were all male unler Professur IY ratt's smpervisim, except a few, which were definitely selected and indicated by him, and most of which are copies of publisher figures. He harl also mounted the figures on the first twenty plates and had written the descriptions of nineteen of the plates. The other figures were nearly all labeled with specific names. 'T'he mannscript was in two parkages, one of which began with the "General lemarks," followed hy I'uldhelliidae, Knemiceratidae, Fugnocerstidac, and Placenticeratidex, which is nearly the arrangement of the original manuscript of 1897 , while the second packige

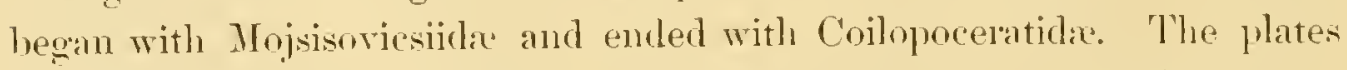
arranged by the author contain all the illustrations except the Placenticeratidae and a part of the Engonoceratilae. By transterring the introductory "General remarks" from one package to the other and then uniting the two packages the descriptions fell into practically the same arrangenent that was aclopted for the figures, and which evidently represcuted the author's latest riews as to their relationships. The assigmment of the families to higher groups was not fully carried ont by Professor Hyatt, and it is thought best not to attempt to complete it, in view of the fact that his opinions as to the definition and limits of the different superfanilies evidently were much mulifich, thongh never formulated, after the publication of his chapter on Cephaloporla in Zittel's Text-lowk of Paleontology. In that work he divides the Ammonoidea into several suburders, and between these and the families there is another mumamed category of gromps, which may be called superfamilies, such as Manmitida, Cosmoceratida, etc. Part of the Pseudnecratite families are there referred to Mammitida, part to Placenticeratida, the Pulchelliidae were accidentally omitted, and other families were not there described. In the present paper a list of the families belonging to the Mammitida is given, but beyond that gunu the classification is doubtful. In connection with the description of Vaseoceras, Cosmocemtida is mentioner in such a way that the reference of the genus to that gromp may he interred. and later in the manusupt the heading Iantelliceratida is inserted, but there is nothing to wanlant the assumption 
that the latter term was intended to inchde Heinziidax, Pnlchelliidre, Knemiceratide, Engonoceratide, and Placenticeratide. In the pullished work above referred to, the two families last named are united with sphenodiscidx to form the Placenticeratida, but with the removal of sphenodis. cida to Mammitida it seems probable that the superfimily Platenticeratida was abandoned.

The multiplication of families, genera, and species will be understoon by all who are acquainted witl Professor Hyatt's halbit of attempting to express in the terminology every important fact observer in the comse of his investigations.

In characteristic fashion the anthor plunges into the midnt of lis sulject, beginning lis introduction with a discussion of the sutural details of Jurassic ammonites, not tarying even to define the title of the paper on to make a formal statemenr of the problems involved. In a fintuote on page 546 of Zittel's T'ext-book, where he first used the term l'sendoceratites, he states that it "is a descriptive expression for the Placenticeratida and Tissotide of the Cretaceons, which are morphic equivalents of some Triassic genera of the Discocannpyli as regards both suture and shell form. Their origin is traceable, however, to different groups of the l'achyeampyli, a suborder which appears to have been initiated in the Jura along witl the Leptocampyli. It is, therefore, inprobable that the Psendoceratites were directly connected with the Triassic Discomampyli." In a letter written December 26, 1901, in response to an inciniry from the Geological survey office. lee gives the following some what more definits statement of the scope and purpose of the present work: "I an at work finishing a "Monograph of the Psondoreratites of the Cretacie.' 'This is an artificial gronp, inchding, for convenience of treatment, all the retrogressive genera of the Cretacie that lave sutures with simple outlines resembling those of Triassic ceplatopors, formerly included under the name Ceratites. The known genera described aul fignred are Buchiceras, T'issotia and its allies, Sphemodiscus, Kneniceras, Engonnceras, Placenticeras. The aim of this publication is to give as full treatment as possible of the structure and relations of these genera, in order to determine as far as practicable to what groups among the nomal progressive forms they are most nearly related." 
It was Professor Hyatt's constom, in citing the antlority for a speries, to give the name of the anthor who first refermed the spereies to the genus in which it is now retainerl, instear of citing the one who tirst proposed the specific nane. 'T'hus he wrote I'lacenticeres placentu Meek, although the form was described as Ammonites plucentu by Dekay. This is not in accordance witl the rule usnally followed by zoologists, and the citations have been changed so that each specitic name is followed by the name of the origmal describer of the species, with the anthor's name in parentheses if the gencric reference has been changed.

When the figured specimens were at the Genlogical Survey in the hands of the artists, Professor Hyatt requested the writer to examine them carefully and give him notes and comments as to the localities and horizons of the specimens from his own collection and from uther musemms. The quoted statements concerning various species that appear in the mamseript were extracter from the notes the writer then forwarderl to him.

The appended tabular statement is intended to show the relative positions of the varions marine Cretaceons horizons and formations mentioned in the text. It does not imply accurate correlation of American and European lorizons, the line between Lower and Upper Cretaceous being probably somewhat higler in America than in Europe.

The figmed specinens that are mentioned in this paper as belonging to l'rofessor Hyatt's private collection have now become the property of the Musem of Comparative Zoology in Cambridge.

The writer has supplied the table of contents, the formal bibliograplice list, and the descriptions of the plates after Pl. XIX.

T. W. STANTON. 


\section{(CLISSIFIED LIST OF FIMILIES, GENERA. AND SPECILS.}

In the following list all the gromps that are clescribed and all the species that are definitely referred to the genera herein treated are arranged according to I'rofessor Hyatt's rassification as given in the text. The purpose of the list is to bring together in compact form for easy reference the large number of dercribed species that are here referred to new genera.

The classification is incomplete and in sume cases probably misleading. For example, some of the genera under Comoceratida are not assigned to families, and it is very doubtful whether Professor Hyatt intended to place in Mantelliceratida all tle families here arranged moler that superfamily. It is evident that the anthor's published views concenning that group had changed, but unfortunately he had written un revised description. It is therefore necessing to lave the groups classified accomding to the arrangement of the mamnseript without inserting the names of any otler superfamilies.

T. W. S.

MAMMITIDA.

MonsmovtCAIDX.

Yojsisoviesia Fteinmann. durfeldi.

Buchicelatipla.

Bucliceras Hyatt.

hilnitratım.

Iovemenceras Hyatt.

gahibi.

syriaciforme.

attenuatum.

Mubilanum.

PsecinotisiotidD.

Premdoti-sotia Peron.

gatliennei.

tunisiensis.
Choffaticeras Hyatt.

barjonai.

meslej.

donvillei.

Hemitisutia Peron.

('azini.

batnensis.

morreni.

tisutieformis.

djelfensis.

ceadnuroensis.

Plesiotiswotia F'erom. michaleti.

\section{Tismotilde.}

Tissotia Dourillé. tiscoti.

Subtirertia Hyatt.

iufluta.

internedia.

peroni.

africina. 
Metatiwnotia II yatt.

formeneli.

rohini.

norkwis.

haplophylla.

emalili.

auressemsin

sliz?wix $z$ i.

Paratimsotia 11 yatt.

grosisnurei.

thoniasi.

ficheuri.

serratat.

regularis.

\section{INCERT L SEDIS.}

Tissotial c'ssoni.

globo-a.

Heterotissotia Perum.

nerceratites.

\section{PPHEXODISCID.}

Incloceras Noetling.

balubhistanense.

antorlorsatum.

Lilucoceras llyatt.

ismate.

Sullenorincus Meek.

l) leurisepta.

lobatus.

stantoni.

lenticularis.

var. silenilens.

var. missis-ippiensis

heecheri.

konincki.

limekhorsti.

nlyagshi.

rutoti.

siva.

Fulophocenatide.

Tegoceras 1 y yatt.

mosense.

Lenticeras ferhardt anclii.

P'ulalenticeras Hyatt. sieversi.

Euloulurerar Hyat. nitalense.

COILOPOCERATID A.

l'atylenticeras Hyatt.

lieteropleurum.

peeditorrasianum.

gevrilianum.
Coilopocera- Il yatt.

colleti.

novimexic:antum

springeri.

rexplenianum.

growsistrei

Aconeceras 11 yatt.

nisım.

\section{COSMOCERATIDA.}

Vancocerals chofitat. liartti.

Tolypeceras 11 yatt. marcousanum.

Barroisiceras firnssure. desmoulinsi.

baneri.

\section{IANTELLICERATIDA.}

\section{Maytelliceratibe.}

Metasigaloceras $\mathrm{Il}$ yatt. rusticum.

Psemlaspirloceras 11 yatt.

forteanum.

ronciliatum.

cunlitti.

crassitesta.

euomphatum.

decirlunm.

schlüteri.

Diallechoceras II vatt. nodowocretatum.

Pedioneras Gerhartt. cumlinanarese.

caquesensis.

ubaruensis.

Douvilleiceras Grossoure

mammillare.

orlignyi.

spiniferulu.

Schluetericeras Ilyatt.

nodowiules.

vielbanci.

laulsei.

michelubense.

- harpeiceras Il ratt.

laticlavium.

seldlueteri.

incoustams.

Aeonymororas II yatt.

hodhumense.

exacmlense.

renevieri 
Mantelliceras Hyatt.

mantelli.

couloni.

pieteti.

vicinale.

ushas.

indianense.

domeykanum.

\section{METOICOCERATIDA.}

Ietoicoceras $\mathrm{H}$ yatt.

swallovi.

gibbosum.

whitei.

acceleratum.

\section{HEINZIIUA.}

Heinzia sayn

sayni.

corioli.

heinzi.

hispanica.

pulchellitormis.

provincialis.

matura.

ouachensis.

Carsteuia 1 yatt.

lindigi.

eaicerli.

subcaicedi.

tuberculata.

galeata.

Gerharitia llyatt.

galeatriiles.

galeatus.

releziensis.

\section{Pulchellitof.}

Nicklesia Hratt.

moltoi.

levir.

nolani.

lapparenti.

alicantensis.

karsteni.

lenticulati.

diclayana.

dumaian:l.

Subpulchellia IIyatt.

oehlerti.

fouquei.

sauvageaui.

castellanensis.

ION XLIV-03- 2
Pulchellia Thlig.

nieklesi.

sellumbergeri.

columbiana.

selecta.

het tneri.

changarnieri.

kiliani.

onachensis.

compressissina.

Psilotissotia Hyatt.

chalmasi.

mariolie.

lefforgesi.

reigi.

haugi.

Lophobolites Hyatt.

cotteaui.

\section{KNemiceratide.}

Knemiceras Bühnt.

syriacum.

compressum.

var. subroupressum.

atteunatum.

gablui.

uhligi.

\section{ENGoxoceratid E.}

I'rotengonoceras Hyatt.

gublii.

planum.

enarginatum.

Fngonoceras Nemnayr.

bel virlerense.

whleni.

serpentinum.

pierilenale.

var. coumune.

subjectum.

gih)w:min.

stollevi:

complieatum.

emarginatum.

memeri.

Neoluhites Fischer.

vibrayeanus.

choffati.

peroni.

Metengonoceras II yatt. inacriptum.

aubiguum.

acutum.

dumbli. 


\section{Placexticeratid a.}

Placenticeras Mleek.

guarlalupe.

-ancarlosense.

var. jwendosyrtale.

planum.

newberryi.

syrtale.

var. lialei.

interealare.

placenta.

stantoni.

var. bolli.

pseudoplacenta.

var. uccidentale.

whitfieldi.

var. tuberculatum.

spillmani.

telifer.

? faliax.

elurayi.
Placenticeras warthi.

nemoria-schloen bachi.

depressimn.

grossomrei.

incisum.

milleri.

schlïteri.

orbignyanum.

jolyopis.

rrassatum.

tamulicum.

jwendorl,ign yanum.

subrilistriatum.

I)iplacmoceras Hyatt.

birlorsatum.

caualiculatum.

\section{IXCERTA SEDIS}

Styracoceras Hyatt.

balduri.

Tuble "f horizons mentioned in thes unth.

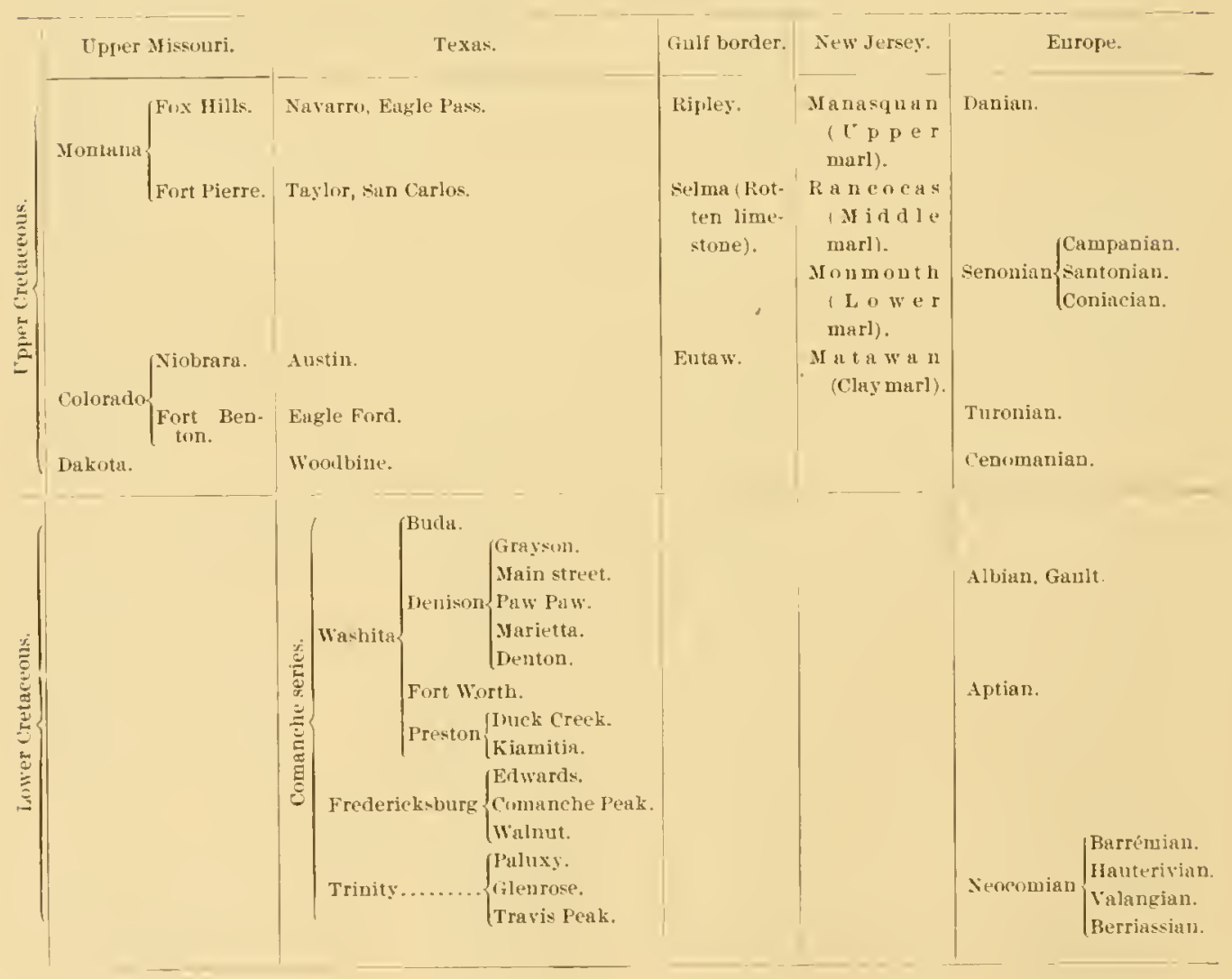




\title{
PSELDOCERATITES OF THE CRETACEOLS.
}

\author{
By Miplievs Hyate.
}

\section{GENERAL REMARKS.}

So far as I have been able to see, either in figures or in specimens, the Ammonitine of the Jura liave only one large tirst lateral lobe, even in lighly involute forms, as demonstrated hy the admimble researches of Buckman ${ }^{2}$ upon Hypentioceras disroidum, subdiscoidum, ete, and the same has been shown by Opprel's tigures of Nemayria discus, hochstetteri, and aspidoides, and Quenstedt in Amm.trnelli, ${ }^{c}$ and the similar liollon-keeled forms alsoin Nenmayria serrodens (pls. 24, 69), Lolyplectus discoides, and rapellinus (pl. 53), which have a very deeply divided and double first lateral, and in Nemayria discus (pl.57) in which there are apparently two or the principal laterals, but in the neanic stage only me bifid furst lateral 'The Arietidae seem to have tro principal saddles owing to the great development of first auxiliary, but this occurs only in the ephebic stage. Aspriloceras and some forms of other genera often have two well-divided prineipal lateral saddles, but this again oceurs throngh the late division of the prinitive lateral.

In fact, it may be confidently stated that in the Jura all of the Ammonitinze have but one principal lateral saddle thronglont the neanic stage, and when, as very lately occurs, two or three principal laterals are either apparently or actually developed, they oceur as purely secondiry, or ruther, tertiary developmental changes in the ephelpic stage.

'This fact is of importance because of its bearing upon the biology of Ammonitina in the Cretacens. With regard to these, it may be stated that they are distinctly tachygenetic or accelerated in developnent when

\footnotetext{
"Inferior (ostite Ammonites: Palant. Soc., Vol. II, I'p. 40-19.

b Pal. Mittheil,, pl. 4.

cAmm. 1. schwïh. Jura, pls. 24, 69.
} 
compared with the Anmonitina of the Jum. All of the forms so far investigated, which have more than one prineipal lateral saddle and lobe, acquire these characters a stage earlier than the Jumssic species. They appear, as stated above, in the neanic stage and are secondary modifications of the outlines of the prinitive first laterals of the nepionic stage.

The sanc law seems to hold in a modified way for the development of an extra number' of auxiliary lobes and saddles such as appear in Neumayria, but my materials have not enabled me as yet to follow this out. This statement appears at first sight to be antagonized by that made with reference to the arrested derelopment of the sutures in genera like I'motengonoceras, Engonoceres, etc, which have undivided or bifid saddles and lobes only slightly digitated at their extremities. But it will be shown in the generic description of Placenticeras that the arrest of development takes effect in these Psendoceratites of the Cretaceous only after the three principal lateral saddles and lobes are formed in the neanic stage. Consequently, up to this stage, the development is more complex than in the roung of Jurassic species or any others which have only one principal lateral at the same age. 'This statement elears up the extraordinary relations of these forms to their apparently more complicated allies of the Jurassic, and accounts also for the apparent discrepancy existing hetween the highly involute compressed character of the whorls during the neanic stage and the very simple aspect of the lobes and saddles; that such highly involute compressed forms in the Jura, usually combined with the development of highly complex lobes and saddles, has been recorded by me in other papers and by many other writers; consequently, when one meets the Psendoceratites of the Cretaceous he is apt to inagine them to be what Barrancle has called "antachonisms," and diffienlt problens for the evolutionist. They are unquestionably difficult, but they are, $n 0$ more anachronic than any of the forms usually named as having this paradoxical character. They are simply excellent examples of arrestation of development taking effect forally and upon certain structures. These, if 1 have rightly understood the researches of my decemsed friend, Professor Cope, the most brilliant investigator and profoundest thinker on evolution that America has produced, are good examples of his law of retardation in development, and also excellent examples of the different way in which 1 look upon the same phenomena. 1 have never regarded such cases as examples of a tendeney 
to retardation of development. A distinction exists between arrestation and retardation in development, which is of great importance. Arrest of development occurs in many ways. It may take effect locally, as upon the sutures, stopping them from developing in complexity of ontline beyond a certain measure, and thus retaining a semblance to their own yomg and apparently reverting to the condition of the same parts in more ancient anmals of their own stock. It may take effect upon the whole oryanism, as in Baculites and other uncoilud forms, apparently cansing the entive animal to revert in its claracters to a primitive form. There are inmmerable degrees between these two extremes which it is not necessary nor appropriate to mention here. Retardation is distinct from these and of much rarer occurrence."

The derelopment "an not he said to have been retarded in these retrogressive forms, since it begins and for a certain period in the ontogeny progresses in parallel lines with the ancestors of the group, but passes through the modifieations more quickly aceording to the law of tachygenesis. After this its progress is quite suddenly and decidedly arrested, and the suceeding stages are no longer parallel with those of then ancestral forms. The complexity of the outlines of the lobes and saddles in species of Engonoceras, for example, does increase even in the later stages; but this increase is rery slight, and the result is a retrogressive form that minies to a certain extent primitive forms among (xoniatitina and Ceratitinae. Such examples may, nevertleless, belong to the highly accelerated class, as is shown by the earlier development in these Psendoceratites of the Cretaceous of the three principal saddles that only appear in the ephebic stage of the highly progressive forns among Ammonitinat of the Juri. Retardation of development certainly does not take place in their early stages. Can it be said to take place because they do not subsequently proceed to develop numerous marginal lobes and sadrles on the border's of these sane lobes and saddles?

Retardation of development can mean but one class of phenomena, viz, those cases in which a character appears in the ontogeny of descendants later than the stage at which it appeared in the life of their anrestors. In cases of retrogression such as are noted above, and in all examples of this class with which I am acquainted, the complication of the lobes and

"Bioplastology and related branches of biologie restarch; Proc. Boston soc. Nat. IIist., Vol. XXVI, p. 79, etc. 
saddles by the addition of marginals during the later stages of the ontogeny does not orcur; the inexact parallelism is produced by the dropping ont of this stage completely, not by its later and later developnent.

Cope, in lis great work Origin of the littest, wites as follows: ${ }^{a}$

* * * The acceleration in the assmuption of a chancter. progressing more rapidly than the same in another character, mnst soon produce, in a type whose stages were once the exact parallel of a permancut lower form, the condition of inexact parallelism. $A$ all the more comprehensive groups present this relation to each other, we are compelled to beliers that acceleration has been the principle of their successive evolution during the long atgen of greologic time.

Euch type has, howerer. its day of supremacy and perfection of organiom, and "l retrogression in these respects las suceeded. This has, no doubt, followed a law the reverse of acceleration, which has been called retadation. By the increasing sowness of the growth of the individuals of a gems. and later and later assumption of the charactern of the latter. they would be successively lost.

To what power shall we axcribe this acceleration, by which the first beginnings of structure have accmmulated to themselves through the long geologic ages romplieation and power, till, from the germ that was sealcely born into a sand lance. a human heing climbed the complete scale and stood easily the chief of the whole? *** $*$

Acceleration significs addition to the mumber of those repetitions during the period preeding maturity as compared with the preceding generation, and retardation signitien a reduction of the nmmbers of such repetitions during the same time. ${ }^{b}$

Thus, from Cope's point of view, tachygenesis is the law of prugression, and retardation is the law of retrogression, and they are both essential parts of his law of acceleration and retartation.

These quotations show that we botl have the same conception of the proper use of the word "retardation," but we differ in the application of it. Ile applied it to such cases as are described here anong P'sendoceratites, whereas I regard these as true arrests of development and not as retardations.

Retardation is exceedingly rare anong Ammonitinat, and as a rule in otler parts of the animal kingdom, and the only examples l am able to cite are like those given helow in I'acenticeras, where the more complex species like whiffich, that are obvionsly descended from speries like I'. syrtale, have apparently the uodes and ondments smaller and fleveloping, as a rule, later than in that species, and finally, in extreme forms like those of typical rhitficldi, disappearing altogether.

$$
\text { (t) P. } 142 .
$$


As a rule, amoug Ammonitine the reverse is the case, and the disappearace of chameters takes place through the earlier and earlier development and shorter and shorter life history of each characteristic, or thromgh tachygenesis, as stated and illustrated in many of my papers. Here I have space only for one quotation, which will serve to show my meaning more plainly:

Specialization by reduction of parts is evidently includer under the head of retardation ly. Cope: thus in Origin of the Fittest (p. 358), he says that " clange of structure during growth is accomplished either hy addition of parts (aceeleration) ol" by subtraction of parts (retardation)." so far as my "xperience goes, in the major number of asses the parts or eharacters that are undergoing reduction disappear accorling to the law of tallygenesis. They realpear in the ontogeny at earlier and earlier stages, ol exhibit this tendeney in the same way as characters of the progressive clasis, but their development is not so complete as in aneestral forms. In this anse they can be regarded as retarded or thrown baek in their devolopment. There is, howerer, another way of formulating the expression of this. Instead of regarding this disappearance by retrogressive graditions as due to a tendency opposed to acceleration. is it not a tendeney of the same kind! That is to say do not the parts and characters show a tendeney to clisappear earlier and cartior, and are they not in most cases at the time of disappearance present only in earlier stages of growth than that in which they originated in aneestral forms!

Is not the case of the wisdom treth exceptional: The frequently extremely late external appearanee of these is not accompanied hy a later origin of their rudiments in the jaw. Although they may not appear in many cases above the gum until a person is past fifty, is not this real retadation due primalyly to the fact that they are deficient in growth power (tending to disappear from disuse, atc.), and recondarily to their internal position! When they cease to be able to break through the gum will they not still continue to derelop at the rame stage as the other teeth, and will not their rudiments be likety to be presint at this early stage long after they have ceased developing into perfect teeth! "

'The whalebone whales are examples of this kind so fial as the teeth are concerned, although here the disappearance is correlated with the development of whalebone from the rugre of the roof of the nouth. Nevertheless the suppression of the teeth in full-grown animals does not take place by later and later development, and the rudiments of the teeth ane still present in the early stages. 


\section{STSTEMATIC DESCRIPTTONS.}

\section{MAMMITIDA."}

This group in my chapter on Cephalopola in Zittel's Text-hook contained a number of keelet fanilies, in which either the keel was preceded by a median line of tuber'nles, or, if this stage were omitted, the smooth keel arose upon the renter in forms that were apparently closely allied to the more primitive genera having these tubereulated keels. The Mammitida inchuded Mammitidx, Peroniceratidx, Prionotropidx, Hystatoceratide, Lenticeratide, and Tissotiidx. To these 1 propose to add now the Inojsisovicsidle, Buchiceratida, Psendotissotiidec, Eulophoceratide, Sphenodiscidx, and Coilopocerntide.

\section{MOJSISOVICSIIDAE Hyatt.}

The single genns and species described below can not be even provisionally inchuded in any of the gronps to which it is supposed to be nearly related, and the following discussion of its generie affinities shows this conchnively. The dorsal sutures are not yet known, and this is the mly defect in the evidence that establishes it as an independent group, proba'bly belonging to the parent stock or stem of the Pachycanpyli.

\section{MOJSISOVICSIA Steimmam.}

The interesting species used is the type of this genus has a form which is similar to that of Agassicerus of the Lower Lias in being smooth and discuidal, with flattenerl sides, narrow umbilical zones and rounded venter. The section is what I have called helmet shaped, like Ayas. striaries. It differs in having no raised line or keel, and therefore comes a little nearer to I'siloceras. The sutures bear a similar interpretation, since, although these are rery immature, there are four lateral bitid saddles with

"A penciled note at the top of this page of manuscript says "Revise list." Just what changes the author wonld have macle can not. he known. but it may he inferred that lenticeratilie was dropled as an alandoned family, and that possibly coilopneentida was assigned to another sujerfanily. It in wlvious that his tonception of the grom, Nammitida had become very lifferent from that expressed by him in Zittel's Text-hook.-T. W. S. 
sulpplylliform marginal saddles and excessively short pointed marginal lobes that are landly more than serrations. The ventral lobe is very broal and livided. The first and second lateril lobes are narrow and similar to those of Buclirems, but it should be noted that the dormal sutures are muknown, and these may be quite distinet. The third lateral lobe is entire, and the fourth saddle harlly past the entire stage, exhibiting only a slightly trifid wutline. Snch sutures exhibit aftinities with the smooth primitive ancestral stock of the P'siloceratide of the Jura and other forms of Pachycampyli descended from these because of their massire broal saddles, so entirely different from the num, axecssively hanched saddles of the Phyllocampyli and Leptocampyli. I do not, of comse, mean that Mojsisoricsia is probably descended direrty from I'silorems, hut it may he a Cretacems usember of a primitive stock which began with Psiloceres in tho Jula. The intermediate forms are as yet unkumw or have not heen published. The existence of such a trunk or main branch of a primitive stock from which all of the more complex gromps are lateral offshonts has been infereal fim the ontogeny as the most probable way to account for the ontogeny of the primitive species of these gromps. 'Thus in the present instance the smonth discoidal yomng of Buchireras and other genera ran be readily accounter for if the comparison between them and the later stages of Mojsisociesia is admitted. If such a stock of prinitive forms existed, it is also easy to accomit for the maintenance of such printive smooth psiloceran-like shells in the later nepinde and sometimes in the neanc stages of Cretaceous forms Otherwise the continued renewal of these in the ontugeny at such late stages must be referred to mole aneicnt ancestors than any represented in the Jura.

\section{Morsisovicsia nutipelui Steimmanil.}

H. I, tigs. 1-3.

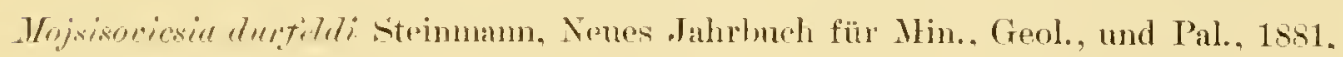
11. p. $143, y^{1 .}$. i.

The peruliar fossil deseribed under this name has a compressed discoidal shell with slight constrictions, open mubilici, and smooth surface that in extrinal aspect resembles Traneceras and also some of the discoidal Desmocontidie like P'seudophyllites Kosmat, hut las entirely different sutures. These have an aspect similar to those of Buchiceras bitobatum, but the form of the rolution differs so widely that no further comprarisons can be lisade 
with this genus. The living chamber is short, the aperture las a blunt lostrum, there are shallow sinnses on the edges of the venter, a hroad lateral rostrum on either side, and shallow sinnses between these and the mombilical shoulders, and poobably a crest on the dorsmm.

The rentral lobe is rery boad and short, with a loroar short siphonal saddle. There are three bifid lateral saddles, with an incouplete apparently entire saddle at the lino of involution. The Iobes are short and nuch marrower than the sadrles, and the entire outlines of both lobes and saddles have short obtuse marginal sadiles and narrow, short, pointed, simple marrinal lobes.

'The speries is known to me only through Steimmann's figmes, which are reprodnced an Pl. I, figs. 1-3, with the single exception of lis enlarger drawing of the side view of fig. 1.

Loculity: Pariatambo, P'eru.

Age: Albian (?).

\section{BUCHICERATIDAE Hyatt.}

It las been fomm impracticable to mite the genus Burhiceras with any known family, on aceount of its peruliar development and sutures. The approximation to the Hystatocenticla is close, so far at the earlier stages are concerned, the compressed, comparatively smooth-keeled romng in the neanic stage having consilemable lesemblance, but these similarities are lost in the subsequent derelopment, owing to the partial suppression of the costa and the very distinct sutures. The development and sutures separate these forms completely from Kumiceras. They are separablo from Tissotidae by their first lateral saddles and their ventral lobes, and from Buroisiceras, which they also resemble, by the absence at all stages of a third line of tubercles and by their sutures.

The sutures are similar to those of the disenidal smooth shell of uncertain aftinities deseribed as Mojsisovicsin by Steimmamm.

su far as known there are no representatives of this genus except in Sonth America. It shomld be remembered, lowerer, that all information lecetofore published has rome from this single fossil.

The serond genus included in this family, Roumeroceras, las sinular

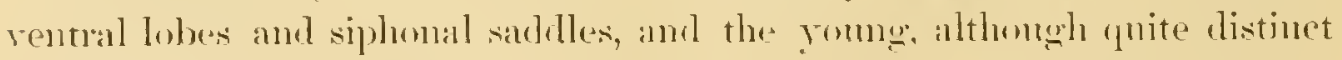
in lreing less compressed in the early stages, accuire a similar keel at a later age, and similar firm and ornaments. 


\section{BUCHICERAS Hyatt.}

This genus was formerly described hy myself as inchuding several different species that have since been separated into distinct genera, by Dourillé, Grossourre, and others, and by myself, in Zittel's Text-book of Paleontology. The affinities of Buchiceras are not, in my opinion, very close to any of the forms formerly referred to Acanthoceras as supposed by some anthorities. The sutures are quite distinet from those of any of the fanilies of Mammitida om actount of the extrandinary breadth of the second lateral siddles. The development is similar to that of some forms of Hystatoceratida and Peroniceratida in that it is at first discoidal, compressed, and smosth, then keeled, beconing costaterl and tuberculated later, and the sutures approximate more closely to those of the romb of these families perhaps than to others. Neverthelesis the ontongeny differs in that Buchiceras does not subsequently acquire prominent costex, and the keel tends to disappear instead of beconning larger with increase in size of the volutions. The nodes, on the other hand, increase in size and prominence, especially the inner low on the umbilical shoulders. The faint serrations on the kee and other ornamentation suggest aftinities with Barroisiceras, lout the sutures and the absence of a third line of lateral tubereles, which appear in some forms of Burroisiceras, are not favorable to this solution of the affinities. The same objections apply almost equally to keeled forms of the Primotropida in which the young resemble nore or less closely those of $l$. bitobatum. The dorsal sutures are very remarkable and perhaps may eventually assist in placing this genus in closer comnection with others. The prinitive first lateral saddle is retained in Buchiceras mutil a late stage, and perhaps throughout life; it is undivided, exrept by small entire marginal lobes, but it is distinetly bifiel.

Bechiceras hilobatum IIyatt.

Pl. I, figs. $t$-!!

Bueliceres bilubatum Hyatt, 1575, Proc. Boston Soc. Nat. Hist., Vol. XVII. p. 370. Buchiceres bilndutum Douvillé, 1s90, Bull. Sor. gréol. France. Bd ser.. Vol. XVIII, p. $29 t$.

The young, for the first two, and perliajs part of the third volution, must have had smooth sides and was obviously very discoidal, flat, and keelless. The aspect of this speries must have been rery similar to Mojsisovesiu. The keel comess in upon an elevated venter previons to reaching 
the diameter of $5 \mathrm{~mm}$. and is faintly sinuous during the latter part of the volution seen in Pl. I, fig. 4. These faint undulations are due to prolongations of the costre that pass between the tubereles on the ventro-lateral angles. This keel, which is a mere angle on the renter, was obviously contimous before the costa appeared and is practically continnous subsequently, owing to the minute character of the inflections. Upon the last of the outer volution at this diameter, the first of the fourth volution, the onter line of tubereles appears and is comected by costa with the imer line. 'The last are very widely separated at first and become nearer only in later stages. The larger enstre at this age are separated by single, arenate costations terminated outwarlly by minute tubereles and fading out internally about halfway across the rolution. The umbilical zomes are not differentiated from the sides. The side is evenly plano-eonvex from the keel to the line of involution and the inner, unenstated part is smooth, except where intermpted by the inner tubereles or extensions of the tubercular terminations of the larger costix. 'The tubereles and nodes are opposite, not alternate. The sutures at this age consist of two large saddles (Pl. I, fig. 9), a narrow first lateral lobe in the center of the lateral zone and a broad second lateral on the umbilical zone. The inflections are all apparently entire. In succeeding stages the lobes renain in the same position, there being but one in the center of the side between the two rows of tubercles and one on the umbilical slomlder, but as the shoulder becomes more prominent and the mubilical zone broadens, other lobes and saddles appear internally. The renter hroadens witl age, the keel becoming more obscure in consequenee of this; the sides become flat and convergent: and the umbilical shonlders broaden ont more than the venter, the increase in the mbilical zones making the umbilici very deep. The keel on the cast at this mature stage is faintly undulated, and the lateral costie, although very obsenre, closs the venter and intermpt the keel between each pair of opposing ventro-lateral nodes. These widely separated serrations in so faint on the cast that they entirely escaped my ubservation on former accasions. They in fact can be felt more easily than they can be seen. This is also the ease in the earlier stages described above. 'The inner nodes are always larger and fewer than those on the edges of the venter. The second lateral saddle remains broader than the first lateral, even when the shell is somewhat orel to mm. in dianeter. It neempies a trifte more than half of the side and encroaches on the umbilical zone (Pl. 1, ing. 8). 
The rentral lobe is rely widely open at the base and longer than the first lateral lobe. The two amos are blunt and rory small. The siphomal saddle is phenomenally short and broad, with a faint centran marginal lobe and an equally faint marginal rounded saddle on either side. The first lateral lobe is fumel shaped, broad at the base, shont and narowing rapidly to a bifid temination. The second lateral lobe is very mueh smaller and shorter, and entire at the end. The third lateral saddle is small, entire mntil a late stage, but becoming bifid later. Beyond are two small entire sackles and two corresponding lobes or what may perhaps be more accurately described as a bifid lobe and a bifid saddle.

'The first and second lateral saddles have internal ridges, but these coalesce, forming a short, flattened area along the mesal plane, which becomes deeply convex toward dorsum and venter. There are only two broad saddles and two narrow lobes on the dorsmu, and these have no comnecting rirges with the extermal saddles. 'The surfaces of the wings of the septa ale strongly inclined inward, the onter sutures being considerably in advance or orad of the immer ones. This gives a remarkably concave aspect to the wings of the septa on either side of the dorsum.

The dorsal sutures, which were worked ont with diffienlty, show that the inner arm of the hifid fourth lateral sadille passes across the line of involution, coaleseing with the thind dorsal saddle. The antisiphonal lobe is asymmetrical, entire at the top, unequally serrated on the sides, and bent over to the left mutil the tips touched the immer angles of the first pair of dorsal saddles to the right of the mesal plane of the body. The first pain' of dorsal saddles are deep and broad with broad entire bases. The first lateral lobes are snall and mequally bifid, the sirles being consely serrated. The second dorsal saddles are much inclinerl and obseurely tridentate or (entire. The second dorsal lobe is very small and entire. The third dorsal saldle is a part of the fourth lateral, as stated above, and is entire.

Vestiges of the shell were present upon this cast in a few places and showed coarse lines of growth. Unfortunately the shell covering the venter of the young wholl was chipped off in cleaning this part for drawing, and evidence of the statenent made above with reference to the keel was lost.

Locality: Cachiycu, west side of Hullagua River, l'eru.

Aye: Upper ('retaceous. 


\section{ROEMEROCERAS Hyatt.}

These shells were so similar to the type of Buchiceras in extemal aspeet that 1 formerly supposed the type of this genus to be an older stage of $B$. bilobatum, but nore prolonged arquaintance with these forms shows that they are not in the same generic group. While the bifureated costae, the large norles on the umbilical shoulders, and the nodes w the ventro-lateral angles are the same, the involution is greater, the lateral zones more compressed and broader, the umbilici narrower, the yomog have larger nodes, and the keel entirely disappens in the full-grown shells, except perhaps in R. gabbi. 'The sutures are also quite distinct, and similar to those of Tissotide in some species, but the first lateral saddles tend to develop three arms in some species and the bases of the other saddles are apt to be dentated more or less completely. The ventral lobes are similar to those of Buchiceras and entirely distinet from the broad ventrals of the Tissotiida. The same characters appear to mite Linemiceras with Roemeroceras, but the development and full-grown shell in Knemiceras, especially the invariahle presence of the concave venter, seemed to place it in closer association with the Pulchelliidie.

\section{Roemeroceras gabbi 11. sp. Hyatt.}

Pl. II, figs. 1-3.

Amemonites bitubutus Gabls. 18it. Jour. Acad. Nat. Fci. Philadelphia, 2d ser.. Vol. VIII, p. 270. pl. 38, fig. 3.

In my revision of this form I made too great allowance for the possible variations dne to age, and misled Professor Gabb in identifying this fossil with Burhiceras bilobatum. As comprared with B. bilobatum, the nodes on the umbilical shoulders are much less prominent and more numerons and nore (losely approximated, the venter has large ridges not present in bilobutum, and the flatness and proportions of the saddles are too distinct to ocem in the same species, even though allowance be made for the sutures in gubli being nearly one rolution older than those examined in $B$. bilolutum. The sutures of this species approximate more closely to those of $R$. syriaciforme than to those of any other species, but R. gabli differs in the greater number and smaller size of the nodes and coste. Fig. 3 of Gabb's plate shows the lateral aspect with an onter line of nodes lower on the sildes and a sinnous outline to the venter which does not appear 111 syriariforme, and also a 
stouter and more quadragonal volution than any other species of this genus. The originals of this species were not reexamined. 'They could not be found in the Academy's collection at the time of my risits, nor has subsequent searels, made by the kindness of P'rofesson Pilshry, bronght them to light.

Locality: Quebrada de Colpanayo, Department of Cajamara, l'eru. Age: Upuer Cretaceous.

ROEMEROCERAS SYRIACIFORNE HYatt.

Pl. 1, figs. 101-14.

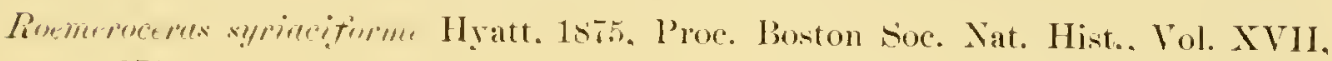
p. 371.

This species reaches a dianeter of $90 \mathrm{~mm}$. in one cast withont a living chamber. The sutures are approximated and overlap internally on the auxilinies, slowing that the gerontic stage las begun. The ormamentation and form are the same as in bitobutum. When the cast is only $29.5 \mathrm{~mm}$. in dianeter there is, however, 10 difficulty in separating this from bilobatum. 1t is more tomplessed, the sides brader, the renter narower and flatter. The sutures lave more resemblances to those of li. gabbi, but the saddles and lobes are nerer so slowt, nor truncated, the saldles being namower and the lobes homder. 'The rentral lobe and siplonal saddle are similar, but narower and less digitated. The first lateral sadeles are similan in being bifid and rather broad, but aheady at this early stage slow denticulations over the entire base. 'The first lateral lobe is similar but less decply divided, by the similar marginals. 'The second lateral sarldles are mequally bifid with bases romded or approxinately phylliform, entire, and unlike those of yablii. The seeond lateral lobes are quite broad, apically like the first laterals, but are merually quadrifid. The third lateral saddle is as broad as the secomt lateral, and also bifil. It ocempies part of the side and also part of the nubilical zone, the narginal lobe being npon the umbilical shonlder. Inside of this there is one broad bifid saddle reaching to the lobe at the line of juvohution. There are therefore four saddles at this early stalge rery like those of gubbi, extept in laving rounder bases. Later, on the same volution, this imes saddle becomes tivided into two by a median marginal lobe, and still later a small lobe makes its appeanance at the line of involution, completing the ontline of the imermost lateral saddle. There are then five satdles and six zygos lobes on eitler side. 
The oldest sutures are rery much changed, and look like those of a distinct species, but are obviously in the gerontic stage. 'The bases of the sadiles are nearer together, the entire parts of the sides much elongated. and the lobes longer and narower and the digitations situated at their apieal ends mucli deeper. 'The saddles are longer and hroader, with entire bulging sides, and the marginals not increased in mmber, but much longer and larger.

The sutures lave at this stage close similarity to the peculiar outlines attributed to Ammonites syriacus by vou Buch (fig. 1 of pl. 7 in his C̈ber. Ceratiten), but the first lateral is not so broal and does not have the minute phylliform marginals of that figure. The marginals on the first lateral saddles, and also in the first lateral lobe, are tongue shaped.

The fourth and fifth lateral saddles are entire, tongue shaped, and divided by a narrow bifid lobe. The young sutures, until a late neanic stage, lave outlines similar to those of some species of Tissotia. After this the outer saddles become completely renticulated, and again, as described above, lose a considerable part of these denticles in old age.

Fragments of the shell were present on the largest cast. None of the specimens was incrusted by any extraneous growths that could be shorm to have fastened thenselves on the surfaces of the casts.

The figure of the young in an early ephebic substage (Pl. I, fig. 12) is a very near approach to the old specimen which was crushed on one side (Pl. i, fig. 10), but of course, owing to differences of age, the nodes are larger. ${ }^{a}$ There are fifteen nodes on the rentral borler and six on the umbilical shoulders on one volution of the younger specinen, and eleren on the outer and seven on the inner row of the old specinen. The bifid costre are also present in the younger specinen, mingled with single ones, as in the old stage. The keel disappears on the last quarter of the outer volution, both on the cast and on the shell, in the young specimen, and is absent also in the older one. The young shell was seen in a section of the specimen represented by fig. 12 of $\mathrm{Pl}$. I, and although not perfect enough to figure, showed that when about of the same size as the young of $B$. bilobutum (Pl. I, figs. 5, 7), it had a similar keeled form.

Locality: Cajanarca, Peru.

Age: Upper Cretaceous. 


\section{Roemeroceras attentatim (Hyatt).}

I'l. I. fig. 15 .

Buchiceres uftemutum (paus) Hyatt. 1sis. Proe. Boston Soc. Nat. Hist., Vol. XVII, p. 372.

The cant differs from syriaciforme in having nore numerons nodes on the inner line. On the outer volution, at a diameter of $64 \mathrm{~mm}$, there are about nine on the inner row and sixteen on the onter, whereas in syriaciforme, at at dianeter of $90 \mathrm{~mm}$. there are seven on the immer line and eleven on the outer line; in another specimen of sylraciforme, at a lianeter of 73 mm., there are the same number: in amother, at a riameter of $31 \mathrm{~mm}$, there are six on the inner and fonteen on the outer line; in another, at a dianeter of 41 nm., there ane seven on the inner line and fifteen on the outer.

There are faint signs of a lieel on the trpe specimen, showing that it belongs in this genus. The general fom is much nore compresined than that of $R$. syriaciforme: the venter is narower and the lieel is also less dereloped. The volutions are more enveloping, and the mbiliens is smaller. The specinen is a cast, partly crushed on one sile and somewhat worn on the other, but although the sutures are not consequently perfect they are entirely distinct from those of other species. The first litteral hobes are bificl and shorter than the rentral lobe. Instear of being of abont the same length or longer than the ventral, as in R. syriaciforme, all the saddles are broad and very short, as are also the lobes. The first lateral saddles and lobes are completely denticulated by mallonals. The secomd lateral is trifid, the third and fourth saddles are bifid, and there is a fittl saddle, but this is on the line of involution and rery narow. The seeond lateral lobes are trifid. The third lobe is in the umbilical zone and bifid, hut otherwise entire, and the fourth is very small and apparenty entive, but too much worn to make observation certain.

There are incrusting ostreans upon both sides of this cast and they appear to have been attached to a fossil cast.

This species is foumled upon a single finssil cast, one of the two used for the description of Buchicens attematum IIyatt, but not the type. The latter is to be found on page 151, under the name of Knemiceras uttematum Hyatt.

Locality: Celendin, P'er'u.

Age: Upper Cretaceous.

yox XuIV-03-3 
Roemeroceras subilancm 11. sp. Hyatt.

Pl. II, figes. t-ti.

This specimen is a cast, whole diameter 5i mm The lateral zones are flatter than in $R$. syriaciforme and dentirulatum, and the onter nodes are smaller, more acute, and have sliglit lidges or orad continnations in some cases. The inner nodes are also smaller in the romog and increase very rapidly in size on the last volution and then suddenly disappear, the volution becoming at the same time contracted to a subquadrate ontline. There are four small and three large nodes on the inner line, the place where the fifth wode onght to he is vacant, and there are fifteen nodes on the outer line. The living chamber, which is probably very nearly complete, is less than one-half of a volution in lengtl the last two larege nodes of the inner line are on this chamber.

The sutures have very broad, short, simple saddles and vory short lobes. 'They are sinilar to those of $R$. denticulatum but have not sneh complex outlines. The last six sutures are nearer together and become finally closely approxinater, showing that the fossil is probably an outgrown shell. This cast laving been cracked open, it was possible to study exactly the contact of incmsting ostreans with the surface. It was found, as in other ases described, that no shell layers were present, the ostrean having grom directly upon the surface of a fossil cast. The shell is flresent in the impressed zone where it is protected by the enveloping volutions, and it is there thick and well defined.

Locality: Cajamarea, l'eru.

Age: Upper Cretaceors.

\section{PSEUDOTISSOTIID E Hyatt.}

If the position here taken is correct, the genera assembled under this nane are distinct from those heretofore included under the Tissotiidre They include forms fiom the discoidal channeled and keeled Psendotissotio in the Turonian to the highly involute compressed Plesintissotia of the Senonian. The lobes have the sane denticulated ontlines as in 'Tissotidix, but the saddles are more complex, being denticulated in all the genera except Plesiotissotia, in which they are all bifid, the first lateral saddles being quadrifid according to Peron's tignre. 
The retations of the genera in this family ean mly be estimater by their full-grown sledls and sutmes, and donbtless any arrangenent that can now lo male will be only provisional. So fall as the facts go, I'seudotissotiu is a flat-rentered, keeled, and chamneled form nntil a late age, losing its keel in old age and having so rose a resemblance to Tissotice tissoti that it seems to be the only fom having any alams to be comsidererl the ancestor" of that species, as first pointed out by l'orou.

Choffutireras. until a late age, has a venter with keul and channels like those of I'sendotissotia in C. meslei but combined with an inflated volution and deep, aluput umbiliai and lighty inelined, convergent sides. In other speries the line of modifications indicated by the later stages of its ontogeny leads into forms laving subacute venter's at a comparatively early age, and possibly the keeled and chameled stage with its flat venter may have altogether disappeared in some of these. The highly involute, compuressedkeelen forms of Hemitissotin follow these in the same line of modification and as their sutures also coincide and they orour in the senomian, whereas all of the above-described genera are 'Turonian, l'eron's idea that they are the dinect desecenlants of I'seudotissotin seens to be well sustained.

That these are not transitional to true Tissotiu becomes apparent when it is recognized that the type form of that gems has an motogenetic history like that of I'sendotissotice and is probably, as stated in the description of the Tiscotiulax, the most primitive member" of a series of forms distinguished by their differences of development as well as by their simpler and more retrogressive sutures.

Although the sutures differ decidedly, the forms of more primitiva species like I'sendotissotia yullimnei and their keek appear to plare them povisonally nearer to the Bucheraticle than to the keelless forms. I have lat no fossils for examination in this family, lout the literature and the figures given by (xrosinure and l'eron lare been sufticient to enable me to arange the forms provisionally and to make romments upon their probable relations that will, it is hoped, attract attention and lead those who have hetter "pportunities to test the truth of the views presented below.

\section{PSEUIOTISAOTIA I'eron.}

Peron's typical species, I's. gallienuei, is a discoidal form with keel and channels, having obviously, as observed by Peron, genetic affinities with 
true Tissotin as here defined, but it differs in the more complex untlines of the sutures, all of which lave sumall marginal lobes and sadrles. In my opinion, the genus slould be limited, so far an knwwn, to one speries, the type described he l'eron. The ofler species described muder this mome are obviously widely distinct in their forms and mole of derelopment. The sutumes resemble those of Roemeromos wh the lateral asject. The rentral lobes are also alike, so far as can be seen un Peron's figure. Peron's suggestion that these are the ancestors of Tissotiu and its allies in the Semonian appeas to be supported by the facts so far as now known. 'They appear' also to have been the immediate ancestors of Ilemitissotin and its allies in the senonian, but this last inference needs confirmation that can omly be obrained through the stmly of the yomng of the latter.

\section{P'secdotissotia gallennei (d'ophigny).}

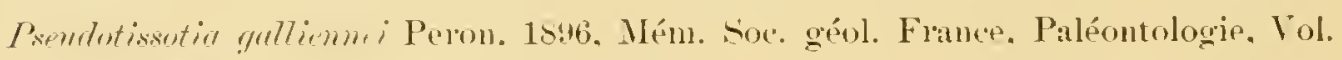
VI. No. 1\%, pl. 2. fig. 3; pl. 3. fig. 1.

'l'his is a molerately compressed but still comparatively-discuidal form, witl large unbilicus and involution enveloping something nore than we we half of the sides, according to l'eron's figures. The venter is flattened, with heary, eontimous keet and shallow channels bordered externally by thick continuous ridges. The sides have rery broad fold-like costre without tubereles. In extreme age all of these omaments disappear. The entive aspeet and genetic transfomations of this fosil are so similar to those of Tissotia tissoti that it wonld have to be inchuled in the same genus, if the sutures were nuknomin.

Loculity: Fiance.

Age: 'Tumulan.

\section{Pseithotissotia ? tunisiessis 11. sp. Hyatt.}

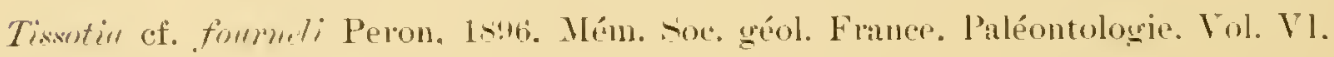

No. 17. pl. 12. figm. 7. S.

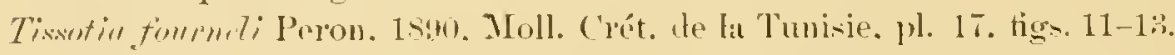

'This remalkable fragment has a trumeated renter, entire keel, and compressed rolution, with modenatuly laroe umbilicus. The costre are foldlike, with tubercles on the umbilical shomlders and a line of rosely set elongated tubereles on the rentro-litteral angles. The first lateral saddles are trifid and rither peculiar, owing to the approxinate equality of the three 
marginal saddles. The other saddles are vely long and phylliform, and according to Peron's tigures the third sadelle is trifid or bifid. These sutures and the rentral lobe, with its steep denticulated sides and truncated siphonal saddle, ane similin to the sutmes uf the uld stage of Roemeroceras syriacitorme. The form and ormanentation also agree with this determination. but the keel is more prominent than is usual in this gemon. It is possible to understand this form, if it is related to $P_{s}$. gallemei, because in that case the lieel and lateral costre ance similar to those of that species. The differences in sutures lie largely, aceording to Peron's figme, in the second lateral sardles, which ane entire. This mat le due to metrogression.

Locality: North Africa.

Age: Santonian.

CHOFEAT'ERAS 11. gent. Hyatt.

This unenus has sutures similan to those of I'sendotissotiu, but the form is distinct. The species are more a less stont gibbous forms with more or less npen and rleep unbilici. The sides are leavily costated and nudose along the umbilical shoulders, but there ane no external tubereles aceording to Peron. He also describes the venter as having a rontinuons keel and two ventro-lateral ridges. The form is more involute and more compressed than Psendotisotiu, and the outer parts ut the volutions lave a tendence to berone concave in the involute species with broad rolutions.

The type is C. meslei (Peron).

\section{Choffaticeras barjonai (Clioffat).}

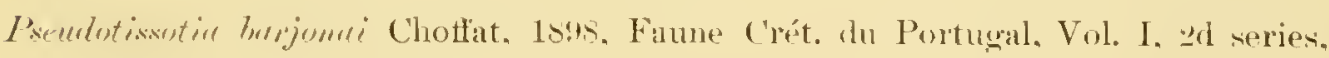
1). 1s, fig. 3: pl. 2.2. figs 40-t².

This species is a close ally of C'. mestei uf North Africa, as has heen stated by C'hoffat, but las a nume forminent keel and has no signs of chammels on the venter.

Lorelity: Pontusal.

Aly" Turonian.

\section{('hoffatrikas mestei (Pelon).}

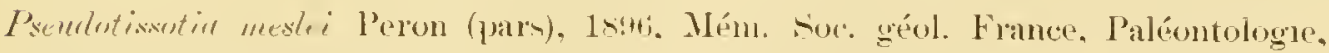

Vol. VI. No. 17. 11. 1. tig. 1: pl. ‥ fig. 1 (net pl. 2. fig. 22. nor pl. 2, tig. 22).

This species has a form which is sublenticular when seen from the front in l'eron's figure, owing to the great prominenoe of the mubilical 
shoulders and the rapid slope of the lateral zones aurl subacute chanacter of the venter. The costere are linear and only slightly eurved in the unly well-preserved part of his type as figured. The involution covers about three-fifths of the next inner whorl, learing a rather large open umbilicus showing the youmger whorls.

The more discoidal form (pl. 2, fig. 2, and pl. 3, fig. 2) supposed to belong to this species, is certainly distinct spereificilly and may be nearen to Pseutotissotia than to any species of this genus, but it is too imperfect to give diagnostic cliaracter's.

Loculity: North Atrier.

Age: Thronian.

Chopfaticleras? nouvillei (l'eron).

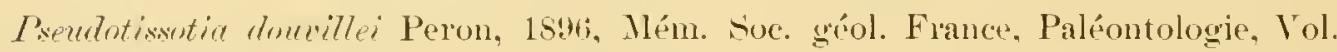

Y'1, No. 17. pl. 2, figs. t, 5, and pl. 3. figs. 3, t.

This speeies, as figmed and described by Peron, has the general form and aspeet of C.mestei, but the leary nodes on the umbilical shoulders and dirhotomous wate reaching to the sides of the prominent keel are onite different.

Locality: Nortl Africa.

Aye: Turonian.

\section{Henitissotia Peron.}

This genus seems to me to be more intimately related to Choffaticeras than to Tissotia and other genera laving similar forms but having sutures with smonth saddles. Such questions can only be definitely settled when the younger stages become known. These involnte and more or less compressed forms with trenchant keeled venters are apparently in the direct line of modifientions indieated lo the sinilar forms of Tissotide, but on the other hand their sutures correlate with the more complex outlines of those of l'semetotissotia and Choffaticeras, and this indicates that they are simply parallel as representative forms analogons to some of the Tissotide but really in the genetic line of Choffaticeras. They have retrogressive characters in the undivided outlines of their imer satdles, but this arrest of development his not affected the outer saddles that are completely digitated. 'l'hey ean not be placed anywhere in the genetic line between Psendotissotin and Subtissotin an aceomit of the absence of dhimnels and 
ridges on either side of the keel, and this is the only position that cond be claimed for them in riew of their peculiar sutures. All of their chanaters accord best with the riew that they are direct descendants of Choffaticeras. There is an interesting group of this or an allied genus from the Senonian, described by Chotfat in his Céphalopodes de la Fame Crétacique du l'ortugal, Tol. I, 2d series, but the condition of the specimens did not permit him to describe them sufticiently to judge elosely of their aftinities.

\section{Henitissotia CAZINI l'erom.}

Hemitissotin cuzini Peron, 18:47. Mém. soc. ugéol. France, Paléontologie, Vol. VII. No 1\%, pl. 14, fig's. 1-5: pl. 18, tigs. 9. 1\%.

This species is a highly involnte compressed form, and in the oldest specimen figured the first and second lateral satdles are completely denticulated, the third is equally divided by a median marginal lobe in the figmre of the suture of the oldest specimen (pl. 18, fig. 9), but this is not described in the text.

Locality: Nortlı Africa.

Aye: Senonian.

\section{Memitissotia? Batnensis Perom.}

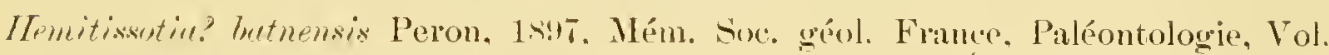
VII. No. 17. pl. 15, higs. 7, s.

This species luts the external aspect of this peculiar gromp and the sutures are similar as figured hy Peron, but his question mark after the generic name is justified by the Sphenorliscus-like aspect of the first latera] siddles.

Locality: Nortli Africa.

Age: Senonian.

\section{Henitissotia morreni (Coquand).}

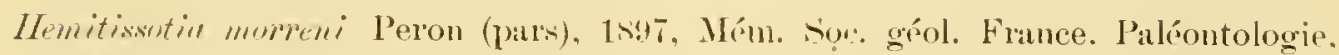

Vol. V1l. No. 1T, pl. 15, figs. 1 and 2 only, and pl. 1s. tig. 11.

Ilemitiswotice moreni vall. prace imu, ibid., p. 77.

This var. precifue of Peron is a highly complessed form with acatte renter. Pl. 15, fig. 8, may be the young of this species, and if so, it show conclusively that it is distinct forn the tollowing.

Loculity: Nortl Africa.

Age: Senonian. 


\section{Henitissotia tissotiaformis Peron.}

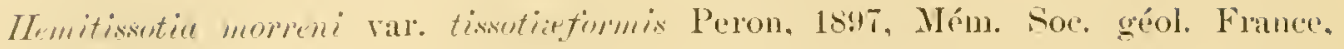

Paléontologie, Vol. VII, No. 17. pl. 15, figs. 3-5 only.

This is a much stouter form with stouter volutions, and as might be expected in such a species the young exhibits distinct ribs. Hemitissotin moreni ral: coquandi (pl. 15, fig. 6) nay be distinct, but no firont riew is given and the sutures shown in pl. 18, fig. 14, do not appear to be rery different.

Locality: North Africa.

Age: Renomian.

\section{IIEMITISSOTIA D.IELFFiNSIS (l'ereni).}

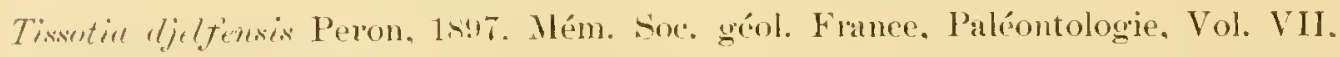
ㄱ.. 17 , pl. 16, tigs. ?. t.

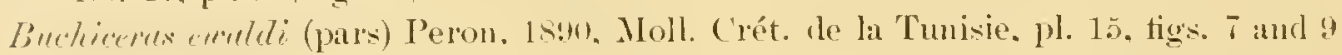
(no other's).

This is a compressed shell rery closely allied to I'aratissotia ficheri in aspect, but differing in the sutures. These have the first lateral saddles namow and bifid as in Memitissotia and the first lateral lobe is large as in that grenus. The figure of the highly compressed cast given by Peron as pant of his earde in the Mollusques Crétacé de la Tunisie has very sinilar. sutures so far as the deep division of the first lateral saddles and lobes is concerned. It is better to quote it liere, since it is moloubtedly not related to the other species (m the same plate and has also a form similar to that of rjelfensis.

Lorclity: North Africa.

Age: Lower Senonian.

\section{Henitissotia ceanueroessis Choffat.}

Hemitiswetiu cudomroensis Chotfit. 18:s, Faune Crét. du Portugal. Vol I. 2d series. pl. 211. tigs. $7-10$.

'This species is apparenty a nember of this gems and is of interest in sluwing the old-age transfomations, the romnding of the venter and contraction of the outer rolution. If the last pant of the last rolution is berfectly natural, it shows an extrandinary senile scaphitoid deviation from the spiral.

Locality: Portugal.

Ane: Senonian. 


\section{PLESIOTISSOTLA P'erm.}

This genus has been foumled by Peron entirely upon the difterences of the sntures at eompaned with Hemitissntiu. The first lateral sirblles are hoad and rery deeply divided br a median matrinal bobe and eateh arm is phylliform and is also subdivided by a median marginal lobe: the remaining sodrlles are plyylliform and equally sublivided by median mancrinal lobes. It is a question whether these peculiar sutures really represent another sroup or are simply retrogressive modifications in the genetiv line of Hemitissotia. 'The compressenl and costaterl form does not indicate affinities, lunt, as stated by Peron, the divided saddles are similar to those of Hemitissotia precimua, except the first laterals, which are marrow and inregular in cutline in the latter.

l'Lesiotisgota MiChaleti P'orm.

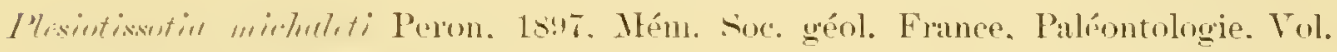
VII. No. 17. 1, 16. tigs. 7. .

I highly compresserl keeled form with asta having tuberdes on the umbilinal shoulders, as in some speeces of Hemitissotia. The sutures are describer in the notice of the genus.

Lorrelity: North Atrical.

Aye: Senonian.

\section{TISSOTIIDA Hyatt.}

This family name is lere mucl nelrowerl in its applieation as compared witl what it was in my chapter on Cephaloponla in Zittel's Text-hork. It is now considered applicable to a series of grenera that includes only Tissotia and its immediate allies, excluding Pulchellia, P'silotissotin and Lopholobites. The gentral can be described as latring keeled forms, with elannels only in prinitive genera. The keels have a crenulated or nodose stage in a number of prinitive goncra, hut are continuous in the flattened forms. Coste are present in the globose primitive forms and are usually tuberoulated, and when they disappear the nodes are apt to persist. The venteris lose their keels and buenme loumded ar flattened in old age. One gomms has a hollow keel (Paratissotia) and other's may have lullow kects. So far, howerer, the mly fact in farm of this is the presence of prominent keels on the shells that have 10 indesponding keel elevations on the casts. The sutures are 
charateristic, having simply digitated on plyyliform, often entire or bitid saddles and narrow, often club-shaped, lobes digitated at their tops.

The first lateral saddles are usually bifid, but in some forms they become trificl. In these cuses the alditional saddles are added on the ventral sicle though the division of the onter arm of the first lateral sardlle. The gromp ats here defined is confined to the Lower senonian in Europe, and the Soutl Ameriman representatives are probably of about the same age.

TISSOTLA Domvilké.

The definitions leretofore given of this genus lave been based upon the sutures which, according to the views here advancerl, can not be accepted when not correlatable with external characters. The type of this gemus, T. tissoti, so far as can be seen from the side view given by bayle and the front view by Douville, is mique in haring a considerably inflated form like some species of Subtissotia, but with keel and ventral chamnels bordered by contimons ridges, and in the extreme gerontic substage a truncated venter without either keed or chamnels. This certainly justifies the "pinions of Grossmure that this species is closely related to Psendotissotia galliennei. Accombing to the views lere advocated, this genus is a direct derivative of galliennei of the 'T'uronian, an has been previously suggested by Perm.

\section{Tissotia tissoti (bave).}

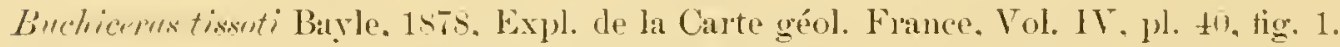

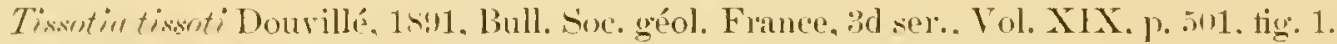
Tissut in tiswoti? Peron. 1s97, Mém. Soce géol. France, Paléontologie, Vol. VII No. 17.

pl. 1․ tig. 3.

The type of Bayle's species, which is also the type of lis genus Tissotin, has been figured by linn in side view and by Douvillé in fromt. from the same type in the Feole des Mines, Paris. Dutrille alsu describes the specimen. It is therefore plain that it is a stout form without any rery markerl nodes and is flat on the renter in its gementic stage, having lost its keel on the last pert of the onter whlution andording to bayle's figme, which is natural size, and also bonville"s tigure. This shell also, according to Douville's figure, preserves an unusually depressed renter haring keel and shallow chameds on either side bordered by faint ridges or carine througlont the adult stage. The low of the keet is correlated with loss of the gibhosity of the sides, these becoming flatter and more convergent mitwinlly. 
SUB'ISSOTIA 11. gen. Hratt.

This group inclutes a number of the species heretofore associated with Tissotia tissoti on accomnt of the sutures. These are unquestionably sinilar in the simplicity of their ontines, but, as has been argued above, this fact can not he considered as determinative in such peculiar retrogressive groups, unless correlatable with other characteristics and especially with the changes in the development both of the yommg and the gerontic stage.

'The younger stages, so far as known, begimning with the neanic stage, have, as a rule, very globose forms with continmous keels, the sides are costated and terminate outwolly, with tubereles that form raised but discontinuous ridges on either sirle of the keel. The venter is mucls broader than the area includerl within these lines of nodes, except in the gerontic stage, when it narrows down to the sane limits as are common in Metutissotir. The keel disappears in the gerontic stage and the lateral coste and the nodes also in some species, according to Peron's tigmes, leaving the renter more ar less rounded.

Type is subtissotin inflate (Peron).

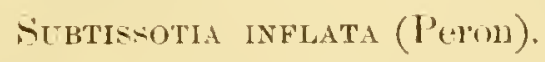

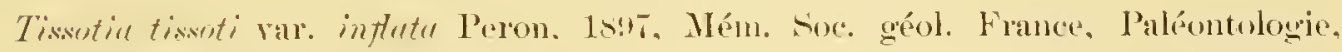
Vol. VII. No. 17. pl. 1․, fig. ti.

The figures of this form, given by Peron, show an excessively stont shell, increasing rapidly in transverse dimeters by growth, with an obtusely subacute renter, prominent keel, and slight chamels on either side, bordered by ridges. Peron's figure at diameter of $68.5 \mathrm{~mm}$, is $51 \mathrm{~mm}$, while the figure of intermedia, which is $12 \mathrm{~mm}$. in diameter, is $53 \mathrm{~mm}$., only $3 \mathrm{~mm}$. wider than the much smaller and yommer specinen of infleta. Such differences of proportion do not arem in the same species of Ammonites.

Locality: North Africu.

Ayp: Batse of Senomian.

\section{Subtisitotia intermeda (l'erom).}

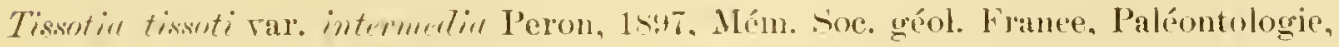

Vol. VII, No, 17, pl. 12, figs. 4, 5.

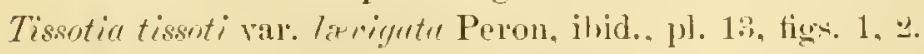

This form differs from inflata in having nuteh less gibbous rolutions at the same age and a more acute renter at all stages. 
Locality: Northern Africa.

Alge: Lower senonian.

Suitissoth 1Pkoxi 11. sp. Hyatt.

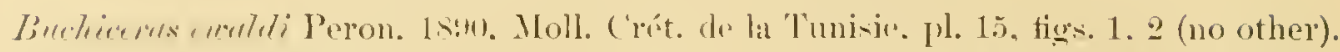

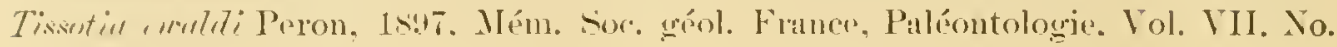

17. p. 163.

This is hased on a speciment from Thunis, of a dianneter of $107 \mathrm{~mm}$. It is figured hy Perm as having an entire leeel throughout, although the rounderl tubercles on wither side of the rentro-lateral angles lave almost disappeared at a stage when in his mothi rall afriound they would have become elongated and rery conase and the keel have been resolved into elongated tuhercles. The venter is also entirely distinct in this species, in its sharper wutline and more prominent keet. These features are also associated with preculiar sutures. The sutures of Tissotic reficene loare a long, well-defined rentral lohe, the sides of the first laterals being alorupt, whereas in this fossil there is a very short, ill-defined ventral lobe, with the sides of first lateral saddles leutionlaterl am sloping. The first lateral sarddes are deeply divided in T. afirinana, while in this the division is not so well marked. The resemblances in form and sutures between this and T. Irreigutu show that they are closely related.

Lorelity: North Afriea.

Age: Base of Senouian.

\section{Nubtisigta africana (Perom).}

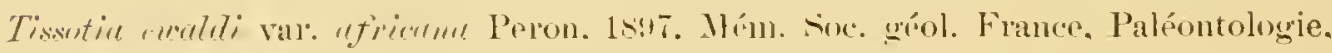

Vol. VII. No. 17, pl. 11. figen. 1-ti.

At a diameter of $5 t$ mm. the ymug tigmed by Perou is a very giblums form, in which the broalest dianeter of the last volution measures about $39 \mathrm{~mm}$. The keel is continnoms and prominent even on this cast, and there is a lins of prominent tubercles on either sirle along the vertro-lateral angles. In the aged specimen, figmed at rlianeter of 105 1mm., these have become elongated, and the siles bejug less gibbous the venter is flatter, and on this volution the keel begins to clistppen, becoming resolverl into elongated nomes. There ane no costie fignred on these casts. Peron considers this irlentical with Tissotia robini. as figured by Grossonve, hut robini 
is a costated compuessed species with a continums ked, even in extreme age, after the disapleandrance of the lines of tubereles, arcording to firnssouvre's figure. His erraldi is sinilarly figmeed as a compuresserl shell, but not in

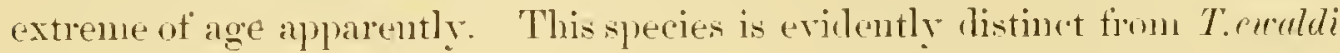
figured by Perom in his Molluspues Crétacés dre la Tmisie, which attains a laree size, and at an alvinued ago still has an entire keel and romded tubercles. The resemblance of the young of this species to the more matme stages of Subtissotia inflatn and intermedia is appanent, if Grossonve is comert in his assigmment of the sublles casts figured to this species.

Locelity: North Ifricar.

Aye: Lower Renomian.

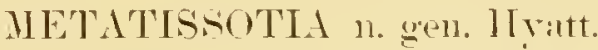

Following ont the system alopted in these pages, it hecomes obrions that spereses laving the peculiar development of Metatissotia foumeli and robini can not be assuclated with either Tissotin or Sulfissotiu. The entire ontugeny, incluling the gerontic stage, of these highly compuessed forms is distinet from Tissotia and Subtissotia on the one side and from the more acceleraterl ilevelopment of I'aratissotia on the other:

The typical ontogeny begins with a stage having a compressed smooth form and a continuous keel. In the mext stage thore is a morem less trmmrated renter having also a continums keel, hut with nodes at the termination of costiu that appear om the siles, and nodes also on the mulilical shonlders. In the geroutic stage, the costax, keel, and ehandels finally displean, leaving the sides smontl ol ornamenterl wily with lare nodes, and the venter more (1) less angular.

\section{Mécatissotia fotranel (liayle).}

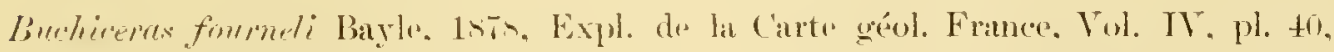
fig. ? (not tig. t).

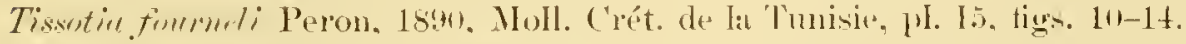

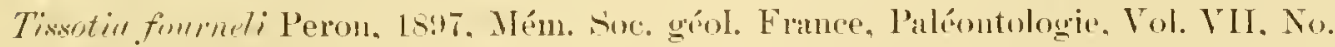
17. 1). II!.

The development has been reterminerl by l'eron in his Ammonites de l'Algriere, eited above. In the figures of his rumerest specimen, which measures about $30 \mathrm{~mm}$. in dianeter, thele are large dichotomous costat with alternating slort single costre. In the oldest part of this speeimen and in 
the stage represented by the next figme, the forks of the dichotomms rostre aro becoming obsolete and heing resolved into short costae, so that there are two slunt molose costac between the larger ones. 'This is obviously, lowever, very irregular, since in the figured specimen, which has a diameter of 8.) mm., there is still one diehotomous costation. It is obvioms, too, that the contie, being very leavy, berome fold-like witl awe. 'The longere costae have modes on the muter ends along the ventro-lateral angles, and modes along the monbilinal shoulders, whieh persist throughout the ephebie stage and are present as very broal, low folds in the gerontic stage. Aceording to Peron's description and figures, the short costre disappear and are alpurent only as simple nomles in large specimens.

This is a compressed form of this genus having an entire keel at an early stage, and a close ally of the Eurnpean speries $M$. nolosa. Perom has clearly shown that Bayle confommled two species meler this nane, but I doubt whether Bayle's Tissotia fommeli. figs. 4-5 of pl. 40, is idnutionl witl excellit.

Loculity: Nortlı Africal.

Atge: Base of Senonian.

Metatissutia robini (Thiollière).

Ammonites mbini Thiollièr, 18ts, Anu. Soe. dAgriculture de Lyon, Vol. XI. pl 1.

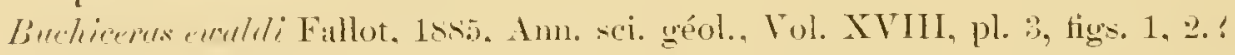

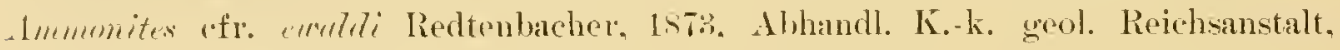
Vol. V. pl. 쁘. figss. 5 a-i.

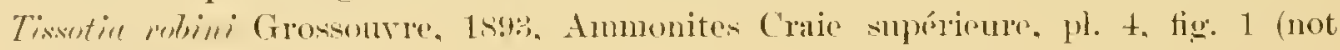
fig. :

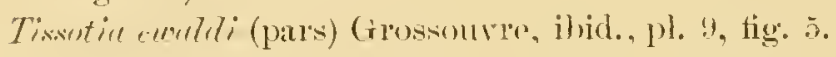

This shell has a compressed form, and the adult figured hy (rossoure at a diameter of abunt 50 mm. has a truncated venter witl prominent elongated tubereles on the ventro-lateral angles and a prominent continuous ketel. At the end of this volution, or say at a diameter of 55 mm., according to Crosisoure's figures, these tubereles begin to disappear, and at a diameter of $80 \mathrm{~mm}$. they are absent, and the venter has consequently lost. its trunc:uter aspect and become subacute. This agrees also with Redtenbaclier's figure of at specimen which is $83 \mathrm{~mm}$. in liameter, and in which 
the old-age characteristics are similar. Crossonve's fig. 2, alsu named robini, is apparently a distinet species. It has the subacute venter of the oldest gerontio substage of true robini when only 5.9 mm. in diameter, and this begins when the shell was abont $40 \mathrm{~mm}$. in diameter or earlier, according to this figure. 'This whole volution is also corered by dichotomomis costet having only very faint tubereles. This miglt be a dwart of this species. but is apparently not a young specinen. Redtenbicher's figmes (except perlaps 5, f and h) all appear to belong to this species, and fig. of may have been a worn specimen wr a dwarf. At any rate, the latter has a suture with the first lateral saddles Jooking remarlsably like an immatme stage of those characteristic of robini. Grossonve thinks this is the true evaldi of Buch, but on the contrary it seems to me more likely that purt of his encaldi as given above belonges to robini. 'The peenian ventral trend of

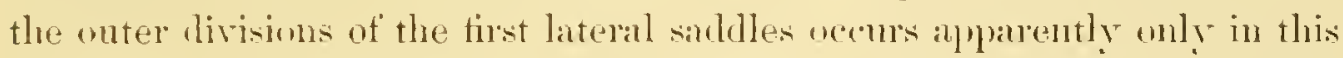
species, Rerltenbacher's figures are of value in that they give information with regard to the young, showing that at a dianeter of abont $18 \mathrm{~mm}$. the keel is prominent and continuous, as it is in later stages, the costic are well developerl and dichotomons and have two rows of tubereles, one on each mmbilical shoukles and a bow on either side of the keel. It is also to be noted that the venter of this yomg specimen is more arote and the whole form mole compressed than in the nome mature stages.

Leculity: France amel Austria.

Age: Selnmian.

Metatisntata rodosa 11. sp. Hyatt.

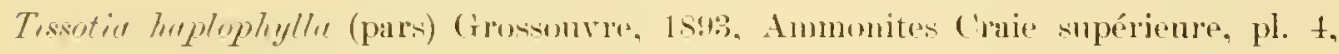
figs. 3. + (not tig. 5).

The two specimens figured by Grossonve lave large nodes on the umbilical shoulders like those of haplophylla, but the contac are well dereloped at an age when these are absent in true haplophyllu, as shown in Redtenbacher's figure. 'The keel at the same stage is entire, whereas in haplopleylla there is a row of tubercles.

Loculity: France.

Age: Coniacinn. 
Metatissotia haplopimbla (Redtenbacher).

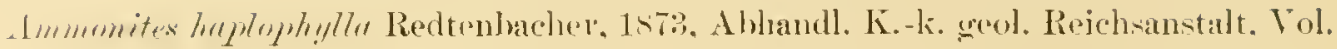
V. pl. 23.

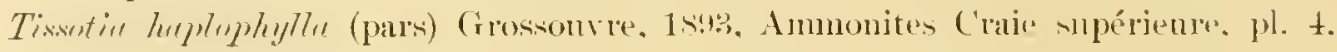
fig. 5) (not figs. 3. 4).

This form is eompressed, but has heary fold-like costie and rery stout nodes on the umbilinal shoulder and ventolateral angles. the venter being similar to that of $\boldsymbol{M}$. fourneli, hut with a line of nodes instearl of a continuons keel. The French fossil quoted above naly possibly be the same, but it has quite a distinct aspect, and the supposition of Grossunve that the sutures will prove to be similar when those of the Iustrian specinen are better known, is not sustained hy the collateral evidence. Grossmure's figs. 3 and 4 of the supposed neanic stage of bis hrulophylln are certainly quite distinct, laving an entive keel and aspect allied closely to Metatissotia formeli and robini and here treated as distinct under the name of Meta. norlosu.

Locality: Austria.

Age: Senonian.

\section{Metatissotia fwald (rom Buch).}

Ammomites ingliti ron Buch. Ahhandl. K. Akad. Wiss. zn Berlin. 18t5. pl. 6. figs. 6. 7. Tisentin emaldi (pars) Grossonre. 1s93. Ammonites Crair supérieure. pl. t. hig. 6 (not pl. 9. tig. 5).

This speries is very sinilar to Metu. robini, lut, so far as known by the figmes of Crossonve and others, these two species appear to be distinct in their sutures. Both species lave the first lateral saddles deeply divided and the outer arms of these are shorter than the inner ones, but the ontlines of these outer arms in this speeies are rounded, ply vliform, undivided, and straight or parallel with the keel. In robini these onter ams are inclined toward the keel and the ontlines are subdivided by marginal lobes in mature specimens.

Locality: France.

Aye: Senomian. 


\section{Metatiscotia altessensis (Peron).}

Tissotic auressensis Peron. 18:17, Mém. Soc. géol. France. Paléontologie, Vol. V1l. No. 17 pl. 13. tigs. 4. 5.

This is a cast of what is apparently an old shell. The form is not mulike that of Paratissotia grossonver, with a similar large umbilicus, and it might be considered as perhaps the gerontic stage of this species, but the sutures are so distmet that this smpposition is not temable. These have extrandinarily large and long phylliform saddles, and the first lateral saddle las a conspicuously trifid base.

Locality: North Africa.

Aye: Senonian.

METATISsotia SLIZEWIC\%i (Fallot).

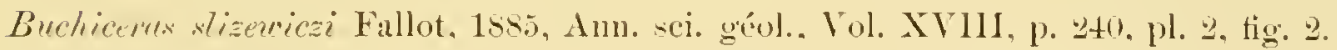
Tissotid slizeminzi Grossonvere. 1s93. Ammonitus Craie supépieure. p. th, fig. 25: fl. T. fig. 2.

'This species, if correctly given by Grossourre, has a young form which at a diameter of 41 mm. has a truncated renter, contimous keel, a line of small tubercles along ach rentro-lateral angle begiming on the last rolution at about this size, and also a line of nodes on the umbilical shoulders. 'The form at this stage is like that of Tissotiu ef. fourneli Perom. The sutures ane also similar in having trifid first lateral saddles and other saddles and lobes long and large. The three marginal saddles and lobes are much nure completely dereloped, longer, and the first lateral saddles broarler in consequence of this differentiation of the outlines. The norles on both lines are much larger in the larges shell figured and the keel persists. The umbilicus is also of gom size, as in the species of l'eron refereel to above. Peron considers all of these forms to have ocenred in the semonian, and his evidence is vory strong on this point.

Locality: France.

Age: C'oniacian, hase of Senonian.

HON XLIY-013-4 


\section{PARATISSOTIA n. gen. Hyat.}

llighly compressed smonth forms like the tyene of this genus, I'. regularis and firhewri, omit the characteristic muluse stages and none or lesis obtuse ar flattened kieled renters of Metatissotir or else pass through then at an early stage, becoming later highly acute and snowth or at least without pominent nodes in their mature stages. In the two species examined they never have ronmeled renters at any stage. The discovery of a lnilow keel in the latel stages of $I^{\prime}$. reguluris would have caused me to sepalate that species from the other speries referred to this group lad their derelopment heen different and the structure of their keels also known.

\section{Paratimotia grossoterei (P'erom).}

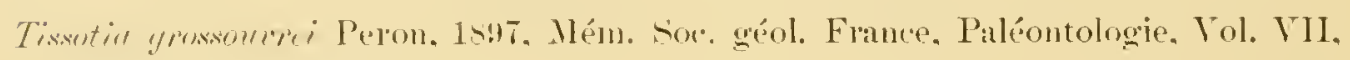

No. 17. pl. 11. Hiws. 1. 2.

'This is sintal in aspect to I' fichemri, but is less involute, the umbilicus being much largel and the sutures distinct. The first lateral saddles have dentirulated intlines instear of the smonth, phylliform arms of $I$ '. ficheari. The young have not heen exmmined, lut the adult appears to belong to this gentws.

Locolity: North Ifrica.

Age: Lower śenminum.

\section{Paratissotia? thomasi (Perom).}

Tissutic thrmusi Peron. 18:17. Mém. Soc. géol. France, Paléontologie, Vol. VII, No. 17. pl. 13. fig. $\therefore$ (not pl. 16. tigs. 5. 6).

The type of this fom is a compressed shell with rey involute whorls and the zone around the unbilicus depressenl and Hattened. The venter, at least in advanced age, las a simple, not very prominent keel, maccompanied by tubercles of any kind and sides almost smooth.

The form is not sufficiently well known to be placed lere without a query after the generic name.

Loculity: North Africa.

Aye: Jase of Semonian. 


\section{Paratissotia ficheuri (Crossouvie).}

Tissotiu fichenti Grossouvre. 1893. Ammonites Craie -mpérienre, p. 35. fig. 17.

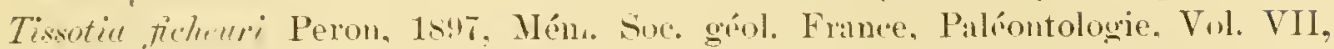
No. 17, pl. 1丷., figs. 1. 2; pl. 1s, tig. ㄹ.

Buchicences emeldi (pars) Pelon. 1s!ro. Moll. Crét. de la Tunisir, pl. 15, figss. 3-6.

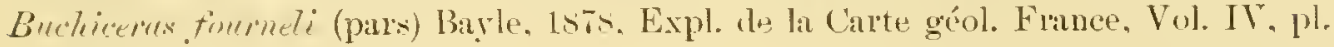
to. figs. 2 and 4 (not tig. 3 ).

This is a rerr much compressed shell, with no "hamnels on either sicle and no tubereles on the coste, which ane simple and very slightly developed. The keet is prominent and arote, and the umbilicus is very small. The custe are shown by l'erm in the side views of a young specimen laving a dianeter of $55 \mathrm{~mm}$. and in a rery old shell with diameter excreding $115 \mathrm{~mm}$. In both the astere are linear and straight, with only the outer half developed. A description of this last specimen, which is evidently very old, would have been of murh interest, but it is not wiven. The very broal, lum denticulated sardle occupying the extremity of the ventral lobe and the deeply divided denticulated first lateral sardles of this species, of which the cuter one is bifid and the imner lats a broad, phylliform base, are rery peenlian, as are also the costia. The rery globose fossil figured on pl. 15, fig. 8, by Perm in his Mollusques C'rétacés de la 'Tmisie as part of his Burhiceras encaldi is mudoubtedly a distinct species, but the information given is ton limiterl to enable one to refer it to any known species. The reference of part of $B$. found Bayle to this species is given on the anthomity of Grossonrre. Bayle's tigures are handsome, but not rery instructive.

Loculity: Nortl Ifrica.

Age: Base of senonian.

Paratissotia serrata (Hyatt).

Pl. II, tigs. 7-11.

Buchiceres serratem (parr) Hratt. 1575, Proc. Boston Soc. Nat. Hist., Vol. XVII, p. 370.

This is a fragmentary cast of more than one-half of an entire coil, without living chamber. The diameter without the shell is $37 \mathrm{~mm}$. The outer volution measures $20 \mathrm{~mm}$. at larger end, the umbilicns $4 \mathrm{~mm}$., and opposite 
side of onter rolution from line of involution to venter is $17 \mathrm{~mm}$. The shell reduces the dianeter of the umbilius to $3 \mathrm{~mm}$.

The cast of the outer volution is perfect only on one side. This is planoconvex and covered with regularly arrangerl costre, of which there are eight to half of a volution on the imner part of the whorl. The eosta broaden and flatten outwindly, becoming sigmoidal in curvature and then bifurcate, the branches bending well forward and rising into elongated swellings on the cast. These are about $3 \mathrm{~mm}$. from the onter adge of the keel, and there are very slight obsolescent ridges beyond them, which, however, do not cross the smooth bands on either side of the keel.

'The renter on the first part of the onter volution, the third quarter, is subarante, but on the last quarter it is beginning to be rounded, the keel laving disappeared. This shows that the shell was in the gerontic stage, and the approximation of the last two sutures also indicates the same stage. 'There is also the trace of a line, probably a line of involution, impressed upon this part of the outer volution, showing that the living chamber must lave decreased very rapidly in the amonut of involution, since it did not cover quite half of the sides wn the third quarter and part of the fourth quarter of the now exposed volution. The length of the absent living chamber could not be determined, hut that it was much rounded and depressed on the venter and in an extreme stage of gerontic degeneration is highly probable. The sutures are more like those of I'aratissotia founcti, as figured by Grossonrre in his Ammonites de la C'raie supérienre. The rentral lobe is, however, very short, broad, and opens widely, with two small, short, entive arms. 'The siphonal saddle is hroad, prominent, and entire, with a hardly pereeptible nedian narginal lobe or depression, rhich seems inclined to disappear in the gerontic stage. The first lateral saddle is large, as in other species of this group. On the third quarter of the exposed volution it is plainly only one bifid saddle, but on the fourth quarter the dividing marginal is deeper, and there appear to be two distinct saldles, as in I'. atjelfensis. The outer arm of the saddle show' a hardly perceptible median marginal, as in P. foumeli. There are five other lateral saldles, all entire, and, like the first lateral, rely short and extrenely broarl like those of P. fichenri, as figured hy Comsomve.

The first lateral lobe is loroad at the end and dentienlated exactly as in Tissotiu tissoti and Metatissotiu curaldi as figmed hy Lonville, but it is rery short and broad. The second laterals are suliller and also denticulated. 
The remaining lateral lobes are like those of the sane species, but very much narrower, and the seend to the fifth hardly more than mere indentations.

The dorsal sutures were seen only from above. The antisiphonal lobe was obvionsly rery narow at the base, but its lengtl conld not be detemined. There arre seven pairs of entire zygons dorsal lobes and saddles, the latter mucl narrower thin the external laterals. The first and second lateral saddles are comnected across the septum by broad ridges, so that the septum observed was convex externally and internally along the mesal plane, but concave along the center. 'The saddles on the dorsmu and the corresponding externil saddles were comnected only by very slight ridges, and the intermediate surface of the septum was convex.

The figures of sections show the broad globose, keelless form of the nepionic stages and perhaps of the earlient of the neanic stages. The siphuncle is certainly rery small and the keel is solid when it first appears, as slown in figne. The disappearance of the siplunele left me in donbt with reference to its structure in later stages.

Locality: Carhiyaru, west side of Huallagna River, l'eru.

Age: [p]er Cretaceons, probably Senonian.

$$
\text { Paratissotia regularis 11. sp. Hyatt. }
$$

Pl. 111.. figes. 1-ti.

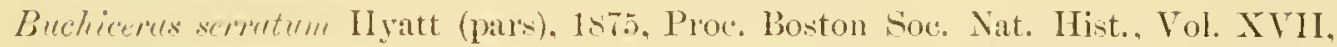
p. $3 \pi 11$.

'This species has a broad rolution with a romded venter' until the shell

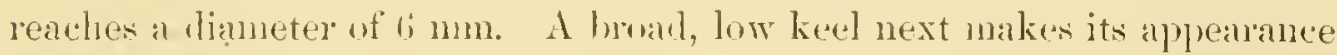
and the next volution becomes lechet-shaperl in section. There is certainly one line of noles on the umbilical shoulders at this tine, and the mmbilical zone is bond and at an angle of about $45^{\circ}$ with the line of involution. 'This helmet-shapen section, with nore or less gibbous sides. is retained through life, but hecomes more compressed; the keel becomes subacute and prominent, and slight eoncave zones appear on either sille of it. An oriter line of tubercles appears on the elges of the elevated renter, and both lines inclease steadily in size. The umbilical zone becomes rombled and is in the first ephebic substage at roht angles to the plane of roiling. The two lines of tuberres are comnected in the ephebic stage, 
and possibly earlier, by faint custe, which bend forward onto the venter but do not cross the keel. These were observed on the ast alone, no shell being present on the parts observerl.

The yomg were seen only in section, and the nepionir stage was rompletely destroyed, so that the earliest part actually seen was probably in the ananeanic stage. The sutures were developed on the ephebic rolution, and there is no close similarity to those of any described species of this genus. They have a siphonal saddle, and first lateral sardles on both sides more like those of Hemitissotin djelfensis Peron than any uther. The inner arm of this sadtle is, howerer, bifurcated instead of being entire, and the outer arm is trifurcate instead of being bifurcate as in that species. The siphonal sartle has an inner rounded marginal like that so common in sphenodiscus. There are five pairs of entire saddles on the sides, inside of the first pair. The lubes more than the saddles are like those of Peron's species, but they are more symmetrical in outline and longer and narrower in proportion. It is interesting, however, to note that its nearest aftine in form is also an African species, Paratissotia mpossonerei of Peron. This is close enmol in external aspect to have been considered identical but for the sutnees, which are quite different. P'eron's form also appears to have had at solicl keel. The surfaces of the septa and the dorsal sutures differ from those of I'aratissotin serrata in that there are only four broad zyogous saddles and lubes on the dorsum, and the saddiles are directly connected with the external saddles by broad ridges that flex the floor of the septa correspondingly. The internal wings of the septa are also straight. The antisiphonal lobe, so far as seen, seems to be mnch broater than in that species.

The young must lave been sinnilar to that of Paratissotia serrate in form, and keelless until the neanic stage was reached. The keel was at first solid and then became hollow.

Locelity: Cachiyanen, Perme.

Age: Upper Cretacems, probably Senonian.

\section{Incertae sedis.}

Tresotia cossoni Peion.

Tissotin mosmi Peron. 1s9). Moll. Crét. de la Tunisie, pl. 16, figss. 1. 2.

This is a large fossil, $248 \mathrm{~mm}$. in diameter, with acute renter exactly similar to Sphenorliscus in aspect and evidently extremely aned, as shown by 
the overlapping of the last sutmes. These have low, lomal, entire saddles and broal lobes, rery different from an observed in that genus. 'The rounger sutures resemble those of Tissotic more nearly than those of Sphenotiscus, the saddles being phylliform and entire. The ventral lohes as figured are quite different from those of any describerl species, so far as I know. How much of these peculiarities an be attributed to the metamorphoses of age remains unknown, but these rental hoses lise apparently no siphonal saddles except a minute point that seems to he becoming obsolete. Unluckily this inportant point is not mentioned in the deseription.

Locality: Bir Oum-el-Djof.

Age: Campanian.

Tissotia globosa 11. spr. Hyatt.

Tissotice thomessi Peron (pars), 1s90, Moll. Crét. de la Tunisie, pl. 16, figs 5. 6 (not pl. 13. fig. 3).

This fossil, figured on pl. 16 by Peron, las a glohose form with distinct proportions from the type of thomasi, and the umbilical shoulders are quite prominent. The sutures also are distinct according to the figure given. The aspect indicates aftinity with Metatissotia rather than Purrtissotia.

Locality: North Africa.

Age: Semonian.

\section{HETERGTISSOTIA Peron.}

If the type of this genus hat been abrated so as to round off the venter, its sutures would lare placed it near Tissotin, if not in the same genns. Nevertheless the flattened renter with keel, and the bitureated, fold-like costre ending in slight tubercles (m the edges of the smootli ventral zone and gathered into a few large nodes on the prominent mubilical shoulders are similar to those of sereral species usually incheder in Pulchelliu. The aftinities of this fossil appear to be indeteminable without some knowlectge of the young

\section{Heterotissotia NeOCERATITES P'Hom.}

Ileterotissotiu neoceratites Peron. 15:T. Mém. Sioc. géol. France. Paléontologie. Vol. VII, No. 17, pl, 14, figs. 9. 10.

Sufficiently described above, except that it is an involute compressed form with flat lateral zones and small but not very small umbilicus. The 
involution covers up entirely the sides of the last volution, but it is obvions that until a late stage preceding this, it is not so complete, leaving a large and more open umbilicus in the young.

Lorclity: North Africa.

Age: Senonian.

\section{SPHENODISCIDA.}

This is a provisional group to include genera having three principal lateral lobes and saddles and numerous anxiliary lobes and saddles which are more distinctly phylliform than is nsual in the Tissotidie, also having keeled renters.

There are three genera: Indoccras, Libycoceras, and Sphenodiscus. The development of the first and second genera, and whether they lave a solid keel, is not known, but the third has an acnte venter from an early stage and has also a solid keel. Nearly all specimens having hollow keels exhibit a truncated aspect on the venter of their internal casts which is not shown in any figmes of Indoceras and Libycoceras

\section{INDOCERAS Noetling.}

Indoceras has been placed in the Sphenodiscide near to Libycoceras hecaune of the external characteristic's of the later stages of the type species described below, and because the sutures in both the species described by Noetling have resemblances to those of Sphenodiscus. As in many other published forms, there is no description of the earlier stages, and the dorsal sutures, which would also greatly assist in drawing correct inferences, are still nnknuwn. The essential distinction between this and Sphenodiscus lies wholly in the fact that the saddles are entire in this genus instead of being sivided or denticulated as in the former.

\section{Indoreras balucinstanense Noetling.}

Indocems beluchistancnsis Noetling. 1s!r. Pal. Indica, Series XVI. Vol. I, pt. 3. pl. 221, tig. 2: pl. 22. tigs. 1-3.

According to Noetling's figures and descriptions, this interesting species at a diameter of about $40 \mathrm{~mm}$. las elongated forward-bent ridges on the nuter part of the rolution that are obviously the remmants of sigmoidal coste. The venter at this stage is somewhat obtuse, but tending toward being subacute, with a keel bordered by smooth zones and whscure ridges 
on either side In later stages the renter hecomes planoeonvex, the keel and lateral rirlges having disappeared. These characteristics are very similar to those of Smenodiscus pleurisepta. The sutures have entire phylliform saddles that resemble those of Sphenoliscus more than thuse of 'Tissotide. The first lateral saddles are described by Noetling as being bifid in this species, and as becoming split up into separate saddles during development. There appear to be three principal lateral saldles in the fullorown.

Locality: Mazar Drik.

Age: Upper Senomian.

INDUCERas acutodorsatum (Noetling).

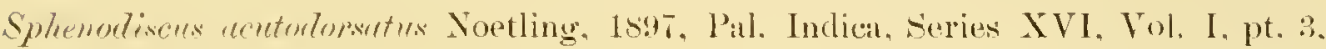
pl. $\stackrel{2}{2}$, fig. 3.

This shell has the usual acute volutions of syphodiscus, but the sutures have thic entire sarllles of Indoceras. In fact the only distinction appears to be that the first pair of saddles are not yet completely separaterl, but appear to be branches of a first lateral. It might be said, therefore, that this species had only two principal lateral saddles, the first and second, the furst heing deeply bifid. If we reckon the sutures as laving three entire principal lateral saddles, two of which are not yet fully separated, the spercies passes into Intoceras.

\section{LIBYCOCERAS Hyatt.}

This genus is fommled upon a single species, which has, howerer, such a'peculiar combination of chararters that it am not be ineorporated with other genera. Zittel recognizes the aftinity of this form to smbermoliscus and descrilses it as having three principal lateral saldles. 'The sutures have phylliforn entire sadules and simply digitated lobes, and resemble thone of the yommen of S. lenticularis after they have passed throngh the stage in which both saddles and lober are entire. The median lateral line of tubercles and lnoad costax romnecting these with an onter line of nodes along the erlge of the venter and distinct keel are, however, quite different tiom the tubercles and costre and solid ancute venter of sphenotiscus, which has distinct sutures, and also different form ludoceres, which has similar slltures. 


\section{Libicoceras ismaele (Zittel).}

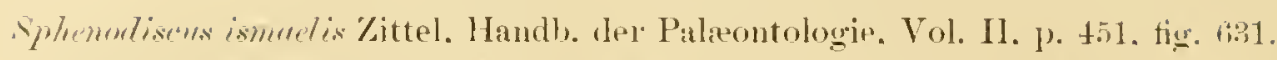

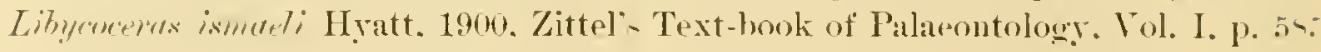

Acoording to Zittel this has three principal lobes and saddles.

Loculity: Libyan Desert.

Age: Cpper Senonian.

\section{SPHENOIDISCLS Meek.}

This genus is apparently a close ally of Emgnoceras, judging by it sutmes and external characters, hut the development shows it to be very listinct. In two species, plemisepta and lenticularis, the young were examined, and in these there were no indications of a stage having a flat or concave renter. In the nepionic stage the species is romded on the renter which in the neaniv elanges directly to a form with an acute renter and flattened side like that of the adult. There are thee principal lateral sadnles derived form the division of the primitive first lateral saddle.

Tho earliest stage deseribed in S. lenticularis exhibits sutures like those of the adult of Neolobites, but they are also very similar to those of some species of Euyonoceres having longer, narower, and more phylliform saddles than usual, like Engonoreras suljectum. There is, howerer, in Emyonarems and in Veololites also a very distinct persistent tirst lateral. These puculiarities in development of the sutures, as well as the acute venter, heighten the resemblances to the shell figmed by Zittel as s. ismuetis. This is generionlly distinut and here described as Libycocems, but sphenodiscus might be a moditied form of the same series in which the keel had become incorporated with the venter and with more complex sutures, whereas its derelopment does not indicate descent from any of the genera having flat and tuberculated venters. The external chancters of this genus are often so miform that the sutures as a loule are the only means of distinguishing the species. The exceptions to this rule are to be found in the American forms s. plemiseptu, and perhaps acutum, and the European representative of the former, S. binclihorsti, which have lines of tubercles and fant coste. The keel is solid, and the siphuncle being placed well within the sutures of the siphonal satdles. is protected by a ridge of the stony filling of the camerax ant is not, therefore, easily laid bare when the shell is removed firom casts. 


\section{Sphenodiscls pledrisepta (Commal).}

Pl. III, tigs. 7-15: Pl. IV: Pl. V. tigs. 1-3: Pl. Vl. tig. 6.

Ammonites plenrixetu Conrad. 1s5., U. S. and Mex. Bound. Surr., Vol. I. Pt. II, p. 151. pl. 15, tigs. 1. a, h, c.

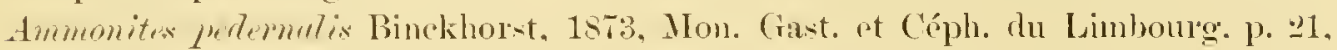
Pl. $V \mathrm{a}^{1}$. fig. 1 (no others).

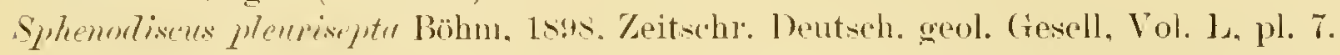

Conral's original specimens, preserved in the United States National Musenm, show hum erroneons and misleading are lis deseriptions and figures. The original of his figure las two distinet mows of lateral tuberes. Another specimen, $117 \mathrm{~mm}$. in diameter, is the one cited as collected by Schott, "Tellow stome." This has the same characteristics, but is in the gerontic stage. and the unter low of tubeleles disappears on the last quarter of the outer volution. The comlition of the specimen, however, made this somewhat doubttul

A number of fine specimens were collected by Stanton and Vanghan near Eagle Pass, 'lex. All of these lave two rows of nodes on the sides, and one is a noble specinen $182 \mathrm{~mm}$. in dianeter (Pl. IV, fig. 1-2). What appears to be the abrated edge of the aperture is present on one side, and the living ehamber is sonewhat orel une-halt of a rolntion in length. The inner row of nomles is present, but the nute low is replaced on the last rolution in the gerontic stage by brad ancuate folds. These ane visible thonghout the volution on the side opposite to the one figured. The renter broadens and becomes less acute on the thind puarter of the onter rolution and is rounded on the last quarter. It is obvious fiom this that the specimens described below were in some cases dwarts, the range being considerable.

The interesting fact in this lange sperimen is that the lobes and saddles rary but slighty fiom those of smaller fossils. The three principal saddles and the lobes are longer; there may be ne or two saddles more, making the total number fourteen, concealed under the shell of the unbilical zone; and the marginals are more numerons, but otherwise the sutures are just about the same as at younger stages. There are only fire divided saddles, the first to the fifth, as in younger stages, and the remainder are entire. Another fact is that the amount of involution decreases so slightly, even in 
this large speeimen, that it is hardly perceptible. There is, howerer, a brouder unbilical zone in the paragerontie substage and a decider umbilical shoulder.

A small east of this species, No. 19145b, U. S. National Iusemm (1'l. 11I, tig. 14), only 59 mm. in dianeter, shows the ephebic stage. The dianeter of last volution from line of involution to venter on cast is $32 \mathrm{~mm}$., the sune dianeter on opposite part of volution is $22 \mathrm{~mm}$, the unbilicus being 5 mm. without the shell. 'The fragments of the shell are not specially thick except on the crest of the venter, where it forms a solid keel, and in the umbilicus, where it is over a millineter in thickness.

This cast is somewhat compressed, but judging fom an accompanying older specimen it is a medium stout rolution with, howerer, a very acute venter. "There are two lines of distinet, transversely elongated, radiating nodes, about $8 \mathrm{~mm}$. apart, the outer line oceupying the centran surface, about $7 \mathrm{~mm}$. from the venter. The inneg line gradually incrases its distance from the umbilical shoulder, but on the first part of the onter rolution begins to be farther semoved from the dorsm than the onter row is from the renter. The renter is blunted on the last part of the cerposed rolution and the parephebic substage had probably already begun in this specimen.

The ventral saddle is that of Sphenorliscus, with similar maroinal saddles at the inner corners, hut the aspect of the lobes and saddles is like those of older specimens, except that they are shorter and the sutures do not overlap anywhere, and lo not exen approach one another until near the umbilical shoulders. The lohes all have flaring tops and the saddles phrlliform and rather broad bascs, flattening ont, howerel, as ustal near the umbilial shonlders. Nevertheless, on the umbilical zone they are again slender and phylliform.

The first lateral saddles are trifid, narow at the openings, with a few phyllitorm saddles; the seemd and third are bifid a trifle longer, but of nearly the same form; the third becomes tritid on the oldest part of this rolution; the fourth is tritid and then hecomes quadrifid. These form a bent wutline, each heing a little longer than its neighbor, beginning with the first lateral. The fiftl is bifid and from thence to the mubilicus there is the usnal row of entire saddles gradually shontening up and slowing more and more prinitive forms; but they become namower again on the unbilical zone. 
The branches of the rentral lobe are trifid and spreading as usual, but small, of course, in such a suture; the first laterals are shorter and broader and together with the longer second and third laterals form the usual arch. The fourth lateral is about half the length of the third and from this to the umbilicus there is the usual diminishing row. The trpe is bifid except the first and fourth laterals; these were uncertain. All are diviled except, perhaps, the last and umbilical lobes: these were not seen.

There are twelve saddles and twelve lobes visible, and there may he a sadile on the line of involution on the left side; the sutures of the right side were not seen.

The older specimen of this species (PI. III, fig. 13) is a cast from same locality and is very instructive. It is $90 \mathrm{~mm}$. in diameter and the form is better preserved, not having been injured by pressure. The oldest part is $47 \mathrm{~mm}$. in dianeter. the mubilicus withont the shell is about $8 \mathrm{~mm}$., and the rolution opposite is $35 \mathrm{~mm}$. measuring from line of involution to venter. The greatest transverse diameter is carried farther out than the centran surface at this age and is $21 \mathrm{~mm}$. hetween the tubercles, the greatest dianeter opposite between tubercles and alout centran of the lateral zones is $16 \mathrm{~mm}$. No shell is present in any of these measurements.

The shell is excessively thick on the umbilical zones and is nearly a millimeter thick on the sides in the parephebie substage; it is considerably thickes on the venter, where it forms a solid keel. There are two lines of tubercles as in the smaller specimen, the age of the first part of this rolntion being the same as the age of the last part of exposed volution in the rounger specimen, but the nodes are rounder or hardly perceptibly elongated. The inner line of nodes persists and retains its distance from the mubilicus, but the noles are slightly nearer to the venter on the last part becanse of the gerontic decrease in the rate of growth of the dorsoventral dianeter. 'The onter tubercles gradually decrease and disappear, but the fold-like short costre between the tubercles persist. These coste may have a bifureated aspect when slightly hetter developerl than in these sperimens. The onter part of the whorl is leciderlly convex, while the surface between the inner line and the mbilical sloulder is decidedly concare and the umbilical zone narrow and alnupt.

The earliest part of this volution has the venter bluntly acute, showing it to be in the parephebic substage, while on the second quarter the rounding of the venter and loss of tubercles shows anagerontic substage. 
On the thind quanter folds take the place of tubercles of outer row, and on the formth guarter the venter hecomes gadually romuled. This shitts the greatest transterse dimmeter fimm the central jouts of the sides to nearer the renter. There is alsor a rery slight dearease in the amomo of involution intermally.

The living chamber is mbly in part preserved. The yommger sutures are like those of the same age in the smaller specinen, hut are a trithe more complex in outline and the rentril bohe seened to be shorter. This last, however, eonld not be made out clearly anywhere. The general chander of the sutures is the same as in the youmger specines, so far as all of the remaining lobes and saddles are concernod, and there are five divided sadrlles. The first and scrond lateral satdles are probably bifirl, in the young becoming trifid latel" and perhaps bifid again in extreme age." The thind is trifid, becoming quadrifid later. The fourth is trifid throughout. 'The rentander are same as in rounger specimen. Lobes appear to be about the same an in that specimen. The last two sutures are so close together that the overlap more or less thoughout, and the thirt suture approaches neares to the recond than in somger parts of this volution. This specimen had, therefore, in all its characters probably completerl its cycle of development and was in the paragerontic substage. There are constantly five divided saddles on hoth sirles uf specimens of this species so far as seen hy me.

A perfect cast (1'l. 1II, figrs. 7-12), labeled Rio P'ecos, in collection of Columbia University, is $60 \mathrm{~mm}$. in diameter. The outer volution measures $32 \mathrm{~mm}$, transverse diameter is 13 mm., the mmbilicus 3.5 mm., the opposite 24.5 mul., and the transwerse dimeter between tubereles of inner rom 9 mn. The outer volution has alrearly begun to show a blunted or rumded venter, and the two rows of elungated nomles are more distinct than in other specimens described. These also berin to become romded on the last part of the outer volution. "This is as much altered in the form of the rulution (i. e., renter is as bhunt) at this size as a second specinen from same locality (Pl. III, fig. 1 (suture), and Pl. V, fig. 3) at diameter of $86 \mathrm{~mm}$

"The emdition of the sutures of the paragerontic stage mate this obsersation somewhat dombthl. hecanse when slightly worn away the saldlus lowe their secomlary divisions and hecome biticl, the central marginal lobe heing always more perwistent on arount of it: greater fenetration into the interior than the more recently accuirect marginal lobes om either sile of it.

$b$ see Mr. Stanton's note, p. 6.5 . 
The first specimen is the anly one with perfect young that I have seen, and is, theretore, a rery instructive example (l'l. IIl, tigs. 9-12). In anduepionic stage the immermost volution next to the lange protoconch is romuled and followed by a volution still in the nepromic stage. This acquires an elevated renter and hecomes more compressed and helmet shaped, but has nowhere a Hattened or concave venter. 'The sutures vere simpler than those of later age. The sutures on both sicles had five divided saddles. The first lateril saddles were bifid on both sides, the second just begimning to be quarlrifid, the third and fourth symmetrically tritid, and the fifth mly hifid on the right: whereas on the left sille the second to the fiftl, like the first, were all bifid. The rulutions in section were similar in muthe to the allult, having the same highly involute and almost pearshaped section and acute venters. Neither of these specimens showed the living rhamber.

Gue sperinen (Loc. 58:, U. S. Gent. Survey, Pl. I', figs. 1, 2), when comprarel with more typical forms, shows, in what is probably the metephebie substage, the anter fold-like costae as in the gerontic stage of others. The diameter of the cast, without the shell, is about $118 \mathrm{~mm}$, partly estimaterl. The last of the outer volution measures 60.5 mm., the umbilicus. 8 mul., and the opposite rolution from line of involution to renter measures about $49.5 \mathrm{~mm}$.

The acuteness of the renter alecreases on last part of this volution, but does not hecome blunted and runded as it does at the corresponding size in the tripical forms.

The sutures of the last five septa show gradual appoximation, and in the closer approach of the last two there are indications that the specimen was begimning its gemntic stage. The living chamber was broken away, but the marks of the unbilical parts showed that this had extemed at least one-tounth of a rolution tarther on the sides. The inner line of tubercles was becoming wider apart, and together with the venter and sutures, also indicated that the gremtic stage was begm or was about to begin, and had been perhaps nearly completed in the now absent living chanber. The sutmes, it will be muderstool, always represent a later stage than the parts of the shell on the inner surfice of which they are fouml. The sutures have short phylliform siddles and broad lobes, and are well separated from each other and approximate only near the umbilical shoulders. They were 
more perfect on the side opposite to the one figured. The first lateral saddles are trifid, the second, third, fourth, and fifth are bifid and phylliform; the remainder are similar to those of the imner columms of otlier's of this species, but are perlaps snmewhat simpler in outlines. T'le exact number was not ascertained. On a fragnent of what appeared to be the same species from the same locality, there were thirteen saddles at a diameter of $60 \mathrm{~mm}$. from line of involution to venter. This was a cast, and slightly abraded on the venter. The rentral saddles were much worn and the first lateral saddles were entire, except for a faint median marginal in two sutures. The remaining lobes and saddles exactly agreed with those of the ephebic stage of the first specimen described, except in being a trifle longer'. 'There were five divided saddles, as in other specimens.

One of the fignres of Amm. pedernalis given by Bincklinst in the monograph quoted above was taken from a Texas specimen supposed to be irlentical with von Buch's species. The specimen was in the II usem of Stutgart, and was said to have come from Rio Bravo lel Norte. Texas, and to have been collected by Schott. This figure is inlentical witl the larger rarieties of this species which retain the acute venter until a late stage of development. This same specimen was refigured by bïhm, as above quoted, and properly named by lim. Except in being somemliat older and large, it is identical with the fossil figured on P'. III, fig. 15 (septum), and Pl. V, fig. 3. The first lateral saddles are, howevel, bifid, the second trifirl. the third to fifth bifid, whereas all the saddles in sutures on Pl. III are bifid, and this loolds in all the sutures on this volution in this fossil. Even in the close approximation of the sutures this is similar to Biilnm's figure and also in the war in which the inner line of nodes trend outward on the latter part of the volution.

A fragment in the collection of Frederick Bramn, of Brooklyn, N. Y., is labeled as from rotten limestone grit, Brooksville, Noxubee County, Miss. The diameter of side is $55 \mathrm{~mm}$. The imner line of nodes still remains somewhat elongated; the outer line is superseded by broad folds. The fine surface of this cast shows that the shell liad sigmoidal, and sometmes dichotomous, costee and ridges on the outer convex lalf of the rolution, but that it was smooth and decidedly concave on the mner half. The first lateral saddles were trifid, then four bifid and nine entire. There were ten enture dorsal saddles at the same age, with hobes like those of the exposed 
sides. Tnluckily the antisiphonal lobe was not exposed by excaration, and therefore it was not considered necessary to draw these curves. This species is very instructive, since its external characteristics are well marked and they show that the amomut of involution, the gencral ontlines of the lobes and satdldse, and the number of divided saddles remain very constant, while the trifid or bifid outlines of the larger sadilles are variable. 'These minor details of the saddles, and of the lobes also, depend on the relative growtl of marginals and may rary at different stages of growth or on the opposite sides in some individuals or in different individuals. 'The number of septa may also greatly rary, thes in Böhn's and the fossil figured on Pls. $11 \mathrm{I}$ and $T^{\top}$ they are $5 \mathrm{~mm}$. apalt near the center: in Braun's they are $9 \mathrm{~mm}$. distant at abont the same age and the sadelles are much longer.

Another specimen from the same collection is given on Pl. VI, fig. 6, and this although closely associated with S. lobatus, and apparently at first sight the young of that species, has all the external characters and the sutures of pleuriseptu. 'The fossilization is in the peculian' yellow limestone, witl -iron incrustations of the specimens of lohatus from the same locality. It is of comse pussible that this specinen may be the young of lobatus, which I have never seen of as small size, but in any case it is identical with ple arisplta of the same age, which has an acute renter on the outer volution and sutures like those of Pl. III, fig. 15. There are five hifid saddles on the right side at the point where that side is about $30 \mathrm{~mm}$. broad, and on the left side, where $20 \mathrm{~mm}$. broad, the fifth saddle slows the faintest possible heginning of a median marginal division.

Locality: Near Laredo, Rio Peros, and near Eagle Pass, Tex.: Brooksville, Noxubee County, Miss.a

Age: Eagle Pass beds, Upper Cretaceous.

"The following note was contributed by Mr. Stanton:

"It is pretty well establishet] that Conral's specimens were not collected near Laredo. It is probable that they came from the neighborhool of Eagle l'ass, where the species is abundant. It has been collecter] by Geological survey parties from localities from $1 \frac{1}{2}$ to $18 \frac{1}{2}$ miles southeast of Eagle Pass,

"I doubt whether the species has been fomm on the Rio l'ecos. There are certainly nu beds that could have yielded it near the mosuth of that stream."

MON XLIV-US- 


\section{Sphixonscus lobatus ('llumey).}

Pl. VI, figs. 1. 2: I'l. VIl, figs 1. 2: Pl. IX, figs. 11-1:

Ammonites lodutu Tuoney. 1856. Proc. Acad. Nat. Aci. Philadelphia. Vol. VII, p. 16is.

The description given by Tuomey of his dmm. lobuta may of course apply to another speries, but this is the only one I have seen to which the following worls could have applied, and it comes from the same state althomgh tiom another county: "Shell discoidal, smooth, thin toward the circumference;" "rlorsal (rentral) lohe fincly serrate." These worts and his reference to the large bilober saddles ats characteristic scems to make this name applicable to this species, which is so widely different from Sphenodisens lenticularis and its nearest afthes that no disenssion is necessary.

A fine specinen (Pl. VI, figs. 1, 2) in Coll. Nat. Museum, labeled S. lenticularis, No. 20577, from Ripler group, Lander's mill, 'Tippah County, Miss, is $111 \mathrm{~mm}$. in dianeter. The last volution at what appears to be the aperture measures $59 \mathrm{~mm}$. and the volution immediately opposite in same diameter from line of involution to venter is $46 \mathrm{~mm}$. The greatest transverse dianeter is about the middle of the lateral zone and is 21.5 mm. and for the smaller part of the rolution $15.5 \mathrm{~mm}$. The cast is naked except a fiagment that shows that it did not have a very thick shell. 'The imer' volutions are not entirely covered and the umbilicus is larger proportionally than in the large specinen, snpposed to be the adult uf the same species, from Pontotoc Connty, Miss. There are obseme fold-like costa indicated ontside of the greatest transverse diameter, which is nealy eentral: intermally the surface is slightly conconve. There are no mubilical shoulders and no flat nmbilical zone and the umbilical openines are shallow. 'The shell must have been very thek between the volutions and mav have much contracted the opening of the mubilicns. 'There were twelve lobes and thirteen saddles on the oldest part of the volution. The flat siphonal saddle lias a minute saddle in the center and a comple of inflections or marenimal lobes on either side of this and then at the ends two small round saddles. The rentral lobe is rery broad and the two arms also broad and obsemety tribloate, each bohe heing subdividerl by a minute sadlle. The first, secomel, and thind lobes ane broad at top and have an muequal number of small short branches, as if they were terived from the trifid type. 'They are all pohably, hmwerer, lerived from a bifid type, unless exception may be male for the branches of the rentral lobe. 
The remaining lobes have one large median saddle and an equal number of small lobes as if derived from the bifid y ye There is a series fom a prinitive bifid lobe, the eleventh, and only the twelfth lobe is single. On the right side the twelfth lobe is on the line of involuton, whereas on the left side that line is ocempied ly a sadille. The lobes are rery short and broad.

The first six saddles have broarl phylliform bases and the first five are bifid on both sides, being expally divided by a small median lohe, the sixth is transitional and entire: the remaining sadlles are of the same ty pe but so short and broad that they appear to be Hattened at the base, and in finct are alporoximations to that type.

The most remarkable fact about this cast is what appears to the the living chamber. The evidenes of the existence of a pertert living chamber on this cast seem undeniable and tlue is every mark of an aperture with an entire reflected lip. And what is still mere renarkable, the last four sutures on the left side are shortened as if absorbed by pressure after they had been built. The fompth las lost the theer inner rows of lobes and saddlles, the thind has lost seven, and the eighth saddlo is partly gone; the second has only four saddles left and faint tracos of fifth lateral lohe and ontel side of the saddle, and the basal septum is represented by hardly pereptible traces of first, second, and third lateral sadelles, no ventral ar any othes lobes.

On the right side the pressmre ot the lody has shortened up five of the sutures. The fifth has lost all the inner chitire saddles and their lobes except onc-lialf of the lant onter ame, the sixth row from the mmbilieus and the seventh from the venter. The fomth has lost this romaning halt and part of the next sadnle, the thiml has not been absonbed quite so far and has the sixtl saddle form the venter and part of the next inner lobe, the second has first four lobes and sadnles, but only one-half of the suture of the fifth satlle The traleing's of the sutures of the basal septum are slighter than om the other side and inchules as on that side only the faintest possible trates of the bises of the first thee siddles. The interval between the fifth suture on the right sicle, the last perfect one, and the alphatent aperture on the line of involution is anly $4 \mathrm{~mm}$. The interval between the same and the halt absorber sixth saddle (fom the venter) of the second suture is only $4 \mathrm{~mm}$. The rostrum of the aperture is incomplete, 
but the distance from the last rentral siphonal satdle to the broken edge is $22 \mathrm{~mm} .^{a}$ The almost obsolescent traces of sutures of the basal septum are conly about 5 to $7 \mathrm{~mm}$. from the edge of the aperture on the sides, and may have been abut $26-30 \mathrm{~mm}$. from the end of the completed rustrmm on the renter.

The only explanation that I $\mathrm{am}$ ahle to suggest is that the animal lost the power to build shell after it had constructed this apelture, hut still continued to live and build the sutures until finally the pressure of the hase upon the last sutures put a stop to their construction near the lines of involution, but allowed it to go on with decreasing completeness externally. This obliges whe to suppose that a futile attempt wats made to construct the muter three saddles and lobes of the basal septmin, and that the animal slipperl back upon the second septum after failing to do this. There are no lines connecting the broken sutures with each other that I conld detect. The reflected rim of the cast of the aperture near the umbilicus in some measure supports the opinion that the animal, failing in having a proper shell wall to the living chamber, spreal out laterally and the reflected extensions of the aperture were built by the lateral parts of the body wall that bulger out on eitler side. In that case the animal might have had an abmomally thin-shellerl living chanber which was destroyed after its death. The questions that such suggestions create ane far more difficult than I can answer with merely a single cast in hand, and an entirely satisfactory solution must be relegated to future investigations.

A large cast (Pl. VIl, figs. 1, 2; 1'l.1X, tig. 13) in Coll. Nat. Mnsem, No 24(1)3, fiom Pontotor County, Miss., is sonewhat oree $265 \mathrm{~mm}$. in dianeter. The diancter of outer volution from line of involution to venter at the beginning of last quarter wher" renter was romplete is 136 mm.: same

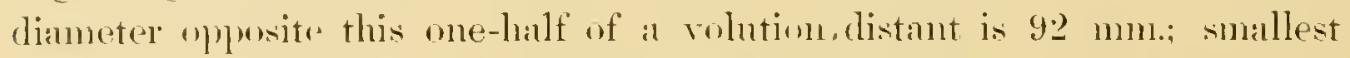
diameter 7 !) nm., one-quarter of a rolution younger than the last.

The transerse diameter through the center of sides correspmeling to first diameter is $57 \mathrm{~mm}$. and for second $3 ! \mathrm{n}$ mm.: the thind could not be measured. The right sicle is a little worn away, so that these transverse dianeters ane less than they should bee.

"These sutures ane not like the imperfect septa oreurring in Bathmorrus and some Orthoreratites, since in these cases the animal still continuent to have a distinct living ebamber. They are in some neasure similar to thase occurring rarely in very old shells. 
The form, surface, ete, are the same as in smaller specimen above described. 'The sutures, howerer, being much more mature, are quite distinct in detaik of ontline, althomgh the general aspects were similar. The saddles have the swollen phyllifom ontlines of the bases and the lobes the sime spreading tops. The first and second lateral saddles on the romngest part of the onter volution are trificl, the third, fompth, amd fifth are bifid, the remander are entire and rombled, becoming gradually flattened and more depressed toward the lines of invohtion. This was on the side figmed, but on the right side there are six colmms of divided sardlles, the sixth having only, howerer, a very small median maroinal. 'The first lateral on this side is bifid, the secomd trifid, and the four other divided saddles are bifid. The first, second, and third lateral lobes present irregularities that obscure their origin, hut are probably from the trifid type: the remainder are all distinetly bifid. There are abont fonrteen sadrles heyond the fomtl, and probably two lows more on the morer part of same rolntion, since the spiral arangement is well maked and the slarp umbilical sides are transformed into flat zones on the last half of this rolution. The saddles and lobes are more complicated and the first more deeply undercut near the end of this volution, but there is no other marked difference produced by the development of the shell, except that the saddles are all markedly longer in proportion am more slender. 'The rotmul, plivlliform aspect of the bases of the saddles is naintained because of the slow development of the diriding marginal saddles. The sutures are easily reparable exeept near the umbilicus. The rentral is a trifle longer than the first bateral, and there is a descent from the last to the third lateral, and beyoud this a deciderl break owing to the sudden decrease in the fourth lateral, which is mly one-half the length of the thirl lateral. The remaining lobes and saddles slowly decrease in length. The differences between the thind and fomth laterals decrease in the older prats of this volution and the sutures approxinate somewhat, showing the approach of old age. The tragment figured by Whitfield ${ }^{a}$ may perhaps be a specimen of this species (1) some relited form. Such broal internal saddles and digitate short lobes oceur in lobutus. They are simpler in ontline although belonging to a larger specinen than that here described as variety beecheri. There are two very large specimens in Aneriean Musenm of Natural llistory in New York 
City. One las no living chamber, but is 290 mm. in diameter. This when complete must have been much laroer than the secomd, which is over $362 \mathrm{~mm}$. in dimeter. The living chamber was probably conuplete and was about one-half of a volution in length. The shell existed near the venter and showed a completely romeded renter; the first half of this outer volution was still obtusely subacute, the tendency to roundness being present only on the last half. Hardy pereeptible broad low folds, like those of smaller specinens, exist on the sides of the outer rolution of both these fossils. The sutures are more complex than in rounger specimens, but still have about the same elomgated phyllifom marginals. There is also in the Academy of Natural sciences in Philadelphia a large fragnent of this species having smootl sides, hut the specinen was not in hand for my final revision. The concaro-convex sides of the easts of this speries and the broarl onter forward curred folds are similar to the older stages of S. plemiseptu, but no tubercles were observed. 'The youmg, so far as I know, lave not been described.

A very interesting variation from Buncombe lills, Pontotoc County, Miss.; in the collection of Frederick Braun, of Brooklyn, X. I., is shown on Pl. 1X, fig. 11. This has on the right side sutmes quite different from those of other specimens figured. The diameter is about $155 \mathrm{~mm}$. and the breadtl of the side where suture is shown in Pl. IX, fig. 11, is about $85 \mathrm{~mm}$. 'The first three saddles of the left side are given on 1 'l. IX, fig. 12 , for comparison with those on the left side of lobatus when the volution was about the same breadth. 'There were five divided saddles on both sides of this fossil.

Locality: New Jersey, Mississippi.

Age: Ripley group, Upper Cretaceous.

Sphenodisces stantoni 11. sp. Hyatt.

PI. V, fig. t: PI. VI, tig 5.

This is founded upon two casts from locality No. 1473 (Coll. U. S. Geological Surver). There is no distinction, so far as could be seen, to separate this firom $s$. lenticuluris except the sutures. These have, however, so much broader and shorter sadrlles than any sperimen of that sprecies I have ever seen, that, if there is any specific listinction in such peculianities, these fums can not be inchrled in lenticuldris. The same peculiarities, as 
well as the fact that the sides are smooth and entirely withont tubereles, also separate it from plemisepta.

The diameter is not far from $114 \mathrm{~mm}$. The partly preserved living chamber of the largest cast is not less than one-half of a volution in lengtl. About midway the diameter from line of involution to venter is $68 \mathrm{~mm}$., that of the same rolution opposite this, partly estimated, is $44 \mathrm{~mm}$., the umbilicus being only $2 \mathrm{~mm}$. The keel was solid in the ephebic stage. The basil suture and the next or second one are applarently incomplete on the right side, but on the left they are both present but depressed toward the umbilical shoulders. The last three sutures are more closely approximated than others, as if the shell were in the gerontic stage.

The sutures lave minute marginal lobes on the saddles and lobes. The first lateral saddles are very short and broad and quadrifid, the marginal saddles are small, but still distinctly subphylliform, as are also the second, third, and fourth; the fifth is distinctly phylliform and bifid, the sixtl just beginning to be hifid on the left side, while on the right side it is still entire. ${ }^{a}$ The remaining saddles form the ustal series, flattening out on the bases near the umbilicus. On atcount of the short saddles the sutures are as widely separated on the renter as in lobutus, but a slight orerlapping begins at the third rentrals and continues to the umbilicus, in so far as the sutures were seen in this direction. The smaller specinen has even broader and stouter saddles, but the umbilicus is nut so muclı contracted. There were five divided saddles on the left side of this specimen and six on the right side, just the reverse of the larger fossil.

Loculity: Eighteen and one-half miles southeast of Eagle Pass, 'Texas Aye: Eagle Pass beds, Upper Cretaceons.

\section{SPHeNodiscus lenticulakts (Owen).}

Pl. VIII, tigs. 1, ㄹ: Pl. 1X, figs. 1-6.

Almumitas lentienturix Owen, 1852. Rept. Geol. Surr. Wisconsin, Iowa, and Minnerotit. 1. . . . 9. pl. s, tig. .5.

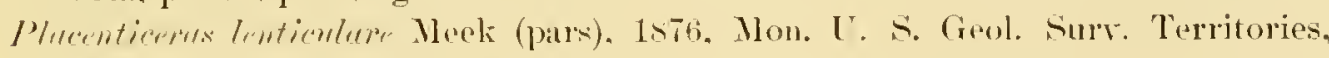

Vol. IX. fig. 66 on P. 473 and pl. 34.

Neek's original specimen, from which his figures were taken, shows that these are accurate with exception of certain minutias. Figure on page

"The sixth column of sarklles was entire on the left side throughout: on the riglut it was just beginning to show a dividing marginal, the diameter of the sile along this line being alont $53 \mathrm{~mm}$. 
473 of the work cited shows acute wings to the siphomal saddle; these are phyllifom in the speromen, as is usual in this spexies. The marginal lobes of the ventral lobe are tom pointed in this figure. The aniliary saddles have not the acente colners as figured. The antire sarlelle in fifth column of lowest suture is a mistake: it is bifid like the uthers above. The siphonal sardle is mot perferty entire: there is a minnte marginal depression on either side of the rentel" which is tongated, forming a very minute-pointed lout narow sadfle on the keed. The umbilicus is juesent and plugged with dak matrix, and the shell is present all around and is rery thick. 'This was entirely orerlonked in the drawing. The figure on pl. 34 was taken from the since suecimen before it had lost the very friable shell that once covered the sicles, or else the shell wis in laree part restored. In this figure the umbilieus is too latrge. T'le fold-like costice as figured are visible only on the onter half of the outer volution, but are slightly rurved, not straight, and alre more deciden than in the tigure "The imner half of this rolution and the outer part are smooth zones with no elevations perceptible to the eve or tomall.

A fine vonng one of this species (Pl. Ylll, figs. 1, 2) (Coll. National Musemu, Morean River, South Dakota), has the living (damber only partly preserved. The septa and sutmes are straght and closely approximated even at this stage, but the overlapping in consequence of this is more decided near the mubilicus, the two nuter saddles and tirst lateral lobes being frew on account of a slight bend orad in this part and the greater space at the periphery. According to Meek's figure the increase in size and lenetl of these sardles in the later stages brings them into contact. The lobes and saddles of this specimen are similar to the style of Meek's woodcut on page 473 , differing only in certain details.

'There are six colmmus of divided saddles on the left, the only side visible; the first and second are just passing from the bifid to the trifid type, the thind and fourth are also passing from the bificl to the quadrifid type, the fifth is hifid, and the sixtl passes on the first and second quarters of this volution from an entire outline into a bifid condition. The five inner columms alle entire and the fiftl column is seen coming in on this rolution. The spiral arrangenent of these inner entive saddles is prettily shown in the mubilicas.

The Ioles all belong to the trifid type except the three imner ones which ale entire. There is a stealy series of gradations in complexity 
begiming with the fourth eolumus of saddles and lobes, both beeoming: simpler toward the umbilicus. This is parallel to the development of any row taken in the ontogeny, as explained in the general dexcription. There are eleven lobes and twelve saddles, besides the arm of the ventral lobe on each side in the oldest part of this volution, and at least one, perhaps two, rows of lobes and one row of saddles less on the very earliest part of this rolution wluen the shell was $26 \mathrm{~mm}$. in diameter, and form renter to line of involution abont 9 mus. The saddles, when a little older than the sutnre figured, had the phrlliform outlines of Meek's tigure and were planily growing to be more like lis tigure on pl. 34 . Fold-like costie about $1 \mathrm{~mm}$. apart ocem, but these are elevated above the general surface only along the median surface of the sides. They are obsolete outwardly; and inwardly they are mere elevated lines. The involution alnost completely covers the rolution even at this stage, and the mombilical opening is only about 21101 . in diameter.

The venter is acute on the youngest part of this rolution, and the shell is thin. the immer coat brilliantly nacreous; the ked is solid. This is probably the young of the same species tigured by Meek on pl. 34 , since some of the first lateral saddles alleady show the tendency to attenuation and the phylliform ontlines of the natrginal saddles common in that form. The siphonal siddle also has the same form as in that species, and the dependent maromal saddles on either sirle lave the peenliar ronnded aspeet of the same parts as figured by him. The arms of the ventral lobe are long and directed laterally, and distinctly trifid. The whole diameter is $42 \mathrm{~mm}$., diameter at last septum is $30.5 \mathrm{~mm}$., broadest rolution from line of involution to venter 19.5 , umbilicus $1.5 \mathrm{~mm}$, and smaller part of same volution opposite $9.5 \mathrm{~mm}$.

Fragments of one or two specinens of the same species (1'l. 1X, figs. 1-6) as the above, from Rock Creek, Wyoming (Coll. Yale Musenm, No. 1697), show similar sutures and dharacters The age and size of this are about the same as of the one described above. There aro seven narow phylliform dorsal saddles in the zone of involution. 'l'he next to the youngest fragnent of a volution was $4.5 \mathrm{~mm}$. from venter to line of involution, with a transverse diameter of 2 mm. Even at this early neanic substage the form of the venter was like that of the adult and the involution almost completely concealed the next imner volution, which was paranepionic and ruite distinct in form. 'The diancter of the youngest 
volution is about 1 mun. from venter to line of involntion. The transverse section is stonter than in second rolution, the outline being halmet-sliaped, and the renter elevated and beginning to be subacute. At this stage there is one large trifid siddle and one large lateral lobe, and the large inner saddle has two maryinal saddles and one on the line of inwolution. This chabled we to see that the first to thind saddles and first to second lateral lobes of succeeding stages were male by division of the first nepionic saddles. The third lobe of the adult consequently represents the primirive lateral nepionic lobe, and the remainder of the saddles and lohes were derived from the division of the outlines of the magnosellarian or seemd lateral nepionic saddles. In the zone of involution there is a deep antisiphonal lobe and a pair of large saddles with a pair of broad lobes and small saddles at the lines of involution The specimen has the color and transparency of anber and the enlarged drawing (Pl. LX, fig. 2) represents what was seen. There was a decidedly wollen joint at each septum of the three seen. A collar was dimly seen, and there appeared to be but one long fumel reaching across the chamber. This seemed to be thre fact, and yet $I$ do not think it was elear enough to be considered certain. Such a long fumel would be a remarkable case of arrested development, especially when a collar was present. It may he that the appearances were due to the entire absence of any true funnel. This last view would entirely reverse the statement and show a high degree of acceleration, since the disappeanance of the fumel usually takes place later in life in most Jurassic and Cretaceons forms. In the neanic substage, perhaps in the anineanic, above mentioned, the first three saddles still show the curvature of the great first lateral nepionic saddle. The ventral lobe is broad, as in the adult. The siphonal saddle is prominent and broad, but as yet shows no digitation, only a few faint indentations. The arms of the lobe are just passing from the entire hastate to the trifid type. The first two lateral lobes are in the same condition, but the saldlle remains entire and alub-xlinped. In fact, at the stage immediately preceding this, the three principal derivative saddles and lobes must have been almost exact repetitions of those of P'rolecanites among Goniatitince. The fourth saddles are entire, but rather short, and beyond are three saddles still very primitive in outline. The hursal has an entire antisiphonal, more (nub-shaped than in the younger stage, and there are four oblur pairs of 
zyogous entire saddles and three pairs of similar lobes. The globular first stage had heen lost ont of this fragnent before it came into my hamds. The sutures have five colunus of bifid saddles on the right side and six m the left side when the volution is abont $10 \mathrm{~mm}$. broad. 'T'he suture figured was taken from a volution about $12 \mathrm{~mm}$. broad transversely (Pl. IX, fig 5). The dorsal sutures are of the sime age, but were drawn on a larger scale by mistake and have been separated as a distinct figure on that account.

There is an interesting small specimen in the Academy of Natural Sciences, Philarlelplia, said to be from near Santa Fe, N. Mex. In this musenm and in the United States National IInsenm there are fragments of volutions of large size having very hroad, coarse, low folds on the onter half of the sides: these may belong to this species. The largest is $102 \mathrm{~mm}$. from line of involution, which was not wholly complete. The sides are rather gibbous, the venter still subacute, although not so sharp as in carlier stages. Through the thickest part about $34 \mathrm{~mm}$. from keel the transverse diameter is $51 \mathrm{~mm}$ The absence of tubercles at all ages was completely demonstrated in this species. The concave zone found along the imner half of the older rolutions in S. pleurisepta and lobatus was not present in this species, although low, fold-like, arcuate costix were found as figured by Neek in older stages on the outer parts of the whorls.

Lorality: Moreau River, Soutlı lakota; Rock Creek, Wyoming; Santa Fe, N. Mex.

Age: Fox Hills group, Upper Cretaceous.

Sphenodisces lentoctlaris valiety splendens Hyatt.

Pl. VIII, figs. :3-7.

A young fragment broken out of an older volution is in the form of a cast, but with the sutures and septal partings beautifully marked. It has the usual ax-like venter of its congeneric forms, with fold-like, arcuate, very obscure costie showing on the outer parts of the sicles. The extreme acuteness of the venter shows that this species had a solid keel. The first to the sixth saddles an the right side and the first to the fifth on the left side in the smaller cant and also in the larger are bifid. An observer seeing the young on one side and the older frament on the ofleer would be apt tor consider this lateral clifferences as a distinetion due to age. 'l'he 
basal pirts of the sarllles have marginal lobes like those of lolutus, but these are longer and divide $u$, the body of the saddle more completely, making a mone conplicated outline, with long, phylliform, marginal sablles on the first three surldles. The lobes and sarldles of the inner part are rely closely similar to the older anes of the typical specimens described above, having sinilan firlliform hranches and deeply cut ontlines.

At a diameter fom line of involution to venter of $43 \mathrm{~mm}$. in the younger fraguent the sutures are clusely approximate, the outlines orerlap slighty on the third, fonth, and fifth colnmms and then sepanate toward the centran surface, but remain ciose and hecome overlapperl again near the undilicus. The lohes and saddles are comparatively long and with highly complex outlines even at this stage, and the phylliform maginal saddles remind one strongly of l'hylloceres. These are shortes and stouter than the sinne parts in the older stage, but even at this stage the first lateral saddles are more complex than the sutures of var. mannificus and the whole aspeet is more phrlliform. The first lateral saddles are trifid, but obvionsly modified from the bifid type; the second, third, and fourth are quarlifid, modifien from the bifirl trpe; the fifth is bifid; the sixth is begimning to show the bifid division on the right side, but on the lett is entire. There are twetre saldles in all, but the remainder are entire and tend as usual to become shorter and flatter. The rentral saddle is similar to that of ras. mugnificus and S. Inbatus, with large, rounded, marginal saddles at the corners. The rentral lobe is broad with broad and short branches, belonging to the trifid trpe. The remaining lobes are complicated with marginal hanches, but are of the bifid type, although this is not so noticeable in the first five lobes as in the smaller and less complex ones of the sixth to the twelth column. There nay have been me more pair of lobes inside of these which were broken away.

From line of involution to venter the lasge fragment had a diameter of 103 mm. with the same surface features as on the smallel cust, but with the venter not so acute. The sutures are older and more complex, as noted above, and there were the same differences ben ween the two sides.

There ane twelve lobes and thirteen saldles, and the was certainly one row of lolses brokes away and probably another of sardles gone from the mubiliral erloge. The inmer three sadilles are considerably flattened: the next four lows are rotuml, as in the younger stage describerl above: and 
the other rows to the venter have the elongated aspect of the ephebic sutures of this variety. The outer or first laterals are slightly more distant froni the lobes than in the ephebic substage, but the second, thind, fourth, fifth, and sixth laterals overlap the lobes more than in that stage. The contour of the renter and aspect of the sutures do not indicate adranced age. The largest fingment was probably only in the parephebic or anagerontic substage and nunst have belonged to a much larger shell.

Mr. Stanton has kindly sent me a tracing of a suture from a large specimen which he supposes is the one that furmished the suture figmred by Metek on pl 34. 'This sutme has attenuated saddles and lobes more like those of var. splendens than the trpieal lenticuluris.

Loculity: South Tikota.

Age: Fox Hills group, Upper Cretaceous.

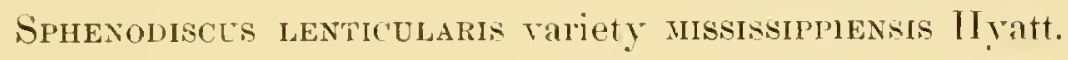

PI. IX, figs. 7-9.

There are two more or less crushed specimens in the National Musemm from friable marls on Owl Creek, 3 miles northeast of Ripler, Miss., No 20863. These have smooth shells, except for well-rlefined hands of growth, and evonly convex sides and sutures that are more like those of lenticularis than those of any other speries. The lohes and saddles are remarkably long and similar, and althomgh the ventral saldles are different, they are not widely different. 'The largest fragnent, belonging to a fossil probably abont goo mun. in diameter, has only tive colmmns of divided saddles on the right side (Pl. IX, figs. 7, 8). The anetual breadth of the side where this suture was sturliud is $111 \mathrm{~mm}$. The dorsal saddles are remarkably unstumetrical, and these and the antisiphomal hobes are different trom those of the westem rariety splemens, and further investigations may show these to be distinet, but the materials do not seen at present 10 justify a sepanation. 'The suture of the smaller specimen (Pl. IX, fig. 9), taken where the side was about $7.8 \mathrm{~mm}$. broal, agrees, cunsilering the difference of age, nearly enough with that of the precerling to be placed in the same valuety, but the dorsals were not seen. This cast is identical with that shell in extemal aspert aud has the shell partly preserved on one side. This has the usual brillianty nacreous layers, and what seems to be 
the external layer is also nacreous. The gownth ridges certainly give the aspect of an external shell, hut the may be due to the fact that the seromel or midile layer takes the lines as inpressions firom the outer layer, which is absent in this and in the langer fossil also. This last las a very distinct nomacreous or only faintly nacreous inner layer; the middle laver is brilliantly nacreous, as usual, but the lines of growth, although present, are not so well marked as in the smaller sperinen. In both specimens these lines indicate a well-marked rostrun with broal latem] sinuses, median lateral, broad crests-similar brom simnes internally rising toward the umbilical shomlers. The diameter was partly estimated at $157 \mathrm{~mm}$; the diameter of living chamber, which is nearly complete and one-half of a rolution in length, is about $90 \mathrm{~mm}$. at aperture.

A cast fiom South Carolina (Coll. American Musemu of Natural History, New York), is $151 \mathrm{~mm}$. in diameter. 'The living chamber is a trifle over one-Jalf of a volution in length where complete on the rumbilical shonlder. The form and other chatacters are like those of lentirularis and the saddles have exactly the attennated ontlines given in Meek's pl. 3t, but are much shorter, and are also quite distinct from those of Meek's otlier figures of this species. 'The anxiliary sadilles have the peculiar plytliform bases given in that figme. The inner edge of apelture is present on one side and shows that internally the living chamber was about one-lialf of a volution in length. The renter was solid. Steinnam, in his Elemente der Palaeontologie, Vol. II, p. 415, figures a specimen said to be from upper Missonri, with the trpical suture line of this species, but having a line of median lateral nodes. He gives four derivative lateral saddles, but there are, in my opinion, onty three, the remainder belonging to the anxiliary system. The nodes may be the inner temini of the costre, perlaps slightly more prominent than usual. True nodes are not present in any specimen I have seen.

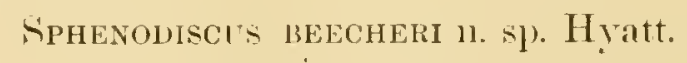

Pl. VI, figs. :3, 4 ; PI. IX, tig. 10.

The type of this species is a large specimen in Collection of the Musemm of Comparative Zoologry, labeled "Central City, Colorado," but the real

"Ir. Stanton has most kindly mrected this as follows: "This locality is an error. Central City is in the midst of a granitic region and $: 30$ or 40 miles from the nearest Cretacenus outerops." 
locality is probably Fox Hills, Dakota. It is $263 \mathrm{~mm}$. in dianeter without the shell, which was not present on the renter. The shell wosuld have increased the measurement to about 267.5 mun., judging by the shell preserved on the renter of the next inner volution.

The living chamber is complete and about one-half of a volution in length, and the diameter, from line of involution to venter, is $150 \mathrm{~mm}$. The outlines of the aperture are sufficiently well preserved to show that it las in this old stage very low, broad erests on the sides, slight simuses between these and the rostrum; this hast being also obtuse and not much extended, the outlines being the same as the lines of growth describer elsewhere. Even at this large size the renter is still acnte. 'The immer volution is covered and the mulbiliens is only about $1.5 \mathrm{~mm}$. It is as near as possible to being completely eloserl by the thick shell, although in casts it is obviously much wider open. The shell is about $3 \mathrm{~mm}$. in thickness near the lines of involution. It is also quite thick over the entire last volution, whenerel present, and consists of the usual onter oprane, middle iridescent, and innel pearly layers. The keel was solid, sn far as seen, at all stages.

There are fold-like olscure costa, rery hoad on the oldest part and visible only un the onter part of the volution, an in the casts of S. lenticularis var. splendens. 'The venter has the same form as in the young, namely, an ax-like solis edge with bieonvex sides to tlue edge, forming obsenre smooth zones on either side. There are no tuhereles on any parts visible, but the bands of growth, as in wher speries, are very well marked on the outer shell. The sutures (1'l. IX, fig. 10) have !noader sadtles than thrse of Meek's figure on pl. 34, lunt they are quite similar to tluse of s. lenticularis variety splembens, except that they are nore complex and have a larger number of divided saddles.

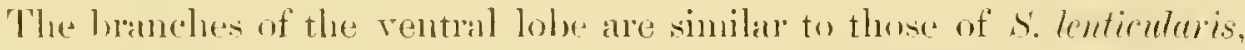
but longer and narrower. The first lateral is murle shorter than the rentral branch and the secomel lateral lobe, and the secomd lateral is shorter than the thirri lateral, so that this part of the suture is deeidedly convex and las not the flat anect of the sane part in Meek's figure. 'The lobes are alser of the trifid trye, a difference not accomnted for by the difference of ace, as is the fact also that they are more emmplicated in outline. The fourth to the eighth are quadrifid, as are the seromd, third, and fourth in 
Meek's figure and alse sixth, seventh, eighth, and ninth, while the founth and fiftl are trifid. The ninth lobe is of the primitise tritid trpe: those interion to this were not seen. The first lateral soldele is mormmetrically. trifid, the second to the fonth more srmmetrical but rather irregularly: quadrifid, the fifth ame sixth trifid, the seventh, eighth, and ninth bifid, with broad phyllifim bases, the tenth entire. 'The remainder, probably. at least two more, were not seen.

The lines of the sutures are quite distinct and are separated by a comsiderable interval to the third lateral saldle in the older septa, and in the rounger septa this separation is maintained until the immermost lines of bifureated saddles are reareled.

A fragment firm Fox Ilils, collection Musem Comparative Zoology, No.397, shows that this species must have attained a much larger size than the specinen described above. The sutures are visible on this fossil, the partly estinated brealth of the sides being $180 \mathrm{~mm}$, the transwerse diameter through the zone of involution at the fifth pair of dorial and eighth pair of lateral saddles being 65 mm. There are severn pairs of divided sardles. The first laterals are yuarlrifirl on right side and bifir on the left side, the second to the fompth are puadritid on buth sides, and the fifth to the seventl, bifid on both sides. The uext or eighth pair are entire. The volution was absent beyoml this line. The outlines are olwiously sinilar to those of $S$. lenticularis var. splendens, and the dorsal including the antisiphonal lobe also resemble that varety and are nore cross-shaped than in Pl. IX, fig. s, which gives the dorsals of $s$. lenticularis rariety mississimpiensis. There are three lavers present in the shell.

A fragment of a cast (Pl. YI, fig's. 3, 4), collection Yale Museum, No. 200, from Birmingham, N. J., from the Lower or Middle Greensand Ilats, Lpper Cretaceous, evidently in its ephehic stage, shows sutures that are quite different from those of any other form. The renter is destroyed except in one spot, but this is sufticient to show it to be solid and acute. The volution is stouter than in typical lobutus or lenticuluris. 'The atenal diameter from line of involution to renter is 61 mm., and it was probably a few millimeters deeper: the transterse dianeter liese is 25 nm., this being also a fer millineters shorter than the actual diameter.

The ventral lobe is broarl, and it is also evident that the siphomal sald-

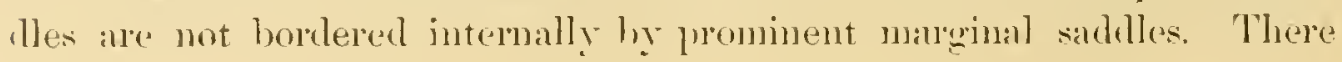


are twelve saddles on the side and there may have heen one more. The first four lateral sadtles are similar to those of lentiruluris, but are succeded internally by nore pairs of divided saddles, and the dorsil tobes and saddles differ. The first to the third are quadrifid; the fourth is of same type, hut las three marginals on the onter arm; the fifth to the seventh are simply bifid; the eightl is entire; the ninth is bifid; the tenth and eleventh are entire and phylliform. The lobes are all symmetrically bifid, the branches subdivided and serrated, but the bases between saddles are entire on both sides; even the eleventl lobe is bifid and has minute serrations, and all the smaller internal hobes are short and broad. There are ten narow phylliform dorsal saddles with entire bases in the zone of involution, and probably there were originally eleven. The lobes are broad, bifid, and digitated like the opposite external ones; the saddles alone are quite different. The first dorsals are very narrow, almost linear, and the dorsal lobes are bifid, narrow, and long, orerlapping as in other species of this genus. I lresitate to describe this as a distinct speeies, because it is a fragment, but its sutures ean not be reconciled with those of any other species.

The side, as slown in Pl. VI, fig. 4, is evenly convex as in S. stantoni.

A specimen from the friable marls 3 miles northeast of Ripley, Miss., accompanied a specimen described above as $S$. lenticularis var. mississippiensis. It was from 75 to $80 \mathrm{~mm}$. in diameter probably when complete. It is covered with nacrs, but the sutures can be seen sufficiently. At a stage when the side is $35 \mathrm{~mm}$. in breadth the sutures have the complex aspect of this species in the first four saddles and lobes, the tifth to the serenth are bifid on both siles, and there are ahout eight more entire saddles. This specimen appears at first to be identical with the var. mississippiensis fiom the same locality, but while the external aspect is the same the suture line, even at this comparatively early age, is like that of beecheri

A very time aast from Momnt Wahallak, Kemper Comnty, Miss., collected by Frederiek Braun, of Brooklyn, in arenaceous rock in lower part of the lotten limestone, slows the sutures predectly and also the inner part of the living chanber. The latter" is one-half of a rolution in length.

The suture shows eight livided saddles on each side and the form and aspeet are like those of this species. 'This fossil has folds on the outer half of the outer volution, the inner part being smooth and the sides evenly convex. Whole dianeter, partly estimated, is $145 \mathrm{~mm}$; the diameter MON XLIV- $08-6$ 
at hase of living clamber is $120 \mathrm{~mm}$; breadth of side at this line $67 \mathrm{~mm}$, to thr shoulder: umbilicus (no slell present) 8 mm. Greatest transverse diameter, $23 \mathrm{~mm}$, is along the median line in the same plane; no sledl j)esent.

Locality: Fox Hills, South l)akota.

Age: Fox Hills grouly.

\section{SPIIExODIscius koxinckl 11. sp. Hyatt.}

Pl. Nll, fig. s.

This is a cast in fragnentary condition with one side abraded, but the l'ight sirle in excellent condition. The whole diameter was abont 150 mm. The side is smonth near the mubilical shoulder and has the usual obsolesrent folds on the onter part of the lateral zone. The suture figured shows the rery large siphonal saddle. While the other saddles and lobes are sinilar to those of 5 . lentimlaris, they are not irlentical. There are six divided saddles on the right side. Those of the left side were obliterated.

Loculity: Near Maestricht.

Age: Senonian.

\section{Sphexoniscus Binckhorsti Bülmm.}

Ammonites pedermalis Binckhorst, 1873. Mon. Gast. et Céph. du Limbourg, pl. 5a', fig. 2 and id, fig. 1 (no others). sphenorliscus binchihorsti Böhm, 18!4. Zeitschr. Deutsch. greol Gesell., Vol. L, p. 1:17.

This species from Limbonlg as figured by Binckliorst is a close ally of our American S. pleurisepta, but has only one line of nodes, witl costa arising from these and radiating outwardly; apparently there is no outer line of nordes. It is said to have been compared with lioemer's originals. 'This learls we to think that these must include more than one species.

\section{SPHenoniscus ubagshi Grossomre.}

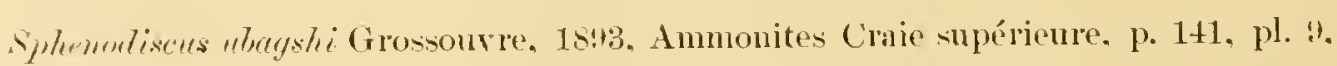
tig. $4-6$.

This French speries is more like onr S. Iobutus than any other species, but the principal lateral saddles have less lobate ply lliform ontlines. The sutures lave the small first lateral saddles common in this genus and five divirled saddles.

Age: Tpper Campanian (uppermost ('reticeous). 


\section{Spienodiscus Rutoti Grossouve.}

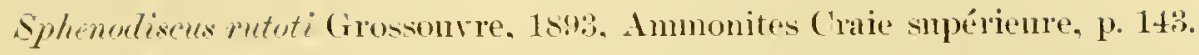

This French species is obvionsly elosely allied to st. ubayshi, but the three principal laterals are very distinct from thiat and from any of om species.

Age: Upper Campanian (mplermost C'retaceous.)

\section{Sphenodiscue siva (Forbes).}

Ammonites siec Forbes, 1st5. Trans. Geol. Soc. London, 2d series, Vol. VII, 1. 111, pl. 7 , fig. 6.

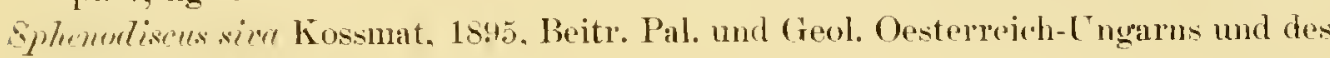

Orients. Vol. IX, pl. 22, fig. 2.

This species, as fignred by Forbes, is completely involute, smooth, and probably has an entire keel. It is extremely acute on the venter and highly compressed. There are thee complex, narmw, deeply cut derivative sardles, with phylliform marginals. The venter has a prominent pointed siphonal satdle according to the figure.

Agp: Valudayur beds, [pper Senonian.

\section{EULOPHOCERATIDAE Hyatt.}

This group appears to be necessary in order to separate the remarkable series of forms included under this title from the Coilopoceratida. 'The forms include Tegoceras, which was, according to d'Orbigny's figure, a form with a remarkably romuled volution in the gerontic stage, but having a venter like that of styracoceres in the ephebic stage, and a second genus, which is exactly similar to Coilopoceras in form, compressed, and with an acute venter. All of these have peculiarly solid, low, broad saddles and short lobes, the marginals being simple and not usmally branching, but often long, narow, and tongue shaped. The first two saddles may be reckoned either as me very broad saddle or as two, the divirling lobe being small. The anxiliaries are also very peculiar, and in Coilopoceras the imermost is a long sweeping curve. Su fiu as the evidence goes, Eulouhoceras apjears to inve had a different origin fon Sphenodiscus and Coilopoceras, as, indeer, is quite elearly indicated by the sutures. Tegoceres probably had a solid keel, but no direct observations liave been made upon this part of its shell. 
The derchoment of Eulophoceres indicates quite clearly derivation from the sanne commonstock as Burkeres and the Tissotida, and it should be noted that the sutures are more like those of Buchirevas, in having very laroge, broad first and sceond lateral saddles. The form indicaterl for the epllebie stage of Tegoreres in d'Orbigny's tigme sugegests that here, as in the Tissotidse and Coilopocenatidax, the more prinitive species lad truncated rentris with keels and lateral tubercles.

TEGOCERAS" n. gen. Hyatt.

The curious form figured by d'Orbigny as Ammonites mosensis is obriously entirely distinct from any species heretotore described, so far as 1 know. The external ontline in the gerontic stage in section is oval, with romeded renter and only slight involution. There were obviously large alternating noles on the renter of the inne ephebic volution and a somewhat elevated and bluntly subangular venter. These characters are combined with sutures having in the werontic stage a large first lateral saddle divided as in gevriliame, so that it is probably really two principal laterals. 'The anxiliaries are irregular and pseudoceratitic in outline. The peculiar crowded, tongue-like, elongated, marginal saddles and lobes are similar to thuse of Eulophoceras, and it is mentioned in this paper on that account The only species known is the following:

T'EgOCERAS MOSENSE (J'ORHGNY).

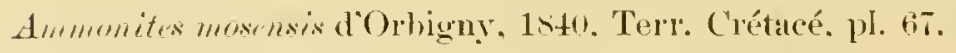

Age: Albian.

\section{LENTICLRAS Gerhard. ${ }^{b}$}

This wenus, described by Gerhardt in his Kreideformation in Tenezuela and ${ }^{c}$ P'ern, had for its type Lenticeres (Aum.) andii (Gabb). Being unable to compre this with Gabb's types that have apparently disappeared, it is

"T'́y оธ, ruot.

b In Zittel's Text-book of Palaentology, Vol. I, J. 590, Professor Hyatt reters this genus, together

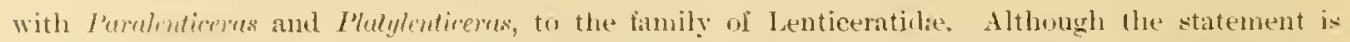
not directly nuale that the family is abandoned. it may be inferred from the reference of Ilntylentirems:

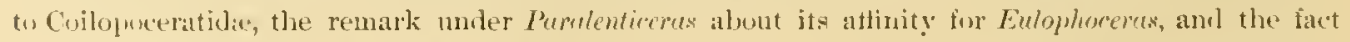

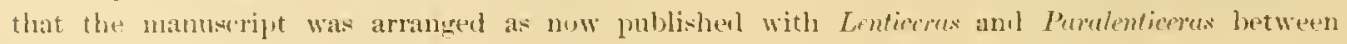
Teywros and Eveluphlecerus.-T. W. S.

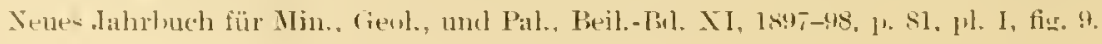


not practicable to say that these precies are illentical, as supposed by Gerhardt. The drawings certainly differ materially. The sutures are more like those of I'orrenticerus than those of any other groms that I know. The siphonal siddle is very large, the first lateral saddle las three lome arms, the onter one the shortest and the inme one the longest. The first lateral lobe is narow and tritid with long bifid arms. The outer lobes are narrow also, whereas the saldles are rery broad and solid and have short romuled marginals.

The volutions are depresserl, helmet shaped in section, and very broad, without keels, but have smooth shells with lroad fold-like knobs on the umbilical shoulders.

\section{PARALENTICERAS Hyat.}

This is a highly compressed involute smonth shell with sutures mulike those of any other known genns axcept Lenticeras. Aluhongh so compressed and smonth that it resembles I'latylenticeras, it is obvionsly a member of the same genetic series as Lentireras. The excessively olongated and chuhshaped matrinals also indieate aftinity for Enlophoceres.

The gemus was mentioned in Zittul's T'ext-book, C'ephalopoda, page 590, and placed in its pune relationship to Lentireras.

The sutures have the same lumel first lateral saddle with thee arme, the shortest next the rentere, as in Lenticeres, and similar seeond and third laterals. All the outlines ane also of the general ontline acompling to Crerhurelt's figures.

I fail to recognize any special resemblances to the sutures of Ammonites rlypeiformis dorlo., which las a type of sutme found in chiloporeras and its allies.

Only one speries is known to ne, I'. (Amulthens) sirversi Gerhamb.

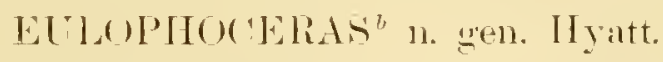

This genus is proposed for slells similar to Plutglenticeres, but the sutures ohviously lave only two principal laterals, derived from the primitive furst lateral saddle, and only a fer broml anxiliary saddles, the inner most being axtremely broal.

Only one species is positively known at present to be in this gemus.

"Neues Jahrbuch für Min., Geol., und Pal, Beil.-13d. XI, 1847-98, p. 79, pl. 1, fig. 5.

hev̉dopos, haniwome crest. 


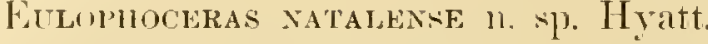

Pl. XI. figs. ㄴ-ti.

This species is fomded upon a fiagnent in the collection of the Yale Museum. It is a bare east on one sille with the shell preserved on the mposite, right side, and on renter: Diameter, partly estimated, is 164 nm. (actual dianneter $155 \mathrm{mmn}$.). There is 110 umbilieus, this heing practically sealed up by the growth of shell on one side, and is of course very small, where rleaned ont on the other" side. 'T'here are faint folds on botl shell and cast. The folds ocenpy the sides and are not confined to the muter wr inner parts of the lateral surfaces, although more prominent along the erutian lateral lines.

The keel is solid in the rounger stages (Pl. XI, figs. 5, 6) and then beeomes apparently hollow. The proof of this is not absolutely clear, but in each volution of the section there is a pratition of shell ontside of the siphuncle. In the mper tip of the section of the volution next to the last a partition was also present, but this is apparently a section of the septum itself, and what seemed to be the siphuncle is represented on the right and above this partition. If this be correct the keel is solid at this age and remains in this condition in the last volution. The siphmele is not present in this last volution, but as in the section of the next yomrger volution above described the common matrix fills the interior completely and on the outer exposed edge the sutures run against the solid interior of the thick deposits of the keel. In the younger whorls the space between the partition above the siphuncle and the keel is filled, as in the interion of the siphuncle, by dark transparent calespar. There is, lowerer, no black layer present above the siphuncle, as in the Jurassic foms, that have hollow keels

The sutures are extrandinary" "They are so exressirely overlapped that there are two seeond lateral lobes telescoped into every third one, so that one has to disentangle the lines of three consecutive sutmes in marking ont this lobe. It becomes necessary, in fact, to infer outlines that can not he seen, the sutures latring in some parts necessarily passed along the same liness and can not be separated by the eye. The first to third lateral sidiltes are brad and have munelons long longue-shaped marginal saddles. 'The fourth lateral sardle is also broad, leeply bifid, the onter arm entire, the inner bifid. Dhont half of a volution earliel this saddle is much marrower, and is porobably still smaller at yomgel stages. The tifth is also a 
broad saddle, but shorter than the fourth and has two arms, the outer bifid, the inner rrifid. 'The sixth is a long entire remuant of the prinitive second lateral siddles of the nepionic stage orcupying the umbilicus. The immer part of the outline of this saddle is faintly concave, especially where it crosses the shoulder, but no definite lobe is formed. The lateral lobes are cut up by marginals on their entire ontlines. The first laterals are about as long as the short narrow arms of the ventral; the second lanterals are about a third longer and fully twice as broad; the third laterals are about the same size and length as the first laterals: the fourth are shorter and about the sane breattlı; the fifth is narow and divided by two minute tougue-like saddles. These form a column neur the umbilical shoulder of the cast.

On the right side the third lateral or first anxiliary saddle is very much smaller at the same age, and apparently sublivided with at least me dividing lobe, giving one nore lobe and one more saldle on this side. The fiftl is also narower and las a simple trifid outline. The remaning sadtles and lobes also diffur, and in fact this side of this specimen might be described as belonging to a distinct species. 'The first and second laterals are larger and the marginals fewer in unmber, but the principal difference lies in the second or primitive lateral lobe. 'This is bificl, divided by one very large median marginal saddle. 'There are, howerer, but two principal lateral saddles om lontl sides.

The outlines of these sutures are entirely distinct from those of any species of Sphenodiscus. "The bodies of the saddles are solid and the complicater ontlines are made by the ontgrowtl of long tongue-like marginals, the lobes being divided in the same way. The only suture so far figured having a similar outline is that of Teyocpra. moscnse.

The ventral lobe is very broad, the outline sinuous, the center occupied ly a small lobe divided by a slarp minute saddle. There are two arms to the ventral lobe, short, narrow, and bifid, and parallel with the venter. Those are quite different from the nsual spreading arms of this lobe in Sphenodiscus and Coilopoceras. The auxiliary saddles are even more distinct as describer above and together witl the number of the principal lateral sarklles show that we are dealing with a species that can not be includer in Sphmoriscus nor in Coilopoceras.

Locality: Port Natal, Soutl Africa.

Age: Upper Cretareous. 


\section{COILOPOCERATIDA Hyatt.}

This includes genera having the prinitive first lateral wirldles far more

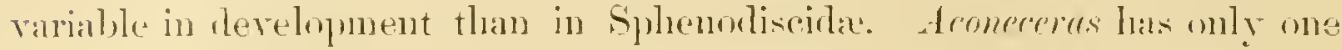
long deeply divided first lateral. Platylenticeras and Coiloporras lave three aceording to the method of rerkoning adopterl helow, but the elements are the same as in Aconerents. Aroneceras, Styracocerts, and I'latylemtireves probably lave solid keels, although there are mo whervations on this point that can be guoted.

The development and alult form of Styrapoceras indieate that the more primitive forms of this fimily harl truncated venters with krels and lateral tubercles, and were similar in extermal aspect to Buchiceras.

Coilopocertes has a hollow keel. The sutures and development at first seem to place it in the same group with Sphenodiscus, but the two principal lateral saddles, the median lateral lube (second lateral lobe) with long tongue-shaped marginal saddles, and the aspect of the anxiliaries in the young indicate association in the same family with Aronecrus.

These remarks show that while these gencral are suffieiently distinct, their association in a group together is made more to call attention to certain suggestive similarities than with any idea that they really belong together exactly as deseribed helow.

The evidence that this funily was directly derived from Plyglloceras or sone sinilar form rests un whe general ontlines of the saddles, which are phyllifmm, espectally in the neighborlenor of the nubiliei, and the wirlely spreading and peculiar lober. The dorsal sutures are an usual less changed than the extemal inflections and these have almost exrlusively phylliform ontlines like those of lhylloceratida. The antisiphomal has a long narrow form with a bitid end and although it is serrated or slightly branching and not so simple as in Plyglloceres, it has a similar form.

As mentioned in the generic description of Aconceres the sutures of A. nisum make a nearer appromeh to those of I'tulloceres than any other genera of this gronp or any other's extept the Sphenomliscidle."

\section{PLATYLENTICLRAS HYatt.}

This genus was mentioned in Zittel's Text-book, page 590, ly the anthor and the tyje given was the sime species cited helow. The sutures are

"The manuscript of this last paragraph bears an interrogatiun mark on the margin, -T. W.. 
similar to those of Coiloporezes but are still more like those styraroceras balduri. The siphomal saddles are small and bitid in these two genera. The small first lateral lobes may be reckoned cither as mere maryinals in this genus dividing the first lateral siddles equally or as true first laterals. The two small saddles coming next to these resemble the correspomeling" saddles in coilopoceras. Uhlig in his l lie ('ephalopodenfama der 'Tesehener. und Comblischter Schichten ${ }^{\alpha}$ figmes several speceses mentioned below, one of which has a rounded venter with the usual smooth sirles and characteristic sutures of this genus. Thlig takes the same position that has been here independently assmed, namely, that the sutures are sinilar to those of Styn: balduri (Keyserlings), and that the affinity of this genus for Mojsisoricsin is shown by the development of one of his speries which has a rounded renter until a late stage. 'The sutures and the attinities of this fossil for' $P$. heteroplenom show that this is a polonged, immature, or arested condition of ontogenic development, and therefore an indication of remote ratler than proximate derivation from Wojsisovirsia, whose sutures are widely d:tferent. The seetion of $I$ '. heteroplemm given by Struckmam shows that the transition from a rombled to an acute venta probably takes place directy at a comparatively early stage, as might be imagned after study ing the ontogeny of $I$ '. psentograsiamum. This fact show's that the resemblanees of the sutures with those of styracorevers have no genetic significance heatuse the extrandinary and complex ontogeny of that genus indicates rery distinet athinities.

\section{l'LatYlentteeras neteropleurum (Nemmayl and Uhlig).}

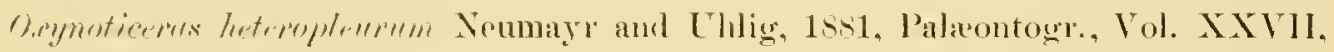
pl. 15. figs. 1, ‥

This species has smonth compressed rolutions but the involution is not sufficient to cover the sides and the mmbilici are quite large. The keel is ncoute and so far as enu he seen in the figures is apparently solid. The sutures as dram by the authors cited are not at all like those of true Orynoticeras, which have only one first lateral sadelle, but are similar to those of Stymacoreas balduri, as stated above. It is not practicable to detemine

"Denksch. K. Akad. Wiss, Wien, Vol. LXXIl, 1901.

"Jahrl, K. Ireuss greol. Landesanstalt, 1889, 1'. 71, pl. 11. 
whetler Ammonites heteroplem.s Struckmann and Amm. yevrilianus Dunker, ${ }^{b}$ which were found partly in the same localities in north Germany, are identical or not, but they are probably the same.

Locality: Near Springe, Hanorer.

Age: Neocomian.

\section{Platylexticeras pseldograsianum (Chlig').}

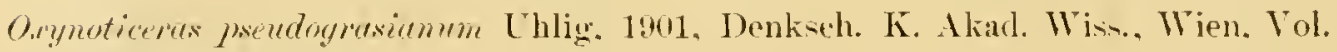
LXXII, p. 25, pl. ‥

This is a really discoidal shell with a much larger umbilicus than other species of this genus, and therefore making a nearer approach to the radical form of Mojsisovicsiu, hut it has on the other hand the characteristic sutures of the $I$. heteroplemrm type; that it should have a romder venter mitil a late stage is quite consistent witl its noninvolute discoidal aspect.

Loculity: Nieder-Iischna.

Age: Talangian (Lower Neocomian).

\section{Platrlenticeras gevrilianum (d'Orbigny).}

Ammonites germiliams d'Orbigny, 1840. Terr. Crétacé. pl. 43.

This species was noted hy Nemmayr and Chlig, in their Ammonitiden aus den Itilsbildungen, as having similar sutures and similar external characters to Platylenticeras heteroplenum, which is, however, in my opinion quite distinct. Aconeceras nisum was also citerl by them as an ally, but this has only one principal first lateral and the resemblances exist only in the external characters. Amm. mureousums, also cited by them as an ally, has only une large bifid first lateral and has a depressed romoled rolution and tubercles like Puchydiscus.

Alge: Aptian.

"Jahr, K. preuss. geol. Landesanstalt, 1ss9, 1. 71, pl. 11, tigs. 3, 4.

¿ Palpontogr., Vol. I, 1851, p. 324, ]1. 4I, figs. 21-24.

cThe other species mentioned and tiqures] by Thlig are not named. They are closer to the

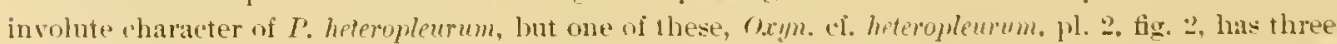
principal sadeles insteal of two and is considerably less involute than that species. 


\section{COILOPOCERAS ${ }^{a}$ 11. ǧen. Hyatt.}

This genus includss species formerly associated with Sphenodiscus, which, however, differ so that they are easily separated. 'The derelopment and form are closely similar; that is to say, the shell develops directly from the rom ded nepionic rolutions into a helnet-shaped whorl in section having subacute venter which hecomes more acute with age. In the three forms described below in the neanic and arlult stages, the rolutions are somerhat less compressed than in species of sphenorliscus, but this is probably only a specific character.

The sutures differ in having broad first lateral saddles with a peculiar large internal arm or marginal saddle, and the first and second laterals, when the second are present, are narrow and rery distinct from the first laterals on.the outer side and the first large anxiliary saddles on the inner side. There are but two secondary lateral saddles, the first and second, derived from the division of the primitive first laterals in C.colleti, the type of the genus, but this form is in an early ephebic substage and the aspect of $C$. novimexicamm at a sonewhat nlder stage shows that there is an approximation to the trisellate condition. This trisellate or placenticeran aspeet of the principal or first outer saddles, derived from the division of the primitive furst lateral saddles, is still more markerl in C. smimgeri. The hollow keel is remarkably distinct. When the shell is remored, the siphuncle is covered only with a very thin layer of the fossilizing sediment, and this organ is apt to be exposed on the casts and is often absent in more or less worn specimens, leaving the venter deeply chameled. This last accirlent is of rare oecurrence among form. with solid keels. The siplnuncle is also larger and thicker walled than in sphenodiscus.

\section{Collopoceras colleti 11. sp. Hyatt.}

Pl. X, tigs. 5-21: Pl. XI, fig. 1.

This species is easily distinguished by comparison with its nearest affine, Coiloprorerns novimexicanum. It has stouter volutions, a more open umbilicus, the venter is bhunter, and in the young, at any rate, it has larger, stonter fold-like coste, one long one reaching to the mmilical shoulder, 
and an alternating shorter une. 'This last series disappear's in the last part of the onter rolution of the specimen described, leaving a series of single costre. These may perhaps he obsolete or obsolescent in older specimens. There is a decided anpect of bifurcation in the earliest stage onserver when from line of involution to venter the east of the volution is 15 to 2011111 , but there are no tubercles. The whole dianterer of this ast is $67 \mathrm{~mm}$. The outer rolution at largest end from line of involution to venter is $37 \mathrm{~mm}$.; without the shell the umbilieus is $7 \mathrm{~mm}$. on one side and 8 mm. on the other side: with the shell it wonld be $5 \mathrm{~mm}$, on one side and $6 \mathrm{~mm}$. on the wher. The greatest transwerse cliameter is about one-third of lateral zone distant from umbiliens and is for thickest part $18 \mathrm{~mm}$, and opposite, corresponding to rentro-dorsal diameter above given, it is $11 \mathrm{~mm}$., both measurements being between the costa. The costa are more prominent on the middle and imner parts of the sides than on the onter, and broaden out toward the renter, disappearing near the solid edge somewhat abruptly on the rounger parts and more gradually along the older part of this volution.

The first lateral saddles are broad and short trifid on the right side, with a small onter marginal saddle and quadrifid on the side figured ( $\mathrm{Pl}$. $\mathrm{X}$, fig: 7), with an inner accessory large marginal saddle dependent on the first laterals. The second laterals are single, short, but sleutler saddles, witl phylliform bases, which are only slightly indented at the age observed. The third laterals are ouly about a third longer than these, and, although overlapping, are easily separated. The ontlines are irregular and deeply indented by two marginal lobes and other accessory lobes. The fourth and fifth laterals are phylliform, with the hases inciented by a number of marginal lobes, apparently entire and small. The sixth and seventh laterals are faintly trifid. The almost entire aspect of these suddles is due to slight abrasion. On the romngest part of this volution (Pl. X, fig. 9) all of the saldles are entire except first to third, the cast licre being $16.5 \mathrm{~mm}$. in breadth from line of involution to venter; the outlines are perfect.

The rentral saddles are more like those of Sphenoctiscus than in norimexicamu, and have rounded marginal saddles at the imer angles. The first lateral lobes are of about the same length as the arms of the ventral lobe, both of them trifid and with accessory marginal lobes orad of these. The serond laterals are the dleepest lobes, and represent the primitive 
lateral. They are hifid and about twice as long as the thind, the arms and sides being cut up by narginals. The remaining lobes are narow as compared with the saddles, and irregularly denticulated. I could not tell whether they were of the trifid or bifid type, or both nixed. 'There were eight lobes, the line of involution heing ocenpierl by a saddle.

The venter is capped by a hollow keel, as in movimexiramm, and in this species there is the plug, the dark layer, and an imner-shell layer, upon which the rentral saddles and lobes abut.

The sutures are more like those of novimexicanum than any other species, and I at first considered this to be the roung of that species; but the difference in these and in the extermal chancters at the same age are far ton marked.

The saddles and lohes are all shorter than in novimexicanum and overlap a trifle only from the fourth lateral to the umbilicus. Ther are also much less complicated in outline or less cut into by marginal hobes, and less distinctly phylliform.

The roung in section, so falr as seen, slowed the same general development as in Sphenodiscus, but the division of the primitive first laterals took place early in the neanic stage.

The figures (Pl. X, figs. 10-21) give the stages as far as these could be studied. The protoconch is stout and slightly scaphitoid or irregular in shape, like many other Cretaceons forms 'The second suture had a minute siphonal saddle that was distinctly seen by a side light. Fig. 11 shows the deepening of the antisiphonal and the begiming of the two first dorsal saddles on the first quarter of the second volution. Fig. 11a shows the lengthening of the antisiphonal, the incoming of two saddles and the beginning of a third on the dorsmm, the incipient stages of division of the primitive secourl lateral into four saldles of the anxiliary system and the arising of the serond lateral saddle on the inner side of the primitive tirst laternl sadrlle. Fig. 12 shows the progressive lengthening of the antisiphonal, the presence of a third pair of fully developer sarldles on the dorsum, the division of the primitive second lateral into four, the definite separation of the second lateral sarllle, and the incipient stage of the preat inner branch of the first lateral saldle: also the first appearance of the smalles" maromals on the onter side of the base of the same 
This specimen, therefore, affords clear ideas of the mode of development of the full-grown sutures in this form and also in the group to which it belongs.

Loculity: Near Carthage, N. Mex.

Age: Colorado gromp, Upuer Cretaceons.

\section{Collopor'ekas notmexicanim 11. sp. Hyatt.}

Pl. X. figs, 1-t.

This species appears to be more like Siplemortiscus lenticularis Meek than any other at first sight, but the sntures and other characters are so dissinilar that this impression is easily corrected.

The east in hand is $93 \mathrm{~mm}$. in diameter and, allowing for sipluncle om one side and crests on both sides, it would be, when perfect, alyout $96 \mathrm{~mm}$. The transverse diameter of the outer volution is $56 \mathrm{~mm}$., the umbiliens is about $1.5 \mathrm{~mm}$., and the outer volution below on same line is $34 \mathrm{~mm}$. without siphuncle and crest, which would make it with both about $35.5 \mathrm{~mm}$. The transverse diameter, about the middle of the lateral zone, is $23 \mathrm{~mm}$. for the largest, oldest part of the volution and $15 \mathrm{~mm}$. for the smaller, younger part opposite this. The latter had the shell on both sides, and deducting this it wonld be $14 \mathrm{~mm}$.

While the form and aspect were the same as in most other species of this genus, it has very faint fold-like costae on the onter part of the last half of the onter volution and more decided and more fold-like costations upon the younger portion and on first quarter of the exposed volution; these last reach to the umbilical shonlder.

The venter is subacute, with blunted, narrow arest, and on either side of this lateral zones are slightly concave on the entire onter volution. The shell vaulter orer a clear space above the siphuncle, the loollow keel, and this was filled by clear, erystalline limestone different from the matrix, and there was a black layer over the siphuncle. Farther ont al part of the black layer was foumd to consist of black dendritic oxide of irom. The sutures are equally peculiar. Upon eloser examination it is seen that the resemblances to Placenticerts are due to the small size of marginal saddles, the solidity of the fourth lateral saddles and the greater complication of the smaller sudlles than in sphenodiscus. There are, howerer, but two 
secondary lateral saddles, although the deep division and length of the inner branch of the first laterals make apparently three saddles. The onter branch of the first lateral saddles is narow, long, much cut up by marginal lobes, bificl, and las phylliform elongated marginal sadhles. They slightly overlap the branches of the ventral lobe, except in the two sutures figured. A large marginal springs from their orad parts inward, forning a narow saddle with phylliforn single base, mulirided on the younger parts of the volution and begimning to lave a small lobe on onter side in older parts of same. These are nuch longer than in colleti, are attennated and cut into by marginal lobes, and would usmally be counted as the second laterals. They do not reach to the next sutmres and are separated by bare spaces from the outlines of the second lateral lobes. The pointed aspect of the marginals is noted in PI. X, fig, 4, but the slightest abrasion would obliterate such marks and make all the marginals appear to be rounded, as they did to me at first.

The second laterals are nearly all on a level with these immer branches of the tirst and hare solicl elongated bases, which are cut inte only by suball pointed narginal lobes and consequently subphylliforn, but apicad of these there are on each saddle two projecting phylliform branches. The third laterals, first anxiliaries, are fully one-third longer than the second and broad and solid throughout: the apical openings are not contracted, their narginal sardles and lobes being small and short. The extraordinary length of these saddles causes them to overlap the inner outlines of the third lateral lube so much that one is apt, unless aware of this, to confuse two sutures and consider this saddle short and broad. The remaining saddles decrease in lengrh to the umbilicus. The fouth are like the third in aspeet: the fifth are slender, phylliform, and bifid; the sixth are slenter, single, and phylliform; the seventh less elongated, less slender, but phylliform, and near the umbilical shomlders. On the umbilical zone there are two rows of saddles visible on the last part of the outer volution, having still the rounded phylliform bases of the Sphenodiscus type. The siphomal saddles are quite distinct, larger and more prominent and unlike those of any other allied species.

The ventral lobe is similar to that of Sphenodiscus lenticuluris, but las spreading trifid arms. The first and second lateral lobes are narrow. The first is decidedly bitid, the second is but a shade longer than the first, and 
the sutures have to be perfect to see this clearly. The third is about one-half the length of the second, and from this one the decrease in length is gradual to the lines of involution. The third, fourth, and fifth lateral lobes are hroader in proportion and correlate with the forms of the accompanying saddles. There are eight lubes and nine saddles on the whest pirts of this rolution, the seventh lobe being on the unbilical shomlder.

The septa are concave along the median plame, being convex only at the ventral and antisiphomal lobes. The large third saddles, the first of the anxiliary series, correspond to the first pair of dorsals and are connected with then so that the number of saddles on the dorsm is the same as the number of lateral saddles, or six, exclusive of the sardle on the line of involution. 'The details of their enrves conld not be seen.

Locality: Near Carthage, N. Hex.

Age: Coloradro group, Upper Cretaceous.

\section{Collopoceras springeri 11. sp. Hyati.}

Pl. XII. figs, 1-3.

This superb specimen, presented to the Ifuseum of Comparative Zoology by Fuank Springer, of Las Vegas, the well-known student of crinoids, appears to have eharacters so distinct that they can not be accomted for by the extreme size and age of this specimen. it is 400 num. in diameter. The last part of outer volution from lines of involution to renter, which is slightly truucated by abrasion, is $225 \mathrm{~mm}$., and half of a volution younger it is $196 \mathrm{~mm}$. 'This, judging from thickness of the shell on younger part (5 $\mathrm{mm}$.) and siphuncle at this part $7 \mathrm{~mm}$. in dianeter, las lost 12 to $15 \mathrm{~mm}$., ant to this nust be added shell in the umbilicus, which was is $\mathrm{mm}$. At the last part of the second guarter of this solution, where sutures were studied, the rolution was $195 \mathrm{~mm}$. in breadth; the allowance of $5 \mathrm{~mm}$. fir shell on venter and of $3 \mathrm{~mm}$. for shell in umbilicus makes the rolution when complete $203 \mathrm{~mm}$. The actual measure of sante dianeter near beginning of first quarter, which was entirely covered by shell, was 14 !) $\mathrm{mm}$. The inner layer of the shell was not present in unubilicus and probably added 2 min. to this measmement.

There is only a small part of the living chamber left on this large 
specimen, and its original length is nut clearly indicated by any marks on the exposed rolution. The shell is only partly preserved, but it is sufticient to enable one to state that there are no tubercles nor distinct costax on either shell or east.

The venter is subacute and appeared at first to be solid, lout close examination showed a suall core of light-colored filling and a fine clarker laver between this and the large siphtuncle. 'The small size of the core was due to the great age of the specimen, and probably at a still older age the keel was entirely solid. 'The last part of exposed rolution is obvionsly in the extreme gerontic stage, since the line of involution has retreated considerably from the previous nomal line of involution, beginning its departure on the first quarter and thus greatly enlarging the dianeter of the umbilical opening. The diameter of widest part is $411 \mathrm{~mm}$. without the shell; with the shell it was $8 \mathrm{~mm}$. less, whereas that of the opening in next imer volution was only $10 \mathrm{~mm}$. with the shell on. The oldest sutures were closer together, and, like the decrease of involution, indicated that the specimen was outgrown; but these did not show the extreme degeneration sometimes found at the end of the pragremntic substage. 'The sutures an last half of the exposed rolution were not in good condition and these described below were about the middle of the rolution, or in what I took to be the metagerontic substage. The sutures were at this tine separated by a good interval, the first orerlapping being hetween the fourth saddles and the inner side of the third lobes. The next overlapping was between the seventh saddles and continned thence to mubilicus. The first lateral saddle on left side is very broad and of the trifid type, and the marginal saddles elongated and phylliform in outline. It has an inner branch which is phylliform, and although it might he reckoned is the serond lateral, is only a marginal, as in other forms of this genus. The corresponding nurginal in norimericumum is smaller, and is not at all likely to be mistaken for a second lateral saddle.

The serond is somewhat larger and less phylliform than this branch of the first lateral, but has similar characters. The third is still longer and larger and has lost more of its pliylliform aspect through the development of the long marginal lobes. The fouth saddle is very long and large, rising above the level of the first laterals, and is deeply cut and unsymmetrically trifid, each branch being subdivided except the central MON XLIN-03-7 
one. The remaining saddles are very short, broad, and more or less phylliform. The fifth is entire with exception of minute marginals; the sixth is trifid withont secondary marginals; the seventh and eighth are unsymmetrically bifid; the ninth and tenth are entire and phylliform. The eleventh saddle passes across the lines of involution and forms the seventh saddle of the dorsum. The corresponding saddles on the right side are quite distinct in detail, but of the same number and similar in general aspect. However, the fifth and sixth laterals are unsymmetrically trifid with secondary marginals, showing that they were on the road to the (puadrifid type, and the seventh is bifid. The remaining saddles are shown on the same side at an older stage. The eighth, ninth, and tenth were phylliform and entire; the eleventh. was entire, and situated on the line of involution. The lobes on the left side were as follows: The first laterals were merely marginals on the first lateral saddles, the first corresponding to the first saddle, as reckoned above, the second and third progressively deeper. The third, although it was apparently trifid in type, was subdivided by a very long, slender, and peculiar marginal saddle coming from opening of fifth lateral saddles. The fonth, fifth, sixth, and seventh laterals were broad at the tops and had pointed small marginals as in some other more primitive species. The eighth, ninth, and tenth had more mequal serrations and were narrow at the tops.

The adult sutmres were exposed on an inner volution and exhibited, as I anticipated, more overlapping than in the gerontic stage, owing to the greater length and development of the second and third lateral saddles. This is an instructive case becanse, as a rule, the overlapping is greater in the gerontic stage than in the ephebic. In the extreme gerontic stage, when the decrease in length of the saddles and lobes is greatest, the approximation of sutures causes overlapping, notwithstanding this decrease. But in a prolonged gerontic stage the relative decrease in length of lobes and saldles may sometimes, as in this case, where septa are not much closer, cause sutures to appear wider apart than in the ephebic stage.

The adnlt sutures had very much the same outlines as in the gerontic stage rescribed ainove, but there was a slight overlapping along the entire suture.

"This shows a variation between the two sides that is interesting, and it must also be noted that there is a slight overlapping on this side, owing to the greater length of the fifth and sixth saddles. 
There were three prineipal lateral loves and the third was the remnant of the primitive lateral lobe.

The dorsal sutures were seen in the gerontic stage and a partly restored outline of the antisiphonal is given in Pl. XII, fig. 3. The right outline and the end of the lobe are restored. 'The extrene bifid end of this lobe was, however, seen from below. The first dorsal saddle was clearly seen but was apparently abraded like the antisiphonal, and the remaining saddles were seen, but not in such comnection as to make a drawing desirable. They correspond in outlines to the opposite lobes and saddles of the auxiliary series, being entire and phylliform near the lines of involution and trifid near the first pair of dorsals. The lobes also are digitated like their opposite companions of the anxiliary series. There are six pairs of saddles, with a seventh continnous with the eleventh outer saddles, and six pairs of lobes, the antisiphonal making the thirteenth lobe on the dorsum.

Locality: Rit du Plain, Colfax County, N. Mex.

Age: Colorado gromp, Upper Cretaceons.

\section{Collopoceras requienianum (d'Orbigny).}

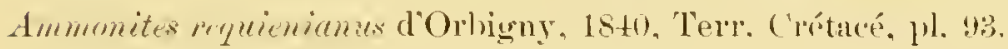

The suture given by d'Orbigny las a large first lateral, but it is narow, long, and bifid, with a third arm on the external side. The two nexf sadelles have the relations common in this genus, the second being hardly distinguishable as an independent saddle, narow, phylliform and bifid, while the third, which is large enough to be ranked as an independent saddle, is narow, jhylliform, and trifid. 'The auxiliary series has the broad complex saddle to begin with, reckoned in these descriptions as the fourth lateral, and the remaining sardles have the usual phylliform bases, all that are drawn, four in number, being bifid.

The outlines approximate more nearly to those of the phylloceran group like Aconecerus misum. The siphonal saddle, if correctly drawn, is interme diate in aspect between the broad rentrals of other speries of this gemus and those of such forms as Platylenticeras heteroplemm, with narower siphonals.

Locality: Uchaux, France.

Age: Turonian. 
Collopoceras? grossotrrei 11. sl. Hyatt.

P. XII. fig. 7 .

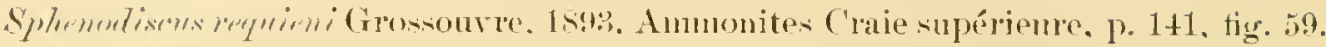

The sutme and description given hy Grossonver of his French species and the one figured hy d'obbigny as Ammonites requirniames, althomgh quoted as identical by him, are very different. 'There are distinctly three principal lateral saldles in Crossonve's figure, but the first is linge, long, and trifid insteal of being narrw, long, and bifid; the second is really an enlanged brande of the first sadrlle and still entire, while the thind is bifid and

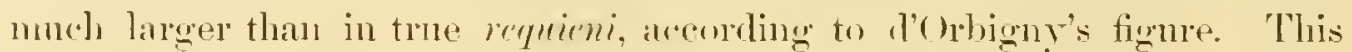
secies may he one of the hollow-keeled gromp, a sngestion that is further supported by the aspect of the anxiliary saldles and lobes. In order to call attention to these points I have placed a question after the generic name.

Lorulity: Near Tours, Fance.

Aye: Thuonian.

ACUNECERAS ${ }^{*}$ и. gen. Hyatt.

The single species here referpen to this gemus lias sutures more like those of Cretaceous foms of Phyllocelatida than any othels of this group. These are combined with a highly involute compresserl shell having an ax-like acute venter like a species of Eulophoreras. The rentral sadelle, as figned hy arobigny, is broal and similar to that of Coilopoceras: the first lateral and the other saldles are deeply divided and broader than in the Phylloweratila and certainly show approximation to those of the Coilopoceratida. I have therefore refered the form to this family, and it appears to strengthen the opinion that the Coilopoceratida were derived from the l'liylloceratilae.

$$
\text { Aconeceras xistm (d'omigny). }
$$

Iア. XII, tig - t-ij.

Ammomites nisus dorhigny, 1st1). Terr'. ('rétace, pl. 55.

This figure is copied from d'orbigny becanse it gives what appears to be an inportant link in the eviflence that the group to which it is refermed is correctly refered to the lhylloceratida."

Age: Neocomian.

"Akóv?, a whetstone.

b. The twu pages of manuscript bearing these notes on . Icomereros were out of place, lying at the top of one of the two bundles of manuscript, and just hefore the generice name is the penciled note, 


\section{COAMIOCHRATTDA.}

\section{ThCOCERAS Choffat.}

This genus, thanks to the researches of Choftat, ${ }^{b}$ "an now perhaps be asigned to its jooper group. In my chapter on Ceplablopols in Zittel's Text-lwok I plared it with a question mark in the Aranthoceratida. It is apparently a gromp of rely boal amonate shells laving in the voung ardulescent stage of some primitive forms (ex. I. subconciliutum, ('hoffat) three rowrs of tubercles, which are often large nodes on casts. The section is essentially hehmet shapeet at this age, the umbilical zomes very abmpt,

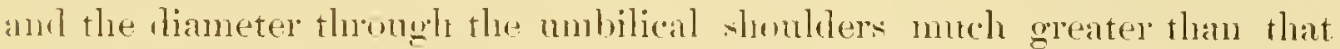
thungh the ventro-lateral angles. The absende of a keel and the rounded verntral zone, interupted hr costa in some forms, are characteristies that, twethether with the lateral nodes and section, are similar to the young stages of Conomites and the discoidal forms of Hoplites that lave sinilar coronate young with a line of linge noles. 'The sutures lave remarkably broad first latera] saldles and ventral lohes that are similar to those of sume species of

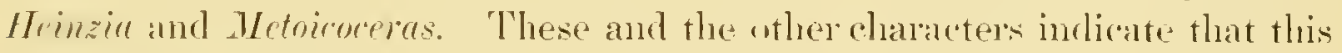

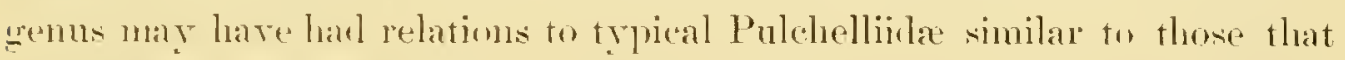

"belongs with the Desmomms grunf." It seens prohable, therefore, that Professor Hyatt barl rhanged his opinion concerning the relationship of the genns, fut as he lat arranged figures of it on the plate in connection with figures of coilomeres, it is thought bent to frint the manuscript as written. The statement that "the group * * * is correcty referren w the Phylloceraticla" is evidently in conflict with the general note on the Mammitica, which is male to include the Coilopoceratida anl many other lamilies. I have nut been ahle to deternine which of these views was last lelı hy l'rofessor Hyatt, but the arrangentent of the mantuscrift gave the impresion that .leonecerus was remover from Coilopweratice as the result of later studies and that much of the evirlence for the relationship of the family with Phylloceratica was thus removed, - T. W. S.

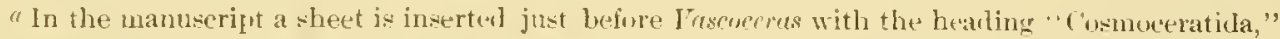
followeel by. "In fanily deseription notios restembiance of form to Aspiloc. of Jura as more remote

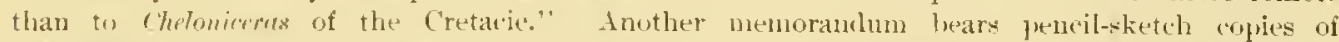
l'Orbigny's figures of thmmmites royriunns (Pal. Fr. Terr. ('ret., 1, 11. 112, fign. 3, 4) labeled Chelonireres royericmus, indieating that he had probably selected this species as the type of a new genus. It in inferrel from this that he hal referrerl leseocmes the cosmoreratida, and that he

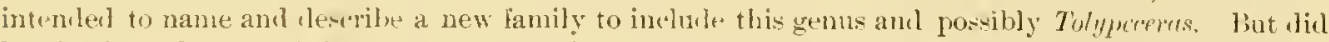

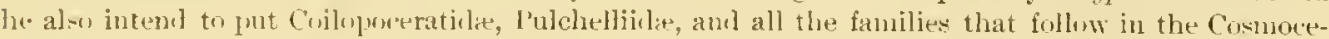
ratida? I can see 110 evidence of it, except in the arrangenent of thr manuseript anit the absenee from it of other super-fanily names. Certainly no justifuation for it can be found in the lefinition given ly Profesenr Hyatt in Zittel's Text-honk. In the plates Fasmomes follows Coilopeneratidie, and I have changerl the arrangenent of the manuscrijt sheets as foum so that the descriptions follow in the same writer, believing tlat this is a more natural oriler and that it represents I'rofesor Hyatt's latest views, as the last work he rfid was the momnting of these llawings in plates.-T. W. K.

"Faune Crit. du Portugal. 
highly coronate forms like Erymmoceras in the Inferior Oolite have to true stepheoceras, but mutil the young are known there can be 110 certainty in such conclusions.

The similarity of this genus to Olcostephlmus is very close indeed. The costre on the venter of that gems are, howerer, not so fold-like, and the nodes on the unbilical sloulders are correspondingly smaller and more numerons. The sutures in Olcostephomus are much more complex in outline, and there are fewer saddles and lobes.

The coronate form of the volutions and deep open umbilici retained in some untuberculated shells lave a certain remote resemblance to some forms of Pachydiscus, but, so firr as I know, none of these, nor any species of Cretaceous Ammonitinx, have volutions so excessively depressed and so similar to the Stepheoceratide of the Jura and some Goniatitine of the Carboniferous.

The living chamber is full three-fourths of a rohtion in length. Lateral zones do not exist, the umbilical zones being abrupt and the umbilical shoulders on the lateral edges of the venter.

The only form in the Cretaceous that is similar to this is in the young of Gablinoceras butesi (Gabb). This last has a similar coronate form without any literal zones thronghout the neanic stage, but the sutures show this to belong to a different suborder, the Leptocampyli, with which it also agrees in the aspect of the shell and the characters of the adults.

The sutures have rery peculian broad, short rentral lobes and first lateral lobes. There is but one broad principal lateral sadille, with coarse marginal saddles; the lobes and saddles are ammonitic-that is, completely margined by small lobes and saddles. White's figure has the sutures very imperfect and much worn away, but shows the orad trend of the auxiliaries. It is also defective in regard to the first anxiliary saddle. This is a welldefined and very hroad saddle, smaller than the first lateral, but otherwise resembling it. 'The sutures are considerably worn away in the specinten figured, but the preservation is better than in White's fossil. The differences in the sutures and form from its assumed congeneric associates in the Pulchellidar can be accounter for if it is assmuned that this genus is in its principal characteristics an arrested development of the coronate form of the early stages, as stated in the introduction to this paper. 


\section{VASCOCERAS haRTTi (Hyat)}

P'. XIV, tig. 16.

Ceratites harttii Hyatt, 1870. Geol. and Phys. Geog. Brazil, p. 386.

Buchiceres harttii Hyatt, 1875. Proc. Boston Soc. Nat. Hist., Vol. XV11, p. 370.

Ammomites herttii White. 1885, Areh. Mus. Nac. Brazil, Vol. VII, pl. 19.

Faxcocepres? hurttii Choffat, 1s9s, Fame Crét. du Port. Vol. I. 2d series, pl. 13.

This fine fossil was receired from Prof. J. C. Branner, and was collected by him not far from the locality of White's fossil of the same species. It is a cast, the diameter of the whole is $175 \mathrm{~mm}$., the transverse dianeter of the last volution is $124 \mathrm{~mm}$. The form and general aspect is about the same as in White's figme; living chamber of the sane length-three-fourths of a volution-and also other extemal characters and sutures are as rlescribed in remarks upon the genus; the imer rohtions could not be exposed. There is not the slightest fragment of shell upon this cast, but there are the remains of the cemented valves of two or thee ostreans. With reference to these I again reiterate the opinions expressed with reference to Hartt's and White's specimens. This east must, like these, have been a fossil at the time the ostreans were building their shells, since their valves are attached to the surface of the cast and fit into the inegularities produced by abrasion before they began to grow on its exposed surface. It was not a nember of the fauna in which they were found, but came from some earlier strata.

Locality: Province Sergipe, Brazil.

Age: Cenomanian?

TOLYPECERAS ${ }^{\alpha}$ n. gen. Hyatt.

The curious species upon which this is fommled, Tolypeceras (Amm.) murousmum, described and figured by Pictet and Campiche in their Terrains Crétace's de St. Croix, is represented in the collections of Mnsem of Comparative Zoology by a fragment collected by Jules Marcou, near Nozery, in switzerland. 'This is, however', sufficient to enable nie to see that the sutures of a somewhat yomger stage than those figured by l'ictet and Campiche are of the same type as those of Lenticens, but with slorter marginals. The first lateral saddle is broad and solid and the other saddles are also broad and not deeply cut into. The outer volution is $22 \mathrm{~mm}$. in 
dianeter thromgh the nesal plane and 20 mun. at the boadest part between the moles. The next yommerest rolution is 9 mm. in rentodorsal dianeter and !) num. Horod.

\section{BARROISICERAS Gmssumre: ${ }^{a}$}

According to (xossonve's and hedtenbacher's tigures this gemus evidently has smoth, complessed yomng, witl a continnoms keel. Grostomve shows some forms internediate hetween those of his involute haberfellneri and the rery discoilal mes figured by Redtenbacher. It is very otwions that these have mo attinities with Tissotia, mless it may be thromgh the sinnilarity of the vomeg. 'The voung in this and in Tissotia sugests aftinity with the so-called Orynoticeres of the Cretaceons figmed by Semmrer. Aplarently the yomng tigured hy Redtenbacher in more involute than at later ages.

The metamorphoses seen to be (1) entire keel, sides smooth, renter acute, and form involute; (2) costated with entire keel: (3) tuberculated and costited and keel broken up into tubercles ly crosing of renter by costie; (4) continuous keel anain. (See Redtenbacher, An. Piion., Abhandl. K.-k. geol. lieichsinstalt, Tol. V, 1873. pl. 23, tig. 3 b, d.)

'This group, so fully described by Grossonve, contains an excellent series of forms which he largely inclules under the single name of $B$. lube'rfellnevi. Aconding to the mode of classification followed in these pages, the great differences in form and other characters, inchuling comesponding differ-

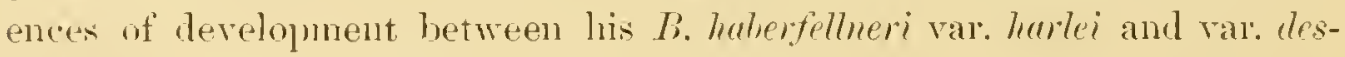
monlinsi, indicate distinet species widely remored from each other. It makes no difference in following ont this methol whether these are olviously commeted by intermediate forms or not, the sole criterion being whether the species differ in their form, involution, and other characters sufticiently to be arangerl in a natmal series which can be sloww to be parallel or partly parablel with other generic groups about which there is more complete information.

This genus is refered to Mammiticie in Hyatt's wayter in Zittel's Text-book, while in the

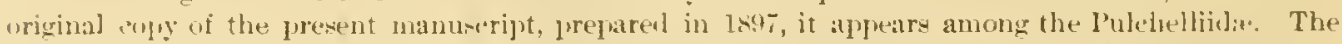
nuts: on the Pudchelliclat then written are entirely sujerseded hy the pages in Professor Ilyatt's handwriting puldished here, in which the tamily is nuch restricted and iloes not contain Barroisicera*,

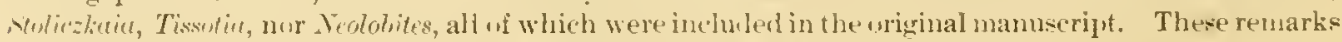

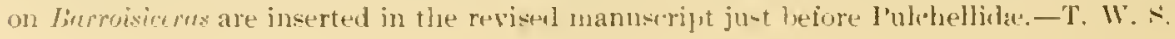


BarRoIsiceras desiotlinsi Cirosionve.

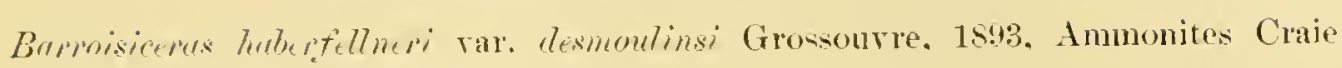
supérieure, pl. 2. tịg. 6.

A very stout form, with huge nodes and having the continuous keel until a later stage.

Locality: Near Périgueux (Tordogne).

Age: Coniacian.

BarRotsiceras hateri n. sp. Hyatt.

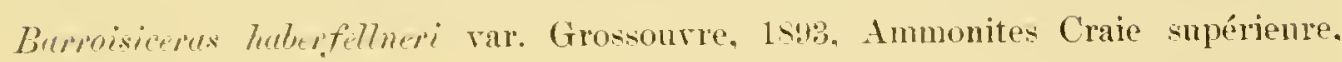
pl. $2 .$, fig. 1 only.

This is more compressed than B. desmoulinsi, the notes are smaller and more mumerous at the same age, and the keel is broken up into tubereles.

Locality: Same as above.

Aye: Sime as above.

\section{MANTELLICERATIDA.}

\section{MANTELLICERATIDA.}

This group was described in Zittel's 'Text-book, Cephalopoda, page 587, as the Pedioceratida, and included only the genera I'edinccras, Douritleiceras, Strumoreras (Odoutoceras) Cossmann, and Liadochoceras. Of these, Stemorevas shomld be remover to the Hoplitidae. In the young, ar throughout life in primitive forms, there is close parallelism with Phirodoceres and other discridal tubereulated forms of the Cosmoceratide, but in later stages the large single or imperfectly bifurcated costre eross the venter. All traces of tubercles may be lost at this or a later age in some forms, but in most species there are at least two rows, one on each of the rentro-lateral angles. There is never at any stage a row of median ventran tubercles $110 \mathrm{r}$ a keel, ${ }^{2}$ nor are the ventral costre ever cut through by a narrow rentral chamuel, as in Hoplitidx.

"Acomprocerva apwears to be an exception in the figure given by schluter, but that author distinetly states that no true keel is formed. 
METASIGALOCERAS 1 , gen. Hyatt.

The type of this genus, Metasigaloceras rusticum (Sow.), has been figured by several autlıors." All of these figures, including Sowerby's, show a form in section like that of Sigaloceras taylori and two rows of large tubercles. These are, howerer, not truncated on the casts as in that genus, but are apparently hollow spines arranged in two outer lines. There is no inner line of tubercles. There are the same number of lobes and saddles on the sides as in Sigaloceras, viz., three broad and rather deep, solid saddles with corresponding large lobes. The sntures, as figured by Sharpe, are sufficiently similar to those of other genera in the family Mantellireratidae to show that it can readily be placed in this group. The first lateral saddles have three long branches, the second lateral is rather narow and, although well divided, is club shaped, and the third is broad and leeply bifid. This outline is more like that of Dowvilleiceras than any other genus. The dorsal sutures conld not be compared. The alternating costre are tuberculated on the renter of Pseudaspidoceras and smooth in Sigaloceras. The general resemblances to Aspiuloceras are apparently close, but as this genus has no imner line of tubercles and perhaps no strongly dereloped lateral costations at any stage, the comparison fails. It is obviously a more prinitive form than that of Isendaspidoceras or Dialochoceras.

\section{PSEUDASPIDOCERAS n. gen. Hyatt.}

This genus is instituted for some Indian fossils which in the adult forms and ornaments of some species show close parallels with Jurassic Aspidoceratida, but the development and sutures place them in the same family with Liadochoceras. Their forms are discoidal with quadrate volntions, hroal concave venters, flat lateral zones or sides, prominent umbilical sloulders, and distinct convex, smooth umbilical zones. The costre are wide apart, cross the renter and have two ventral and at least four lateral rows of tubercles, two on either side. The young have in the type form Psemdaspriloceras footeamu (Stoliczka), stage similar to that of Diadochoceras norlosocostatum with, however, more prominent alternating costre and more quadragonal form of whorl.

"Amm. rusticus Sowerby, Min. Conch., p. 177; Amm. rusticus d'Orbigny, 1840, Terr. Crétacé, pl. 111: Amm. rusticus Sharpe, 1856, Foss. Moll. of Chalk of lingland, pl. 20 .

"Foss. Ceph. Cret. Southern Imlia, pl. 5:3. 
Other species of this genus are as follows: Pseulaspidoceras (Amm.) conciliatum, cunliffi, and perhaps crassitesta Stoliczka; also Pseudasp. (Amm.) enomphatum Sharpe, and decidum, equal Amm. rotomagensis d'Orbigny. There is also a stonter species from the same locality as the last, Rouen, which las the ventral tubercles in close approximation and a much more aspidoceran aspect than in the usual form. This is Psendasy. schlüteri 11. sp. Hyatt (Amm. rotomagensis Schliiter). ${ }^{d}$

The fact that this species and Metacunthoplites rhotomagensis (Defiance) which has a line of median ventran tubercles and a distinct mole of development, have been so often published under the same specific name is very interesting: It shows low close is the parallelism of form between two widely separated genera, one in the gromp Cosmoceratida and the other in the IIammitida.

\section{DIADOCHOCERAS Hyatt. ${ }^{e}$}

The young of this genus, first citexl in Zittel's 'Text-book, page 587, has in its youngest stages a more eylindrical volution and more distoidal form and slower growtl than in Dowitleiceras. The paranepionic stage has a coronate form with large tubercles and smooth sicles, as seen from the umbilical aspect. At this stage the venter could not be seen. Later lateral costre appear and a line of very small tubercles at their inner ends. In the neanic stage there are ventral tubercles sitnated on the larger costre and a brond depression oceurs between them on the continuous costa that cross the venter. This depression is not at first present in the intermediate nntuberculated coste, which are continuous laterally and ventrally. Later in the ephebic stage the intermediate costie disappear on the sides but remain on the venter and becone dichotomous from the lateral row of tubercles of the larger costations. This may be a matter of individual variation or it may be characteristic of different species, since in d'Orbigny's figure (Terrain Crétacé, pl. 75) it is not present in the adult, and two specimens that I have handled of the type species, Dind. nodosocostatum d'Orb., differ, the costa remaining single in one and becoming dichotomous in the other: There is also a third row of tubercles developed in this genus on the umbilical slwulders that is not present in Douvilleiceras until a later age, when the associated characters are quite distinct.

"Foss. Ceph. Cret. Southern India, pls. 50-52.

2 Foss. Molt. of Chalk of England, pi. 13.

cTerr. Crétacé, pl. 106.

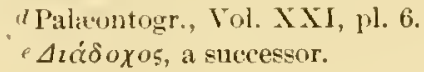




\section{PEIIOC'ERAS Gerhardt}

Trpe Perl. cundinamancer, Geriandt Kreideformation in Columbien, etc. Neues .Jahrb. für Min., Geol., und Pal., beil.-Bil. 11, 1897-98, p. 172, pl. 4, fig. 7. Age Aptian. A stout, quadragonal, rery discoidal shell, with two lines of nutel tubercles and one on the unbilical shoulders, all very slight, costre linear, bnt prominent on the sides and crosing the venter, which is broal and concave. The dorsal side barely rover's the onter line of tubercles. No sutures given. Inchudes rnyesensis and ubaquensis Karst.

\section{bOUTILLEICERAs Crossouve.}

The type of this genus is the fossil figured tirst by Walch in the Naturforscher, Vol. I, 1774, p. 196, pl. 2, fig. 3. This was cited by Schlotheim in his Beitrage zun Naturgeschichte der Tersteinerungen in Taschenbuch für Mineralngie, Jahr: 7, I, , 111, as the trpe of Amm. mammillatus. 'The figure given by Walch seems to apply to the young of the form usually cited by anthors as mammillaris and figured by d'Orbigny under this revised name. Mammillaris is cited by Grossoure, withut an authority after the name, as the tyo of his genus Hourilleiceres in lis Ammonites de la Craie Supélieure, page 26 , and the sutme alone is given m page 23.

The romug of the shells in the genus have after the smooth nepionic stage highly coronate depressed rolutions with lorad smonth renter and a line of spines on the rentro-lateral angles. These are at this time coincident with the umbilical shoulders, the true sides of lateral zones being of later age. The umbilical zones at this time are broal and smooth and convex, reaching from the tubereles to the lines of involution. Faint costre are developed from the tubercles in both directions, completely crossing the renter, and shorter ones on the sides. They appear also to be dichotomons at the mbercles. Later these large tubercles separate more widely and intermediate costa begin to appear, apparently thromgh arrested development of some of the tuberculated custa already existing. These lave the same form and tubercles, but are less promment than those on either side of them, and sometimes this is carried to the extent of suppressing entirely the alternate pairs of tubercles. During this stage the lines of ventral tubereles appear, and those may be, but are not always, smaller m the alteruating costae. Subsequently at smme stage the smaller costa and tuhereles becone of equal size with the others. The stage with four lines uf tubercles may persist milil the shell is one-halt to five-eighths of an inch 
in diameter, but usually another line of minute tubereles appears on what are to become the umbilical shoulders, and lateral costic and a lateral zone begin to appear. 'This oreurs before or contemporanconsly witl the appearance of another line of tubercles on the ventral costa cluse to the already existing rental lines. In the next stage a third line appears on the venter next to the last developed, and usually nearel to them than to the ventro-lateral line of primitive tubercles. It or abont the same timu still another line of tuherches aplears on the lateral costa midway between the two lateral lines. This stage of twelve tubercles is succeded by a fourteen-tuberculated stage, and in some anses by a sixteen-tuherculated stage, through the generation of arlitional lines of tubereles on the venter. During these later stages the form of the volution changes, losing entirely its commate atspect. The venter hecomes more and nome elevated and lounded, the costax more juminent, and the tubercles are apt to become more and more equal in size, so that eventmally in some speceses it is difficult to pick out the primitive lateral tuhercles. The stage of neanic age, in which there are six lines of prominent spines, is exactly similar to the

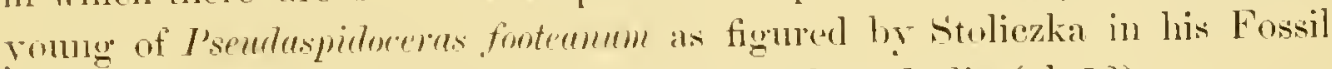
Ceplatopods of the Cretaceons Rocks of Southern ludia (pl. 52).

'This genus includes the spreres described below.

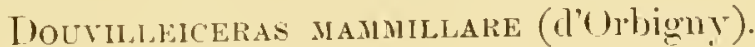

Ammonites mammilluris dOrhigny (pars).

Assuming that the roung of d'Mbigny's species on pl. 72 represents the mammillatus of Sehlotheim, it is evident from the conllections in the Museum of Comparative Zoology that his supposed mammillaris given on pl. 73 is a distinet species. The young lave the same croweled roste and aspect of this species only thonghunt the neanic stage. In this species this crowded condition of the costix and the development of additional rows of crest-like tubercles on the renter seem to continue indefinitely. In some specimens that can havdly be comsidered as anytling more than sporadic varieties, there are one or two aditional lines of tubereles generated within the ventral chamel, and in on shell a line of faint tubereles finally appear in the midule of this channel, thus initating transiently the olnamentation of a distinet family, viz, the Mammitida.

Locality: Cherbume, St. Croix, ete.

Age: Albian. 
Dotvilleiceras orbigrit 11. sp. Hyatt.

Ammomites memmilluris d'Orhigny (pans), 1840, Terr. Crétace, pl. 73 (not pl. 72).

Thromgh the neanic stage this species is not separable from mammillare except by its slightly more discoidal form and nore prominent tubercles on the venter, but later than this the costre separate as given in d'Orbigny's tigure, though the nonderelopment of intermediate costa. This gives an entirely distinct claracter to the manentation. One fiagment from Cherbonry, in the Konincek collection in the Museum of Comparative Zoology, shows perhaps a third species, since this change is much more pronomeed than in the type cited above and necurs at an earlier age.

This genus is representerl in Nortl Anerica by Ilowv. (Aconth.) spinifrum (Whiteaves), found in Canada, and there seem to be two species, the first described in Mesozoic Fossils, Tol. I, pt. 1, pl. 4, and the second in the same, pt. 4, pl. 35. The differences appear to lie in the costations and tubereles of the older stages.

Localities: Numerous, westem Europe.

Age: Albian.

\section{SCHLUETERICERAS ॥. gen. Hyatt.}

'This group, has in its trpe species Shlnctriceras notosoides, described and figmed in Schliter's Cephaloporlen der oberen dentschen Kreide (p. 18, pl. 8, figs. 1-4) a neanic stage with compressed, flat-sided, moderately involute shell that resembles the neanic shells of Metoicoceras and Mantclliceras in aspect and in the possession of six rows of tubereles and a concave, keelless venter. In the next stage, however, the ventral lines of tubercles are lost, thus reducing the shell to a quahri-tubereulate stage and nuch larger and louger norles and more prominent single lateral costa are developed, while at the same time the venter becomes flatter. This is a degencrative, obviously gerontic change, but it is so distinct from the similar stages of other genera that it is quite suffieient to characterize the group. It is from the Lower 'Twonian according to Sehliiter.

()ther species of this grenus are as follows: Schluetericeras vielbanci of the 'Turonian, lescribed and figured by d'Orbigny in Terrain Crétacé (pl. 108) as woolyari, but changed in his Prodrome (Pt. II, p. 189) to this 
nanne. The reference to this gemus accounts for the retention of two lines of obsolescent tubercles on the flat venter between the large ventro-lateral spines. Schluetericeras lanbei, described by Lanbe and Bruder in Ammoniten der Böhmischen Kreide ${ }^{a}$ as nodosoides of Schlizter, and Schlhetericeras michelobense occur in the Upper. Turonian and are distinct in their forms, especially their large norles and costre, and in their tendency to form definite chamnels on the venter, from either vielbanci or norlosoides

\section{SHARPEICERAS n. gen. Hyatt.}

This genus in its full-grown condition has very nearly the same form and characteristics as the neanic stage of Mantelliceras mutelli. There are eight lines of tubercles and the volution is compressed quadrate in section. 'The costæ, are however, more evenly developed and do not bifurcate in the figures given by sharpe. These characters are so marked and it is so plainly a plyymeanic form that it can not be placed in the same genus with Mentelliceres. Its claracters in old age are nnknown, but in the young, according to Shave, the costa are dichotomons from the line of tubercles on the mubilical shoulders.

Type is Sharpeiceras laticlavium (Sharpe), figured on pl. 14 of his Fossil Hollusea of the Chalk of England (Pt. I, pl. 14).

Sharp. schlueteri n. sp. Hyatt, described as Ammonites laticlavius by Schliiter in Cephalopoden rer oberen dentschen Kreide ${ }^{b}$ is a Cenonamian species with less rapidly growing and less compressed volutions than in the Finglish shell. Shurp. inconstens (Schliiter) is a more involute species of the same genus, haring in its old age, if correctly defined by Schlititer, a volution precinely similar to that of the gemms Acompsoceres. All of these belong to the Cenomanian

\section{ACOMPSOCERAS ${ }^{c}$ n. gen. Hyatt.}

The type of this genus, Acompsoceras bochumense, was described by Schliiter in his Ceplnalopoden der oberen deutsehen Kreide, "ifom the Cenonamian. In the adult stage, as described and figured, it has large fold-like costro on the lateral zones, with two rows of tubercles, one on the edges of a flattened venter and the other on the dorsal shoulders. These

a Palrontogr., Vol. XXXIII, 1887, p. 229, pl. 25.

$b$ Palieontogr., Vol. XXI, pl. 7 .
"'Akopфos, unadorned.

(Palæontogr., Vol. XXI, pls. 1, 2. 
are exactly like those of I'ulchellia. In the aspect of these ornaments and in the convex venter with its nascent keel or raisert line the re is also a close

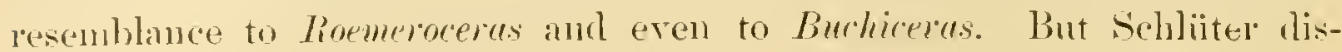
tinctly states that this is not a keed "und der Sipho driicks die Wittellinie

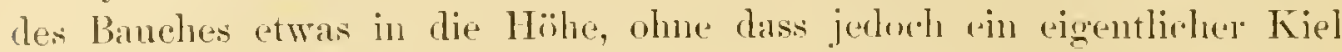
chitstinde." In ald age the sides beeme smooth and the renter rounded, and all traces of tuhercles and rosta are lost. The sutures have a decided similarity to those of shenpeiceras inconstens, and, as stated in notieing that species, the older stages of this speeies are similar to those of bochumense, while the yominger ones, inchuding the ephebic stage, liave the characteristies of Sharpeicerus. This implies genetic comnection with that genus, and if confined by further olservation, settles the origin of the group. The roung are not known, and mutil these are known it is, of connse, questimable whether the affinities for Sharpeicerus are an close as is assmmed here.

Acompsocerus essmense (Schliiter), described in the work quoted above, and also from the Cenomanian, is another species of the same genus.

$$
\text { Acompsoceras renevieri (Sharpe). }
$$

Ammentes renerieri sharpe. 1856. Fons. Afoll. of Chalk of England. pl. 20 .

This species is from the Gray (halk (Cenomanian) of England and has been referred to as sinilur to essemense. It is a more compressed form than either Acompsocerns bochmense or essendense, but las a nasecent keel and two rows of large tubercles, one on the ventral edge and the other on the umbilical shonlders which are similar. The tubercles are comnected by broal fold-like costere with intermediate shorter costations that sometimes bifurcate from the longer ones.

The sutures have a large, deep, and rather narrow ventral lobe divided by an entire siphomal saddle. The first lateral saddle has three large marginals, the first lateral lobe is long, rather narrow, aud hifid. There are but three lateral sandles, the immermost of good size and bifid. If this suture is correctly drawn by Sharpe, it is more like that of Burroisiceras as figured by Grossourre than that of Acompsocens. But until the young is known, the generic nane should be considered uncertain. The sutures also are not milike those of some species of the keeled anl tuberculated forms like coupei, ete 


\section{MANTELIICHLAS n. geen. Hyatt.}

At first sight the type of this group, Mentelliceres mantelli, appears to belong to the same gemus as Metoicorever, hut a slight examination of the development shows them to be generically separable. The tuberemated young Mantelliceras approximates to the type of development exhibited by Donvilleiceras, and is a compressed tachyenic form of the same fantr. The arult characteristics also show no close athinities for the Pulchellian gromp to whirl Metoicoceras probably helongs.

The trpe species can not frequently be separated from Calycoceres ${ }^{a}$ nuvicularis, owing to the similanities caused hy the contimuity of the costae acioss the venter and the presence of similar lines of rentral and lateral tubercles. The development, howerel, and the forms in well-preserved fossils are both distinct and their variations lead in different lirections. C. nucicularis las the coronate form polonged in its early stages and the costa prominent on the renter and a median ventran line of tmbercles during its neanic stage and sometimes later. 'The furrowing of costae on the venter is of hater derelopment, and if shape's figures and descriptions in Fossil Ifollus:al of the Chalk of England, page 39, pl. 18, are correct, it is dne to the disappearance of this line of tubereles. I have not been able to get the romug of this species for study, but that this line of tubereles is sometimes retainerl until bater is obvious in some specimens that I have had in land.

'The relations of the young to those of Inowilleiceras are obvious during the stage in which the vohutions have a very broal ventral channel, with costie crossing the renter and six rows of tubercles, and before the inmermost and eighth rows arise on the inner ends of the costre In the vetotuberculate stage they are like the full-grown form of sharpeiceres laticlucium. 'The shell of $M$. mentelli is at that time, a nirldle neanic suhstage, very clusely similar to Jourilleceras mammillatum in its sexituberculate stage. No additional lines of tubereles are added in this genus. On the other hand, the tendeney is towad complete suppression of all except the two rentral rows. These lisappear also in extreme age. 'The sutures are obvionsly of the same type as in other genelat of this fimily and are closer to those of Domvillowers than any other genus.

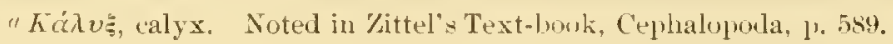

HOX XLH-113- 8 


\section{Mantelliceras Mantelia (Sowerby).}

Ammonites mentulli sowerhy, 1814, Min. Conch., pl. 55.

lmmomites mentelli Slarpe (pars.), 185t, Foss. Moll. of Chalk of England, pl. 18,

figs. ti, 7 (not fig. 4).

Immmites mantelli Schlïter, 1572. Palrontogr., Vol. XXI. pl. 5 (not pl. 6).

The compressed form, with hroad venter, and presenting clearly three facets, with four rows of tubercles, more or less well defined, is obviously the shell that more neally than others answers to Sowerby's description and finures. This is obvionsly the form that in the young is the least involute and hats the most decidedly quadragonal volutions, becoming compressed in later stages. This is the var. (a) of Sharpe, as quoted above.

\section{Mantelliceras colloxi (d'Orbigny).}

Linnumites mentelli d’Orhigny, 1840, 'Terr. Crétacé, pl. 104 (not pl. 103).

Ammonites comloni d'Orbigny, 1S50, Prodrome de Paléontologie, II, p. 147.

L Immonites mantelli Sharpe. 1856, Fosi. Moll. of Chalk of England. pl. 1s, fig. $t$ (not figs. 6, 7).

Ammonites muntelli schlüter, 1872, Palrontogr., Vol. XXI, pl. 6 (not pl. 5).

This is a highly compressed shell, separable even in the neanic stage from mantelli. The young are much more compressed than in mantelli, sides flatter, and the form resembling that of the full grown of that species when the shell is not over three-fourths of an inch, or about $18 \mathrm{~mm}$, in diameter. The tubercles are present, but much less prominent in the young than in matelli at the same age.

\section{Mantelliceras picteti n. sp. Hyatt.}

Lmmomites mantelli Pictet et Cumpiche, 1859, Terr. Crét. de St. Croix, p. 200, pl. 26.

The neanic stage, with its more compressed form, but otherwise like the young of mutelli, and all stages are finely illustrated by the authors yuoted above. The volutions are more compressed than in mantelli and somewhat less involute in all stages later than the neanic, and the renter narrower. The octotuberculate stage is more prolonged and the mubilicus wider than in $\boldsymbol{M}$. couloni. In extreme old age the tubercles are all lost and costie are prominent where they cross the narrow rounded renter. 'There are a number of this species and casts of some of Pictet's originals in the Hnsemm of Comparative Zoology. 
Loculity: St Croix.

Age: Cenomanian.

Mantelliceras vicinale (Stoliczki).

Ammumites ricimelis Stoliczka, 1865. Foss. Ceph. Cret. Southern India, pl. 4.

Loculity: India.

Mantelliceras ushas (Stoliezka).

Lummenites uslues Stoliczkil, 1865 , op. cit., pl. 51.

Locality: India.

Mantelliceras indanense Hyatt.

Ammonites mentelli Stolička. 1865, op. cit., pl. 41, 42.

This species is similar to true mantelli, but the shell retains the eight rows of tubereles and the facetted form until a much later age. It finally loses these larval characters and takes on the usual aspect, with only two rows of rentral tubercles and compressed volutions. There are probably two species under this name. The type of this is fig. 1, pl. 4.2, a more ornate shell than any variety of montelli, with larger tubercles and deeper depressions on the venter.

Maxtelliceras donerkanum (Bilyle and Coquand).

Ammunites demeykumms Bayle and coquand. Fosm. sécondaires rece dans le Chili, etc. p. 10. pl. : 2, tigns. $\ddot{-}-5$.

Retains the tuberculate stage until quite large, and in the full-grown shell, which is of great size, the last volution being 80 and 90 mm. in dimeter in one specimen, there are still six lines of well-developed tubercles and the subqualrate form of the rolution is but little modified This is by far the most primitive form of this group.

\section{METOICOCERATIDA Hyatt.}

This family is necessarily instituted for a peculiar group of species whose development loes not admit them within the pale of either Heinzidx or Pulchellidx, but whose later stages show that they belong in the sane group with the latter. The fimily and generic and to some extent specific characters are necessarily mingled in the following descriptions: 


\section{METOICOCERAS ${ }^{a}$ n. gen. Hratt.}

The roung, although distinct from those of IIeinzia, enable us to commert Ifeinzid and its more modified allies with what I have mismaned in Zittel's T'ext-bonk the P'edioceratidse, here corrected to Mantelliceratidae.

The type species, if the full-grom shells were the sole evirlence, would necessarily fall into the same genus with Heinzin muture on aceount of the resemhlance of the compressed later stages. But the following description of the rome slrows this to be a case of morphic equivalence based on entirely distinct modes of development.

The earliest stage observed has a coronate form with large lateral tuhercles. This stage is of short duration and appears on what seemed to be still the nepionic stage at ahout 2 to $2.5 \mathrm{~mm}$. in dianeter. The renter at this time is broadly romded and withont costa on the east. Subsennently at diameter of about $3 \mathrm{~mm}$. the ventral rows of tubereles begin to appear upon fine costa that pass across the renter and connect the rows of tubercles, and the costre also begin to spread inward on the sides. The terminatinns of these at $4 \mathrm{~mm}$. dianeter were withont tubercles. The costre are partially hifureated at the outer low of ventro-lateral nodes, but only one of each pair passes acoss the renter. The two rows of rentral tubercles are bone upon this costation, and in font of early one is a depression or transverse furrow exactly like those that are so peculiar and characteristic of Chelonicures royerimum. Internediate costa bewin to appen a little later and at first are without tubereles and are single. In this stage there is an eviflent modification of a late neanic substage of Cholonicoras, which has similar costa but a more coronate form. These custa subsequenty form a branch of the dichotomous lateral tostations or may remain single and short. Though the resemblance to Aspirloceras is apparent, the general form and aspect at this age can be accounted for as a parallelism with Psenelespidoreres of lurtia, which is one of the same stock, and arises as the result of the assmmption of the subquadrate form after the coronate stage in related organisms. It is of conse very likely that this Aspirleceran aspeet may have some genetic significance, but the comections that would pove this are not as yet clearly made out. One can not acrept all of the charateristies that appear in larral forms as of unquestionable genetic significance. They are safe guides only when carefully compared and 
systematically handlen with due regard to the collateral evidences, deducible from the later stages of development and the obvions relations of the adult and even senile stages. Thus in the present a ase, while the yommg would place this genus entirely outside the pale of the Heinziida, the later neanic and the ephebic stages and old ace and sutures show them to belong near that group. The peruliar elougated crestlike tubercles, the costre, and finally the sutures are of the Pulchellian type. When these later stages are allower their full weight, it is then seen that the development shows Metoicoceras to be the descendant ut some common form from which Carsteniu tuberenlate and Heinziu morimeialis are also descended. It is also apparent that this must have been either similar to or identical witl sone species of the coronate genus described here as Cheloniceras. The coronate young of Metoicoceres ane nut reconcilable with the young of Meinzia nor any other form of this timily, so fin as known. 'The development of Heinzin differs in the suppression of the comnate stage and of the sextuberenlate stage and the appeannee of the appoxinated lines of tuberrles on the venter of the Heinzian type by a tach ganic node of derelopment common in this group. The difficulty of reconciling the development lies in the finct that the miter mow of tubereles appear later than the ventrals and are not developed, like those of Metoicocems, from a primitive row preceding the ventrals in development. This nay he a case of what Cope las called retardation of development, but if this is so, the effect is really to accelerate the appearance of the Heinzian clanacteristics of the venter.

'The sutures of the entire gromps of Cheloniceratida and Mantelliceratidat are of the sane type. 'The nmmber of lobes and saddles is much nore limited than in Heinzinde on Pnlchelliidx, both on the dorsum and externally. The outlines also are excessively complex, with a certain Jagged look due to their long, subdivided malroginals, and also apt to be asymmetrical on trifid rather than bifid. There is also a noticeable absence of simple entire saddles and lobes in the umbilical region. Comprarison of the sutmres of Hetnicoceres with those of Heinzin or Pulchellin shows at once resemblances that are quite close enough to place swallovi in the same group with Ileinzia, and the sutures of Mctoicoreres are especially close to those of Carstenia? tuberculate. The development, being ineconcilable with that of any form of Meinziidre or Pulchelliidae, shows that the genus can not be placed in either of these families without confusing the picture of their systematic and genetic relations, so far as now known. 
Metoicoceras swallovi (Shmmard).

Pl. Xl, figs. 7-2t: Pl. XIII, figs. 1, 2: Pl. XY, figs. 1-t.

Ammonites smolloci Shumard, 1559. Trans. St. Louis Acad. Sci.. Vol. 1. p. 591.

So far as I lave been able to see, this species has not been previonsly figured, but that described below as whitei has been the one selected as the typical form of swallovi.

The following quotation from Shumard's deseription shows that while he had in hand perhaps both of the species here described his remarks scem to apply more decidedly to the one selected as sucullori mather than to its less prominently nodose and more complex companion. Shumard states "dorsmm [renter] flattened, transversely ribbed, nodose-bicarinate: * * * umbilicus decp, exhibiting about one-thind of each of the inner volutions and about as wide as one-half of the width of the last volution." If he had in hand such a specimen as the one le mentions as being 6 inches in diameter, and it was a representative of whitei, this large umbilicus would be just about in this proportion, hut it would be inapplicable to an ephebic stage as a young specimen of this species. If he had had a specimen of $H$. sucullovi, the large umbiliens would have been found in the neanic and ephebic stages in about this proportion. Shumar's other remarks apply also about equally well to either species, but the sutures, as described by him, point ont quite clearly the trpical form. "Iorsal saddle almost double the width of the smperior lateral lobe and divided into two unequal branches by a short subconical auxiliary lobe; the dorsal [outer] branch having three sinall notches, while the imner one is rounded and has usually only a single small notch at its internal border." Such simple ontlines as these occur only in the forms here referred to as swallovi, and one of the specimens (Pl. XIII, fig. 2) came from Grayson Comnty, Tex., the typical locality quoted by Shmmard.

The young figured (Pl. XI, figs. 7-15) and the sutures (PI. XI, figs. 18-23) were taken from a specimen fond in a piece of the matrix cracked off from the specinen shown in fig. 16 and are quite likely the young of this species, but it is probable that at this age the differences are slight between this species and whitei. Three specimens were obtained from this piece of matrix. 'That to which figs. 12, 13 belonged reached an older' 
stage than figs. 14, 15, and the last node near the umbilicus on this was considerably larger than the preceding norles, indicating that this young one belonged to this species. The breadth of side at this age was about $9 \mathrm{~mm}$., the transverse diameter about $6 \mathrm{~mm}$. 'The breadth of the side at the base of the living chamber, which was badly crushed farther on, in fig. 16 is $20 \mathrm{~mm}$., while the diameter between the tubercles is $16 \mathrm{~mm}$. The young volution was quadrate in form, the sides parallel, whereas in the specimen represented by fig. 16 , as may he seen in fig. 17 , the lateral zones are highly inclined and the venter much namower than in the young. In the fossil shown on Pl. XII, fig. 2, the brearlth of the side at the third suture is about $33 \mathrm{~mm}$, the transverse diameter between the costa being $23 \mathrm{~mm}$. The ontward inclination of the sides in this specimen was not so great as in the fossil represented by Pl. XI, figs. 16, 17, even at the same stage, and the nodes near the umbilicus were apparently not quite so prominent. Besides the markerl prominence of the nodes and their dichotomous costar, the living chamber in the young (figs. 14, 15) is elemly nearly threefourths of a volution in length, while in the later stage it appears to be in part complete and to be one-half of a volution in length. It is obvious that this species becomes more compressed with increasing age, and has a much narrower venter and less transverse diameter in proportion to the rentrodorsal than in the young. The protoconch has an arcuate venter (Pl. XI, figs. 7-10) and rounded dorsum, witl subangular bend as the outline approaches the opening of the conch. This opening, doubtless once the aperture of the protoconch, is much depressed or broal transversely and continues to have this form throughont the ananepionic and metanepionic substages. The elevation of the renter begins in the second volution, fig. 10, but the form remains smooth and the sutures goniatitic until about the fourth volution. ${ }^{a}$ 'Then nodes begin to appear on the ventrolateral angles and the venter becomes brouler in consequence. 'The venter' is smooth at this substage, the first of the neanic substages. In the next substage, about one-half of a rolution later, fig. 14, the costa become more prominent near the umbilici and wrinkles appear on the venter, each accompanied by a pair of tubercles. In the next substage, which was not seen, it is probable that these rentral costre become comnected with the lateral ones and equal in number to them, and nodes appear on the immer 
endis of the linteral costre and there fuse into more or less dichotomous form. Th. This fusion is not as complete in the fossil shown in fig. 16 as it is in the one slown in Pl. XIII, fig. 2, at a later age.

The sutures seem to follow about the same steps in progress of develnpment as the external "haracters. Fig. 11 gives an enlarged sketch of "aecmm, which seems small in this sperimen and which opens into a large siphuncle, whose parts condd not be studied any further than is risible in the drawing. Although every effort was made, and this specimen was remarkably clear and transparent, nothing definite conld be made ont beyond the ceecum. It is certain that the dark color of the wall of this borly has no posterior prolongation or frosiphonal continuation. The second septum, begiming the sutures af the metanepionic substage, had muquestionably a divided ventral lobe, as given in fig. 10. This was established by many repeated abservations. There were, as wsual, but two Inond goniatitic saddles of the Tonnoceran type on either side and one hroad lateral lobe on each side, with a distinct saddle at the line of involutim. I was not able to detect any depression, such as I have previonsly lescribed in other forms as an embryonal umbilicus, occurring at the beginning of the true comch. In the paranepionic substage the suture becomes distinctly divided on the sides intu two broad saddles, with a lateral lobe and a lobe at the line of involution on either side, and during this substage the dorsal suture assumes finally the anpect given in fig. 21 . The sutures (fig.s. 18-20, 22) belong to the neani stage, represented in figs. 12-15. T'hey show the usual mode of division common in Ammonoids of the Jura and Cretaceous, the incoming of anxiliary inflections on the primitive second lateral saddle and the primary bifid division of the first lateral saddle and first lateral lobe, the entire aspect of the siphonal saddle and its subseruent bifidity. Fig. 22 of $\mathrm{Pl}$. XI shows the peculiar prolecanitean anpect of the dorsal inflections before the end of the neanic stage, and illustrates my previous statements with regard to the retention of ancestral wharacters by these internal sutures. Fig. 23 of Pl. XI and tig. 1 of Pl. XIIl are of very nearly the same age, and give the beginning of the epliebic wubstages. The latter show that the primitive median marginal lobe of the prinitive dorsal saddle becomes the large marginal dividing the full-grown first lateral saddles. This suture also shows that the second lateral saddle has a trifid termination in some specimens of this species. 
The sutures in the two specimens here described as swallovi are sumewhat abraded, but their details of ouline are sufficiently well preserved in different sutures to enable one to see how much simpler they are than in M. Whitei. This simplicity of the marginals is not so great in some specimens as it is in tig. 2 of Pl. XIII, since in the suture (Pl. XIII, fig. 1) the second lateral is trifid and in fig. 13 the fourth lateral saddle is bifid. The number of inflections on the sides appen's to he less in this species than in uhitei, five only being present on both sides, with saddles at the lines of involution: and in the fossil shown in Pl XI, fig. 16, there is the same number. with a lobe at the line of involution.

Locality: Grayson County, Tex.; Utah.

Age: Colonido epoch.

\section{Metoicneeras fimbosum n. Ap. Hyatt.}

Pl. XY. fig. 5-s.

The single forsil upon which this species is founded could wot be plared in any of the species here deseribed under the same genus. It has stonter, broader volutions than any of these, and, instead of becoming more compressed as it grows older, continnes the same rate of increase in the transwerse diameters The involution is abont the same as in M. suellori, but there are no nowes on the muljilical shoulders at any stage, although the alternating longer costie reach to the umbilical shonders. Their greatest prominence is at a short distance rentral of the nmbilical shoulder. The costations are like those of the oldest stage of whitei, i. e., regularly long, prominent costic altemating with short ones. The two outer lines of tubereles do not liffer from these of other species. The sutures are internediate between the simpler character of those of $M$. sucullow and the more complex onthes of those of $M$. white The first lateral saddles and lobes lave about the sane general aspect as those of $Y$ whitei, but the anxilinies are similar to those of .M. sevellovi, exrept that the second lateral saddle shows small marginals and a tendency to division on its outer side, which has not been observed elsewhere. The third lateral saddle shows in some sutures of the left side a tendency to become divided, which is necessarily exaggerated in the drawing and which is entirely absent in many sutures, 
both younger and older than the one drawn. The dorsal sutures conlu be seen only from above and in a fragment of the cast of the last camera, which is not included in the figures given. It was evident that the antisiphonal lobes resembled those of M. swalloni and Heinzin in being elongated and considerably telescoped into each other. The saddles also were similar, especially the first dorsals, which were namow, long, phylliform, and deeply eut into by the marginals, as in Heinzin matum. There was also a similar broad pair of second lateral dorsal saddles; these certainly had one marginal lobe and perhaps two, being perhaps trifid, but rely flat on their bases. The remaining saddles were entire. There were apparently five saddles and four lobes on the right sitle and six saddles and five lobes on the left side, eorresponding to the differences in number of the extemal anxiliaries on the same sides. The overlapping of the sutures is noticeable in this specimen, but whether it can be considered characteristic of the species is doubtful. The whole diancter is $85 \mathrm{~mm}$. The last volution on the face of the septnm from the center of the venter to the line of involution is $50 \mathrm{~mm}$; the ventro-dorsal diameter is $35 \mathrm{~mm}$. The amount of involution at this point is two-thirds of the breadth of the side of the next inner volution, being 17 to $27 \mathrm{~mm}$. The umbilicus, in consequence of the smoothmess of nmbilical zones and the nonextension of the costie internally, has a smooth, funnel-like aspect, entirely listinet fiom that of $M$. sucallovi, although it is nearly of the same size and differs therefore from that of whitei in being much larger as well as smoother.

Loculity: Texas.

Aye: Colorado epoch.

Metolcoceras whitei $11 . \mathrm{sp}$. Hyatt.

Pl, XIII, figs. :3-5: Pl. XIV, figs 1-10, 15.

Buchireras smallow; White, 1875. Geog. and Geol. Expl. and Surr. West of 100th Meridian. Vol. IV. p. 202, pl. 20, figs. 1 a-c.

Buchiceprss sucallomi Stanton, 1594, Bull. U. S. Geol. Survey No. 106. p. 16s, pl. 37; pl. 3s, figs. 1-3.

The external characteristics of this speeies, in comparison with $M$. swallovi, consist in more compressed volutions without such prominent nodes on the mubilical shoulders. They have nodes, but these are more a part of the costre and less prominent, the sides are consequently flatter than in suallovi. There is a deeided tenteney in the Texas specimens to 
have the umbilicus smaller and the inner row of the two outer lines of tubercles elongated longitudinally and parallel with the outer rows. The sutures are more eomplex at an earlier stage and remain more complex throughont life as regards their marginal digitations. The first lateral lobes are also narower and longer in proportion in the later stages than in sucllori, and the inflections are more numerous at the same age, being from six to sevent, instead of five or six as in secellori. The youngest stage seen (Pl. XIT, figs 1,2) had a living chamber complete near the umbilieus and not quite three-fourth of a rolution in length. Several specimens, shower a completed living chamber near the umbilical shoulders and on the sides, and in adnlts it is much shorter, invariably one-laalf of a volution in length. The sides were smooth and flat at the begimning of the onter volution in this specimen. The coste alpeared as shown in the figure and nodal termini were developed on the last costation near the apertnre. These were also present in the specimen shown in fig. 4 , but, as may be seen in figr. 2 and 5 , these were not prominent as in sucllori. The same is true of all of the seventeen specimens examined besides Pl. XIII, fig. 4 The elongated second row of lateral tubereles found in fig. 4 is also perceptible to some slight extent in the specimen fig. 7, but is absent in younger stages and is not present at any stage in some specimens. This second row of tubereles may be very slightly developed in some specimens, and the costre are also much less prononnced and the venters namower than in those figured. The other two specimens show a much stouter form with broader venters and une prominent coste. These can only be separated from true swallovi by their costae, flatter sides, and less prominent umbilical nodes.

An old suture of this species is shown on Pl. Xlll, fig. 5. This was the basal suture of a fragment of the living chamber of a fossil of about the same size, probably, and age as the one shown on Pl. XIll, fig. 4. The differences of this suture appear to be considerable when compared with Pl. XIV, fig. 8. The extemal characters of this fossil are equally decided, but the absence of the internal volutions and the variability of the sutures in this species does not justify the separation of this as distinct from whitei. The latter part of this living chamber and the whole of another larger fragment has huge fold-like costa that cross the venter, cutting it into waves. The costre are flat on the venter with abrupt forward edges. 'The ventro-lateral 
tubercles and the second lateral row disappear on these rostax. The decreane of the involution thromgh shrinkage of the later diameters is greater in this than in the old age of the specinen shown on Pl. XIII, fig. 4. lipeadth of the side firom line of involution to the siphomal sardle at the suture figured is $65 \mathrm{~nm}$. 'The length of the living rhamber on the outsiche or venter is $190 \mathrm{~mm}$. and apparenty complete, and the breath 75 mom. In the specinen shown in Pl. XIT, fig. 7, the nomal late of increase is from 50 to $70 \mathrm{~mm}$. in the same distance measmed along the renter, and in the living chamber of the fossil shown an P'I. XIII, fig. 4, which is of the sane length on the venter it is from 70 at the base to $80 \mathrm{~mm}$. near the rnd. In both of these old specinens the length of the living rhamber and decrease in the rate of growth was thelefore about the sane and about one-latf of what it was in the fossil shown on Pl XIT, fig. 7, whiche was alsu an old specimen but was neasured along the septate and therefore younger portion of the outer volution. The increase by growtl previous to this must hare been greater still. The bromdening of the renter noticeable near the aperture (figs. 3 and 4), the sprearling of the costre acouss the venter, amb the loss of norles are the same in. all three of these specimens and show then to have entered npon the last or paragerontic substage ur decline. The youngest suture examined in this species is shown in Pl. XIT, fig. 3, from the left side, and this has fully entered the ephebic stage and is alleady nome complex than those of surallori at a much later age. The corresponding suture on right side of the sane specimen is similar, but the third lateral saddle was quallitid instead of bifid and the fourtle lateral was more distinctly bifid and ploylliform. The matrix of this fossil from Elm Fork, Tex. was a gray limestone, whereas that of the sperimen shown (fig. !) was a red clayey limestone, but from the same loculity. The suture was much older, but nevertheless had simpler third and fomply saddles on both sides of the muter volution. The position of the suture of the specimen shom in fig. 7 , given in fig. 8 , is indicated in fig. 7 hr a straight line near the renter, but the sutures throughout this solution have the same outlines. This and tig. 10 are the most complex of the full-grown sutures observed in this species.

Fig. 10 was taken from the left side of Pl. XIII, fig. 4, and slows the ontlines of about the same age as in Pl. XIII, fig. 8. The shell was stripperl form a part of the fossil shown in Pl. XIII, fig. 4, also, and the corresponding suture on that side also observed. In this way it was found 
that the sutures on the two sides differed considerably. They were alike in their first and second lateral lobes and saddles, but the third lateral saddles were simpler on the right side, the side given in Pl. XIII, fig. 4, in having the marginals lesis distiuct and the fom th latemal was entire instead of being bificl. The ontlines intermally were the same and there were seren saddles and seren bobes un cacl side, and saddles at the lines of involution. The differences between the more fully developed sutures on the left side, those of the right, and the oldest suture showed similar degenerations, the saddles becoming much shorter and broader in proportion and the narginals less distinct.

The table on page 126 gives an aceount of the rariations observed in the sutures. It will be observed that the first lateral lobe is quite generally bifid, but in the largest specimen (Pl. XIT, fig. 8) from Eln Fork, Tex, it is sometimes trifid. It is rery obvious that this characteristic may he capable of two translations, some of the first lateral lobes in this specinen being made trifid hy a slight enlargement and extension of the main terminal marginal lobe.

The second lateral lobe raries from simple primitive form of bitidity to trifid whthout regard to age, but in most specinens it is bifid. The third lateral saddle is bifid or trifid without regard to age, but tends to become quadrific in older stages. The fonth raries from entire to bifid or trifid, but in most cases is bifid or trifid. 'The fifth ralles from entire to bifid or' trifid, but is in most cases entire, sometimes bifid but rarely trifid. The number of lobes and saddles on the sides varies from 11 to 14 in the early ephebie substages and from 13 to 16 in the full grown.

No. 6 is taken from a fossil with a notably stonter rolution, more prominent courser costre, and larger tubereles than any of its companions of the same size from the sime locality, lilm Fork, Tex The whole diameter of this fossil when complete was probably not less than $63 \mathrm{~mm}$. and the living chamber of the usual length, a little over half of a volution. Lnluckily, like all other's of this species, the aprerture las been badly broken and the rostrum could nut be olselved. I at first thought this exceptionally stont and more coarsely ornamented specinen must be a different speeies, but the sutures, when laid bare, were identical with others here described as $M$. whitei, especially close to that given on Pl XIV, fig. 10. 
Thriations absereed in sutures uf Metricoceres whitci.

The number of saddles and lobes represents one side only. All except Xos. 11, 12, and 15 are from Elm Fork, Hortons mill, Dallas Connty, Tex.; No. 15 i. from [tah; no locality is given for Nos. 11 and 12.]

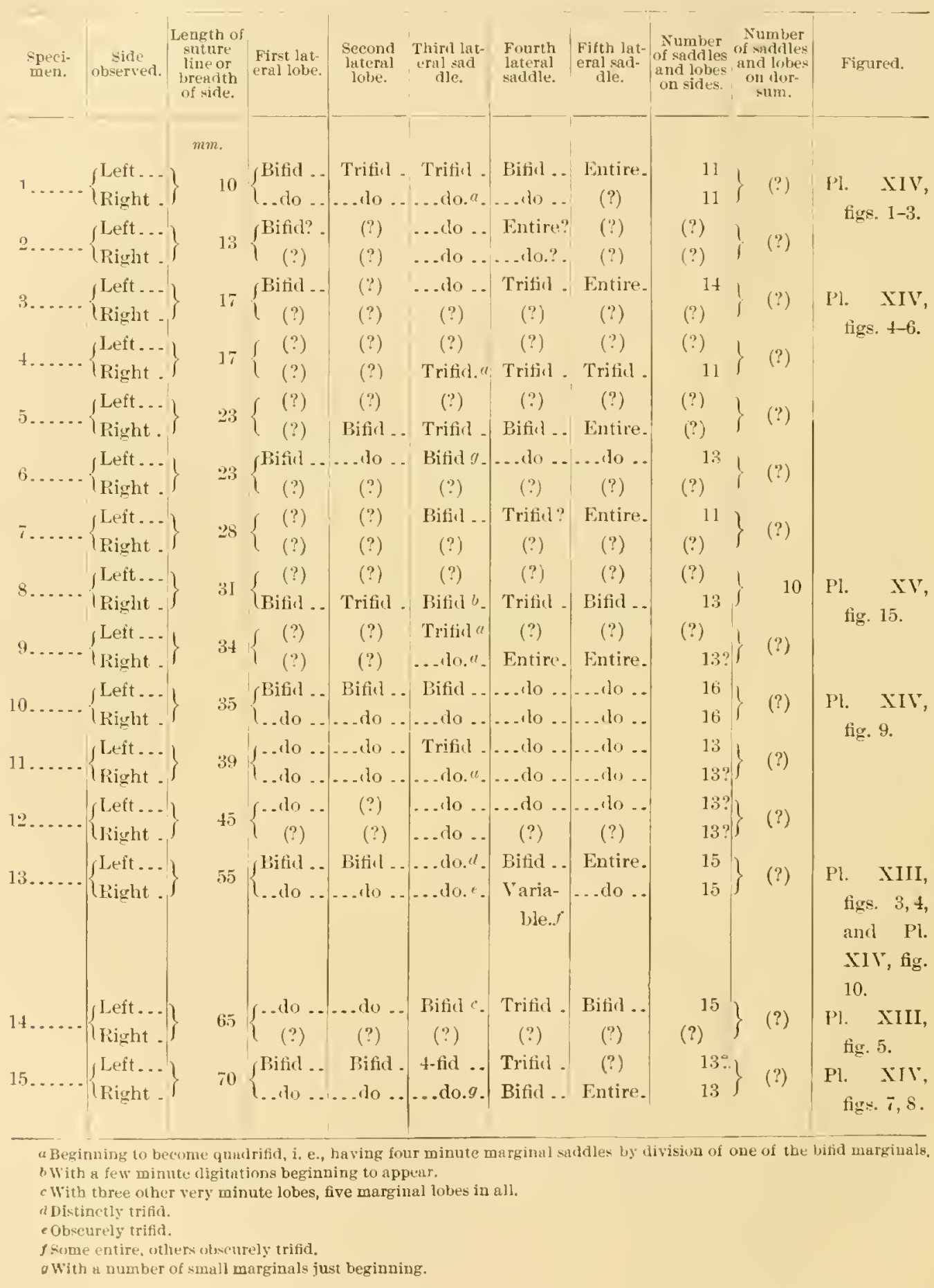


In all of these specimens the first lateral saddles were of very nearly the same general character, decidedly deeply bificl, cven in the youngest stages recorded, and with both arms subdivided by one or nore marginal lobes; the second lateral saddles were also complex at all stages observed, and one small specimen not recorded in the table, with suture lines on the last volution rumning from 12 to $18 \mathrm{~mm}$., showed the same facts. "This has bifid first and trifid second lateral lobes, with quadrifid third lateral saddles on both sides. A bifid fourth is visible on the right side when the rolntion is less than $12 \mathrm{~mm}$. This same saddle with a bifid base is the only one visible in another fossil with a suture line of abont $8 \mathrm{~mm}$. It is evident that the law of valiation in the sutures is that lobes and saddles increase in rariability of ontlines and in number progressively from the venter toward the dorsal lines of involution, the so-called anxiliaries or derivatives of the primitive second lateral saddles of the young being far more variable than the first lateral saddle.

Loculity: Kanab Valley, Utah; Elm Fork, Dallas County, Tex.

Age: Colonado epoch.

Metolcoceras acceleratum 11. sp. Hyatt.

PI. XIV, tigs. 11-1t.

I at first thought this to be the young of the species describer by Whiteaves as I'lacenticeras liardense, but the figures given by him merely indicate that the venter had continuous costa across it. The condition of his fossils was, however, such that he lid not see the venter, and this can only be infered from the lateral aspect as given in his drawings. Apparently there were no tubercles on the sides in the full-grown specimen, and the umbilicus was about the size of that of $M$. white $i$ and not so small as in this species. There were no nodes nor prominent costre near the umbilical shoulder in this fossil, and the two outer rows of tubercles were much less prominent than in the preceding species. The venter in the first half of the outer volution resembled that of $M$. white at an earlier age on the first quarter of the onter volution of the specimen shown in Pl. XIV, fig. 1, but with less decided tubercles, and on the latter half of this volution it is changed as the venter is in the old age of $M$. whitei. That is to say, the costre that cross it are prominent and flat, but not channeled nor concave. The costre on the sirles are not so prominent and coarse as in 
whitei. There are more of them, and omly the last begin to reach entirely arruss the sides. There is a sigmoidal chamel on either side that does not reach across the renter. This is a elanacteristic ocemring also in \%. Tiumleuse, but not in other species. This occurs close to what must have been the edge of the aperture, since the living chamber is considerably over tluee-fourths of a rolution in lengtl and was probably a little longer when complete. The black line slows the position of the basal septum of the living chamber shown on the opposite side of the fossil figured.

Locality: Ehm Fork, Horton's mill, I)alkas County, Tex.

Age: Colorado epocl.

\section{HEINZIID $A$.}

The members of this family are easily distinguishable from the typical Pulchelliidax by the possession at some stage of elongated, ismally double, but more or less comnected tuberenlar terminations on the ventral ends of the lateral coste. All of the forms so far known have coarser and more complete lateral costre than are nsual in Pulchellidide, and there is, expecially in primitive forms, a tendeney to the development of stouter rolutions, with less involution and conserquently wider umbilici. The a verage size is larger, and the development is very distinct in all forms, so fill as known. 'The young are stouter, less involute, and have costa continuous across the venter: The tubercles appear upon these costre in two lines of single tubercles, and then subsequently two rows are developed "upon the outer sides of these that remain more or less closely comnected. The lateral costex are similar to those of Pulchellidix, but sometimes a median or an imner row of tubercles or both appear in the later stages. The rentral chamels are apt to be real channels furrowing both the enste and the intercostal spaces on the renter, and in the young and in primitive forms are apt to be limrow and smooth. The sutures are similar to those of l'ulchelliidar, but as a rule lave fewer and larger saddles and lobes, and the outlines more complex at the same comparative age, judging from the size of the casts.

The development is sudistinct from that of Pulchellida in some species of Meinzin that if it were not for the fortunate arecident that placed one specimen of Heinzin matwa in my way, I eould not have offered any rational suggestion as to the true relations of this family. The de relopment of Heinzin matura, however, shows, as stated below, a form that in the 
young is involute, smooth, and compressed witl a rounded renter as in the young of Pulchellidae. 'Then it las a faint line of ventral tubercles and flat rentel followed by a true Pulchellian stage with channeled venter bordered by single tubercles. In other words, at this age the species is like Pulchellia except that the tubercles are not elongated crests. The ephebic stage shows the usual terminal double row of tubercles of the Heinziidae. The conclusion from this evidence is that the Pulchellidae probably arose from Heinziu or some rery similar form through the increase of compression and involution and from the prolongation of the smooth larval stages, the suppression of the preliminary lines of ventral tubercles in the young and the tendency in later stages to suppress the second lateral lines of tubercles. This inference acquires some support also from the fact of the earlier appearance of Heinziidre in the Neocomian. We can in this way account for the communal resemblances of these two families in their adult forms, costre and sutures, but it must be borne in mind that the evidence upon which this inference is based is not by any means complete.

The evidence with regard to the commection and genesis of forms is less complete than in the Pulchellidx, hut the following diagram gives the apparent relations of the genera so far as the ontogeny at present known indicates these:

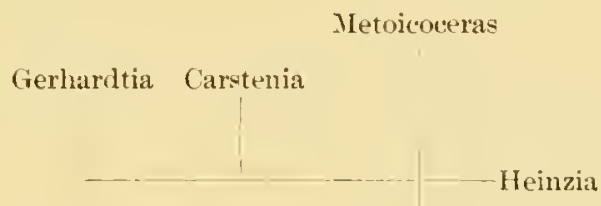

Cheloniceras

HEINZIA Sayll.

Sayna defines this genus in the following terms: "Les espèces qui se rattachent aux Pulchellia subcaicedi et movincialis sont nettenent caractélisées par une ornementation vigourense, visible dès les tour's embryomaires, un accroissement en général moins rapide, les sutures le plus souvent très éloignées les unes des autres et remarquables par le grand développement en largeur des selles et l'amoindrissement des lobes très étroits et peu découpés." The group describer by Sayn under this name is obriously a

a Amm. Iu Barrémien du Djebel-Ouach près Constantine: Amn. Soc. d'Agriculture de Lyon, bth series, Vol. Ill, 1890, I'. 151.

MON XLIV-0:3-9 
composite of several general distinct in their development and in their sutures from any form of true Pulchelliirle and also differing decidedly from each other. The species liere mentioned as $I I$. sayni is assumed to be the type because it is one of the first two species mentioned by this author and is the first one of these figured. His Pruchellic subcricedi appears to tue to belong with Pulchellia criccrli (Karsten) in the genus Carstenia.

\section{HeInzta sayni Hyatt.}

P'tlchellia prominciulis Sarn, 1890, Ann. Soce d'Agriculture de Lyon, 6th series, Vol. III. pp. 165, 166; pl. 1, fig. 16; pl. 2, fig. 7.

This is neither the species figured by d'Orbigny nor that given by Nicklès, but a dwarfed, compressed form with fine tubercles and fine costre developed at a comparatively early stage. It is similar to true $H$. provinciulis in being less involute than corioli.

Locality: 1)jehel-Onach, North Africa.

Age: Barrenien.

\section{HeINZIA CORIOLI Nicklès.}

I'ulchllia (Heinaia) curioli Nicklès, 1s:0, Mém. Soc. géol. France, Paléontologie, No. 4, p. 53, pls. $6, \%$.

This species and another, supposed to be allied to saymi, are both larerer, have coarser ormaments and more complex sutures than the Africun forms, and broad chammels like cierharltia.

Loculity: Spain.

Alye: Barremian.

\section{Heinzia heinzi Coquand ${ }^{a}$}

Pulchllia heinai Sarn, 1s90, Ann. Soe. d'Agriculture do Lyon, 6th series, Vol. III. 1). 2, tig. 5.

'This species has similar munuentation, but much coarser than in H. summi. The sutures are given, and these are not similar to those of Pulchellidae.

Locality: North Africa.

Age: Barremian.

"Coronites is represented in North Africa by a small group of dwarfed forms having the development and general aspect of the morediscoidal forms of Hoplifes. The type is for. (Heinzia) coronatoides (Sayn). This forn has a ventral channel, heginning at a comparatively ealy stage while the young are still highly coronate and the coste dichotomons on the venter. These spring from singie nodes $\mathrm{cn}$ the latero-ientral angles, which are coincilent with the umbilical shoulder. These subequently 
Heinzia hispanica n. sp. Hyatt.

Pulchellin (Mtinzir) ef. provinciulis Nicklès, Mém. Soc. géol. France, Paléontologie, No. t. pls. i. 7.

Nicklès's figures give a species with smaller unbilicus and a shallower, wider channel furrowing the costa unly, as in Pulchellia. The costa have more prominent nodes and are nore prominent on the renter, which is crossed by them and cut nu into waves as in Pulchellia.

There is one specimen in the Insenm of Comparative Zoology, probably from Escragnolles, that I have labeled Heimzia aff. hispanica. It differs from this species only in having more involute whorls and perlaps somewhat cuarser costa and possibly the sutures a little more complex.

Heinzia pulchellforisis 11. sp. Hyatt.

This species, from the enllection in the Musenm of Comparative Zoology, has exactly the form and aspect of some of the typical species of P'ulchelliu, except that the costa are more prominent and cross the inner parts of the sides, and the onter row of tubercles has the broad, double character of those of the Heinzia group. This has no inner line of tubereles and has been consintered similar to didcyanus, which is a species of Vichlesin.

Locality: Escragmolles, France.

Age: Barrénilin.

\section{Heinzia provincialis (d'Orbigny).}

P']. XV. tigk. 19, 20; Pl. XVI, figk. 1-3.

Ammonites promincinlis d'Orbigny, 1850 . Prodrome de Paléontologie, Vol. II, p. 99. I'ulcrellia procinciulis Uhlig, 18s:3, Denksch. K. Akad. Wiss, Wien, Vol. XLVI, pl. 20, fig. 2 .

Assuming Uhlig's figure to be taken from a species identical with d'Orbigny's, the specimen here figured is a true representation of this

extend internally into lateral single coste and the nodes disalyear. The rost: become single on the sicles on may remain dichotomous. The result is a form in some species that is alnost an exatt parallel with some forms of the llor liticle. The sutures are simple and have an immature aspect. The rentral is rather narrow and is divided by a small truncaterl siphonal saldle. The first lateral saddles are very broad, hifid on one sirle in $I I$. hoplitiform is and trifid and still broarler on the otlier. The first lateral lobesare narrow anel trifid or biticl. The second lateral saddles belong to the auxiliary series, and are much smaller than the first aml only slightly dentated, while the thirl and fourth caddles are entire. The second lateral lobe is very short and entirt, and two other similar smaller lobes complete the literal line.

This description is taken from Sayn's figures. 
species. It has the narow, deep, smooth rentral channel, which is also slown in Uhlig's figure, with the same peculiar abrupt ventral terminations to the costre with forward hend on the edge of the channel. The venter is not cut up intu waves by the crossing of the coste as in $H$. mlrhelliformis. The ohmel, in fact, is deeper than the depressions between the custer, and the ridges that guad it on either ridge give a pointed aspect to the forwarl terminations of the costre. This is also observable in Chlig's figure.

On splitting this specinen I succeeder in exposing three substages of neanic ige. The first substage showed faint costre that crossed the rounded venter, the form being at this time rounded, with gibbous sides and open unbilins. Then faint tubercles appeared, the venter still remaning rounded betwean them. Thesc tuhercles in the next substage became more prominent, and the venter between them became flattened. The costre becane more prominent at the same time on the onter half of the side and made a slight forward bend on to the venter. Foon after this a rery faint, narrow, linear depression indicated the beginning of the rentral chammel. I was not able to discover at what age the stcond range of tubercles began to come in $1001^{2}$ their exact position. The volution is gibbous on the sides throughout these early stages and is a rather stont young form with an open umbilicus.

Loculity: Escragnolles, France.

Aye: Barremian.

ILEINZ1A MATLRA 11. s]. Hyatt.

Pl. XV. figs. 12-1s.

This species is allied to that described above by Sayn. It is similar in its compressed form, in the amonnt of involution and in the broad ventral channel, and in having a row of tubereles on the umbilical shoulders. 'The coste are, however, much broader' and have the louble extermal temination of the gromp of Heinzia. This termination is, howerer, not distinguishable on the earliest part of the outer volution, but is well cleveloperl on the third yuarter' of this rolution. 'This termination is seen in this specinen to be a modification of the ends of the costae, and it is mot due to the alppoximation and coaleseence of an inner wow of tubereles with the outer row. 'The shell is preserved on me sime of this specinen and shows 
the same markings as on the cast. The yomng is much flatter and increases faster in the abdomino-r lowsal diancetes than in other species of Ifeinzid and remains smontl mutil a later" age. The tubercles appear also later on the venter, and there is a that vental zome for a more prolonger stage than in 11. monincialis, and the ventral chamel alpears later. 'The umbilical tubercles aypear on the last rolution figured and are at first single. Then they probahly beome [domble] hy the development of two other dows of tubercles near the ventral lines, but this was not actually seen on the specimen.

Locality: Escragnolles, France.

Ayr: Balreminian.

Heiszia ovachensis (Coquand).

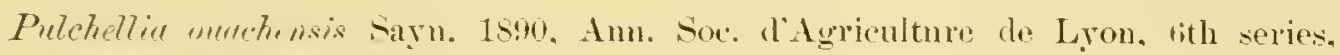
Vol. III. 1'. 15i. pl. 1, fig. 15 (not fig. 14).

This species, describer as a Pulchellin by Sarn, is an involute compressed form probably in the same genetic group with $H$. maturu. 'This is show by the rentral clumel and costex and tubereles on the umbilical sloulders. It has not the broad domble terminations of the coste ubserver in 11 . mature. Fig. 15 is probably a true P'nlekellia, and is cited under that generic name as $P$. liliuni.

Locality: Djebel-Ouach, Nortlı Afica.

Aye: Bamrenian.

CAR'TENIA n. gen. Hyatt.

'This remarkable group has, as shown by Karsten's figure of Carstenia lindigi in the latest neanic or early ephebic stage, coarse costre with double terminations becoming dichotomous at the middle lateral line and having a line of norles at their junctions. "These are contimued later' on the singie costce when these appear. The arising of the double line of outer tubercles close together on the ventral line is also slown in this figure. The form is stout in the type nentioned above and similar to that of Heinzic provincialis, but in the Carstenia (Amm.) caicedi Karsten it is more involute and compressed. The rentral furrow in C'arstenia lindigi in the young is narrow and similar to that of Heinzia, but later it broadens and becomes similar to 
that of Gerhardtin. 'This oceurs in an earlier age in Carstenia caicedi. Descriptions are wholly taken from Karsten's figures. ${ }^{a}$

\section{Carstenla subcaicfid (Kairsteli).}

C. subcricedi (Karsten) is described by that anthor as having heary coarse coste bifureating like those of cuicerli and, if his small figure represents the young or a primitive dwarfed form of this group, it shows how very distinet its development must be as compared with that of other genera.

Carstenia? tuberculata 11. sp. Hyatt.

C.? tubcrculatu (Pul. provincialis Gerhardt) ${ }^{b}$ is described by that author as identical witlı lindigi Karsten. It is, however, less involute, and, although having similar quadragonal volutions, has coste like those of Gerhardtia and there is no median lateral line of tubercles. The sutures are more like those of Metoicoceras than of Heinzin morinciulis. It is possible that the development of this species may show it to be more nearly related to Metoiroceras than to Carstenia. It has, however, the peculiar channeled bases of the second row of tubercles on either side that have been found so far only in this last-named genus. All of these have been supposed to be of Barremian age. Its eharacteristics seem also to ally it decidedly with such forms as Heinzia movincialis, and to indieate a common origin for all of these genera in some primitive form with similar but more tuberculose volutions. It is obviously a more primitive form than Heinzia, which has more compressed and often more involute shells and retains in its latest stage the form and aspect of the young of $H$. provincialis and of the earlier neanic stage of Metoicoceras surallori. The resemblances to Gerhurdtic are also close, as may be seen on Gerhardt's plates, and its form is similar to the young of Carstenia caicedi as figured by Karsten.

These affinities and its obviously primitive larval characteristics show it to be the nearest approach yet found of the probable genetic ancestor of the Heinziid:x.

"Génl. de l'anciemne Colomh. Tenez. Nour. Gren. et Ecualor. Bertin, 1566.

Kreidef. in Columbien: Neues Jahrbuch lür Min., Creol., und Pal., Beil.-Bd. NI, 1s97-9s, p. 15\%, pl. 2, tig. 8 . 


\section{Carstenia galeata (d'Orbigny).}

Ammonites gateatus d'Orhgny, 1stz, Vọage cims l'Amérique méridionale, Vol. III. pl. 17. figs. 3-5 (not figs. 6, 7).

Pulchellic caicedi Gerhardt, 1897. Nenss Jahrb. für Min., Geol., und Pal. Beil.-Bd. XI. p. 151. pl. 3. fig. 7 .

This species has a form, coste, ventral channel, and onter tubercles similar to those of $C$. caicedi Karsten, but having the single costar appearing later, the double outer line of tubercles disappearing at the same time, and no median lateral line of tubercles apparent in d'Orbigny's fignres. The donble ont 1 tubereles are observable in figures given by d'Orbigny at the beginning of the onter volntion and are quite plain upon an excellent cast of this fossil from Chile in De Koninck's collection in the Musem of Comparative Zoologr. Figs. 6 and 7 of d'Orbigny are true Pulchellia, not the young of this species. Pul. caicedi Gerhardt has exactly the form and aspect of the next younger parts of the rolution figured by d'Orbiguy and observable on the last mentioned.

\section{GERHARITIA n. gen. Hyatt.}

The near alliance of this genus with Heinzin becomes apparent upon comparison of the type Gerharltia yaleatoides (Kansten) with Heinzia movincialis (d'Orb.) and Heinzia? tuberculutu. The mbilical characters are similar so far as the amonnt of involution and the general aspect is concerned, but the umbilical shonlders are more prominent, the mubilical zone is sometimes eoncare, broader, and the nmbiliens deeper. The shell in the neanic and adult stage is more compressed and nore involute than it is in Ifeinziu at the same age and also nore involute than its own ephebic stage. The extreme decrease of involution in old specinens may also be noticed in these forms. The coste in the neanic stage ane much finer and more closely clowded than in any genus of this groul. The costre are similar, but the onter row of donble nodes are absent or only very faintly expressed. The sutures are more complex in ontline, but of the same general type.

'L'he for'm is more conpressed, the renter more contracted, and practically bounded by the elongated single nodal termini of the costre. The furrows between the costae cross the renter, cutting it up into flexures, and the ventral clammel is very broarl and affects the flexmes only, not descending to the level of the ventral furrows. 
liesinles the type mentioned albere, this group contains Ger galeatus (Kinsten) (rou Buch's figure of this species is too poor for comparison), and (rev. velezinsis 11. sp. Hyatt (Pul. Mirluyi Gerh., "). cit., pl. 3, fig. t). Amm. diduygmus d'Orb. belongs to genus Viclilesia. Amm. didayanus Karsten is fmobably a younger stige of the species figured by Gerharelt, and it came tirm the sime locality, Telez.

Similar species have been viter from other comutries by Gerhamlt, but these arr moknomin tor me.

All species me of Barremian age and found in Colombia or Chile.

The sutures lave been well tigured hy Gerhadt and are quite different tiom those of $C^{r}$. tuberenlate and $H$. morincialis.

\section{PULCHELLIID $A$.}

'This family has highly involute compressed shells. The costa, when these are present, ane acyuired at a comparatively late age, and the tubercles, when puesent, are single elongated crests on the ventro-lateral angles of the costix. The coste usually eross the venter even when there is a channel on their outer surfaces. The sunken intercostal fumows that cross the venter also are not as a rule affected by the chameling of the costa.

The sutures ale of the same type as in Heinzia, but with somewhat more complex ontlines. I lave had 110 opportunity to examine the dorsal sutures.

The primitive form is Psilopulchellia," which retains the smooth keelless condition of its own roung thoughout life. This stage is transient in the develument of other genera. In Vicklesia it is followed by a stage with a flat renter, and this is then followed by the development of lateral costax that cruss the venter without tubercles or chammels, or the latter may be develngerl direetly from the previous stage.

Sulpulchellici has similar stages followed by a chameled renter due to the development of two slight riclges.

I'ulchellia develops lateral costie that cross the renter, but these are concare on the venter and have lateral tubercular erests in place of the riliges of Submehellia. The intercostal furrows also cross the renter, but are usually convex on the venter between the costae. The tubercles have heen miversally but emonemsly spoken of as keels. They are really not The anthur falled to describe or dite any species belonging w 10:ilopulchellia.-T. W. S. 
continuous at any stage and can not even be accurately described as ridges. The tern canina or keel should be confined entirely to the continuous azyous ventral elevation. The tem bicarinate is confusing and might be especially tromblesome if occasion shoukl arise to describe a form laving a really double or split keel. A further moditication of the development takes place when a keel arises upon the smooth rounded venter of the earlier stages as in I'silotissotia. This form is apparently transitional to trute Tissoticla, but these affinities disappear upon comparing the ontogeny with that of 'Tissotiillae, and especially when the relations of these to the flat ventered and keuled and chameled forms of Psembtissotia are recognized. The sutures of P'silotissotic are also decidedly Pulchellian and there are also transitional forms connecting it with I'silopulchellia. Lopholobites, so far as known, appears to be adequately accomnted for as a retrogressive moditication of Psilotissotia or some of the smooth forms with which it agrees in external characters. This suggestion requires, of conrse, to be tested by the comparative study of its development and that of the similar forms of this family. The natural arangement of these genera upon the basis of their untogeny seems therefore to be as follows:

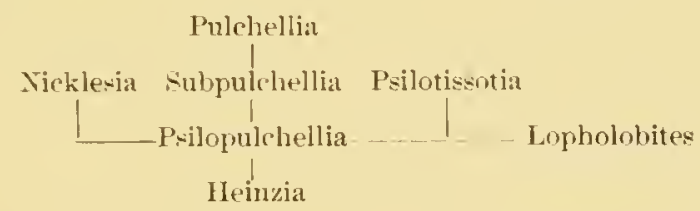

It seems obvious from the development of the young of most genera and the apparently full-grown Sulpulchelliu, and from the evidence of the sutures, that this group is closely related to Engonoceratida. If this be so, the latter can be explainerl as a retrogressive form evolved from Subulchellia as its most probable Neocomian ancestor. The supposed relations of some of the genera to Stoliczlaia are discussed under the head of Pulchellia. The parallelism between some of these forms of I'ulchellia and the Hoplitidae is so close that it requires the evidence of their younger stages for their separation. It is closer than between this genus and any one of the Heinziidx, becanse of the presence of the line of donble elongated tubercles in the latter.

\footnotetext{
"The Pulchelliblat were not mentioned in my Cephaloporl "hapter in Zittel's Text-howk, owing to the accidental omission in copying of a page of the manuscript.
} 


\section{NICKLESIA n. gen. Hyatt.}

This gems has a prolouged smooth stage, followed by a costated stage, in which the costae are without tubercles and cross the more or less rounded convex renter without becoming concave. In some species, as in the type [L. rumasiuna], the venter does not become decidedly flattened at any stage and the coste are rery slightly developed. The following species, described and fully figured by Nicklès in his Paléontologie dn sud-est de l'Espagne, ${ }^{a}$ can be referred to this section of the genus: Nick moltoi, levyi, nolani, lapparenti.

In other species the renter becomes markedly flattened during the latter part of the smootl stage, and the following species, described by the sanc author, are referable to this section: Nick. zeilleri, malladre, bertrandi.

Nicklesia alicantersis n. sp. Hyatt.

P'ulchellire (Stol. !) pulchella Nieklès. 1890, Mém. Soc. géol. France, Paléontologie. No. 4. p. 13, pl. 1, figs. 10.11.

This differs from d'Orbigny's species in laving regularly dichotomous, more or less sigmoidal costre, a wider umbilicus, less compressed form, and broader venter.

The following species can also be included under this head: Nick. karsteni (Uhlig) ${ }^{b}$ (pulchcllus of Karsten).

Nicklesia lenticulata 11. sp. Hyatt.

Pulchellia aff. pulchella Gerhardt, 1597, Nenes Jahrb. für NIin., Geol., und Pal. , Beil.Bd. XI, p. 15t, pl. 3, fig. 9.

b'Orbigny's species has several short costre between the longer ones, and the internal sections between the longer costations are smootl, whereas in both of the above the coste are crowded together and corer the sides of the shells.

\section{Nicklesia didayana (d'Orbigny).}

Nick. didayana (d'Orbigny), another species of this group, las been often misapplied to species having chamels on the renter and lateral tubercles.

\footnotetext{
a Mém. Sinc. géol. France, Paléontologie, No. $4,1890$.

bernslorfer Schichten, Denkschr. Ki. Akarl. Wiss., Wien, Vol. XLII, Isৎ3.
} 


\section{Nicklesia dumasiana (d'Orbigny).}

Pl. XVII, figs, ti-s.

Ammonites dumusiumes d'Orbigny, 1stz. Voyage dans l'Amérique méridionale, Vol. III, p. 199. pl. 17.

This species is fully figured by dOHbigny, and easily recognizable in case of large specinens. The French specimens that usually bear this name have been retained here with a question mak. The three examples that are in the Ifusem of Comparative Zoology are much smaller than the figures of the South American species, but are otherwise identical, and there are no young forms of the latter for comparison. The young specimen figmed shows the development of the greneric costre directly from a form with a rounded renter, without the interrention of a flat or concave venter.

Loculity: Colombia, Sonth America; Hscragnolles, France.

Age: Neucomian.

\section{SLPPLLCHELLIA 11. gen. Hyatt.}

This becomes a distinct generic group, consistently with the principles adrocated in this and other papers, hecanse it represents a distinet grade in the erolution of the Pulchellielie. Its permanent adult rharacteristics correspond to those of the transient condition of the neanic stage in the young of Pulchellia. Submulchellia oehlevti (Nickless) has a smooth involnte shell, with a concave ventral area bordered hy two ridges. 'The renter on casts is nsually flat and has no definite ridges.

The genus includes also subp. fonmei (Nickless), and Subpr. samougeni (Nicklies.)

Subl. sameageani (Sayn) has lohes and sarldles quite different from the Spauish form as figmed by Nicklès, but whether it or Nicklès's species is identical with Hernite's it is not possible to state. Hermite's original description and figure give no sutmes. The shell as described in correction of the figure. has slight costations, present also in Sayu's, as deseribed but not as figurerl, and not mentioned at all in Nickles's description. The sutures of Nickles's specimens, onc from near Constantine, Africa, and the other from Span, are sinilar, but entirely distinct from those of Sayn's figme. Until the suture of Ilemite's original or of a specimen from the 
same locality hats been investigated, it ean not be stated whether Sayn's or Nickles's species are really the sane as Hermite's. In these smooth forms the shells can not he relied on to show specific differences.

\section{Subpulchella Castelianensis $11 . \mathrm{sp}$. Hyatt.}

Pl. XVII. tigs. 1-5.

The two specinens in the ILseum of Comparative Zoology here described as the trpes of the genus and sprecies are both smootl, rompressed, lighly involute shells smilar to semeageani and others in aspeet, but with denticulations on the anxiliary saldles not found in those species. The largest specinen is a east $28 \mathrm{~mm}$. in whole diameter, probably when romplete albont $40 \mathrm{~mm}$. The imer edge of the living chamber shows on one side and this was abont one-half of a volution in length. The suture figured was taken from the oldest stage of this specimen. The venter in this cast is plano-convex, and there are rilges on the ventro-lateral angles, but these are rirges becanse the lateral zones are faintly coneave, consequently they are ridge-like toward the lateral aspects and not on the renter. The center of the renter has a raised line or piseudo-keel such as is figured by Sayn in his Pul. sauregeani, and is not uneommon in species of Placenticeras. When the shell is present the venter is slightly coneave and it has the usual ventro-lateral rirges. The specimen figmed (Pl: XVII, figs. 1-4) is somewhat younger, but shows a partially completed living chamber a little longer than one-half' of a volution.

Locality: Castellanes, France.

Age: Neocomian.

\section{PULCHELLIA Thlig.}

Uhlig designated three gromps when he described this genus, the so-ealled bicarinated or trne Pulchellia, the group with costre crossing the venter, equal to my Viclilesia, and those with a keel on the renter, the equiralents of the rems Psilotissotia. Nickles reeapitulates these facts and the observations of Douvillé, and joins him in referring the first group to I'ulchellia, imd also in thinking it possible that I'. pulchelle and some others may be referred to Stoliczkicia. Nickles, however, retains these forms under the general name Puchellia, and places the other generic names in brackets. 
He has also traced some differences between the sutures of the different groups, but these are of such a nature that one does not get clear impressions from drawings, although those of Nicklès are remarkable for their excellence and full of instructive details. I unfortmately can not agree with these gentlemen with regard to Stoliczliain.

Nenmarr" states "sehe ich mich geniithigt, eine Gattung fiir eine merkwürdige kleine Gruppe ron Ammoneen anfzustelten, nänlich, für die eigentiimlichen Formen der indischen Kreide, welehe Stoliezka * * * beschrieben und mit den Hällstatter Arcesten rerglichen hat." He then goes on to establish new names for the two Indian species considered by him to be distinct from Ammonites dispar d'Orbigny, and the first of these, Stoliczkaia tetragona Nenmayr or Amm. dispar Stoliezka, ${ }^{b}$ thus beeomes the type of this gemus. D'Orbigny's figure and description of Amm. dispar shows a compressed involute shell with a volution in section like that of Nicklesia pulchella (d'Orbigny), but the costre are narrow, and although they cross the renter they are quite distinct from those of this family. D'Orbigny's species is an old shell of some other gronp, but is related neither to Pulchellia nor Stolic:zicia.

Stol. tetrugonu has a quadragonal volution in section when full grown, venter depressed and slightly convex. sides same, umbilical zone abrupt and narrow. Ribs very proninent and sharp, reaching across the renter and side and having alternating shorter costre across the venter. Only one row of tubereles along the ventro-lateral angles in the young until in the neanic stage. These disappen in the adult. This is precisely the form and general aspect of some of the Mantelliceratide. For example, Amm. mantelli is either a member of this genus or a very similar parallet form. But none of these have costre (1) omaments or chammels like those of Mantelliceratidx. Probably also the young are more or less distinct in development.

Whether this last be true or not, the agreements of the adult sutures are not close enough to place such widely different structureel shells as Stol. tetrayoun, and I'ulchellia pulchelle in the same group, especially when there is close agreement between the latter and the younger stages of the typical $I$ '. compressissima and the suture lines are also similar. 
The keeled smooth forms were also referred by Douvillé and Nickles and by myself in Cephalopods of Zittel's Text-book under the name of Psilotissotia to 'Tissotide, but I am now satisfier that this is an erroneons view of their true affinities, and they are here retained in the Pulchelliidre.

Pulchellia nicklest 11 . ip. Hyatt,

Pulchellia compressinsimu Nicklis, 1590, Mém. Soc. ggéol. France. Paléontologie, No. 4. p. S. pls. 1 and 3.

This species is now, thanks to the drawings and descriptions of Nicklès, snfficicntly well known so far as the neanic and ephebic stages are concerned, and it is not venturesome to say that in the still younger stages the venter must have been romnded and smooth like that of the group here named Psilopulchellia. The true $P$. compressissimn d'Orbigny is a much thinner shell, with broader costa and narrower venter, the costal folds on the renter narower and less deeply chamneled. Doubtless the young are correspondingly distinct. The mubilicus is also narrower. Pulchellia schlumbergeri Nicklès, Mém. Sone. géol. France, Paléontologie, No. 4, p. 38, pls. 7 and 8; Pul. columbiana (compressissima Gerhardt), also figured by d'Orbigny as the young of his Amm. galeatis in the Voyage dans l'Amérique méridionale, $P u l$. selectu, and $I$ 'ul. hettucri also belong to this genns.

Age: Barremian.

There are two species described from Djebel-Ouach by Sayn, Pul. changamieri Sayn and Pul. kiliani n. sp. (Pul. (Heinzia) ounchensis, Sayn, ${ }^{a}$ pars). This last is distinct from Heinzia onachensis Sayn in not having an inner line of tubereles and in its narrower rentral channels as well as in its sntures as described by Sarn.

\section{I'ulchellia compressissima (d'Orbigny).}

Pl. XVII, tigs. 9-12.

Lummonites compressissimux d'Orbigny, 15t0, Terr. C'rétacé, pl. 61.

This species is very peculiar and altogether distinet from the forms nsually placed under the same name by anthors generally. D'Orbigny's figure is very similar to a specimen of the Krantz collection from Escragnolles, the same locality as the shell figmed hy l'Orbigny. The form of this cast is quite as much compressed and involute, the costie are present

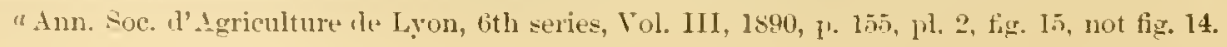


onty on the outer half of the sides, the spaces between are narrow sulcations that cross the renter. The costre cross the renter with undiminished breadth and are chammeled, but this chamnel is so shallow that I at first thought this must be the young of another species with very broad costat, Amm. catillus d'Orbigny. The specimen deseribed is just a little older than the shell figured as compressissimus by d'Orbigny and ribs begin suldenly to bend forward on the last part of the outer volution. Amm.catillus d'Orbigny may also belong to this genus, but the characters of the young, which alone can determine this question, are not kinown.

Locality: Escragnolles, France.

Age: Neocomian.

PSILOTISSOTIA HYatt.

This genus was muluckily considered by me when mentioned for the first time ${ }^{a}$ as a member of the Tissotiidar. In this I was not led by the opinions of Donville and Nickless, but by what I then considered to be its true affinities. It hiss become obvious in studying I'aratissotin, which approaches it nearest in form and in agreement of the development, that this is not a natural association. Nicklès's plates also show that the sutures are similar to those of true Pulchelliidæ. They are involute forms, smootl, and compersed in the earlier stages and having at this time or all throngh the neanic stage a smooth keel that may in older stages become tuberculinted. Costre may be representerl by fine folds as in Psil. mariole Nicklès, mutil a late age, but when they do appear they are heavy, fold-like, and sigmoidal. In this species also a median lateral line of nodes appears. If their real affinities are with this family, as they certanily appear to be now, they can be accomted for as direct derivations of Psilomulchellia which lias evolverl a keel. The intermediate aspect of species like Pul. defforgesi and hangi indicates that the shell did not have a flat ventral area at any stage, but was the rlirect outeome of the evolution of I'silopulchellia.

This includes besides the type, Psil. chumusi (Nickles), the following species: Psil. mariola, defforgesi, reigi, hangi, Nicklès; L'ul. defforgesi Nicklès is described by lim as having sinply a sharp venter, but its affinity with mariolae would bring it into the group and the sharp venter may be merely due to the age of the example figured. 


\section{LOPHOLOBITES Hyatt. \\ Lopholobites cotteaui (Nickless).}

Lentestites ? cotteani Nicklès, 1s!n. Mém. Soc. géol. France, Paleontologie. No. $t$. p. 5t, figs. 36. 37 ; pl. 5. fig. 9.

Lopludulites cotteani Hyatt, 1960. Ceph. Zittel's Text-book Pal.. p. 590.

This is a small, very involnte, compressed, smootl form, with minute umbilicus and subacute venter. The extermal characteristics and sutures indicate this to be at retrogressive but more involute shell, allied to such species as Psilotissotia hangi, figured on the same plate by Nicklès. The sutures are entirely distinct from those of Neolobites, especially in the bifid character of the first lateral saldles and the greater differentiation of the immer saddles and lobes, which are more distinct from those of the outer part of the same sutures than in Neolobites. All of these discrepancies can be accomted for on the supposition that this is a retrograde form of Pulchellia. This also accounts for its small size when nearly outgrown, as in this specimen. Nicklis recognized the great differences hetween this shell and Neolobites, but hesitated to describe it as a different genus because of the great difference in its size. This fear was unfomded, since Neolobites could not have lad a similar set of sutures at any age.

Age: Barremian.

\section{KNEMICERATIDAE.}

The external aspect of the species of this group places them apparently close to the Buchiceratida, but the sutures and the absence of a keel at all stages separate them widely. The first lateral saddles exhibit tendencies to division into several distinct branches, as in the Engonocerntidx, and the outlines of the other saddles and lobes also are similar. 'The division of the first lateral saddles is not carried so far as it is in Engonoceratida. The principal first lateral resulting from the secondary division of the prinitive first lateral is consequently a broad solid saddle instead of the narrow first lateral of that fimily.

Unluckily, the dorsal sutwes were in no case exposed, and the conditions of fossilization in every specimen made excavation impracticable.

The forms, both by their omamentation and general development, are apparenty more sperialized and more complex than those of the Engonoceratida, and although the yomugr was seen in only ons eximple in a section the appearances were the sane as in sections of species of the 
Engonoceratida. It has been therefore assumed that they had a similar stage in which the venter was concare and harl continnous ridges on the ventro-lateral angles.

\section{KNEMICERAS B̈̈lm.?}

There are but two lines of nodes on the sides and straight broal costa, bifurcating between them. The venter is loroad and concave, the costa and nodes are opposite, and the venter is often transversely ridged between the nodes. The ventral lobes have the same slape as in Buchiceras and Roemeroceras and have similar truncated siphonal saddles. The ornamentation and form resemble these genera, but there is no keel at any age and the development is quite distinct. The young are not compressed as in Buchireras, and the ventral zone is concave in an early neanic substage and remains coneave throughout life. This shows similarity to Engonoceras and Placenticerus. The lateral lobes and saddles are similar to those of Enyounccras, but the inner laterals are ferrer in number and the first lateral saddle. are more complicated. The divisions of the first may be counted as four or eren five lateral saddles derived from a prinitive first lateral. Lntil some one ontogeny is studied the correct enmmeration can not be given.

The young were seen in section. The rounded venter' of the nepionic stage is sucueded in the neanic stage by a flat-rentered volution with quadragonal outline, and the concare renter appears in the earliest part of the eplebic stage. At this time the renter is very broad, the sides flat and obriously costated and tuberculated on the umbilical shoulders. Whether there were tubercles on the edges of the renter was not determinable.

At an early neanic substage the umbilicus was open, the renter flat and broad, but narrower than the dorsal diameter through the umbilical shoulders, the lateral zones flat and convergent, the mubilical zones well developed. These chancters and the broad costre and nodes of the later stages and the venter are similar to those of l'ulchelliida, but the division of the first lateral saddles in full-grown specimens and other sutural characters are dissimilar. The species discorered in the Cenomanian of l'ortugal appear's to indicate that the real age of the fossils found at Hount Lebanon is Cenomanian, although, as may he seen by the context, I have doubts whether any of the latter belong to the fauna of the rocks in which they lave been found.

a Zeitschr. Deutsch. geol. Gerell., Vol. L, 1898, p. 200.

ION XLIY-03-10 
Kinemiceras syracum (yom Buch).

Pl. XVI, figs. 48 .

Amm. wypincens ron Bucl, Abhandl. K. Akat. Wism zn Berlin, 1sts, pl. ti.

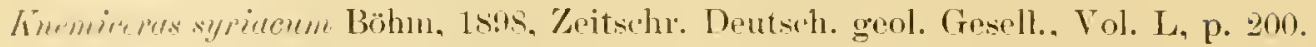

Ion Buch's figures of this species on his pl. 6 are excellent in all rharacters, but his suture line on pl. 7 is either erroneous or belongs to another form.

One gerontic specimen is about $55 \mathrm{~mm}$. in whole diameter, with living chamber nearly one-half of a volution in length. A smaller specimen, 45 mm. in diameter, has also reached into an extreme gerontic substage and has living chamber of same length. Von Buch's specimen, according to his figures, was also in gerontic stage, but evidently somewhat larger, perhaps 70 mm., or thereabonts, when living chamber was present.

This stage is indicated in one specimen as in ron Bucli's figure by the alproximation of septa in pairs as if the individual were only temporarily affected by weakness and then resumed the nsual rate of increase. In one specinen the last sutures are irregularly spaced. The last three next to the living chamber are approximate. A slightly greater interval occurs between these, and there is a pair closely approximated, and apicad of this is a broader ehamber and again a pair of approximated sutures. Apicar of this last pair there is a chamber broad on the venter but so narrow near the lines of involution that the sutures are crowded together on the umbilical shoulder. Apicad of this is the ephebic stage, with all sutures regularly spaced. The gerontic sutures are not always so irregular, and there may lee as many as eiglit sutures showing more or less inequality in spacing, ending with a series gradually becoming closer and eventually overlapping. The whole duration of the gerontic stage, including the living chamber, consists of about three-fontlis of a volution. The lobes and saddles become shorter and the outlines simpler in this stage. Temporary approximation of sutures oceurs often in the growth of these shells, and it is not always a sign that the gerontic stage has been reacher, but when it is continued for some time, as in von Buch's figure, and after a period of prolonged regnlarity in the width of the living chambers, it is obviously due to senility. There are no signs of a row of tubercles on the median aspect of the sides, and there are obrionsly only two rows of nodes with heary fold-like bifureated costic between. 
The nodes contime to increase in length and size throughont life until in the latter half of the gerontic living chamber, when they show a lecided and rapid decrease on the renter but persistently increase on the umbilical shoulders nutil near the end of this chamber. The living chamber was incomplete on the renter in all of these specimens, althongh in several it was complete near the umbilicus and somewhat over one-fourth of a rolution in lengtl.

The first lateral saddles are bifid, having two broad arms, and botl of these are again faintly bifurcated, these subdivisions being minntely denticulated on the edges in perfectly unworn sutures, which can be found best by removing encrusting ostreans. In some sperimens the second lateral sadelle does not split up completely from the tirst, and insteal of three principal lateral siddles there are bnt two, as shown in Pl. XVl, fig. 5. In otlees the division is complete, as it probably is in the linter stage of the specimen shown in Pl. XY', fig; 8. No specinen so fill seen carries out the complete division of the remaining first lateral, althongh in sone the median marginal lobe is quite long. It is a "mions fact that all of these specinens-eleven in number and collected from five different sinreesshonfl have encrusting bryozoa and ostreans on the exterion of the cast and all more or less wom on all other prarts of the surface. The lohes and saddles nowhere exhibit, and it is not likely that this species erer exhibited, the peculian lobes and saddles figured by rom Buch on lis pl. 7. The entire suture seems to be incorrect for this species, whereas those given in pl. 6 are right so far as they go, although taken from the nsual worn surfaces, of casts. Böhm's figure, qunterl below, is uncurate, but belongs to an older stage than that figured in this work. The second and sixth hateral saddles are bifid, the serenth and eighth broad, flattened, and entire. There are marks npon unworn sutures indicating the presence of slight denticles on the edges of the principal saddles, but no such divisions and prominent marginals as in von Buch's fignre, pl. 7. The ventral lobe has two arms as in Engonoceras; the dividing siphonal saddle is apparently flat, but when elearly defined it has a diminishing base divided by a minute siphonal lobe. Faint denticulations are present on both this saddle and the sides of the arms of the ventral lobe. The lateral lobes are club shaped, denticulated on the top, but entire on the sides near their base between the phyllifom bases of the saddle. There are inegular trifid 
ontlines such as appear in Bïhm's figure, ${ }^{a}$ but there are also regular trifid bases to the first lateral saddles. The former arise from the irregular growth of the marginal saddles of the first or outer (originally bifid) arm of the first lateral saddle, making sometines a simple triple division, and sometimes this onter arm itself becomes trifid, equally or more or less unequally, as in Böhn's figure. The variation of the sutures is very considerable in this species, but there seems to be, so far as nyy material reaches, no sufficient groumls for the separation of specimens having trifid first lateral sadtles from those haring this part bifid. In fact one specinen shows early in the ephebic stage a hifid first lateral on one side and a trifid saddle on the other side of the renter, i. e., the two arms of the first lateral on one side are regularly bifid and on the other the inner arm is trifid and the outer arm bifid. Oecasionally this onter arm may have four marginals. In one specimen the imer arm is bifid and the outer arm lass three minute margimals. In one specimen again (Pl. XVI, fig. 5) there are three arms. each regnlarly subdivided by a merlian marginal lobe. This satdle can perlans be best described in general terms as having three arms derived from an original bifid form and usually preserving a record of this original form in the shortness of the onter marginal lobe as compared with the second marginal and also in the usually hifid ontline of the base of the third or imermost arm. Often, as in I'l. XYl, fig. 8, the imner arm is sufficiently separated to be counted as a second lateral saddle.

The specimen described by Hamlin in Syrian Fussils ${ }^{b}$ is fine only on one side and the supposed shell "the thin test almost entire" does not exist. Hannlin was misled by the smooth surface and the presence of a thin brown layer. That this is not the shell is shown by the sutures, which are somewhat worn, not showing the denticulations plainly. The living dhamber is obvionsly nearly complete and is a trifle less than one-half of a volution in length. I lave examined twentr-two specimens of this species and not a single one had even fragments of the shell preserved and many were incrusted with ostreans and bryozoa. There is no positive proof that these ammonites were living menlbers of the funna in which they were found, but there are obvious reasons in their aspect

"Ueler Amm. peternalis: Zeitsch. Teutsch. geol. (iesell., Vol. L. 1898, 1" 149.

b Mem. Mus. Comp. Zool., Vol. X, No. 3, 18st. p. 11 
and in the presence of these incrusting growths on the casts for consiclering them as laving been fossil casts when the incrusting animals grew upon them.

Locality: IIomnt Lehanom, Srvia.

Age: Cenomanian.

KNemiceras Compressum 11. sp. Hyatt.

Pl, XVI. figs. 9. 10, 15-18.

Ammonites nibreyermus Hamlin, 198t, Menı. Mus. Comp. Zool. Vol. X, No. 3, p. 12.

The trpical form of this species is separable from the variety sulcompressum in full-grown specinnens by the greater compression of the volutions, namower venter, and lesi development of the nodes on the mmbilical shomlders. The proportionate increase by growth of the rentrodorsal dianeters is also greater with relation to the transverse than in the stonter variety described below, and in all these respects it differs still more from Knem. syriacum. 'The shell, however, until 45 to $50 \mathrm{~mm}$. in diameter is not distingnishable from the shell of that species. As stated by Frats and Hamlin, the sntures in the wom casts are similar to syriacum, but in a large specinen of the same size as the trpe of this species (I'l. XVI, fig. 15) in the IInsemm of Comparative Zoulogry these are less wom than usual and full grown. These sutures (PI. XVI, figs. 17, 18) show the large ventral lobes, which acenpy nearly the entire breadth of the venter instead of only the eentral part, as in the stouter variety and in syrincum. The laterial saddles and lobes are very long and namo and the bases of the saddles swollen, rounded, and phylliform, resembling those of sphenorlisens. The apical ends of the saddles are also similarly shaped, broard, denticulated, and cutting deeply intu the saddles. In the gerontic stage the lobes and saddles become shorter' again, as in the younger stages, and more like those of syriacum. 'The most perfect cast (Pl. XVI, figs. 15, 16) is $70 \mathrm{~mm}$. in diameter, without living chamber, the nuter volntion 38 mm., the nmbilicus $10 \mathrm{~mm}$, and same rolution opposite $22 \mathrm{~mm}$., the thickness of the last being 13 min. between costa.

The largest specimen is from lieirut, No. 10902G in the collection of Columbia University. 'This lus no living chamber, and the actnal diameter is $85 \mathrm{~mm}$, estimater dianneter about $90 \mathrm{~mm}$. Diameter when living chamber was present could not have been less than $130 \mathrm{~mm}$. 
Sutures are considerably wom, except in one place at dianeter of $75 \mathrm{~mm}$, the volution being $23 \mathrm{~mm}$. ventro-dorsal diameter. These were similar to those of the typical specimens, except the first lateral saddles, which were narower and distinctly bifil: the immermost inflections were not seen.

The nodes were present on the umbilical shoulders, but apparently disappear on the last half of the onter volution, but this condd not be proved on account of the stite of this fossil.

The venter remained concave to the end. The ventral tubereles became, however, much finer and more closely set than in the ephebic stage, and I should think more perfect specimens might show the correlative disappea:ance or olsolescence of the costations. I doubt if the costa are ever so broad in this species as in syriucum. The state of these fossil casts tends to confirm the opinion that they were not living members of the fauma with which they were found.

Out of the eight casts in the Inseum of Comparative Zoology only three were suitable for observation, and all of the three more or less imperfect, and there was not even the minutest piece of a shell on any of them. The same is also true of the large speeimen from the collection of Columbia University.

Knemiceras compressum var. sUtcompresscm Hyatt.

Pl. XVI. figs. 11-1-t. 19.

Amm, syruecus (pars) von Buch. Abbandl. K. Acad. Wiss. zu Berlin. 18ts (not figured).

Amm. syracus (pars) Conrad, Lynch's Exp. Dead Sea and fordan. 1852, pl. 14. fig. 7t. two upper figures (not tig. 6).

This variety has heretofore been confonnded with Knem. syriacum, from which it is, however, easily separated. The form even in extreme age is more compressed, the nodes on the umbilical shoulders are not so prominent, and the renter and transverse diameters do not broaden out in the later ephebic and gerontic substages, as in that species; the nodes also on the edges of the venter are longer and narrower than in that speeies. The sutures are very similar in these two forms.

A specimen from Mukhtara, Syria, in the American Mnsemm of Natural Fiistory, New York, reaches $97 \mathrm{~mm}$. diameter without living chamber, and shows that the shell sometimes reaches a larger size than $115 \mathrm{~mm}$. in diameter. 
A specimen in the Museum of Comparative Zoology is $50 \mathrm{~mm}$. in diameter. This retained its flatter sides and proportionally broad renter to the end of the last rolution. The living chamber is inconplete and somewhat less than half of a rolution in length. A specimen from Abeih, Mount Lebanon, in the Inseum of Comparative Zoology, $53 \mathrm{~mm}$. in dianeter, has a living chamber obviously rery nearly complete and somewhat less than half a rolution in length. This is therefore approximately the length of this part. One of the specimens in the Krantz collection in the Museum of Comparative Zoology shows thick shell on renter where it has been covered and protected by outer volution. Outside of this the cast is wom more or less, and there are absolutely no remmints of shell under the encrusting ostreans that occur on the exposed parts. The condition, in other words, proves that this and probably other fossils mentioned above were not living members of the Syrian fanna as heretofore described, but came from some earlier epoch and were already in the condition of fossil casts when the incrusting ostreans grew upon them.

Loculity: Gilead Mountains east of Jordan, Mount Lebanon, Syrria.

Age: Cenomanian

Kinemiceras attenuatum (Hyatt).

Pl. XV11, figs. 13-15.

Buchiceras attenuatum Hyatt, 1875, Proc. Boston Soc. Nat. Hist., Vol. XVII, p. 370. Glottoceras attemuatum Hyatt, ibid, note.

The sutures agree quite closely with those of Knemiceras compressum, but the altemating tubereles on the edges of the renter and the form of this part are essentially Engonoceran.

The original specimen is $65 \mathrm{~mm}$. in diameter; it is a cast without any vestiges of the shell. The ventral lobe is deep and narrow and like that of Knemiceras The first lateral saddle is also Knemiceran in outline. It is mequally divided into three parts. The outer arm is trifid, but with such slight marginals that they are merely sinuosities. The central part is a minute saddle, and the inner has a trifid base. The second lateral is phylliform and so faintly bifid that I was not sure of the fact. All the remaining saddles are subphylliform, with broad bases and symmetrically bifid, except the serenth and eighth, the last on the line of inrolution. These are entire. The first to the sixth lobes are simple and denticulated; the seventh and eighth are entire. 
This species was named erroneously Glottoceras in a note quoted above and alcidentally left uncorrected in the proof.

The great regularity of the outlines of the bifid saddles and the small dividing marginal lobes are probably characteristic, as well as the fineness and number of the tubercles of the outer lines and the presence of a third line beginning, apparently, on the latter part of the outer volution.

Locality: Celendin, Peru.

Age: Cenomanian?

\section{Knemiceras gabbi n. sp. Hyatt.}

Pl. XVIII, figs, 1-3.

Ammonites attenutus Gabb, 1877. Jour. Acad. Nat. Sci. Philadelphia, 2d series, Vol. VIII. p. 26t, pl. 36, fig. $1 "$ and $b$.

'The originals of Gabb's figures lave not been found in the collections of the Academy of Sciences of Philadelphia and I could not olbtain them for comparison, but the suture line figured by Gabb is distinct from that given on Pl. XVII of this work, and Gabb's form is much stouter at the same age, has larger nodes and a broader venter. The old age with a rounded broad venter is probably not particularly distinctive, althongh it may perlaps be that this change never occurs to such excess in true attenuntum as it does in yabbi.

Locality: Quebrada de Huari, Peru.

Age: Cenomanian?

\section{ḰNemiceras uhlifi (Choffat).}

Placenticerus uhligi Choffat, 1898, Faune Crét. du Portugal, Vol. I, 2d series, pp. 4

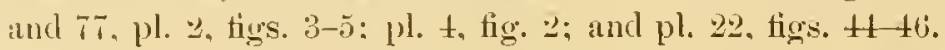

This is a compressed species similar to $K n$. compressum, but differing in the sutures. The saddles are very broad and lave flat bases with more denticulations. The lobes are more like those of compressum, but the inner ones are quite different. The marginal divisions are less complete than in compressum.

Locality: Portugal.

Aye: Lower Bellasian (Cenomanian.) 


\section{ENGONOCERATIDA.}

Shells apt to be involute. The venter is concave and is occupied for its entire breadth by a smooth zone. The sutures are variable in the different genera and approximate in some forms to those of Sphenodiscus. There is a sinilar tendency in most of the species to have broad saddles with phylliform bases, which are either entire or bifid, while the lobes have narrow bases and are more or less expanded apicard and apt to lave trifir termmations. The simplicity and shortness of the saddles and lobes is corpelated with the tendency to produce a nuch larger number of inflectrons and great variability in the ontlines in the same species and sometimes tren on lifferent sides of the same specimen. The ventral lobes are short, spreading apically, and have usually pointed short and entire siphonal saddles.

\section{PROTENGONOCERAS Hyatt.}

The ephehic form is compressed and involute, as in Engonorevas and Metengonocress of the same subfamily groml, and it is also similar tw the neanic stages of Enyonoceras, Sylhendiscus, and Placenticeras.

The shell is smooth, except in the gerontic stage, where folds appear. The rentel is moderately broad and deciderly concave, bordered by sharle, smooth ridges. These are exactly the external characters of the romg during neanic stages of the species of the different genera mentioned.

The sutures have the same rentral lobes as in Engonocerrs and Metenyonoceres, and similar lateral sutures, but the saddles are rery broal and short and the lobes have fewer marginals.

Type, I'rot. gabli (Bölnu), Whitney collection, in Mnsemm of Comparative Zoology.

The septa follow internally the curvatures of the sutures, concars along the mesal plane and convex only on the areas on each side of the zone of involution.

Protengonoceras gabib (Böhmi).

Pl. XVII, figs. 11;-20.

Ammonites pelemalis Gabh, 1869, Pal. California, Vol. 1I, pl. 35, figs. 1, 1a. Engunucerms yubbi Böhm, 1898, Zeitschr. Deutsch. geol. Gesell., Vol. L, 1. 197.

A cast of one-half of a rolution in Musem of Comparative Zoology from Professor Whitrey shows ephebic stage. The wiole diameter, partly 
estimated, is $69.5 \mathrm{~mm}$., the outer portion of this rolution, partly estimated, is $42.5 \mathrm{~mm}$., the umbilicus is $5 \mathrm{~mm}$. and the opposite part of same volution is $22 \mathrm{~mm}$. The shell is present on the venter but not on the line of involution. Greatest transverse diameter of outer volution is $25 \mathrm{~mm}$., the inner part is $11 \mathrm{~mm}$., both through the umbilical shoulders, shell on one side and not on the other side. Probably shell would lave nade the difference of $5 \mathrm{~mm}$. in each case.

This is a compressed shell, closely similar in aspect to Engonoceras udderi and the ephebic smootl stage of Protengonoceras? emarginatum, but the involution is greater; the costations in this stage are fainter, but can be plainly enough seen both on cast and on the shell in a cross light. They are less than in Gabb's figure, but the form of venter and aspeet of shell, including amount of involution, shows that we are dealing with Gabb's species. There are also no tubercles on the mmbilieal shoulders. The first large fold is partly present on the broken edge of the onter volution in the small fragment figured, showing the begimning of the gerontic stage. The venter is decidedly concare with slight ridges on either side. This form of venter is found in the neanic stage and the whorls, although stouter, are similarly compressed when the whole diameter is only $13 \mathrm{~mm}$. At dianeter of $+4 \mathrm{~mm}$. this venter, although almost as broald as the transverse diameter, is already like that of the adult, but may be a little flatter.

Other details could not be seen. It is obvious that the young aequire the concarity and sharp lateral ridges of the renter in an early neanie substage at a time when the volution becomes flattened on the lateral zones. The form is then obvionsly like some stonter and less involute forms of this genus not yet discovered.

The sutures are very slightly flexed apicad: the saddles and lobes closely similar to those of Metrugonoceras.

The renter is slightly asrmmetrical; the first pair of saddles on the right are divided by a rery slight marginal lobe. There are nine saddles. and eight lobes on the right side, the seventlı saddle alone being bifid. The marginal lobe dividing this saddle appears on the earliest suture of this volution. Lobes on the left side of a more arlvaneed stage show that this simplicity is due to age.

A larger specimen, same locality, in the gerontic stage, is $108.5 \mathrm{~mm}$. in diameter and has the shell preserved. Outer part is $57.5 \mathrm{~mm}$., umbilicus 
7.5 mm., and opposite side same rolution 46.5 nm., no shell present. The greatest transwerse rimmeter of the volution is $30 \mathrm{~mm}$, and of thesmaller part opposite is $22 \mathrm{~m} 11 \mathrm{~m}$.

The shell is malked by hands of growth and fold-like olscure costre which appear in the gerontic stage. These terminate at the umbilical shoulders, aul along the centran surface of the lateral aspect have very broad swellings and then subside into the flat general surface toward the periphery. The renter is slightly broader than in the ephebic stage above describerl and the rolution stonter, owing to the development of lateral swellings and the slight decrease in the involution due to old age. The umbilical shoulders and the nmbilical zones are abrupt instead of being rounder and sloping as in the adults. The living clamber is complete near the line of insolution and is about one-half of a rolution long internally and apparently about the same externally when restored. The concarity of the renter is maintained for one-half of the length of the living chamber. Berond this it conld not be followed, but there are some indications of the possible romding of the renter in extreme age.

The sutures are quite distinct from those of the ephebic stage in the specimen a hore described. There were eight saddles and seven lobes to the umbilical shomlders, rentainder on the umbilical zones being concealed. The interesting fact, however, can he noted that in this gerontic stage new saddles and lohes were not added as the sides broadened. The increase of the sides was met by the lomdening ont of the saddles. The first laterals were very broad, the second and third had not changed nuch, but beginning witl the fourth they becane iregularly loroder toward the mubilicus, and the seventh was $6 \mathrm{~mm}$. in hreadth, whereas the sixth lobe was only about $1 \mathrm{~mm}$. long. The lobes remained about the same as in the adnlt stage.

The form of the rolutions, smooth concave renter, slightly costated sides, with large folds only in gerontic stage, and primitive sutures all show that this is a species like the similar stages in the development of tuberculated forms in Hetengonoceras and also similar to the youmg of Placenticeras. It is, howerer, a deeply involute shell and is not therefore by any means the most prinitive form of its own subseries. It indicates the existence of a distinct subseries having similar smooth concave venters and less involnte or more discoidal shells, which in the gerontic stage become stouter with 
gibbous sides and have also comparatively flattened or rounded and much wider venters.

Having been lomed through the kindness of Dr. Pilsbry another specimen of this species from the collection of the Acallemy of Sciences, Philadelphia (Pl. XVII, fig. 20), I can state the following additional particulars: The diameter is about $82 \mathrm{~mm}$., pantly" estimated. 'The living chamber is one-half of a volution in length on the periphery, but is much shorter on the line of involution, owing to the great apical trend of the aperture. This has a broad but rery slight sinus on either side and apparently no lateral crests on the sides that comld be separated from the rostrum. This last, however, was broken and conld not be decisively determined. The specimen is in its rerontic stage and npon the inner parts of each sicle has fom heavy folds which disappear near the venter. The bifidity of the intemal suldles is ririable, since in another specimen in the collection of the Mrusem of Comparative Zoologr the sixth saddles were bifid.

Loculity: Arivechi, Sonora, Mexico.

Age: Fredericksburg group, Comanche series.

Protexgonoceras J'lanum 11. si. Hyatt.

Pl. XVIII, figs, ti-9.

This species is described. from a fiagment which womld be orlinarily insufficient for diagnostic work. 'The greatest lengtl of this piece is only 2.5.5 mm., the ventro-dorsil diameter of the volution 14 mul, the greatest dianeter at umbilinal shoulders $5.5 \mathrm{~mm}$. Nevertheless, the cast is perfectly smonth, the sides that, and the venter, which is only 1 mm. in wilth, is also snowth, concave, and hicarinate. These characteristics, especially the attennaterl venter and smonth sides, distinguish it quite sufficiently from the preceding species to justify specific separation. There are ten sardles, all nalrow, the first symmetrially bifurated, as in other forms of this genus and Engonoceras. They are entire and from second to eighth more or less (abl) shaped, hut the ninth is bromler and lifid. The tenth and eleventh are entire, oceupying the mubilical zone. 'The dorsal zone of impression has six saddles, eomting the ontermost one above mentioned (Pl. XVIII, hig. 9). There are ten narow zygous extemal lobes (Pl. XTIII, fig. 8) on the right side. The first is club shaped and entire, the second to the fifth similar, but faintly trifid. 'The sixth to the tenth are shorter and decrease 
in length to the line of inrolution and are entire. On the opposite or left side there are ten sadiles and eleven lobes. The tenth saddle is completed, and there is a small lobe on the line of involution. The first saddle is narrower and the eighth and ninth saddles broad, and both similar to the ninth on the right sicke in being bificl. On both sides the first fire lobes are long, and the sane change occurs in the shortness of the sixth and remaining lobes and saddles. The matrix is similar to that which oceurs in the Colorado formation at Horton's mill, Dallas County, 'Tex.

Locality: 'T'exas.

Age: Stanton suggests Upper Cretaceons from the matrix.

Protengonoceras ? emarginatum (Clagiui).

Sphenodiscus emurginutus? C'ragin. 1593. Geol. Surs. Texas, Fourth Anu. Rept., p. 245 .

This species is describer as having straight distinct rentral channel at the diameter of $90 \mathrm{~mm}$. and also as having tro rows of feeble tubercles, one on the umbilical shoulders and the other midway on the lateral aspect. The bilobed saddles mentioned hy Cragin indicate a more complicated suture line than oceurs in Protengonnceras as far as known, but the condition of the venter indicates that genus.

Tot having seen auy specimens of the species, I can not say positively that it is a nember of this genus.

Locality: 2 miles south of Pleasant Point, Tex.

Age: Conmanche series, Walnut beds.

\section{ENGONGCERAS Nemmay"}

Althomgh the descriptions and figures of Enyonoceras pievdenale led me to believe that this species had an acute renter, Böhm ${ }^{b}$ has stated, after stud ying the fragmentary originals, that these had truncater concave renters, bordered by ventro-lateral ridges or elongated tubereles, and that the species upon which the genus Eugonoceras was founded, Amm. pierdenalis r. Buch, closely resembles lis Emg stolleyi. The two fragments figured by Bölum do not show conclusively that this is the fact, but it appears to be safest to follow him in the effort to give stability to ron Buch's name and Nemmayr's genus. Ton Buch's and Roemer's rescriptions lead to the belief that the

a See p. 177, where this species is referrerl to Engonocerus.-T. W. S.

bUeber Ammonites pedernalis v. Buch: Zeitschr. Deutsch. geol. (iesell., Vol. L, 1898, p. 153. 
shell casts they described had acute venters, but this is probably an error. In studying this group of fossils such a mistake is easily mate, owing to the simplicity of the sutures, the narowness of the flattened venters, and smoothness and symmetrieal aspect of the fossils, although considerably worn and altered by abrasion.

The presence of three distinct lines of nodes, the flatness and nodose edges of the venter throughour the earlier and ephebic stages, the broarl and often zigzag outline of the renter in the gerontic stage, eaused by the extra development of the outer line of alternating nodes, enable one to separate the species of this genus readily from those of Metenyonoceras, notwithstanding the elose similarity of the sutures. The young during the neanic stage are compressed, involute, and smooth, with concave venter and form like Protenyonorevas. Von Buch and Neumay both describe the prineipal saddles of Engonoceras pievdenale as bifid, and this oceurs in the speeies liere supposed to represent Engonoccres, but does not oceur, so far as known, in Metengonoceras. All specimens so far seen have been easts, either entirely naked or with only the nacreous layer partly preserved.

The attention of collectors is ealled to the fact that some of the species bear no convincing marks of having been autochthonous members of the famuas in which they are liabitually found.

This genus differs from Neololites only in luaving denticulated lobes, if the figures of the sutures heretofore given correctly represent their outlines.

\section{Engonoceras heltiderense (Cragin).}

Pl. XVIII, figs. 4,5 .

Ammonites Jutriderensis Cragin, 18:4, 1595, Am. Geol.. Vol. XIV, pl. 1. tign. 3-5̆; Vol. XVI, p. 369.

Buchiceras (Sphenodiscus) betriderens. Crangin. 1900, Colorado Coll. Studies, Vol. VIII, p. 27 .

Through the kindness of Professor Cragin I have seen some specimens of this species, and one of these has been given in the figure. This alone was not much erushed, but the sutures could not be made out. The aspect is similar to that of Eng. uddeni, but the sides and renter are Hatter and smoother. There are similar nodes on the umbilical shonlders and those on the edges are alternate; there are nascent folds on the outer part of the sides. It reaches a larger size than other forms before it begins to acquire 
the usual gerontic characters-that is, before the venter becomes convex and nore or less zigzag in outline. 'The type of Cragin's species is the small specimen referred to above. This has sutures with numerous small saddles closely set on the suture line, and, so far as could be seen, one of Cragin's fossils of the same lot with that figured had similar sntmes. Cragin describes this species as having a row of tubercles that may be dereloped on the inner ends of the low folrls or costre occupring the outer half of the sides. There are some rery obscme signs of the existence of such markings in these fossils also. These are doubtful even to the touch and are not visible to the eye. This may be owing to the condition of the fossils.

Locality: Belvidere, Kans.

Aye: Champion bed and Kiowa shates, probably near base of Washita Comanche series, Lower Cretaceoms.

\section{Fingonoceras idDeni (Cragin).}

Pl. XIX, figs. 1-7).

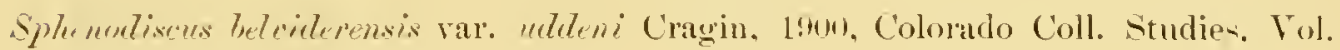
VIII, p. 30. pl. 1, tigs. $3,4$.

A fiagmentary east in iron pyrite, No. $231+\%$ U. S. National Mnsemu, Pl. X1X, fig. 4,5, shows a few of the last sutures and a portion of the living chamber. The diancer, partly estimated, is about $82 \mathrm{~mm}$, the outer volution is $44 \mathrm{~mm}$., the unbilicus $8 \mathrm{~mm}$, the same volution opposite from line of involution to renter 30 mm., no shell being present. The form is compresserl and highly involute, hut slightly stouter than in the more compressed emarginatum. There is only one line of nodes, those on the umbilical shoulders. The costre are fine, and like elevaterl biuls of growth gathered to a foens at these nodes. They are sigmoidal with single fine lines between the nodes, externally more pronomeed folds appearing. in the bater gerontic substage, but no nodes are present on this part in this specinen. The venter is flattened mutil near the last part of the living chamber, which is distorted throngh compression.

The part of the living chamber preserved indicates that it was mot less than half a rolution on the umbilical side. The ten lobes and eleven saddles nu both sides are very similar in outline to those of emaryinatum. The seventh and eighth Jobes on both sides ane bifid. 
The ventral and also the first lateral saddle are asymmetrical. These have the usual form but are rather narrow. The internal parts of the sutures are deflected orad towarl the umbilical shoulders so that they rise materially, giving them a pecular aspect in this specimen. The lobes are similar to those of emarginatum, but are narrower and shorter and the saddles broader and shorter in proportion. The second to the sixth saddles are entire, the seventh to the ninth bifid, and the tentl saddle is on the line of involution. The sutures are the same on both sides of this specimen. The lubes are inegularly hifid.

There is a fragment of a laiger size consisting of one-fourth of a volution with stouter proportions, laheled "Locality 1490 U. S. Geological Survey, north of Pottsboro, Tex., Cpper Comanche (Grayson)," that may belong to the same species, but the sutures and aspect are distinct enough to belong to a different species ${ }^{a}$

The inner line of large nodes and the median lateral are present, but no outer line, and there are similar distinct costations.

The venter has a similar outline also, but the specimen being larger and older, the venter is more rounded.

The sutures are similar, except that the inner arm of the first lateral saddle is much narrower and entire, the outer arm is distinctly bifid, making the whole outline approximately trifid, the remaining saddles are longer and distinctly phylliform as in Sphenodiscus, and the lobes are correspondingly. broarler apically as in that genus. These effects may perhaps be due to the greater age of the specimen. There is apparently the same number of libes and saddles. There are nine saddles visible on the broken end, right side, and there may be one more, making ten saddles and nine lobes.

A fragment obtained from Dr. F. A. Udden, locality northeast of Little River station, Rice Countr, Kans., is the original specimen used by Cragin and is figured below on Pl. XIX. It is in fine state of preservation, being fusilized with iron pyrite. The breadth of the side is $53 \mathrm{~mm}$., the greatest transverse diameter is at about one-third of the breadth from the line of involution and is $20.5 \mathrm{~mm}$. The venter is very narrow, about $3 \mathrm{~mm}$. in breadth: it has no obvious nodes, but, as in the type, faint undulations may be felt with the finger on the rentro-lateral angles. The sutures are quite different, but lave the same general character. The first lateral saddles are quite distinct on the two sides, owing to the asymmetry of the rentral lobe. 
The sixth sadtle on the left side is bifid: the serenth is broad and srmmetrically and deeply bifid, looking like two entire saddles: the eighth has a large, slightly bifid, onter and a tongue-shaped inner arm: the tenth is bifid. The ninth and tenth can be reckoned in several different ways on account of the peculiar formation of the lobes, either as above, or the imer arm of the ninth be called the tenth and what is here named the tenth can be classed as the eleventh, or, on account of shortness of the lobes, the whole may be considered as a single broad saddhe with three arms, the onter and inner arms bifid and rentral arm narow and entire. The eleventl saddle is trifisl and broad, the twelfth and thirteenth entire, and the last is on the line of involution. On the right side the first lateral saddles, on account of the asymmetry of the ventral lobe, are narower and the second is much reduced. The second to the seventh are entire, the eighth and ninth are symmetrically bifid, the tenth to the thirteenth are entire. The tweltht and thirteenth saddles alone correspond or are symmetrical, bilateral on both sides of the body. The lobes have a tendency to become irregular at their terminations and are long and narrow on both sides and more alike than the saddles.

There is also a large fragment of an example of this species in its gerontic stage, or of an undescribed s!lecies, associated on same mount with E. suljectum (No. 10755 Collection Boston Society Natural IIistory). The dianeter from line of involution toward venter as far as fragment goes is $68 \mathrm{~mm}$. There are only a few nillimeters wanting externally, since part of the first suldle is present. There are apparently nine wathles only on the side, all entire except the seventh, eighth, and ninth, which are bificl. The first to fourth lobes are long and namow and the saddles stont but phylliform. 'These sutures belong obriously to a very aged shell, since out of nine sutures risible the eighth is the first that does not slightly overlap and the last four overlap progressively more and more.

The absence or very slight development of the onter lines of nodes and the absence of distinet ridges on the rentro-lateral edges of the venter distinguish this species from $E$. subjectum. T'he sutures of these two run closely together, althongh the saddles and lobes of this form are somewhat stonter and broader at the same age than in E. suljectum.

Locality: Me.'Pherson ('ounty, Kans.

Age: Comanche series, Kiowa shales.

ro: XIIV- $03-11$ 


\section{ENgoniteras serpentixun (Cragiil).}

Pl. XIX, figs. i-1t; Pl. XX, figs, 1-5.

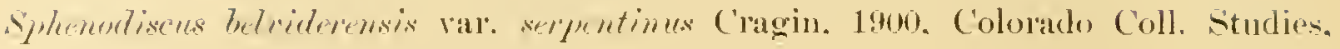
Vol. VIII. p. 31. pl. 2. tigs. $t$ ti.

Three casts of this species (Loc. No. 1489) are well preserverl in a matrix of hematite. The diameter of one $(1489 \mathrm{~b})$ is 58 mm., the volution is $29 \mathrm{~mm}$, the unbilicus $7 \mathrm{~mm}$. : the same volution opposite, measured from lines of involution to venter, 22 nm., no shell being present.

The involution conveys the larger part of each outer whorl, but the internal volutions are plainly risible in the umbilicus and the involution is obviously much less in the vomiger stages than in adults. The volutions are much compressed. The renter is, however, flattened and slightly concave in the ephebic stage, and in the gerontic stage it becomes asymmetrical and sinuous though the development of the large tubercular terminations of the alteruating costre. In the ephebic stage the costre are sigmoidal and only slightly developed; in the gerontic stage these become broad on the outer parts with an external and internal line of nodes, and become obscure interually or umbiliead of the second row of nodes, but they are obviously confluent to the internal or third line of smaller nodes on the mmbilical shonlders. These nolles, like the costre, cone in on the casts at a lite ephehic substage, the side of the younger whorls being smootl. The tubercles of the outer line in the one specimen (1489) b) are sharper and the costre at the points convergent, whereas in the second specimen from the same locality the latter broaden out and the tubercular terminations are more elongated This, howerer, resembles those of the other specimen in the ephebic and anagerontic substage, the narked elongation coming in with the metagerontic substage.

A similar lisposition to broadening out of costat is also observed in the larger specinens in extreme age, but is mot su marked and the renter also remains narower. The living chanber is not complete, but it must have been about one-half of a colution in length on the line of involution. Other. specinens show the same, but none give the outer marowins. The inner lines of tubereles remain close to the umbilical shoulder, receding ontwarlly reory sliglutly in extrene age. 
The variation between different specinens in external aspect of the casts is not great except in the geroutic stage owing to the greater or less development of the molose costations, hut the variations in the sutures are such that no two specinens are alike.

The fourth suture on right side of figured specincu las eleven lobes and ten saddles, and is only slightly cmred apical. The amms of the ventral lobe are seen cutting deep into the lateral aspect. The imer branch of the first lateral saddle is broal, entire, and chb-shaperd, as are all other saddles, except the ninth and tentl, which ane bifid. The depth and size of the lobe that divides what is lere assmmed to be the first lateral is so like other lobes that it is not always ensy to determine whether. it is a marginal or really the first lateral lobe. The lobes are all chubhed; that is, narow orad and swelling-ont apicad, and from first to seventh show very faint digitations or indications of from three to fom very mimute incipient marginal lobes, the tifth showing the equal and the remainder the unequal numbers of these.

Specimen 1489a las short lohes and correspunding saddles like the above, but narrow outer branches to the first lateral saddles and arms of ventral lobe handly appanent on the lateral aspect. There are eleven lobes and ten sambles easily distinguslable, i. e., not overlappling and similar to

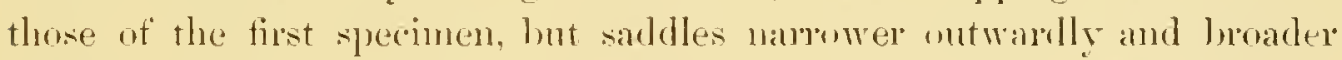
inwardly, and, what is more remarkable, the serentl, ninth, and tenth are bifid, the eighth, which is bifid in the first specinen, being entive in this.

Specimen 1489 e has such distinct sutures that one hesitates to place it in the same species with those markerl 14r9a and 1489 b. The sutures are more deeply rouved apirad, the onter five saldles and lobes longer and namower, and the imer ones brander and flatter. There are, howeres; eleven lobes and ten saddles visible, as in the othors, and the age is about the sime. The sutnres are, however, closely approximated, so that the lobes slightly overlaje even in the ephebic stage and form columms except alomgre the lines of the first to tho serond. The minth saldle alone is bitid, all others being entire.

The discoidal aspeet of the young in the mubilicus am be plainly seen in this specinen. The sutures an the left sirle lave the same general character, hut differ in details from those of the right side. 'The onter' saddles arre alike, but the inner ones are narrow and more mumerous. 
The fragments from l)enison comsist of an almost entire gerontic living chamber and one somewhat mone imperfert one of the same age, a smaller frament of part of ephehic living rhamber and last suture. 'This last shows that in the ephebic stage the renter is smooth, narow, concave, and las no tubereles, but is bordered by two smootl ridges. There are nine lobes and nine saddles, the seventh and eighth saddles heing bitid. 'The line of involution is oecupied by a minute lobe, as it is also in other specimens. 'There are five dorsal lubes between this and the antisiphonal lobe on each side. The first dowal saddle next the antisiphonal is entire, the second and fifth are bifid, the rest are entire. 'The third dorsal lobe was bifid, the remainder on both sides of this were entire and narrower. 'The antisiphonal lobe was narow and bificl. The sutures of an early ephehic or late neanic substage in one of these showerl that the notation of the saddles in this gromp is correct, and that the first lateral has, as stated, two mequal arms, the inner heing really an alrentitions saldle derived from the inner side of the first lateral. 'The mrer saddles and lobes are similar in outline to those of smme specimens from northeast of Gainesville, but the inner saddles and lohes are shorter and broader.

A specimen from Denison, kindly lent me by Prof. F. IT. Cragin [is also figured and is probably one of the types of his variety serpentimus now Jaised to specific rank].

This species is distinguishable from others he the extremely late stage to which the protengonoceran venter-i.e, the concare renter bordered by two rirlges-is retained. Practically it lasts throughout the ephebic stage, and the engonoceran stage is passed through with great rapidity. In this tho renter is flat and bordered by weli-defined elongated tubercles, and consequently there is a quick appearance of the senile stage with elevated conrex rantel between large elongated nomes. It should be noticed that one of the varieties imitates the sutmes of $k$. subjectum in the shape of the saddles and lobes, lont these remain characteristically simple in ontline (Pl. XIX, fig. 11). Fome varieties have bifid saddles and some do not lave them. 'The diviling marginals of the saldles enlarge loy growth when they' ocem, until they often form lobes pratically inseparable fiom others.

Locality: Four and me-laklf miles northeast of Gainesville amb 1) nison, 'Tex.

Age: Upper part of Comanche series, Pam l'aw beals, Walshita gronp. 


\section{Fingonoceras mierdexale (vom Buch).}

Pl. XX, tigs. 6-13.

Ammonites pumbemlix ron Buch, Alhandl. K. Akad. Wiss. zu Berlin, 1st8, pl. 6, figs. :-10.

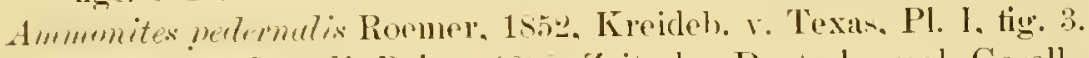

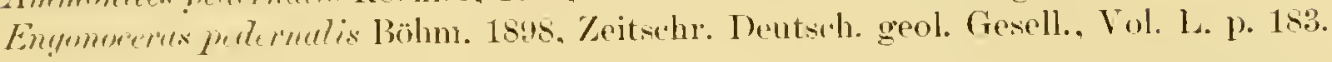

1 have placed this here with a query, hesamse I find it impracticable to identify the roung figured by rom buch with any form known to me. The ventral bobe and saddle and the other parts of the suture might belong to the yomug of a species a grade more complicated than any here lescribed. There is a row of thonghted norles close to the venter in ron Buch's figure, but the presence of such ormanrents is denied in the text, and the nodes are said to be on one side and the to the exposure of the joints of the siphmucle. Roemer states that he hat the originals in hamd when making his description, and that the species was muth larger than that described by him.

Tenmay" mentioned this species as the type of his genus Engonoreras and repeats the nane "pierdenulis" instead of "pedernalis," the mame given by Roemer, and also repeats von Buch's figure of the sutme on Pl. 7 ot Uber Ceratiten.

Tou linch and Nemuary also both describe the principal saddles as bificl, a condition that loes not exist in any specimen of the genns that I lave seen.

Loculity: Texas.

Aye: Fredericksburg group of Comanche series.

Engonoceras pierdenale raliety commene Hyatt.

Pl. XXI, fig. 1.

A fragment in U. S. National Itusemm, No. 8301b, from Bell County, Tex, is slightly crushed in the umbilical region, but has sutures and markings well preserved. At larger end the rolution is 33 by $14 \mathrm{~mm}$, at smaller enrl 24 hy 11 11m.

The venter is flattened and narrow, bordered by small elongated tubercles rather numerous and closely set as in the arlults of this species. There is an inner row of tubercles, harlly perceptible median row, and equally faint fold-like costations on the outer part of the volution, which can be felt better than seen on this cast.

"Amm. 1. IIilsbild. Nordeleutschlands, Palicontogr., Vol. XXVII, 1s8t)-\$1, PP. 1Bs, 141 
The ventral lobe is slightly asymmetrieal to the left, giving rise to andsiderable differences in the first lateral saldles on either side. The first lateral on the right is bitid, the onter arn very brad and bitid, the imer whbdivided asrmmetrically by a rear minute marginal lohe. begond this the inner arm is entire and quite large and phyllifom. There are ten sirdlles and nime bobes on this side All the formes are entire except the innemost, which is slightly biticl The lobes vary fiom trifid to six-pointed. On the left side the first lateral sarldles have the usual bifid form without further subdivisions. All the saddles applear to have entire phylliform outlines, but this may be due to the worn sutures. The first to fourth lobes are slightly digitated, the fifth is faintly trifid, and beyond they are too much worn to show the minute serations.

On the left side the first lateral sadiles lave the nsual bifid form, the onter arm broad, pointed extermally, and with only a slight indentation on the margin. The secomd to seventh lateral saddles are entire and phylliform: the eighth is broad and deeply- bifid, but is apparently only one saddle: the ninth and tenth are entire.

The first to fourth lobes are faintly denticulated, the fifth and sixtl narrow and trifid. The seventh is totally unlike any uther lobe. It seems to be filed by a pointed saddle, the end bifid in one aise.

There is also another specimen from the same locality, a cast with a part of a living chamber preserved. This is about one-lalf of a rolution and in the gerontic stage, the last five sutures overlapping. The preceding sixth or eighth, being in the ephebic stage, do not orerlap. The lobes and saddles are like those of the fragment just described, the sixtl to the eighth sardle on the right side being bifid and the ninth entire. The saddles in ohl age, however, are thatter and the lobes become shorter.

The ormanents are the same as in other specimens, but the renter. becomes broader in proportion to age: tubercles persistent. The living chamber is obvionsly nearly complete and must have been at least one-lialf of a rolution in length.

Three small fragments from locality No. 1554, Seven Knobs, near Glenrose, Tex., have tubereles larger and nore prominent, and althongh the sutures vary they are neal enongh to belong to the same species.

The largest specimeno over one-halt of a volutim is $52 \mathrm{~mm}$. in dianeter. P'robalbly, allowing for compression, this diameter is only $45 \mathrm{~mm}$. The 
living chamber is about one-half of a rolution and is nearly complete. The senter broadens gut, and this specimen seems to be outgrown, judging from the approximation of the last thee septa. The sutures are similar to thase of the preceding, but the serenth saddles are hifid.

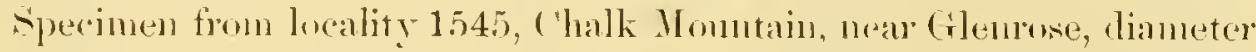
of volution 5o mm., partly estinated, has seventh saddle on the right side biticl: all others extemal to this entire and phylliform, except, of comse, first lateral. This cast shows plainly that what is here comnted as the second lateral is an adventitions saddle derived from division of the first lateral sadclles, and the first lateral lohe is also an adventitions inflection arising from a pimitive maryinal of the first lateral saddle.

I fragment from the Goodland limestone, Choctaw Nation, about 100 miles east of Prestom, 'l'ex., is consideratrly worn, but apparently of this species. The volution is $33 \mathrm{~mm}$. from line of involution to renter and is in gerontic stage, the last six sutures overlapping. The renter is alsu rapidly bromlening, the gerontie tubereles and coste are harger than nsual, and the venter is more asymmetrical or zigzag in outline. There are nine saddles risilde, and the seventh and eighth ane bifid; the outlines of others are entire. The lobes, owing probably to attrition, alre all entire.

A specimen in the United States National Musemm, No. 226i43, from locality No.973, near Cerrogordo, Ark., las a combànation of elaracters which appears to unite serpentimum with pierdenule. The sutures have the broad, short saddles with flat bases, like tlowse of serpentimum from near Gainesville, but the size of specimen, nodes, and aspect ane similan to the typical fonsils of premenale. The surfice is won down somewhat in this cast, and probably these resemblances may be due to this cause. This cast is $91 \mathrm{~mm}$. in whole dianeter'; transverse dianeter estimaterl at $20 \mathrm{~mm}$

A cast in the Insemm of Comparative Zoology from Towash, Hill County, Tex., is 5 ti mus. in diameter; the onter volution is 27 mun, the umblicus 8 mm., and the opposite part of sane volution from line of involution to venter $21 \mathrm{~mm}$. 'This is an ontorown specimen, the last six sutures overlapping those preceeling, while in ephebic stage they are separated by a distinct interval.

There are the wisul lines of tubereles, and the enstae on the outer part if the volution become rery decided, ats in other aged specimens. The vented. is at first narnw, but this becomes much broader at the same the that costat 
increase in size in last part of the outer volution The venter rums from 2 to $7 \mathrm{~mm}$. in width on this one vohtion. The living chamber is complete internally and is somewhat less than one-half of a volution in lengtlı. The sutures resemble those of sperimens describerl above except that there are mily seven saddles, the fifth and sixth very larom and bifid, the seventh entire.

The first to third lobes are very slightly digitated; the rest are entire.

böhn's stmdies of the miginals of the deseriptions of this species have been referred to in the generic description. Whateves doubts of B̈̈lm's rondusions may remain in the mind, it is surely safer to follow such an investigator, who has worked over the original materials, than to indulge in speconlations with regard to the exact meaning of ron Bucli's and Roemer's descriptions and figures, albont which the most opposite opinions might be reasonably entertainet.

\section{Enginsoceras atbjectum n. np. Hyatt.}

Pl. XX1. figs, 2-6: Pl. XXIl, figs. 1-5.

A good cast of this form (No. $43 \mathrm{I}$ in Inseum of Comparative Zoology) is $101 \mathrm{~mm}$. in cliameter, the inner oldest prit of the outer volution being partially destroyed, so that this could not be measured. The living clamber was probably, when perfect, not less than one-half of a volution in lengtlı. The whole dianeter was about $102 \mathrm{~mm}$.; the transverse diameter was decreased so by compression that the measurement near base of living chamber could not be relied on, but this was $18 \mathrm{~mm}$, the rentro-dorsal brealth of side heing at the same place $43 \mathrm{~mm}$. The living chamber having been excavated, it was possible to measure the interior volution in the same line with the largest dimeter given above. 'This was found to be $73 \mathrm{~mm}$., the largest volution being $40 \mathrm{~mm}$., the umbilieus $7 \mathrm{~mm}$., the opposite part of same volution $26 \mathrm{~mm}$. No shell was present on this cast. 'The involution covers up the entire side of inner volution at diameter of $86 \mathrm{~mm}$. This is found in several specimens, but does not appear to be invinable. There are large nodes along the umbilical shoulders, very olscoure nodose folds along the rentral surfaces of lateral zones, and prominent elongated alternating norles along either border of the renter. These last are finer in the ephebic stage than in the gerontic substages At diameter approaching $100 \mathrm{~mm}$. the venter loses the flattened aspect ot 
the ephehie stage, becomes broaler and slightly rounded, but still retains the tubereles and asymmetrical aspect dne to their prominence and alternation. The gremente living chamber is about onc-half of a volution in length wn the rentril side, the dorsil sirle being absent.

'The ealliest suture in type No. 431 at diameter of 26 mm. from line of involution to valuter las eight saldles and seven lobes to the umbilical shomblels. Beyond this ther were not visible. The siddles are narrow and ply yliform or elub shaped; the lobes also are clubbed and have primitive denticulations. First lateral saldle is trifid and inner marginal lobe is digitated. the secomd to fonth entire, fitth to eighth bifid. The rentral lobe is longer than nsmal in this genus, but has the msnal form, divided by entipe hroad siphomal saldle. The firnt, second, and third laterals lave alwut five denticulations nuepually divided, and the fourtl is trifid. Iater in the gerontic stage the second to fonthls sadrlles become either bifid or have more digitations, and the digitations of the lohes increase to seven; the phrlliform asperet also increases.

When the rolution is about 37 nm. in diameter from line of involution to venter, there are apparently about the same number of saddles and lohes, PI. XXI, tim. 5. The lobes have more denticulations and the third sadelles ale also taintly bitid. In another specimen, Pl. XXI, fig. 6, same locality at about the sime age, all the saddles and lobes are shorter and broaler in proportion, but decidedly phylliform, the lobes are more denticulated, the first lateral saddles deeply trifid, the second to fifth saddles entire, the sixtlı to the eiglitl (the last me visible) distinctly bifid.

A cast (No.10755, Boston Society of Natural History) from Bell County, Tex., is $75 \mathrm{~mm}$. in whole dianeter. The entire volution is $39 \mathrm{~mm}$. from venter to line of involution; the umbilicus is $10 \mathrm{~mm}$; the dianeter opposite from line of involution to venter is $27 \mathrm{~mm}$.

This is in the gremutic stage, the last five sutures overlapping. There are ten saddles and nine hoses on the left side. The secoud to the sixth are entire, the seventl to the ninth are bifid, and the tenth is entire. The satdles and lobes lave the elongated pliylliform character of this species.

Locality: Gabriel, Williamson County, 'Tex.

Aye: Comanche series, Washita?

The remakable and highly instructive specimen described below is a cast with an approximate diameter of $55 \mathrm{~mm}$. It was received from Dr. 


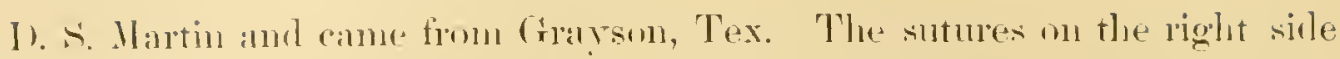

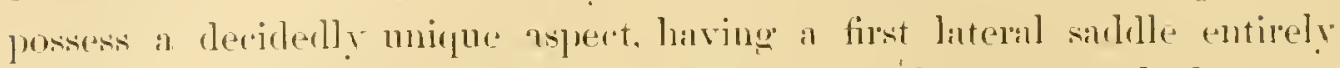

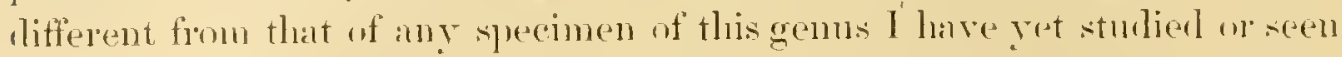
figmed. The whole aspect of these suturesimlicates a now species, whereas the sutures on the other sille, although eomsiderably abraded, are perfect enough in places to show the ordinary form of first latcoral siludle commonly foumd in Metengonoceras. 'The sutures of the right sicle are more like thuse

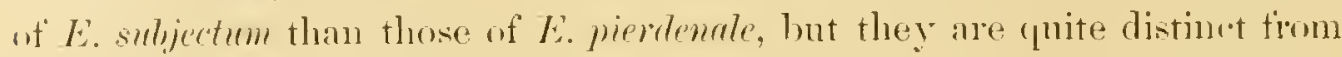
lonth in the aspects of the saddles. On the right sille there are nine saldles and eight lobes. The first lateral saddle is broad and distinetly trifid. The inner arm is broad and las the nsual shape of other suecies, being puinted extermally and rmuning well on to the renter. The central arm is a narow, small maloginal saddle between twa small entive marginal bobes: the inner arm is namover than the outer am and phylliform. The second to the fourth saddle are entire and phylliform, the fifth and remaining saddles lave flatter bases. The fifth is still entire and the remaining waldles also, except the sixtl, which is hourl and bitid. This bifid character can be detecter only on the first part of the onter volution where the dividing hobes are not abmaded, but even this is open to some doubt.

The ventral lobe has the usual outline and is symmetrieal in position; nevertheless the first lateral saddles on the left sirle are quite distinct from those un the right side. 'They have the usual bifid character of specimens of other species, and there is mothing musual in the motlines of the sutures on this side. The seventh and eighth saddles are bifid, and the sixth is entive. The ninth salllle is broarler than on the light side. The conditions of the sutures on this side did not admit of more minute observations. The first to the fourth lobes nu the riglit side were of the nsual form, but rather compely serrated and similar to those of specimens from Bell County, Trex., lescribed above (collection of the Boston society uf Natural History, No. 16,5s). It agreed also with the last in the prominence of the middle line of tublereles.

Lorality: Grayson, 'T+x.

Sinular sutures oeruy in a rast of this species kindly loaned nu by Prot. l. WT. Cragin, and in this the eighth saldles are on the umbilical shoulders and the honal nind reaches to the line of involution: the second to the sixth sidllies are entire; the seventh to the nintl are bifid.

Locelity: 'T'arrant ('onnty, 'T'ex. 
The venter in this species remains consave and his a sharp ridge on eitlere wicle at the ventro-lateral angles, broken into wares by equally acute but elongaterl, norles on the cants. Shells were not present. In old age these moles persist, but the ridges dinappear and the renter becomes flattemerl, and finally convex.

I cast from Denison, Tex, Duck Creek beds, Lnited States Geological survey, has rery different sutures and is also somewhat different in general aspect. The living chamber is complete in the immer borders and is considerably less tlan one-fonrth of a rolution in length. It is in the gerontic stage: the inner tubercles are large, and the outer ones, terminating short, fold-like eostex, are also very large. The venter is completely rounded and much zigzagged in correlation with the large tuberenlose alternating folds and moles of the costa.

The whole diameter is !2 mm.; the onter rolution. which is somewhat reduced by gerontic contraction, is $42 \mathrm{~mm}$.; the umbilicus is $14 \mathrm{~mm}$., this being enlargerl in proportion to reduction of gerontic part of volution, and opposite from line of involution to venter is $36 \mathrm{~mm}$. The saddles are quite distinct from those of specinens described above, but have the same distinetly phylliform aspeet: the hobes are more alike and with sinilar serrations. There are nine saddles on the right side. The first lateral has the same deeply bitid form as in specimens of this species. The secomel to seventh have rounded leaf-like bases; the eighth is still phylliform. but broadens out and is lificl: the ninth is entire. The first lateral lobe is evidently rery slightly divided, but the second to the fitth are more richly denticulated than the sixth and seventh and are faintly tritid (?); the eighth is perlaps entire, but not plainly seen. The living chamber is shorter in this specimen than in any other example of this speries and the nodes are more like those of serpentimum, while the sutures agree better with those of subjectum.

The prineipal listinction between this species and its allies of the same genn.: lies in the more elongated phylliform sudelles and lobes.

Lingonoceran gibbosum 11. sp. Hyatt.

Pl. XX11, figs. ti-10: Pl. XXI11. tigs. 1-ti.

The best example of this species is an entire cast in my collection from Crok Comnty, Tex. This has the median line of noles allong the central line of the lateral surface, the outer distinct and short and no prerceptible 
conta between these. This cast, the trpe of the species, shows no gerontic characters at the liameter of $93.5 \mathrm{~mm}$. The greatest transerse dianeter is at the umbilieal shoulders and is $25 \mathrm{~mm}$., the breadth of the side at the same point being $50 \mathrm{~mm}$. The sutures are quite different from those specimens described below, but there is the same general character: the second lateral saddle and the fifth are bifid; the sixth is mequally trifid; the seventh is a componnd sadale with two bifid arms; the eiglith to the tenth are entire or Hat. The more gibbous sides, the prolonger stage during which the nodes persist and are sharply defined, and the large number of bifid saddles characterize this species. 'The sutures are the most complex, with exception of Eng. roemeri, of any that lave been so far descibed in the genus.

The largest fragment in the National DInsemm is about three-eighths of a volution. Widest dianeter is $91 \mathrm{~mm}$.: the distance firom line of involution to venter is $50 \mathrm{~mm}$. at the larger end and $38 \mathrm{~mm}$. at the smaller end; and the transverse diameters are $20 \mathrm{~mm}$. and $\mathrm{I} f \mathrm{~mm}$., respectively. This speeinen was probably entirely mompressed. 'The venter is narrow and flat and the sides are slightly gilbbous and highly convergent outside of the middle row of obscure nodes. Between these and the umbilical shoulders, however, al flattened zone is developed, which may even slightly slope inward The nsual row of nodes is present on the umbilieal shoulders, and also the rows of alternating tubereles on each side of the venter. The latter are sharp and well formed, elongated, and suffieiently numerous to give a decidedly zlgzag aspect to the nalrow venter.

The venter is flat in the early part of the neanic stage and nuch broader in proportion to the volution than in later stages, as it is in most species of this gemus. The rolution has more flattened sides at this age, and the involution begins to cover np the rolutions to the umbilical shoulders even at this early stage.

The sutures are well separated, as in other shells of this genns, and are very remarkable. There are on the right side ten lateral lobes and eleven saddles at the larger end of this fragment and the same number at the smaller end. These are more difficult to count and quite different on the left side. The rental lobe is stmmetrieal and of the typical form.

On the right side the first lateral saddle is bifid, the outer arm short, broad, and spreading, the imer also broader than in most other forms; the outer is subdivided by a minute marginal or slightly and unequally 
bifid: the inner arm is slightly trifid in nearly all the sutures, and this becomes more apparent in the older sutures. The lateral saddles ar. broadly phylliform. The second laterals are obscurely and equally bifid in all the sutures: the third shows a faint tendency to become bifid only in the older sutures: the fourth seems to have a similar tendener, hut this does not become denonstrable, and it must be described as narrower at the base and entire. 'The fifth is bifid in the younger sutmes observed, and hecomes more distinctly hifid with age; the sixth is marowel and entire; the seventh is equally bifid; the eighth is also equally bifid, but the inner am is unequally subdivided by a minute marginal; the ninth is also equally bifid, and each am is also hifil with a minute marginal lobe: in some sutures both are unequally divided and in others the onter is stmmetrical, the imer asrmmetrical; the tenth is small and entire, and the deventh is very broal and is subdivided by a minute marginal lobe introduced on this volution, and the miter arm shows a tendency to broaden and become bifid in the older parts of the same. The saddles are phylliform but rather short and stumpy from second to sixth, then they becone very hroad and less phylliform; the lobes have the usual narrow bases hetween the expanded bases of the saddles and spread out apicad between the phylliform saddles. These are all apparently mequally subdivided, and the digitations and serrations are somewhat more numerons in the second to the fifth laterals than in most other species. The first and sixth are simply trifid, the seventh and eighth bifid, the ninth and tenth entire.

On the left side the first lateral saddles lave a narower outer am, divided by a deeper marginal lohe, and the imner an is not so broad and shows only a faint tendency to become bifirl. The second lateral is more distinetly hut mequally bitid: the thim show a faint tendency to a trifid undulation; the fourth is entire: the fifth is faintly hificl: the sixth is distinctly but asymmetrically bifid; the secenth is equally and deeply bifid: the eighth is very broad and also deeply bifid, the outer arm has the margin faintly moluated buto four nearly equal manginal serrations, the imer arm is asymmetrically bifid; the ninth is also nosymmetrically divided, the outer part on arm is very boad, rather rounded basally and undulated into three minute serrations on the margin, the inner arm is a minute saddle; the tenth saddle is like that of the right side, hut faintly bifid in the first sutures seen; the eleventh saddle is narrower than on the right side and 


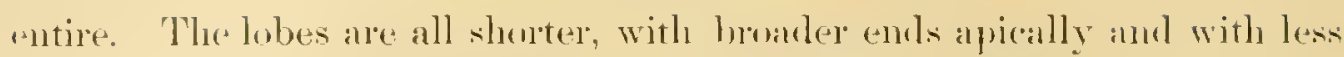
(omplex digitations than on the right side.

One small specimen, a cast from locality 14!y-2, 15 miles west of Denison, 'Tex., has a cliameter of $+6 \mathrm{~mm}$, outer pant of volntion, $23 \mathrm{~mm}$;

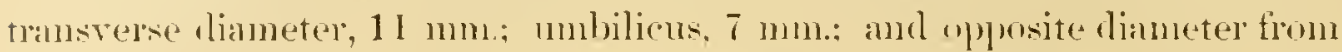
line of involution to renter, $16 \mathrm{~mm}$.; transverse dianeter, $7.5 \mathrm{~mm}$. This has the same shape of renter and genelal aspect. The nodes of the inner line are present as elongated costae, which are most prominent at the umbilical shoulders and much incliner wad. Very ubscure nodes conld be felt over the more perfect surface of the cast alomg the centran lateral area. The cast was too inperfect along the venter to observe nodes, but at the beginning of this volution on a small bit of the shell of the venter exposed by excarition there were smooth ridges at the vento-lateral angles, and the venter was concave.

The sutures in this are corveled together munsually elose for shells of this gemus, the imer lobes and saddles overlapping slightly, beginning with the third lobes and fourtl sadclles. It is probably a dwarted form of this species, since in the earlier part of same volution the sutmes are well separated, as in other forms.

The rentral lobes ane obliterated, but sufficient of the first lateral saddles remain to show that fley were mequally hitid and that the outer arm was alko bifid, the inner am entive and quite large. The second to fourth saddles on the left side were broul and entire, the fifth to serenth srmmetrically and deeply bifid, the eighth very hroal and nnequally bitid, the onter arm faintly bifil, the ninth alone entire. There is considerable variatim on the right side, the sixth sarlolle is not deeply bitid, the seventh is megually bifiul, the eighth is like that of the left side, but the bifidity of the margin of the outer am is more promonnced. The rentral lobe is symmetrical, but so monch worn rown that no observations were pranticable exrept at two of the sutures, when it seemed to have the nsmal greneric form. The living rlamber was not present in either of the above-described specinters.

A small cast from Bell Comnty, Tex., No.8301a, about a fourtl of a volution, is $23 \mathrm{~mm}$. in dianleter from line of involution to venter, transverse dianeter 14 mm., two lines of tubercles and median line of elevations well lefined, venter distinctiy concave. The sutures appear to have more 
resemblances to those of the older stages of this species than to any others. The rentral lobe is namow and slightly asymmetrical to the left, but the first lateral saddles on both sides are alike. They are both bifid, the outer arm is entire but is blunter than usual on the renter. The first to sixth saddles are otherwise like those of the specimen described above; the seventh to ninth saddles, seen only on the left side, are symmetrically bifid, the tentlı is entire. This bifidity of the internal saddles agrees with those of uddeni, but the aspect of the rolution and the general form of the saddles and lobes agree better with those of this species.

Locality: Cook Comnty, Tex., 15 miles sonthwest of Gainesville and 15 miles west of Denison.

Age: Fredericksburg division of Comanche series.

\section{Engonoceras stolleyi Böhm.}

Pl. XXIll, tigs. 7-4: PI. XXIV, figs. 1-5.

Engrmaceras stulleyi Bölm, 15!s. Zeitschr. Dentsch. geol. Gesell., Vol. L, pl. 5.

This species has the flattened venter, becoming alternately nodose and zigzag in old age, as is cluaracteristic of this genns. It is not distinguishable from $E$. pierdenule except in the sutures. The lateral saddles and lobes are smaller than in any otler species of this genus, and the first lateral saddles are apt to have the inner marginal sadilles tongne-shaped. This peculiarity is noticeable in Bülmin's figme and in the large fossil (Pl. XXIV, fig. 5$)$.

Age: Fredericksburg gronp [?], Comanche series, Lower Cretacenus.

Lingovoceras complicatum il. sp. IIyatt.

Pl. XXI. figs. 6-8.

This is founded upon a ast from neal Anstin, 'Tex. The whole dianceter, partly estimated, is 73 mm., the outer volution is 39 mm., the umbilicus 9 $11 \mathrm{~m}$., the volution opposite (estimated) $25 \mathrm{~mm}$. By the cast alone this species conld not be separaterl fiom Engonoceres giblosum, but the sutures are nevertheless entirely diffirent. A better preserved specimen might, howevar, show some external characteristio distinctions. There are fomrteen sutures visible on the onter volution; then comes a gap between 
them and those on the first quarter of the same volution. The entire fomteen overlap, but the tenth, eleventh, and twelfth are nearer together than any other's. The ephebic sutures on the first quarter of this same molution are well separated. There are eleven slender saddles am ten stender lobes on the left side. The furst lateral is narrower than in any other species and bifiel, with tongene-shaperl entire arms; the second and third laterals are also entive and linguifoms the fourth to the ninth are phylliform and bifid; the tenth could not be seen; the aleventh was entire.

The rentral lobe is narower, deeper in proportion than in other species. There is a smaller and contorted cast from Benbrok, Tex., with similar sutures so far as the bifidity of some of the prineipal sardelles is concerned. It is rery likely a variety of this species. The matkings, so far as can be determined, are similar. The living chamber is about one-half of a volution, the last sutures overlap, and the shell was evidently in the gerontic stage. The third lateral sardles were bifid, the fouth was entire, the fifth to ninth were more or less phylliform and bifid, and beyond this nonce were visible.

it differs from I'rotengonoceras emaymatum (Cragin) in luaving pronounced lines of tubercles along the ventro-lateral angles and its greater number of lobes and saddles, judging from the descriptions of that species. The chatacteristics of the venter and the size as given by him indicate a larger species, with venter more like that of I'roten. gabli. A small specinen, a cast, from 15 miles west of Denison, Tex., has a diameter. of $46 \mathrm{~mm}$; onter part of rolution is $23 \mathrm{~mm}$.: transverse diameter, $11 \mathrm{~mm}$; mubilicus, $7 \mathrm{nmm}$., and opposite diameter from line of involution to venter, 16 mun; transverse dianter, $7.5 \mathrm{~mm}$. This has same slape of venter and general aspect. The nodes of the imer line are present as elongated coster, most prominent at the mubilical shoulders and much inclined orad. These disappear as they pass the centran lateral surface. Torles condd not be seen mor felt over the perfect surface of the cast, and nome were visible at the legiming of this volution on a small bit of the shell of the venter exposed by excaration.

The sutures in this specinen are crowded together musually close for shells of this gemus, the inner lobes and sarllles overlapping slightly, begrinning with the third lobes and fourtl sardelles. It is probably " 
dwarfer form of this species, since in the easlier parts of same rolution the sutures are well separated, as in other forms.

The rentral lobes are obliterated, but sufficient of the first lateral saddles remain to sluw that they were equally hitid and that the outer arm was also bifid the imer arm entire and quite large. The second to fourth saddles were, on the left side, hoad and entive, the fifth to serenth symmetrically and deeply hifid.

Locality: Near Austin and Benbrook, lex.

Age: Frederickshurg group, Comanche series.

$$
\text { Engonoceras emarginatum ('mgin)." }
$$

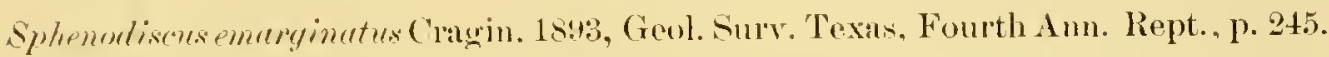

Areording to Cragin's description, this species has the concave venter until il late stage, but has the tubercles and sutures of this genus.

\section{Fingonoceras roemeri (Cragii).}

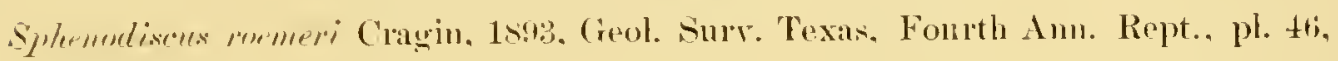
fig. 1.

Cragin describes this shell as having "venter nurowly truneate, the rentro-lateral angle at first shap, hecoming on the body-chamber subtuberculate-sinnous." This and the general ontlines of the sutures, if they are suppused to be deprived of their marginal saddles, as they must have been in the young of this shell before these were dereloped, has caused me to refer the species provisionally to this genus The sutures are, however, obviously more complex as figured by Cragin than in any other known form of Engonoceras. The principal saddles are all bifid, trifid, or quadrifid, and the smaller saddles inside of what appears to be the fourth saddles are mostly bifid.

Ir. Stanton has written as follows regarling this form:

According to Cragin, this is from the "alternating beds" - that is, the Trinity division-not Fredericksbng, as given in your MIS. If this be true (and MH. Tatf", -tratigraphic data look all right). the form is probably the oldest one of this gromp that we have from the Comanche serion.

Lorulity: Iredell, Bosque Comuty, Tex.

Age: Comanche series, Glemose beds.

"See 1. 157, where this species is doubtiully referred to Protengunceras.-T. II. S. YON XLIV- $0: 3-12$ 
NEULOBITES Fischer.

The sutures of this gemm have, perhalps, simpler outlines than those of an other Cretacens ammonoid, and have heen supposed to place the gemos somewhere near Tissotin. 'They, however, difler decisivaly from

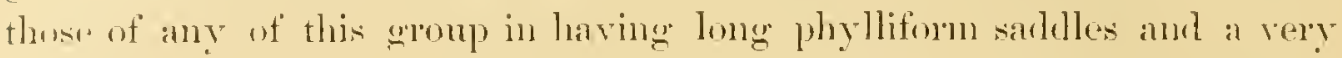
peculiar ventral lohe. The form, wromentation, and old age of the species from Thusia, described by l'arom, womd place it in the gems. Placenticeras, if nos sutures were risible. Jut the sutmes and monentation agree witl those of Eugomeres, and show that it is probably a nember of the same fanily. C'hoffat's resenches have placed this conchsion on a secure fonting:

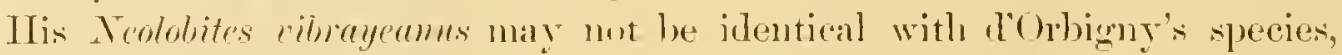
hut it is smely a close ally, and he gives the sutures in full, and these show the ventral lobes and siphonal saddles and first laterals to be similan to. thase of Enyonoreras. If the young, when seen, pore to have a similan development, the evirtence will be complete.

\section{Neolobiteg vibrayeanus (D'Orbigny).}

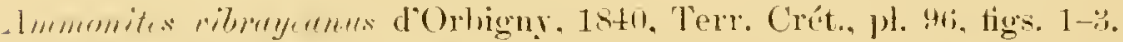

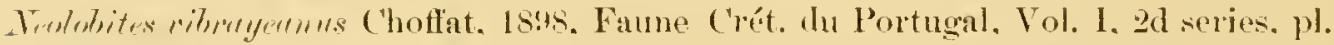
5. figs. 2.5 (not figs. 3, t.)

This species as fignrent by d'Orbigny has led to great confusion, wwing perhaps to the absenese of a sufficient representation of the details. Choffat las figured a species from Portugal which, if not identical, is probably similar to d'Orbigny's species. All the rharacters coincide with the position here given to this form. A number of species are confused under this name, but the data given are not sufficient to separate them.

Locality: France and Portugal.

Aye: renomanian.

\section{Neolobites choffite 11. sp. Hyatt.}

l'. XXV, figs. 1-

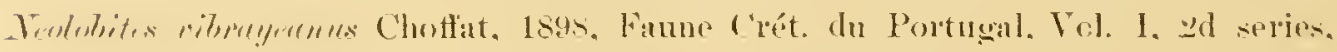
pl. 5. tign. 3. 4 (not tigs. …5.)

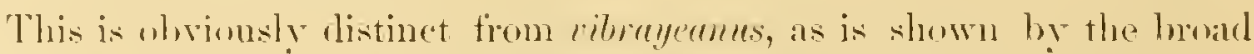
venter and histinet sutures as well as the more gibbus form.

Locality: l'ortugal.

Igr: C'enomanian. 
Nélorites peroxi n. sp. Hyatt.

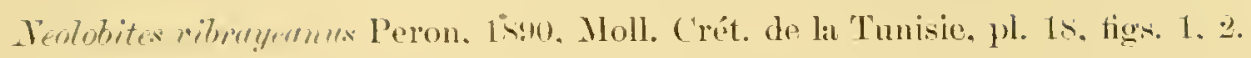

A highly compressed shell with marmer flat venter borlered on either side by a line of small, closely set tubercles with numerous costur on the Hat sides, focussed intu a very fow large nodes near the mubilical shoulder. The involution is almost if not quite complete. 'The nubilicus is not figured in l'eron's figme, but it must lave heon very small. In extreme age these nodes recede finther from their first position, the rentro-lateral lines of small tubereles disappear and the renter becomes elevated and is represented in the last stage as subacute. There are five or six lateral saddles in this species, according to Peron's drawing. Prron ronsidered this form to be distinct, but did not describe it as a new species.

Loculity: North Africa.

Aye: Cenomanian.

\section{MFTENGONOCERAS 11. gen. Hyatt.}

The shell is compressed as in Engonoceres and the involution corers the greater part of the sides of the internal volutions. l3road, fold-like sigmoidal costa are present in some species and faint tubercles have been observed in rare casces on casts. To well-preserved shelk have been so far seen nor described The renter in the neanir stage is comparatively broad and slightly concave; in the ephebic stage it becomes very narrow, but retains a linear concavity; in the full ephebic stage it becones acute, and in gerontic stage subacute and then rounded. The sutules do not differ materially from those of Enyonoceres; the distinction, so fan as known, lies in the development of the venter and absence of nodes. The young were similar to the adults of I'rotengonoceras, as me those of other genera. The principal or outer lateral lobes and saddles are short, the lobes narow and entire between the entire and more or less rounded, often phylliform bases of the principal saddles. The apical ends of the lobes are lenticulated, but the marginals are entire, pointed, and the saddles blunter but also entire. The smaller inside of the principal outer saddles are often bifid. The ventral lobe is narrow orally, rery short and broal apically, with two contire arms, and is divided by a depressed but nore or liss subarnte entire siphonal saddle. The first lateral saddles in most species are broad and 
bificl, the onter :uns mone on less arute at the onter angles of the bases, and the imner anm narower and tongue like. One of the marked characters of this genus is the absence of differentiation between the parts of the suture at later stages of growth. The principal lateral saddles and lobes can not in numy specimens be distinguished fiom the so-called auxiliary laterals, and I lave not attenuted to do this in my descriptions. In some specimens, on the other liand, espectally young ones, there seem to be plainly only three principal lateral saddles on lohes, but in others there seem to be fon or even five. 'The metaneanic sulstage in one species showed the pumary division of the prinitive first lateral sadelle into three, and in several specinens in a late neanic substage it seened obvious that this subdivision was maintained and that the first lateral of the derivative or principal series became bifid late in the life of the shell. First lateral saddles are therefore morphologically double, even when they are so fully divided that they have to be considered as two saddles, as in Metengonoceras dumbli. In most species there is no difficulty in seeing this, but in about all of then the line botween the three principal laterak and the aniliaries can not be drawn, nor between the princilval lobes and the auxiliaries. Heve, however, as in Engonoceras, there are but three principal laterals, if the first lateral is properly defined as double or bifid.

The subacute venters of the species in this genus have learl to confusion with shlenodiscus and its allies. The ontogeny of the latter separates the two generically, but the latter might be considered an accelerated form of the same family, as stated abore in the description of the family, but for the sutural characters which show that Sphenodiscus helongs in the Placenticeran stivek.

METENGONOCERAS INSCRIPTUM 11 . sp. Hyatt.

Pl. XXV. tigs. i-4: Pl. XXVI, tigs. 1-t.

One entire cast is $80 \mathrm{~mm}$. in dianeter. The diameter from line of incolution to renter is $42 \mathrm{~mm}$. at largest part, the transverse being $16 \mathrm{~mm}$. Both measurements are a trifle short of what they would be in a more perfect cast. Opposite this the same diameter is $29 \mathrm{~mm}$. withont shell, the umbiliens being $9 \mathrm{~mm}$.

A fragnent somewhat younger from same levality was not compresied so as to destroy the shape. This had the same form, but was not so coneave near the umbilicus and had no tolds. 'The volutions were flat on the 
venter in the nemic: stage, and were obvinusly similar to I'rotengonocers in their yommg. The smaller fragment, nearly one-half of a rolution, with center party jeserved, is $52 \mathrm{~mm}$. in dimmeter, and the venter is worn, but in places where sutures are perfect the venter is narowly romuled. In the largest cast, at about the same age, I was able to demonstrate hy excavation that the shell, although very narrow, was thick and distinctly concare on the venter. 'There were apparently no large mbercles at any stage. The tirst lateral saddles in the small fragment, at a diameter of over $52 \mathrm{~mm}$, were broad, very short, and had the imner angle fimished with a large marginal lobe and saddle.

The second to fiftl saddles on the right side, and the second to sixtl on the left side, are entire, the sixth on the right and seventh on the left being the first of the bifid sadrlles. 'The other saddles are all bifid, except, perhaps, the innermost pair, but this was not seen.

The lobes are too much worn down to show their minute digitations except in a general way. 'The ventral lobe and minute median saddle are present and the first lateral saddles are narow. On the youngest and least-worn part of the larger specinen on the right side, the first lateral saddles show slight marinal lobes and saddles at each of the innor angles, but there are minute narginal lobes on the onter parts of these saddles. Several of them show this division, and one is distinctly tritid. On the older parts of the same sperimen they are, lowerer, distinctly entire as in the other fromment, and this I think is the nommal character. 'The wearing' to which it had been exposed cansed ne at first to count three entrie sardles on the left sirle and four on the older parts of the same volution. It is obvious, however, that it is the sixth saddles that are bificl on botle sides. The remaning saddles are bitid to the line of involution. In both of these specimens there are ten saddles and nime lobes, but there was probably in each a lobe on the line of involution. 'Tlye youngest sutures were about 5 inm. distant, but the last nine lost distance rapidly and were more or less irregular, and in the last four the second lateral suddles overlapped slighty the second lateral lobes.

The larger cast has threc much-worn fragments of the attached valves of an ostrean on the right side, which hald evidently been exposed above the calcareous mul while in the same rondition as at present, namely, a distorted fossil cast, and the ostreans erew upon the surface of the cast itself. That the rast had already suffered from attrition and compression 
was shwon by the ancurate fitting of the ostrean shells into the irregnlarities of the broken and worn surface. $A$ few other lower ralves were removed to study the sutures, but in no "ase conld I find any remnants of the shell of Engonorevas between the bases of attaclument of the lower salves of the ostrean and the surface of the cast. 'The specimens still left upon the cant show these facts also. The smaller specinien was much smoother and cleam.

1 much-rlistorted fragnent from another locality, 9 miles from Austin in Beecares rond, of what seemed to be the gerontic stage of this speries is $8.5 \mathrm{~mm}$. firm line of involution to renter and this is very nealr to the actual diameter in a perfect cast. The greatest transverse diameter is 35 mm. and is somewhat greater than in a perfert cast of the sime age. This specinch, howerer, has the sutures well shown on the right side, and the differences, with one exception given below, when comparenl with the first specimen deseribed, can be accounted for as probalbly due to greater age. The saldles and lobes are all murl nearer tugether, the orerlapping beginning between the third saddle and second lobe. "The curvature was the same as in the smaller speciment.

The tenth saddle is the first hifid one and the remainder are bitid and near the umbilicus become very broar.

This difference can not be accounted for by supposing that the seventh and eightl saddles have becone completely divided by the advance in development of the marginal lubes, thus adding two saddles to the series, but indicates some original variation in this shell.

The ventral lobe could not be defined and the condition of the other lobes only enabled an observer to see that they were digitated and near the umbilicus they were too much wom to say even this nutch. The lengthening out of the saddles by growth does not decrease the phylliform aspect of the bases and the lobes beene narrower and longer withont apparently altering much in general outline.

Loculity: 'Twrelve miles northeast of Decatur, Tex.

Age: Fredericksurg group, Comanche series, Lower Cretaceous.

\section{MLETENGUNOCERAS INSCRIPTCM VAR.?}

This is a fragrnent of a rolution of a large specimen, showing only a part of me side. It is, howerer, interesting, for the clanacteristios of the lobes and satdles given on Pl. XXV, fig. 8, show rarbations in the forms of these. A specimen from west of Walnut springs, Tex., kindly loaned me 
by l'rofessor Cragin, shows the subacute venter. 'The eighth saldhles are bifid in this fragment and there are only ten wn the right side, with large mequally bifid first laterals as in linge fragment described abore.

Locality: Fifteen miles west of Denison, Tex. lacality 1492, L. S. Geological Surrey.

Age: Frederickshurg group of Comanche series.

One fragment is $5.5 \mathrm{~mm}$. from line of involution to venter without the shell. The first lateral saddle is deeply hitid, and, comnting this as one, there are only five entire sarldles, some of which, probably owing to wear, appear to show a faint tendency to beeome hifid. The sixtl to the nintl saddles are distinctly bifid; the tenth is a very broad saddle with three minute marginal lobes, and thw alerenth is another broasl saddle which is entire to the line of involution. (On the opposite or right sirle the broad tenth sarkle is divider into two hifid sadulles, so that there are obviously twelve on that side.

Lorality: Cow Greek, Thavis Comnty, Tex. No. 19105, U. S. National IIseum.

\section{MeTExgonoceras ambigutu 11. sp. Hyatt.}

Pl. XXVI. figs. $5-7$.

One nearly entire cast of this form is $79 \mathrm{~mm}$. in diameter, the last rolution $44 \mathrm{~mm}$. from line of involntion to venter, the mubilicus 6 nm., and the opposite part of volution $29 \mathrm{~mm}$. The greatest transverse diameter through medinn surface is $17 \mathrm{~mm}$. and is somewhat less than in a perfect specinen.

The sutures have smaller saddles than at the same age in $M$. insriptum, are also less distant throughout, become still more approximate in later stages, and are straighter. There are thirty septa in this specimen to twentyfour in inscriptrm at same diancter. The sixth saddles were bificl on both sirles.

Fold-like costre along the inner part of the volution ane plainly visible and there are sinall noles along the ventro-lateral angles, the venter being here fantly simuous. The venter was much eroder, but in two places it slowed a narowly rounded area and on the enc of this volution is subacute. lixcaration was nut very successful and I could only demonstrate that the renter was extremely narow in the ephebic stage and perhalps not distinct from that of Eny. inscriptum at the same age. 
This atat was considembly wom. The right side was free of encrusting ostreans; on the opposite (left) side there were a few, some of which were removed. To shell was fomd lotween these and the cast. They had evidently grown mpon this rast and not mpon a living an dearl shell. 'This ran also be seen by stulying the remaining shells, one complete lower valve and part of another.

Lorality: Nine miles from Austin, Tex., m the Beecaves road.

Aye: Comanche Peak limestone, Fredericksburegroup of Comanche series, Lower Cretaceous.

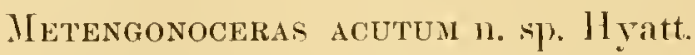

Pl. XXVI, fig. 8; Pl. XXVII, figs. 1, ‥

The type specinen of this species in Boll collection in the Musem of Comparative Zoology is a fragment, lut this slows the whole dianeter to lave been approximately $100 \mathrm{~mm}$. The outer volution from line of involution to venter is $54 \mathrm{~mm}$, the umbilicus $5 \mathrm{~mm}$, and the same volution opposite must have been about 40 to $41 \mathrm{~mm}$.

The form is much compressed and involute, with more acute reuter than in $M$. inscrintum. The mmbilical shoulilers also in this species are more prominent and entire, and short but distinct, brod, fold-like costre are present near the umbilical shoulders, but do not cross them. There are no tubercles on the fragments observer.

The marginal lobes of the first lateral saddles on both sides are narmow and divided by a mimute marginal saddle or bificl. The first laterals are unsymmetrically trifid, the second to the fourth are symmetrical and quadrifil, the fifth is of the same type but not regularly divided. All of these are very narow at the bases between the expanded bases of the sadrlles and spreal cut apead into the maginal divisions. "The sixth lobe is narrow and hitid, with a small marginal sarldle, and the seventh similar, but with a langer tongue-like marginal saldle, and the minor lobes on either sile ont this ane also subdivided $m$ bifid. The eighth and ninth are distinctly lut rely faintly trifid, and much longer than the narow marginal lobes describer above as dividing the boad satelles of this part, which are fandy hitid. The tentl lolse was visible but not distinct enough for lescription.

buth specinens wore too much crushed in the central parts to give any aceurate data for the description of the younger stages. Nerertheles: 
there are strong indications that the venter becane acute in an early ephebic substage.

The matrix of these specimens is a red, alphrently caleareous, day stone, and indicates a listinct formation from that containing the species of Placenticerus cited from the same locality and also in the Boll collection in the Mluseum of Comparative Zoology. They have remmants of the nacreous layer and one has the shell still left in the umbilicus. 'The interior is so much crushed together that it is impossible to say that the venter was or was not concave in the internal volutions. Certainly, so far as the cast goes, the outer volntion was unguestionably subacute.

Three fragnents in Cragin's collection from the Grayson marl, onehalf to three-fourths mile southeast of the Union Station, at Denison, Tex., have the phylloidal saddles and long complex lobes of this species and also subacute renters. "The last rolution of one of these fragments reaches ventro-dorsal dianeter of $60 \mathrm{~mm}$. while still septate, and has a transverse diancter of $24 \mathrm{~mm}$. The sutures, however, are too much abraded for efficient observation.

The peculiar first lateral saddles of this species, the extremely phylliform saddles, narrow lobes with spreading and digitate extremities, and straightened sutures, separate this fiom $M$. inscriptum. 'The larger size of the lobes and saldles mables one, as well as the more persistent acuteness of the venter in the gerontic stage, to distinguish it from $M$. rlumbli.

Mr. Stanton has written as follows with reference to this fossil: "I think this is certainly from the Upper Cretaceous and pobably fiom the Eagle Ford shales, like the other specimens with the same locality label. such brownish-red concretions are common in weathered portions of the Eagle Ford shales." Tex.

Loculity: Whn Fork and West Fork (Horton's mill), l)allas County, Age: Probably Eachle Ford shales, Coloracto group, Lpper Cretaceous.

\section{Meteygojocekas dumbla (Cagin.)}

Pl. XXVII, figm. $3-14$.

Sphenodisces dmmbli (ragin (pars), 1s!s. Geol. Surr. Texas, Fourth Anu. Rept. p. 243,0$\} .44$.

A superb specimen in collection Lnited States Geological Survey, diameter 94 mm., althongh in three pieces and with nepionic stage and part 
of outer volution alsent, is otherwise perfect and shows many exential fiacts with regand to the afthintios of this genus. The last latf of onter volution or greater part of living elsanber is in the gerontic stage. This shows that the living vlamber was at least one halt of a volution in length. Cragin, who had this cast in hand as part of his materials, describes his specimens as leing "very sharp in the gonng [my adult], becoming ohtuse alomg the londychamber of arult [my old age] specinens." The well preserverl pirt of the gerontic renter in this cast is $23 \mathrm{~mm}$. long and for a few millinuters is romded, with two alnost impereptible ridges on the rentm-lateral andestes, then a hollow reeurs as if the shell had been injumed, and this is contimned to the end of the fragment by a rery faint chamel hordered by faint ridges.

The romuge in the nepionic stage has the nsmal mouded volution: the paraneanic substage was eompressed with flat sides, deep involution, and broad concave venter, witl entire, acute ridges on the burders. This stage is, in otlee words, like the epllebic stage of Protengonoreres, as his been alrealy stated from examination of less perfect speemens. This substage was introduced pradually by the intervention of a metaneanir substage having a hehnet-shaped section with a flattened renter and an ananeanic substage with transitional characters between this and the nepionic rounded volution, but not having the flattened zone on the renter. In the anephebic substage the eompression and flattening continues to increase, the infolution remains constant, and a very narow chamel still persists on the venter.

In the full ephebic condition this disappears and the renter becomes acute. In the paraphlubic substage the renter is subaente, the sides a trifle more convex, and rolution somewhat broader in proportion to the ventro-dorsal diameters, but these changes are slow until in extreme age, the paragerontic substage, when, as stated above, the vanter becones roumled. I have frequantly alluded to the reinstatement hy degeneration at the end of a revele or in the adult of aharacters analogms to those of younger stages. In this specinen the rounded renter of the paragerontic substage has a faint eondavity, and this, after what seems to have been some injury to the edge of the renter, becomes converted, as drscribed above, into a faint rhannel with ridges on the nuter borders. There are no marks of tuborles, nor coster, nor folks at any stage so far as these contl be seen. 
The sutures have short broal saddles with narrow lobes, digitated only at the apical enrk, and while the saddles remain about the same, the lobes increase somewhat in the number of their digitations and in length with age. They are quite different on the right and left sides. The siphunele is eccentric to the right, and ventral lobe follows this organ, hut there is no rew marked difference between the tirst lateral saddles in conserquence of this.

On the right side the first lateral has two branches so deeply- divided by a bifid marginal lobe that it is really split into two distinet entire saddles, but these are more widely separated than in Meteny. acutum, and are more nearly equal in size and aspect. Comuting these as two saddles, there are thirteen saddles-ten narow, entire, and phyllifom, and three broad and bifid, the eleventl rery deeply bifin, and the twelfth and thirteenth sucessively lesis deeply divided. The first and second lobes are bificl, the third to sixth bificl, but with four to eight aligitations: the seventh to tenth simply bifid; the eleventh and twolfth, especially the eleventl, are divided by longer tongue-shaped saddles.

On the left sille the lifferences are as follows: The ninth to eleventh saddles are hroal and hifid, the twelfth is broal and entire, the thirteenth is rery broad and has a sinuous base, and inside of this a very minute lobe shows that there is a small fomteenth saddle. The eighth to the tenth lobes are simply bificl, the eleventh is mequally hifid, lut las nor long tongue-shaped matrinal saddle; the twelfth is entire, and there is an excessirely minute marginal thirtechtl, as stated alwere.

In the atult stage from the fifth saddles inward on both sides the sutures overlap slightly and the ontlines are easily separable, but in the last five sutures this overlappling spreats to the third saddles and lobes and the outlines are more compressed. 'This is accompanied by a slortening up of the saddles and lobes and a corresponding retum of the younger proportions and aspeect.

In the metameanic substage the primitive first lateral is divided into three low broad sinddles by simple indented narginal lobes, and the magnosellarian saddles are also divided, hut the number of these was not aseertained. There were, however, mly a few of thess.

Loculity: Four miles east of Whitesbon, Tex.

Age: Latgle Ford shales, Colorado group, Lpper ( retaceons. 


\section{PLACENTICERATID $Æ$ Hyatt.}

The yommen ame similar to the adults of Fugonoceratidae, having concave venters bordered nsually by continmous ridges with complesserl volutions, the lateral zones converging outwardly. In later stages of genera the venters are either concave, flat, or rommled, but there is no true keel mesent, although the venter may become acute in some species at a late stage of growth. The volutions in the carlier stages sulsequent to the nepionic are apt to be more or less compressed, the venters assuming early the charaters deseribed above, any further sharpening of the venter occurling in later stages. The principal lateral saddles are, so fas as known, bifid in the young and show in most gromps a tendency to become more or less trifid in later stages. The multiplication of inflections of the suture lines jucreases with the involution of the whorls by growth and they become very numerous in some genera.

\section{PIACENTICERAS Meek.}

The species of this gems conld be readily distinguished if it were not for the great range of form in the gremtic stage, which occurs in dwarfed as well as in large specimens, and is comtimully mistaken for the ephebic staige.

Tho noanic shell is smooth, compressed, with at first a Hat and then a concave venter bordered by smootl, entire ridges on the shell and on the casts, but las a stonter volution tlan later stages. It is, in other words, like the ephebic stage of Protengonoceras in extemal chanacters, lunt the sutmes are of the I'lacenticeran type. Subsequently the ridges become tuberenlated, the venter beromes much narower and the sides also tuberculated and the volutions more compressed. These spines, undes on the casts, are in three rows, but may be completely absent in some shells, as they are also in some old shells. In old age the venter again becomes fintened and smontl, amd finally broader and jommled.

The species are all comected so closely by intermediate forms that distinct lines ane difficult to draw between contignous species.

The ampresied and highly involnte yomng show that those species, like I'. gumlaluper, laving depressed rolutions with broal venters, ane senile forms in the phylum, or what I have named phylogerontic. They 
are not scaphitoid, as stated by Ifunier Chalmas, except in the sense that Scouhites is an extreme case of the same tendeney to reproduce senile chintacters early in the ontogeny and to such in extent that the ephebic form hecomes more or less influenced by them. The species form a series, therefure, leading off from shells, like $P$. sytale in one direction into $P$. gutulalupe and in the other intu whitfieldi. The intermediate modifications comnecting this genus with Protenyonoceas are jmobably partly represented by Ihiplacmoceras, but this genus is not a primitive, althongh it seems to be at phyoneanic form.

The solution of the species problem appears to lie principally in the development of tubercles and the correlative stoutness of the rolutions. Shells having heary tubercles in three lines usually also bave sutural peculiarities that enable one to distinguish them. "The peculiarities of the gerontic stage are also distinct, as will be noticed in the descriptions. In some species the neanic stages are quite distinct in their sutures, although alike in their forms at the same age, and perhaps with more materials the study of these and the derelopment of sutures may give good results. The most highly moditied form as compared with its own neanic stage is certainly gradchure, but although the sutures are complicated in ontline, they are not so complex as those of whitfeldi, and the modifications of form are distinctly in a plylogerontic direction. The varieties of each species and the derelopment point to the most prevalent syrtaloid form as presenting more than any other purely progressive characters. 'This form hats moderately compressed involute whorls, with three lines of nodes, narsow venter, and steadily romplicating sutures. The same variations in the species and in the individual point ensequently in one direction toward mudalupe and in another toward whitfietri. This last is reached through species like stmeni and psentoplerenta, in which the median lines of tubereles become permanently obsolete and the outer and imner lines become less prominent and in many specimens of rhitfichli are absent. The interesting fact in this connection is that whitfieldi, which, as compared with its own young, is the least modified of all the forms, has the largest shells, the least affected by gerontic degreneration, and at all stages the most complex sutures.

These farcts also show in a marked way the law of retardation of development. This was joined by Cope with acceleration, but so far as 
Iny experience goes they are quite distinct. Retardation oceurs in cephalopors in phylogerontic forms. Thus in this phylogerontic gemes the romog is a lightly morlified, compressed involute shell in the neanie stage: the adult in somp species like gumedupe and the European depressum may have additional noditications ending with a paragerontic stage also tuberculated, hut witl peenliar hroad venter and lateral nodes. In other species, obvionsly closely connected. like psemdosystale, newberyi, planm, - and linenean congener's like grossonvei and milleri, the first appearance of tubercles occurs lister in the ontogeny and they ane present in their full development only in the latest ephebic substage or gerontic stage. The same law looks also in the series leading from syrtede throngh intercalure and stantomi to whitfieldi. In some forms of syrtale and intercalare the three lines of tubercles appear earlier than in the typical forms of the same speries and in placentu.

In stentomi and pseudoplacenta this later appearance of tubercles becomes invariable and correlates with the disippearance of the centran line and a tendency to decrease in size of these ormaments on the venter and unbilical shonlders.

hu rhitfieldi this tendency results in the total disappearance of the tubercles in a large number of shells, three lines of tubercles being present mly in a very few shells and always of very small size, plainly individual reversions.

The sutures are simpler in ontline and contime persistently to hold the syrtaloid ontlines, and are ensily separable, except in extreme age, in all of the guadalupan series, including not only the stonter forms like guadalupe, but the highly compressed shells like flamm. In the series leading up to whitfieldi there is a morked gain both in complexity of outline and in gerentic clanacters. This is apparent in intercalure and placenta, which still rotain the tluree lines of tulsercles, and is still more pronounced in stantoni and psemdoplacente and colminates in whitfictdi. In these last the sutures are sinilin to syrtale only in the neanic stage, and in whitfieldi they become more rapindy complex in ontogeny than in other species and orerlap to such an extent that it hecomes more difficult to separate them thromghout the ephebic and gerontic stages. This orerlapping is a purely gerontic character, and the species that slow it during the ephebic stage are therefore pluylogerontic and to this extent degenerative in spite of the 
increase in complication of outlines of the lobes and saddles and their large size. This plyyogerontic elaracter is also accompanied, as stated above, by loss of ornamentation and retention throughout life of the compresisel, involute, smooth volutions of the neanic stage.

The living chambers are persistently one-half of a volution in length, whether oremring in depressed or compressed shells or in dwarfs, and the apertures, so fin as seen, have a short, blunt rostrum and low, broad hateral crests.

Grossonves aroful descriptions and axreptionally fine figures of the ditterent forms included under the name of Placenticeras syrtale show that while there exists in France and Germany a series closely parallel

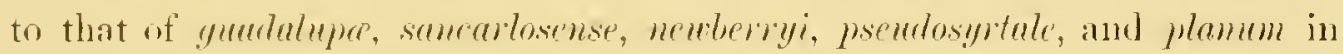
this country, all of the Eumpean shells present differences showing that the erolution of the modifications was distinct in France. The gerontic stages show a greater tendeney on the part of the imner lines of undes to grow farther wut on the lateral zones and approxinate to the venter, and the venter not only flattens out to a plano-convex outline, as in some Anerican species, but also in a subsequent gerontic substage, an in P. grossomei and milleri, beennes more or less concave. This is due to the increasing size of the tubercles of the median line on the borders of the venter after the disilpearance of the ventral lines of earlier stages.

Kossmat ${ }^{a}$ sums up the literature of the genus Placenticeres and its allies. The trpe of the genus Ruchiceres is erroneonsly considered as a species of Schloenbachiu. Schloenbachia is a genus with nomal outlines to the sutures. a derisive keel with chamels or smonth bands on either side, and more or less simnoidal, prominent, well-developed rostax, the aperture haviug a long, pointed rostrum correlating with the keeled venter. The development is also rery distinct from that of any of the Psendoceratites of the Cretaceons. In precerling pages, B. bilohatum is joined with other relaterl species, and the differences of the series to which it belongs can be more readily seen. Kussmat's strictures with regard to my own work on this group are just and most of his.objections well founded. IT reference to bohluri Keyserling, as the probable radical of Placenticeras nay be correct. At any rate there are some facts that favor this. The sutmes are similar to those of Placenticeras. The young of this species certainly 
lesembles that of some of this genus in having a channeled renter, but it is mucl, tou involnte and compresisel for a primitive trpe. The keel of bellowi is developed in the center of a buarl, concave renter of neanic age, as an ohtuse raised areal, but finally the entire venter becomes elevated with a subacute carina, like that of Buclicerces A raised nascent ked nua he sair to appear at a late age in some species of I'lucenticeras, but the venters in them are very narrow, and no such effect is produced as in buthuri. The rery narow clamnel of the andmeanic stage in this species and the late development of the tubercles produce resemblances to Thiplacmoreras, but in this genus the outer lines of tubereles are not on the ridges of the venter as they are in balduri. If this species is the ancestor of Hiplacmoceras, we have still to arcount for this and the fact that the nepionic stages in I'luceutiepres exactly mateh those of I'rotengonoceras and Knemireras and are nerer keeled as in Bucliceras and Roemeroceras. So far as Keyserling's drawinges go, the nepionic form of balduri before the chamel appears is like that of Bucherems and Tissotin serrata.

The separation of the genus Placenticeras fiom the Hoplitida " demands a fow words of explanation. Its association with Hoplites by Douville and Grossonve depends upon the comnection supposed to be shown by the large first lateral saddle of Hoplites sylculens. This saddle, as figured by these two distinguished authorities, has the thee large marginal lobes and three saddles which are supposed by them to be lomologous with the three principal laterals of Placenticeras.

'The anthor's position is quite distinct from this. If the three marginals of $I I$. splendens, having undoubtedly, as stated by them, great similarity to the principal laterals (first to third) of Placenticeras, are intermediate gratations and not a case of parallelism, some similar stage ought to be present in the development of species having three prinejal laterals. This, so far" as $1 \mathrm{know}$, is not the history of the development in any form of this kind.

It is disappointing and much to be regretted that no direct mention is nade of Prot. James

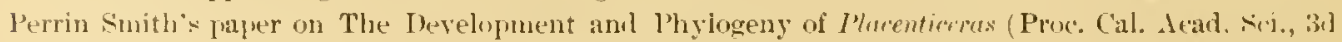
series, (ienl., Fol. I, 1)], 1s1-240), althngh incidental reference to it is marle in commection with the develument of the sutures. If Prof wor Hyatt had conpleted the revision of his manuscript, he

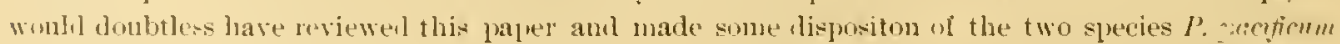

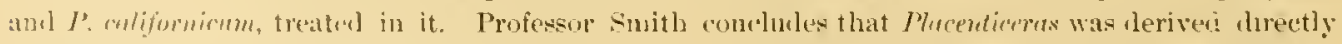

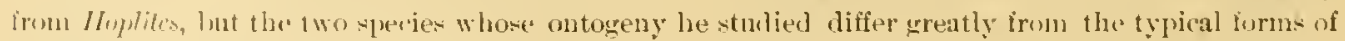

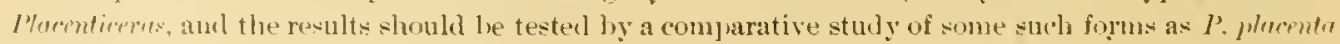
or millielsti.-T. W. S 
In all genera having but one principal lateral (IIoplites, Schloenbachin, Buchiceras), this lateral is a direct and closely comnerted modification of the primitive lateral of the young. Also in general laving two or three saddles these are not preceded by an internediate stage in which one large lateral arises like that of Schloenbachia and Hoplites splemdens, but on the contrary, these principal laterals arise through the continuous growth of the two w three primitive and more or less tongue-shaped and at first entire marginals that develop in the top of the primitive first lateral lobe, as las lately been shown by J. Perrin Smith.

When these are arrested in development and do not increase in conplexity and remain entire or become simply bitid or trifid, etc., the differentiation between them and the auxiliaries is lost and the sutures of the adult are similar to those of the Engonoceratidie and the like. When, however, these do acquire more complex outlines and the derelopment is duly progressive, its effect is invariably and natumally greater upon the sarddes and lobes of the outer side, which have free growth and are most called upon to help hold the animal in the shell. These, either on this account or for some other reason as yet unknown, certainly during development as a rule become more complex than the inmer laterals. This complexity is, as a rule, less in direct proportion to the distance of the saldlle or lobe from the periphery if an allowance be made for the natural division due to the greater or less persistence and sometimes more or loss independent development of the largest lateral lobe. This is the primitive first lateral in normal forms, but in retrogressive genera it may be, as in Placenticeras, the third marginal lobe of the primitive first lateral, as has also been shown by Smitlo. This greater development can be accounted for by the greater stress of the muscles at these median parts in balancing the shell while crawling. It interferes with the regularity of the gradations in size and complexity of the series, and marks the division between the principal or larger lateral lobes and saddles and the so-called auxiliaries.

In most groups of Ammonitine the first lateral becomes bifid and the centran marginal lobe is the first that appears. Usually the next saddle to become bifid is the first anxiliary. This occurs in Placenticeras, while the second and third laterals still lave entire bases. In other words, sinilar laws govern the development of the two series of saldles, the principal laterals and the auxiliaries, so far as the development of the first saddle of MON XLIV $-03-13$ 
each series is concerned. Subsequently, however, there is more irregularity. Thms the second auxiliary is not necessarily the next to become bifid, luut it is apt to be the next, and the process passes inward, the inmermost saddles being usually the last to become bifid, but there is great irregnlarity in the first appearance of bifidity ur division among the anxiliaries.

As a rule, however, this irregularity does not occur in the immermost saddle, which is often broad and remains entire later than its neighbors and is the last to show complications of ontline.

The second and third of the principal saddles in Placenticeras appear to reverse this law of progress inward. After the first has adranced to the tritid stage, it is the third which leads in complication of ontline and the second which comes next. This same reversion is found also in the furincipal lobes In this genus the primitive lateral lobe is continuous in derelopment with the third lateral, and it is this that first shows the trifid division, which is the incipient stage of complication; then the second follow, and after this the first. The last two, howerer, may progress in nearly equal ratio.

The second, third, and fourth auxiliary lobes are apt to follow the lead of the first auxiliary in regnlar snccession, but there is variation in this respect, as among the saddles. The general law, however, is the same as among the saldles, the innermost being the last to modify their entire primitive ontlines.

In the development of the sutures there are, however, two series to be considered, first the products of the development of the first primitive lateral saddle of the nepionic stage, and second the products of the inflections in ontline of the second primitive lateral saddle. These form two series of lobes and saddles on either side of the primitive first lateral lobe and ober different laws of develnment. The complication in the lobes froceenls from the oldest lobe, the primitive first lateral, outward and inwarl; the complieation in the saddles begins with the primitive first lateral and proceeds inward when that saddle is not divided in the neanie stage. When, howrerer, that saddle is livided into three, there is more or less irregularity in the progression in complexity of the outlines of the secomd and third saddles. The onter division or prineipal first lateral is, however, apparently always the one that grows fastest and leads off in acquining a more complex outline, as may be observed in abont all of the genera noted below. 
The tendency of the saddles to become bifid in their first stage of complication was noted by Brancen and since by Nickles, but in the lobes this varies. In these the first stage of eomplication is apt to be either bifid or trifid, according to the form of the entire lobe of the precerling stage. If these be pointerl, the next step in complexity is the fomation of a trifid top, if they be rommled or flattened, the next grade is usmally a bifid termination.

In the genera described below there is a notable tendency toward the formation of trifid lobew in all of the outer lobes and in a number of the auxiliary series, the immer and last anxiliary lobes showing a tendency to become bifirl.

The saddles and lobes in any wne suture of the genera which have arrester development of the lobes and saddles, and even in some like Sphenodiscus and Ilacenticeras with very complex outlines, show a graded series of modifications from the line of involution motwar. These have frequently such sinple entire lohes and sadrles near the umbilicus that one (am see at a glance that they are like the entire outer lobes and saddles of the young. The sutme, in fact, juesents a series of modified forms that show in a genemal way the history of the development of any one of the onter lobes or saddles, if it be traced from its entire stage to the suture which is being observed. This is due to the fact noted above and also slown in Brancos observations and the anthor's on the young, viz, that new lobes and saddles as a rule are adderl from the line of involution so that these in any extended snture line are yomnger or later introluctions. In some genera with arrested development these remain comparatively mmodified, lut in most genera of Ammonitine and in Ilacenticeras these do become nodified and have complex outlines in later stayes, although never so complex as in the outer saddles and lohes. When this modificatwom by development takes place these internal and younger lobes and saddles proceed or develop by repeating the stages passed through by their outer and more rapilly developed companions of the same sutures.

In ofler words, the lobes and sutures of Ammonitina exhibit the same law of repetition or parallelism in local development which was first discovered by Dr. R. T. Jackson among the Echinoids. He there showed that a newly introduced plate of the coroma passed though stages of modification in the course of its subsequent growth which were parallel 
with those which hat alpeady been passed through by the surounding phates of the corona dining the stages of the ontogeny.

In other words, there is a local ontogeny in newly introluced lobes and sathles parallel with the developmental ontogeny of the same rements, and, in wrowing, each newly introduced internal lobe w saddle repeats locally the same stages of derelopment. The arrest of development, which takes place habitually in all forms of Ammonitine, internally stops the progress of each lobe and sadule at different stages in proportion to the distance of the lobe or saddle of the anxiliary series from the line of involution. In genera like Engonocerts, however, the entire suture is arrested in development and presents therefore a certain resemblance to the young of other Ammonitins in the neanic stage and especially to the young of Placenticeras after the three entire principal lobes and saddles and the entire lohes and saddles of the auxiliary series have appenred. It may be objected that the division between the species is too minute and artificial, and it is admitted that this objection is in one sense well founded.

There is no real line between $P$. gruchalupere, suncarlosense, and planum,

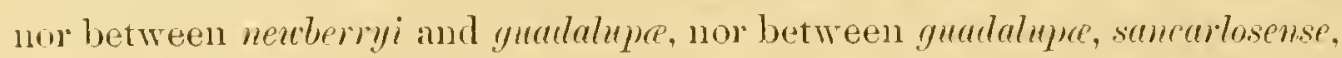
systale, intercalare, and placenta, nor between intercalare, stantoni, pseutoplacenta, and whitfichli. As a matter of fact there is no real break. snch as is nsually supposed to establish a species, between $P$. gumeduluse and the extreme form of whitfieldi.

If, however, one adnits that all Anerican forms make up only one species, it becomes illogical to separate the Emropean forms from each other or the American from them, and, consequently, all the forms of Placenticeras are one species.

I have not been able to find any middle ground between these two extremes, but have fomnd that it is possible to diagnose species by describing the normal forms, meaning thereby the shells that are most distinct and usually most numerons in each species, and adding thereto the mention of intermediate forms.

When this is done, it is seen that in this genus the separable forms or species cam be distinguished by their differences in development of the sutures, of identical onments, and of the sectional outlines of the volutions. The chnnges that take place in the aspect of the venter and of all characters in the senile or gerontic stage are included under the term derelopment, which in the sense here used means all the nodifications of the ontogeny. 


\title{
Placexticeras guadalupa" (Roemer).
}

\author{
PI. XXIX, figm. 1-t.
}

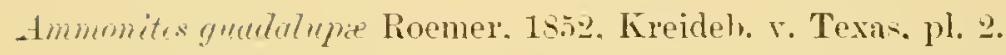

The best specimen I have seen has a diameter of about $145 \mathrm{~mm}$. Onter volurion on gerontic living chamber abont halfway to the aperture is 63 mm. and transterse diameter $47 \mathrm{~mm}$., the same volution opposite is $43 \mathrm{~mm}$, the transwerse being $3 t$ mm., aroiding the tubercles. The mubilici are deeper, the mmbilieal zones being more romnded and the involution greater than in psendosyrtale. The involution covers the inner volutions to the immer line of tuhereles, whereas in pseudosyntale these are not only completely murovered but well inside of the line of involution. The venter is very hroad, so that the second lines of tubercles are on its lateral angles and the first lateral saddles and lobes are on the rentral aspect. The altemating ventral tubereles and the flat ventral zone hetween then ane retained on the renter throughont the ephebic stage. The inner row consists of large acute spines, solid at the tips only, which are large nodes on the cast, at the start when the nmbilicus is only $25 \mathrm{~mm}$. in diameter. These recede outwardly with age, hut remain more jorninent than in pseulosyrtule at the same age and the imner ridges are also much larger. The aperture is partly preserved and is apparently at the end of the metagerontic substage, judging by the last sutures, which are not closely approximated, and by the aspect of the last tubercles. The marrin of the aperture has a sinus near the line of involution and broad lateral crest, but beyond this it cond not be seen. The renter is convex and elevater in the gerontic stage and had a ventral zone as described above. The volutions are stouter at all stages than in psendosyrtale. Having broken open this specimen, it was ascertained, as I har expected, that the young is nore compressed and slender than the outer rolutions, although in most Immonitina the reverse of this is true. The rounded nepionic volutions were followed as in other

"Mr. T. W. Stanton has courteously commented as follows upon this species:

"The original spelling 'guadalupe' shonld be restored. The name of the river is 'Guarlalupe.' The type locality should le given 'Waterfall of the Guadalupe letow New braunfels' where the only hurizons representerl are the top of the Austin limestone ant the lower part of the Taylor beds. The - frecinens from san Carlos are from besls probably of ahout the same age in a formation to which Mr. Ilill has given the local name San Carlos berds. The Fort Worth locality [allnding to the specimen with that locality in my collection] must be inaccurate, as there are no [pper Crelaceus beds within severas mules of that place." 
species by the compressed and deeply involute volutions of the neanic stage, and these acquired first the flattened venter and helmet-shaped section and then, as the rentro-dorsal diameters lengthened, the hollow venter bordered hy smooth ridges and general aspect of I'rotengonoceras. The facts were ascertined hy excaration as well as ly studying the section.

Unluckily the sutures were northere exposed in these immer volutions. The anxiliaries were visible later in the neanic stage after the volutions hand become more compressed. They were then of the syrtale type, but their simple ontlines showed that in the preceding Protengonoceras age they must have been rery simple in ontline and perhaps similar to those of Emyonoceras. The norles on the cast did not begin to appear on the mubilical shonlders mitil the shell was about 35 to $40 \mathrm{~mm}$. in thameter and had entered upon the ephebic stage. The outer row of spines were not risible until later, and the age at which they appeared, except that it was later than the neanir stage, conld not be ascertainerl. The ephebic stage has a stout volution with giblons sides with proportions entirely different from those of the gerontic stage. At diameter of 26 mm. from line of involution to venter the transverse diameter at umbilical shoulders is $15 \mathrm{~mm}$. and at $6 \mathrm{~mm}$. distant from the renter the transverse diameter is $11 \mathrm{~mm}$. The lateral zones are nearly flat and muly slightly convergent and then converge rapidly but convexly to the venter which is broad, being here $5 \mathrm{~mm}$. The last part of the neanic stage is 11.5 by $5 \mathrm{~mm}$. at the umbilical shoulders and the convergence of the faintly convex lateral zones outwarlly is constant to the renter, which is $1.5 \mathrm{~mm}$. in breadth. The gerontic rolution on sane section is 45.5 by $35.5 \mathrm{~mm}$. at the umbilical shoulders and between mbercles; the plano convex renter is $27.5 \mathrm{~mm}$, also between tubercles. The ventral line of tuberdes and the concave area or ventral zone disappears in the gerontic stage, and the last measurements were taken after their clisappearance near the basal sutures of the living chamber.

Roemer's fignes are excellent, but they show in specimen much larger than mine, and but just entering the anagerontic substage. Roener estimated that his shell, when complete, must have been a foot in diameter.

The living rhamber of loemer's specimen was broken away, or it would have shown similar gerontic chanacters. There is a centran trave on the renter of lioemer's figure which is present also on the renter of the ephebic stage in my cast. The trace is double, consisting of a faint depres- 
sion between equally faint ridges. There is also a faint trace on the venter of the neanic stage, but it is then a single line sunk in the surface of the shell. It is too faint to be visible in any section, and is probably not present in the younger stages.

In the neanic stage the rather large siphuncle is at a perceptible distance from the shell of the venter, but in the ephebic stage it is directly against it, and the double trace may be dne to this.

The sntures are more widely separated in. Roemer's figure than in my specimen, but this may be dne to more vigwous growtlo. There were eleven saddles and ten lobes on the older sntures, with less complicated outlines than in pseudosyntale, but otherwise similar. The sutures are well separated at all stages, but the last two are nearer together than the preceding. The rentral lobes are deeper and narrower and the siphonal saddles more prominent and distinct than in other species. except that describer by Choffat $n$ Portugal as $P$. uhligi. It stands between this primitive form and $P$. psentosyntale and other Anerican species, all of which have rery bruad rentril lobes and less prominent siphonal saddles.

A very fine suite of this species was collenterl by Stanton and Vanghan, locality 1467, United States Geological survey, Sin Carlos, Presidio County, Tex. The largest specimen is $204 \mathrm{~mm}$. in diameter'; a part of the aperture at the umbilical zone sliows on one side and the length of the living elamber is somewhat less than one-half uf a volution. 'The gerontic stage is present and the involution is considerably decreased along the outer sides of the nodes on their retreat firm the nmbilicus. The renter becomes broader and rounded on the last part of onter volution. The onter nodes change from round spines to elongated costax, dichotomons with the immer line of nodes that are nearly at the middle of the lateral zones at this age.

There are some more compressed specimens that still, however, have very stout volntions and a prolonged stage, during which the venter becomes broadened and occupies the space between the second rows of nodes, the outer ventral rows forming lines on either side of a zone occupving the center of the rentral surface. These features are still like those of typical guadalupe, but in other cases it is impossible to say whether the specimens belong to typical guctulupe or to the next described species.

Locality: San Carlos, Presidin, Comnty, Tex.

Age: San Carlos beds, Upper Cretaceous. 


\section{Placexticeras sancarlosense 1 . sp. Hyatt.}

I'. XXX, fim. 1-3: Pl. XXXI, fig . 1. 2.

This is represunted by a series of specimens in collections marle by Stanton and Taughan that farle into true guadulupe.

The trpical forms differ in having smaller tubercles, the compressed stage is more prolonged and the ephebic: volutions are never so stout nor the venter so broad as in gradulupe. 'The stage in which the renter is broad and bounded by the second line of undes and similar to that of grachalume is short and is often distinctly confined to the anagerontic substage. Some of the specimens of this forn are very closely similar to I. sylute. 'This last species has, however, so far as known, no stage in which the venter resembles that of guadulupe, i. e., in which the renter becomes bradened ont while tle rentral lines of tubereles and the lateral nodes are still preserved in nearly their full development. This form is obviously an exact parallel with the $P$. pseudosyrtale said to be found at Fort IVorth, ${ }^{a}$ but from this it is separable by the involution which is more considerable and follows the innel line of tubercles. There are dwarfs belonging to this species which lave more pronounced tuberenlations than Placenticens nerberryi, but these approximate very closely to the specimens from l'residio del Norte, and show that these last are really another grade of modifications laving the same general tendeney.

Locality: San Carlos, Presidio Comnty, Tex.

Aye: San Carlos beds, Upper Cretaceous.

Placenticeras sancarlosense variety Pseldosirtale Hyatt.

P. XXXI1; Pl. XXXI11, fig. 1.

The type of this variety is a well-preserved cast $200 \mathrm{~mm}$. in whole diameter. The last volution from lines of involution to renter, although much affected by senile contraction, is $80 \mathrm{~mm}$. and the same volution opposite is $65 \mathrm{~mm}$. The rentro-dorsil diameter is $73 \mathrm{~mm}$. about half way the lengtl of the living chamber, ant the transverse diameter is $53 \mathrm{~mm}$., avoiding the tuhercles. The same ventro-dorsal dianeter at last septum, taken always from line of involution to venter, is $63 \mathrm{~mm}$. and the transverse, aroiding the tubercles, is $43 \mathrm{~mm}$. The tubercles of first inner row alternate 
with those of the opposite sicle: the outer row is nore numerums than the imner, and there are slight indications of bifurcated ridges of costre connecting them on the cast. The ventral tubercles are irregularly alternate with the second row and there may have been ridges hifureating more or less between these, but there ane no indications of these on the cast.

It is rery like Worton's species, but the gerontic stage begins later and the increase of the ventro-dorsal diameters is much more rapid. The wirth through the umbilical shoulders is greater at the same age and the lateral zones flatter and nore convergent, owing to the greater prominence of the umbilical shoulders. The rentral lines of tuberoles are more elongaterl, not so close together, and quite different, and the second immer line of tuhercles is less prominent and nearel to the vertical lines. The inner lines of tubercles do not appear until the ephebic stage and alce at first rer'y minute but rapidly enlarge in the remainder of the ephebic and gerontic stage, disappearing suddenly before the onter ones at the heginning of the paragerontic substage. They recede from the umbilical shoulders outwardly in the parephebic and germtic stages and have an inner costation or ridge inclined apicad.

The outer line of tubereles disappears in the paragerontic substage immediately after the inner line. 'The rentral lines of tuberoles disappear on the cast in the metagerontir: substage. These tubereles are present on a bit of the thick rentral shell in the ephebic stage. These are almost linear, alternating and widely separated, and border a slightly concare ventral zome, which is, howerer, flat upon the cast at the same age. The rentral zone continues well defined and flat upon this cast until quite close to the aperture in the extrene of the paragerontic substage. 'The contraction of the gerontic volution is rery marked, beginning, even in the parephebic substage, before the gerontic septa appear and apicad of the base of the gerontic living ehamber.

The sutures have the aspect of those of syrtale, but the outlines are more complex and the third lateral lobes longer and more pointed. This does not appear to be due to greater age, hut correlates with the larger size and other differences in the form and development of this specimen. There are eleven lobes and twelve saddles on each side in anagerontic septa: the inmermost saddle is narow and apparently entire, all the remainder divided and bifurcate except the first laterals. In these the 
inner arm extends inwardly and, being itself bifucater, gives a trifurcated aspect to each of these saddles. The inner lobes are bifurraterl and lnomlen outwardy, being somewhat blunt or rounded exeept in the third lateral, which is pointed and apparenty of the bifureated type, as are also the otluer lobes. The last fou sutures are more or less approximated, and the last two and part of the third interfere, as in $I^{\prime}$. placentu, except near and on the venter.

The living chamber is one-half of a rolution in lengtls. The outer paut of the aperture is preserved, showing a blunt, broad, rounded rentral crest, or slight rostrum, rentro-lateral sinuses on the second line of tuhercles, and the appearances indicate broad lateral crests, but the margins were broken away inside of this. The approximation to $P$. sencurlosense is so close that probably most paleontologists will prefer to consider them identical, but the lateral nodes are larger and more quickly developed and the ventral tubereles more elongated and more widely separated. The extrenety thick slell is shown as well as the fact that the rentral tubercles are not more prominent on the thick shell than they are on the cast.

Locellity: Fort Worth, Tex."

Age: Probably same as gruedalupe and sancerlosense.

\section{Placenticeras planum 11. sp. Hyatt.}

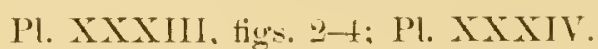

This is also a part of the collection made by Stanton and Vaughan. This species also grades into $I^{\prime}$. sancarlosense althongh very distinet from qundulume. The sides are almost smooth, the tubercles being rery small and obscure, except in the umbilicus. The affinities for guadulupe and its allies are denonstrated by Mr. Stanton's are in collecting this fine series. The flat, compressed aspect of the young is maintained until the shells reach a dianceter of $221 \mathrm{~mm}$., and the renter does not show any broalening out until after the shell reaches the gerontic stage.

One of the specinens from Presidio del Norte, No. 21651, is $240 \mathrm{~mm}$. in diameter. Four-fifth of the outer rolution is in the gerontic stage, but the first part of the parephebic substage shows the renter still narrow, flat, and tuberculated. It then becomes rounded, but the volution still remains conn-

"Mr. Stanton has commented as follows upon this alleged locality: " $I$. sumcurtesense var.

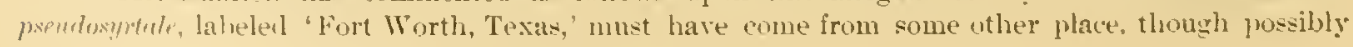
in that region." (Sere note on I'. (ntadrlupar.) 
pressed. There are small tubercles in the umbilicus but these disappear in the older stages, and almost the entire onter volution is smooth. The other specimen has similar character's, and the sutures are of the gradulupe and syotale type.

This species is not separable in some varieties from $P$. newbrryi, except by the absence of large lateral nodes at all stages.

Locality: San Carlos, Presilin Comutr, Tex.; Presidio del Norte, Mexico.

Aye: San Carlos beds, Upper Cretacents.

Placenticeras newberry 11. sp. ITyatt.

PI. XXXI, figm, :3-5.

The type is a cast with small patches of shell. Liameter is $120 \mathrm{~mm}$, to which inust be adder perhaps $5 \mathrm{~mm}$. for depression of onter volution. The dianeter of the whole coil me-fourth of a volution younger and not altered hy depression is $94 \mathrm{~mm}$. The outer volution at aperture is $54 \mathrm{~mm}$. and transverse is $39 \mathrm{~mm}$, the rmbilicus is $24 \mathrm{~mm}$. and the opposite part of sane volution is $42 \mathrm{~mm}$. and transverse $28 \mathrm{~mm}$. The last volution begins with transterse dianeter of 19 mm., enlarges in the next quarter of a rolution to 28 mm., and just beyomi this the large gerontic tubereles begin. The transverse diameter continnes to increase until the last quarter apicad of the aperture is reached, and then it diminishes between the two last tubercles, which are widely separated, and still further dininution takes place at the aperture. In annther specimen there is no diminution in the rate of growtle of the transwerse dianeter aplenent to the eye, but this specimen has not a complete living chamber. The ahnost scaphitean aspect of the living clamber in some specinens is misleading and is in part due to depression. Nevertheless, this only exaggerates the germic metamorplioses of this interesting species. Small nodes are present in an early ephebic substage on the unbilical shoulders and continue to increase, becoming rery large suddenly in the anagerntic substage. Elongated tubercles are present an either side of the venter in the ephebic stage, but the age of introduction was not ascertained; apparently it is later than that of the tubereles on the umbilical shomleters.

The latter are wirlely separated at all stages, but the ventral tubercles are close together. There are rery obscure fold-like costix, some of them 
dirhotomoni, on the onter pant of the outer volution on the cast, but these lare no perceptible middle now of tuhereles in the ephelic stage. The venter increases in the gerontic stane from being 5 mm. wille between the lines of tubereles to $20 \mathrm{~mm}$. on the first half of the onter rolution, and this contines to grow broaler and nume conver motil near the aperture, where there is an apparent diminution. As the venter bradens, the costa are hronght to the edges of the venter and their terminations hecome enlarged inte rown of nodes as the gerontic stage frogresses, but disappear in the paragerontic substage as the venter lumalens and the surface of this becomes smootl on the asts.

The living chamber is somewhat less than one-half of a volution in length. It has very deep sinuses on the umbilical zones and prominent lateral crests. The form of the rentral margin was not seen. The mbilicus is deep, the internal volution visible, the umbilical shoulders are prominent, and the umbilical zones ane steep and brual, as in other species of this genus, fiom a comparatively early age.

The sutures are of the guadahnean syrtule type and well separated, becoming approximated only in extreme age. There is only one change, howerer, of considerable interest in the gerontic stage dne to the broadening ont of the venter. The ventral lobe does not broaden in the same proportion, and consequently in this stage the first pairs of saddles and finally furst lateral lobes become included within the onter line of tubercles, thus becoming transferred to the venter, as in $\Gamma$. guadalupre. Another specimen (No. 11975 a) from the same locality is more compressed, has somewhat less prominent tubercles, and not so deep umbilicus. In the interior of the type specimen the venter of the later part of neanic stage with slell on is exposed. This shows the nsual compressed form of this stage in other species of this genus, the venter narrow, smooth, concave, as in I'rotengonoceras, and the volution also resembling that of that species, but at this time it is of comse more discoidal. The largest specimen of the more compressed variety reaches a dianeter of $134 \mathrm{~mm}$. thrombly the hase of a living chamber aml when complete must have been comsirlerably larger.

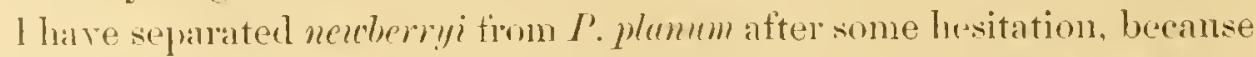
of the entire absence of the peeculiar tubereulated zone of ymatalupes on the hroadened venter of the gerontic stage, the more obsenre tuberculatimns, and the more compressed young. The second row of nodes is more 
persistent in the type specimen than in other fossils, and this may be a specific character, although the condition of other casts does not enable me to determine this.

Locality: Presidio del Norte, Clilmahna, Mexico.

Age: Probably same as guadalupe.

Placenticeras syrtale (Morton).

Pl. XxVII, figs. 15-17; Pl. Xxvili, tigs. 1-6.

Ammonites syrtatis Morton. 1534. Syrnop. Organic Renains, pl. 16.

Morton's original specimen is probably a dwarf. At any rate, the shell is in its magerontic substage, and the large nodes given in Norton's figure belong to this age. The dianeter is $75 \mathrm{~mm}$., and it is consequently smaller than the specimen of rar. halei below described; nevertheless the gerontic stage has begmn, as is shown by the great enlargement of the last pair of tubercles and the depression of the venter, and there is no living chamber. When this was present, the diameter was probably about the same as in the Alabama specimen. The tubercles appear earlier than in rar. Kalei and are larger at the same age.

A specimen from Fort Worth, which shows the typical characters of the figure given by Morton, is $97 \mathrm{~mm}$. in diameter. The outer volution is $42 \mathrm{~mm}$. from line of involution to venter and the opposite is $31 \mathrm{~mm}$. The large size of the umbiticus is due to the recession of the onter volution, which is in its metagerontic substage, and the shell consequently was ahmost wholly outgrown. It has the lauge inner norles, and as these are not so numerous as the next outer row of smaller ones there is a distinct aspect of bifurcation in the fold-like coste that here and there connect them throughont the ephebic and gerontic stages. The venter has a narrow, concave zone bordered by elongated tubercles forming a crenulated border on either side in the ephebic stage. These are more closely set than in var: halei from Alabams. The inner row of nodes, ats in $P$. intercalure, does not hold to the line of the umbilical shoulder, but recedes outwardly in the gerontic stage, and this stage comes in much earlior than in interculure in all of these specimens.

The renter has become rounded on the outer quarter of the last volution, the ventral line of tubercles being lost. The lateral nodes, however, remain prominent, showing that the last or paragerontic substage of senile development has not been reached. The outer row is nearer to 
the venter at all ages than in $P$. intercalare, and the volutions are stonter in all specimens of the latter that approximate in their markings to this species.

The sutures of syrtale at the same age as that given by 1 Ieek (Invert. L'al., p. 471) have the same broad first lateral saddles, but the other saddles are not so wide as those figmed. There are, however, the same number, viz, 10. Ther are all minutely digitate except the tenth, which is entire. The living chamber is fully one-half of a volntion in length, and part of the aperture preserved shows a broid, blunt lateral crest.

This form is obvionsly rery smilar to $I$ '. intercelare and may be, if one chuses, considered on one side to be identical with $P$. sancarlosense and on the other with $I$. intercalure. From the former it can be separated by the renter, which is not so broad at any stage, and by the early disappearance of the rentral nnbereles in the gerontic stage, and the fact that the venter becomes rounded only in extreme age and is never flattened as in nexberyig and its close ally, sancarlosense.

It can also be separated from intercalure, but the characters are more dubions It is certainly so close that the differences in the specimens so fiur known might be considered as due to the same canses that dwarfed the stature of the shells. The young, however, appear to be more compressed at the same age in syrtale.

Lorality: Greene Connty, Ali.; Fort Worth, Tex.

Aye: Probably Taylor marls in Austin limestone, Upper Cretaceous ${ }^{a}$

\section{Placenticeras syrtale vas: halei Hyatt.}

Pl. XXVII. figs. 16. 17: Pl. XXVIII, figs. 3-6.

This is found in the Hale collection (Boston Society Natural History, No. 8577), and approximates to polyopsis of Lujardin. It has, howerer, nunch heavier lateral nodes and costre in the gerontic stage. The young in the later neanic stage, judging from the fragment studied, can hardly be

"Mr. Stanton has most obligingly written as follows:

"Locality: 'Fort Worth, Tex.' It is not at all probable that the specimen came from For IForth, thongh it may have been fouml some niles east of there.

"Age: Cpper Cretareons, probally Taylor marls or Austin limestone.

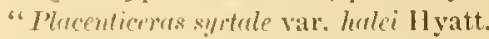

"Jocality: Greene County, Ala.

"Age: This specimen is probably from the Eutaw heds, which are frobably very near the horizon of $I$. gucululupir, in Texas." 
separated firom the young of $P$. bolli, although the tubercles of the imner line are less prominent at dianeter of $45 \mathrm{~mm}$., the rolution being $23 \mathrm{~mm}$. and greatest transrerse dianeter $11 \mathrm{~mm}$. When the volution is $43 \mathrm{~mm}$. from lines of involution to venter in same cast, the nodes in both lateral lines are very-large and the ventral tubercles large, the rentral zone becoming simnous on the cast in consequence of their size and arrangement. The renter also begins to show rotundity immediately after this, thus introdncing the gerontic stage; the lateral zones begin to lose their flattened aspect, becoming more convex, the umbilical shoulders becoming correlatively rounded. The inner lines of norles in this species are also apt to be elongated into ridges directed apically, as in polyopsis Dujardin. In the parephebic substage the volution from line of involution to venter in cast is $41 \mathrm{~mm}$., transverse diameter between nodes, which are not close to umbilical lines of involution, as in earlier stages, but abont $14 \mathrm{~mm}$. distant, is $26 \mathrm{~nm}$., and throngh the nodes, which are probably somewhat worn down, it is $30 \mathrm{~mm}$. In a more complete cast of $90 \mathrm{~mm}$. in whole diameter, which has lust a trifle on the venter by weathering, the same romding of the venter. begins when the volution reaches about $32 \mathrm{~mm}$. in ventro-dorsal diameter from lines of involution to venter. The nodes enlarge rapidly in the parephebic and gerontic stage of these two specimens, and fold-like costre appear which are obscurely bifurcated at the imer line of tubercles. The immer nodes are eloneated, and have heary, although not very prominent, folds on the mibilical zones which bend sharply apicad. The rentral zone gives place to a rounded area, as in the above, and the imner nodes are about $10 \mathrm{~mm}$. distant from lines of involution instead of being only a few millimeters renoved, as in earlier stages. They are, however, still on the umbilical shoulders, and, therefore, in same position as in the young with relation to the sides.

Loculity: Greene Comnty?, Alabama.

Age: Eutaw beds, Upper Cretaceous.

I'Lacenticeras intercalare Meek.

Pls. XxxV-XxxviI: Pl. XxxviII, fig. 1.

Placenticeras plucenta var. intercalare. Mleek, 18\%t, Mon. U. S. Geol. Surr. Terr., Vol. IX, pl. 23.

This was identified by Meek with placenta, but its characteristics were fully given by him and its relations to Ammonites syrtalis of Morton and 
the true placenta correctly defined. In some parts of his text he also "peaks of this as "Macenticeras intercalare," so that he is the sole anthority for the combined names as used in this description.

The ventral lobe as figured by Meek is very distinet from that of $I$. whitficldi, as are also the entire sutures. This lobe is narower, the branches are of the syrtale type, the siphonal saldle is more elerated, narrower, and is subdivided by a median marginal lobe with a minute bifid saddle: but these distinctions, except in a general sense, do not hold, since there are the same types of siphonal saddles in whitfieldi. The drawings by Meek, when compared with the originals, are accurate. The specimen on plate 23 is in the ephebic stage. 'The sutures overlap as much as in whitfieldi. A specinen having external shell in part preserved, from near Black Hills, South Dakota (purchased from Professor IVard), is 208 mm. in dianeter. The last part of onter volution from lines of involution to renter' is $112 \mathrm{~mm}$., the first of the same being $50 \mathrm{~mm}$. 'The greatest transrerse dianeter of the volution when it is $95 \mathrm{~mm}$. is $44 \mathrm{~mm}$., and when $50 \mathrm{~mm}$. it is $29 \mathrm{~mm}$. The volution is somewhat stouter than in whitfieldi and the involution somewhat less. 'The venter' is a little broader and is bordered by two rows of tubercles of good size. These tubercles quite suddenly show decrease in size, and become much nearer at the same time on the last of third and on fourth quarter of this volution. They are present on both cast and shell. On the last part of onter volution they are almost obsolescent. On the first part of the living chamber they are opposite, then becone again alternate, and as they decrease in size are again opposite. The ridges on the venter are slight, except in one short space, where they first become opposite. The shell has mmerous bands of growth. The chevrons are particularly prominent on last part of this rolution and run into and form several longitudinal ridges on the onter half of lateral zone, while the costre are represented only by rery broad, hardly perceptible, folds. The tubercles of the middle line are of grood size and become olssolete on the last quarter, changing at the same time with ventral rows of tubercles. Large tubercles are present on the umbilical shonliters, which sensibly decrease at the sinme time and also recede guadually from the shoulders outwardly. These nodes are elongated. forming parts of the costa that are more perceptible in their neighborhood. The ontlines of the rentral zone are not simous between tubercles. 
There is a thick, opaque, horn-colored outer layer, an intermediate crimson-red layer, and an imer nacreous layer of the usual color. These consist of a number of minor layers as in other shells of this genus. The sutures have broader lobes and narrower saddles than in whitfieldi and placenta, and the ontlines of these are somewhat less complicated and not so overlapping. The ventral lobe has the same narow character and syrtale-like branches, with large siphonal saddle, as in Meek's figure of $P$. interculare, but the siphonal saddle is smooth and entire on the venter, as in $I$. whitfieldi, and also has the same minute marginal saddles on either side of this entire center. A finc youn specimen of this species, from Sage Creek, South Dakota, No. 2104b in collection of Yale Museum, at diameter of $80 \mathrm{~mm}$., shows the begimning of the large tubercles of umbilical shoulder, the rentral tubercles, and apparently those of the middle row to be on the furst quarter of its outer volution. This shell must have been smooth and similar to $P$. placenta, perhaps, even in the sutures, when the diameter from line of involution to renter was about $15 \mathrm{~mm}$. At later stages the sutures are distinct. Another specinen, same locality and collection, at diameter of $132 \mathrm{~mm}$., shows thee rows of tubereles distinctly risible on both cast and shell, No 2104a. The median lateral lines of tubercles disappear on the last quartel of the outer rolution in this specinen, but the rentral inner rows persist. As long as the median rows of tubercles exist the shell has a transverse cutline distinct from that of whitfieldi at any stage, but when these disappear it is difficult to separate this specimen fiom whitfieldi. I have not yet seen a specimen in which the rentral rows of tuberdes disappear, but whether they do on not it must he impracticable in some specimens to seprarate them from ahitfieldi var. tuberculatum, although most specinens are distinct on aceount of the size and persistence of all of the tubereles.

A fine specimen from same collection trom Sage Creek, South Dakota, (No. 1s63) at diameter $144 \mathrm{~mm}$, lass alleady passed well into its gerontic stage, whereas the specimen figured by Meek is not so fur advanced in age. The first part of the last rolution is considerably compressed, as in Meek's figure, but on the living elamber on the last half of this volution the whorl becomes stouter. This chamber is apparently nearer complete and about one-half of a rolution in length. All three lines of tubercles persist and the ventral ones which are alternate in the ephebic stage are approxinately yox XLIT-03-14 
opposite in old age and are sometimes comected by a ridge, so that the veuter is serrated. The inner line of tubercles recedes in this stage, as in specoimen figured by Meek.

The sutures have shorter, stouter saddles than those figured by Meek, and are nore like those of $P$. syrtale. In the first lateral sadalles especially they are more decply cut into by the lobes that broaden out apicad, and the other lobes and saddles are like those of intercalare, as figured by Meek. The resemblances to syrtale occur nore markedly in old age, when the body of the first lateral saddles loses the thread-like tenuity of the ephebic stage and becomes thicker. All the saddles do not show these changes equally. This last specimen has enabled me to make comuections with No. 18975 C. S. National Museum, from the Upper Missouri, which is a nearer appraach to syrtale. The inner nodes on this last are about the same, but me not partly buried by the involution and make their appearance somewhat earlier in the neanic stage. The outer line of tubercles are larger and the venter is monder. The sutures, howerer, and the proportions, etc., of the volutions are about the samo. Lastly there is a fragment in same collection, locality No. 1720, 5 miles southeast of Harpers Station, Laramie Plains, Wyo., that 110 one would think of separating from syrtale by the external characters. The diameter is $94 \mathrm{~mm}$, and the speemen has the same wide umbilieus, stout rolutions, prominent nodes, and sharp ventral tubercles as that species. The sutures, however, although the specimen is so small, are almost as excessively complicated in outlines as in Meek's fignre, although this was taken firom a murh larger rolution.

One specimen, No. 9735, L. S. National Museum, from Ponil Canyon, New Mexico, has clanacters just intermediate between $P$. intercalure and I'. placentu. The young and full ephebie stage has the form of the stouter specomens of intercalare with thee rows of tubereles. The two nuter rows are, however, more delicate than usual in intercalare, especially the median lateral ones, which are very small and widely separated as in I'. placentre. Lnfortmotely the last of the ephebic and the first part of the gerontic stanes are missing, but the parts left show similarity with the old age of I'. plurentu and intercalure. The venter does not broaden out exeept very slightly while becoming rounded as it does on the third quarter of the outer rohution. The sides lose the ahrupt elevated umbilical shoulders and heeome evenly anvex, but the involution continues to follow the umbilical 
line of tubercles. The rentral lines of tubercles persist on the outer rolution, but are very faint and finally disappeas. The same is true of the other lines of tuhercles, all of which finally disappear in the paratgerontic stage. The shells of this species do not apparently lave the gerontic enlargement of tubercles into heary blunt nodes which is common in gueulupre and its allies, suncarlosense, planum, and also syrtale. The sutures are like those of syotule and less complicated than in intercalare at the same age, but this appearance is probably largely due to the fact that they are less crowded and to not overlap.

Loculity: Black Hills region.

Age: Fort l'ierre erroup, Upper Cretacems.

Piarenticeras placenta (l)ekay).

PI. XXXIX, fign. :3-6; PI. XL. figm. 1. ㄹ.

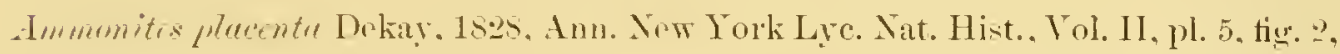
not fig. 3.

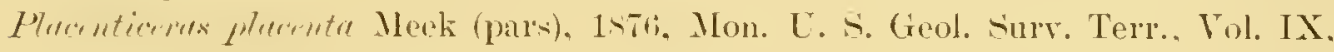
p. 465.

Plecenticerts plueente Whithipld (pars). 1592. Mon. U. S. Geol. surver, Vol. XVIII, pls. 4 i). 41 .

This species is represented in the Musem of Comparative Zoologr by a large fragment from New Jersey 101 mm. in diameter from line of invulution to venter at hase of living clamber, and this last is about onc-lalt of a volution in length. It is a cast and sinootl on the sides, with the exception of a line of fold-like tubercles on the depresser umbilical shoulders. 'The ventral zone, even at this stage, obviously fully gerontic, is flat and $7.511 m$. broad as estinated.

The last sutures have not so highly complicated ontlines as whitfieldi, but the lobes are long and narrow, the first and second laterals highly inclined apically. The fourth lateral is about two-thirds as long or only slightly shorter than the third lateral lobe. The saddles are not so deeply divided as in whitfieldi and broader and more solid. 'The last two sntures are approximated, but the third, althongh partly preserved, is at the usual distance and shows that this is not the same as the western form described by Meek as placenta. The sutures of this large specimen of $P$. placenta have exactly the outlines given by Whitfield in his figure, and a similar, 
althongh perhaps older, siphonal saddle has numerous denticles or marginal saddles. The median marginal lobe was not quite so plain as in Whitfield's figure, but this might have been owing to age or variation in sutures or the condition of the cast. Meek, as well as Whitfield, included under placenta sereral species which are separated in these descriptions, but Whitfield recognized and described the differences between the western and the New Tersey specimens and considered them as probably distinct. I have consedpently named the western species whitfieldi in recognition of this finct.

The specimen described above enables me to add the following: The venter is not rounded on the smaller end of this cast, but flat, having the same form as whitfieldi, but broader than in that species; subsequently, althongh not well preserved, this part appears to become rounded. This specimen shows that in extreme age the rolution is shorter and has more gibbons sides than in whitfieldi and shorter ventro-dorsal diameters. The decrease in involution due to senility is also more marked, and takes place at a smaller size. This species stands hetween syrtale and whitfieldi in this respect and in its sutures and other characters.

There are several fragments in the Hale collection of the Boston Society of Natural Ilistory, supposed to be from Greene County, Alabama, which have saddles with more solid bodies or basal parts, as in true placentn These indicate a species of larger size than the associated species of I'. syrtale, having rolutions with smooth flat sides and smooth renter, as in placenta. The sutures agree very closely with those given by Morton for I'. placenta from the cut of the Delaware and Chesapeake Canal, and one specimen shows a rounded venter. The examination of the fine suite of original types and specimens in the Mruseum of the Academy of Sciences of Philadelphia gave the following results: The septum of this species is much thatter, having only a very slight double curvature in place of the very marked double curvature of whitfieldi, and this is less apparent on the suture line than on the surface of the septum. On a volution 63 mun. from line of involution to renter, transverse diameter is $2.2 \mathrm{~mm}$. and there are three lines of tubercles. The lateral row is two-thirds of the breadth of the sides, nearer the venter than the dorsum, and very small and widely separated, but still quite distinct. The tubercles on the venter. of placenta are large and elongated like those of bolli and much coarser and 
less numerous than in some specimens of whitfieldi. These disappear in the ephebic stage, together with the lateral line of tubercles, and in some specimens the latter may be entirely absent as in young specimens figured by Whitfield. The large originals of Morton's figure and of Whitfield's show these figures to be approximately correct. The renter is in all stages broader than in true whitfieldi, but remains flat only through a small part of the gerontic stage. In two specimens, $365 \mathrm{~mm}$. and $425 \mathrm{~mm}$. in diameter; one Morton's type, from cut of Delaware and Chesapeake Canal, the living chanber was practically complete and abont one-lualf of a volution in length. The rounding of the renter begins in these on the still separate part of the second quarter of the outer rolution. Near the aperture the venter is completely rounded and the decrease in the rentro-dorsal dianeters between the lines of involution more marked than in whitfieldi, and the umbilici are consequently larger. The sntmes vary from having very solidlooking saddles as in Whitfield's figure to those with the first to thind saddles almost indistinguishable from those of some varieties of whitfieldi. Upon the whole, however, it is safe to say that while the siddles of placenta may be as deeply undercut and the necks as thin as in whitfieldi, the basal parts are, perhaps, always less completely eut up by the marginals. These and the auxiliary saddles have, howerer, as a rule, a bifid aspect with a large median marginal deeply dividing them, and this seems to be a distinction of more importance, especially in the aspect of the auxiliaries. The poportions of the diameters are also quite different. In the ephebic stane the transverse diancter may be more or less than one-thind of the diameter. from line of involution to renter and in nld age it may be more or less than one-half of this samw dianeter. A young specimen of diameter of abont 60 to $65 \mathrm{~mm}$, is in conlection of the Academy of Sciences of Pliladelphia. In the neanic stage this cast had lighly compressed smootl volutions as in whitfieldi, but the unbilicus is larger, the involution being sonewhat less, apparently. The three lines of tubercles begin on the first part of the onter rolution or just before, when the shell is abont $45 \mathrm{~mm}$. in diameter. It this stage the lobes and saddles are distinctly placenticeran. The saddles are all bifid, but the entire ontlines have given place to completely denticulated outlines over both lobes and siddles, even on the innermost anxiliaries in the older parts of this cast. 'The sutures at this age are very similar to those of syrtale and gualahuse. 
Until a late age this shell is separable from stantoni w psendoplacenta by the presence of the minute median lateral line of tubercles. The larger - size and wider separation of the rentral tubercles separate the younger stages, in which the renter is often rery narrow and the sutmes similar to those of uhitfieldi, from var. tuberculatum of that species. The sutures, howerel, as a rule, have less complex outlines and more solid-bodied saddles and less concare septa, as stated ahove.

Locality: New Jersey, Alabama.

Aye: Matawan formation (clay marls), Lpper Cretacenus.

Placentickras staxtoni n. sp. Hyatt.

IMacenticepes placentu Stanton (pars.), 18:4, Bull. L. S. (?ool. Survey No. 16m, pl. 39, tigs. 2.2 , not tig 1 .

Locality: Upper Kanab Valley, Utah.

Age: Coloradio epoch, Lpper Cretacents.

Placenticeras stantoni variety bolli Hyatt.

PI. XL. tigs. 3-7: Pl. XLI: Pl. XLII: Pl. XLIII. tigs. 1. 2.

Plucenticenas intrealare Meek (pars.). 1s7r. Mon. UT. S. Geol. Surr. Terr., Vol. IX. p. 471 .

This species is rery like $P$. placenta and whitfieldi, but has much stouter volntions with broader venters at the same age and is intermediate in character between intercalare and whitfieldi. The costae are of the syrtule type, but are merely obscure folds on these casts. The tubercles are sparse and on the umbilical shoulders as in plucenta. The costre are occasionally bifid on the outer part of the side with single ones between them. The elongated rentral tubercles are alternate and each one lias its costation. The sutures have much shorter lobes and stouter, shorter saddles than in placentu.

The young in the nepionic stage have a smooth rolution with rounded venter. In the neanic stage this changes through the elevation of the venter. The ventral zone is at first quite broad comparatively and perfectly flat in the neanic stage. In the ephebic stage it becomes much narower and concare and probably then acquires its tubercles. The tubercles on the umbilical shoulders do not appear until this stige begins. 
The lateral angles of the single coste, and still more the junctions of the dichotomous coster, when these occur, tend to rise up more prominently than the rest of the costation as in other forms, but they do not in the specinens examined, as in syrtale and intercalare, become tuberculose. The specimens from which these descriptions were taken are in the Museum of Comparative Zoolog:

This species is distinguished from $P$. placenta by the shorter and stouter lobes and saddles and the better separation of the sutures at all stages except, perlaps, the yomigest. It stands apparently nearer to $P$. syitule in its sutures than to intcrcalare, but this is due to the fact that in intercalare the sutures vary from those like syrtale to as complicated as in Ileek's figures, and if the comparisons are made witl the former, it is seen that the external chancters and sutures place it between interculare and whitfieldi, on account of the suppression in botl of the lateral line of tubercles. A specimen from Dallas Connty, Tex., has similar nurkings and sutures so far as scen on the young volutions, and is probably the gerontic stage of this species. It is an incomplete living chamber ahout one-half of a volution in length, with the inner volutions attached but badly crushed. The latter shows the large imner row of nodes and the sutures in part, and these last agree closely with those of the specinen described above.

The volution from line of involution to venter at base of living chamber is $75 \mathrm{~mm}$. in diameter, transverse diameter about $40 \mathrm{~mm}$, and at one-fourth of a rolution distant from this the clianneter is $91 \mathrm{~mm}$. The renter is broad, and the ventral zone convex on the cast at the two last septa. The tubercles are almost obsolete and the costse completely gone, the cast being smooth with the exception of one obscure broad longitudinal ridge on the centran surface of the laterul zone. The remnants of tubercles are shown in obseure and rery slight folds with a decirled apical trend. This description shows that the gerontic stage is quite distinct from that of placentr o1 whitfieldi.

The basal suture is very complex in its outlines, but las the short saddles and lobes of this species. The next younger septum is, however, closely approximated to the last. The first and second lateral lobes are very narrow and the saddles approximate. The lateral lobe is also narrow. The remaining lobes and saddles are more like those of the younger stages, but also have narrower lobes and broader saddles. These sutures are quite 
distinct from those of other species and come nearer to those of the old whorl of $P$. placentu from New Jersey than any other form. They are, lowverer, smaller, and the apical trend of the onter lobes is less, the third lateral being shorter, and the remaining lobes more abruptly separated through their extreme shortening up as compared with the third lateral.

Having received through Professon. Martin the specinen described by Meek from Tarrant Comuty, Tex., as belonging to $P$. intercalne, I am able to state that it is a good cast of this species. The diameter is $90 \mathrm{~mm}$. The living chamber is inconplete but nearly lialf of a volution in length. The median lateral line of tubercles is absent, the imner line of small tubercles recedes from the umbilical shoulder, and the ventral tubercles ale rather coarse and large, and the venter broad as in trpical bolli. The sutures have the solid short saddles and short lobes of this form. The paraphebic substage is reached near the aperture.

Loculity: Ehm Fork and West Fork, Dallas County and Tarrant Comuty, 'Tex.

$$
\begin{aligned}
& \text { Age: "Probibly Eagle Ford slates" (Stanton) } \\
& \text { Placexrtceras pseudoplacenta Hyatt. }
\end{aligned}
$$

Pl. XLIIT, figs. 3-11; Pl. XLIT.

Placenticeras placente (!) Stanton (pars). 1s!t. Bull. L. S. Geol. Survey No. 16t. pl. 39, fig. 1 (not figs. ……)

The sutures are peculiar and unlike those of any of the forms of true P. placenta or whitfieldi. This fact was noticed by Stanton, who considered the Colorado species to be different from true placenta. In confirmation of these remarks I can add the following: A large fragment, U. S. National Ifuseum, locality Upper Kanab, Utah, No. 22344, diameter from line of incolution to ventel $88 \mathrm{~mm}$, greatest transverse about $35 \mathrm{~mm}$., shows a wider venter $6 \mathrm{~mm}$. and flatter than in whitfieldi at same age. The side which is unaffected by pressure is not so evenly convex as in that species, the cuter part being rery slightly concave, the centran part slightly vibhous. The sutures exhibit more complicated ontlines than in the younger stage figured by Stanton, but they have similar ragged outlines and rery broad lobes and are ohviously the same. A specimen with diameter of $35 \mathrm{~mm}$. has on the last rulution sutures with same rugged 
aspect but very much simpler in outline than those of $P$. whitfieldi or even those of true placenta at the some age. The perfect venter at this stage is concave and it continues smooth and concave in this species until the shell is much larger, but then becomes flattened and apparently exactly similar to that of true $P$. placenta, but is broader at the same age and flatter than in 1'. whitfieldi. 'The sutmes are more like those of $I$. placenta than those of P. whitfieldi. The casts do not show the shell except in the young stage and this has obscure sigmoidal bands of goowth like those in whitfielli but no coste on the shell and none on the casts as is usual in that species. The yomgest stage is more involute than in $P$. placenta and is like some specimens of $l^{\prime}$. whitfieldi in this respect.

Stanton's figure of the suture was taken from the ephebic volution of a specimen of the diameter of $173 \mathrm{~mm}$ 'The volutions were perfectly smooth on this cast, with a flat, broal renter, and at the liameter given on the third quarter of the outer volution the gerontic stage had hegrun and the last part of the volution was helmet-shaped in section with a rounded renter. This shows a paragerontits stage earlier than is usual in placentu or in erlitfieleli.

The specimen alluderl to by Stantom, from Ellis Countr, Tex., Eagle Forl shales or Fort Benton Gromp, is a cast $171 \mathrm{~mm}$. in dianeter, with forn alnost as much compresserl, and with thin venter, as in relitfieldi, but the sutures are more like those of stantoni. They are, however, more deeply cut, heing older than those figmed and more like those of whitfieldi.

In fact, I do not see here nor elsewhere any possibility of drawing sharp lines, exrept between the genera; the species all rum intu one another.

Loculity: Epper Kanab, Utah; Hnerfano Park, Colorado.

Age: Colorado Epoch, Upper Cretaceous.

Placenticeras paeudoplacenta variety occinentale Hyatt.

PI. XLV, figs. 1, 2.

The saddles and lobes have the elongated forms of those of P. whitfichli, but ane more solid; the ventral lobe has the same elongated anms, and the ventral saddle is also similar, but the lobes and saddles are simpler and more like syrtale until a later stage than in $P$. whitfieldi. The shells have a row of tubercles on the umbilical shoulders and fine tubercles on the venter. The principal distinction is, however, the breadth of the renter 
and its flatness in the epliebic stage, which is similar to stuntoni and placentu. There are, however, sone specimens with smooth venter, as in whitfieldi. A specimen in the collection of Colmmbia Lnirersity, New Iork Citr, So. 106226, from Lpper Missouri River, las a diameter, partly estimated, of $150 \mathrm{~mm}$. The last volution, with living chamber, is 76 mm., partly estimated; the muliliens is $22 \mathrm{~mm}$., and opposite the same rolution, form line of involution to renter, is $52 \mathrm{~mm}$. The volution is not so flattened or compressed, laving slight ventral tubercles and slightly nore gibbous sides than in whitfieldi, and volutions not so deeply involute, as is shown by the brearlth of the mmbilicus. The line of involution is outside the line of internal tubereles, and this more open aspect of the umbilicus and the solid aspect of the satdles and forms of the lobes agree nore closely with the smaller form of placenta figured by IVhitfield and are quite distinct from true whitfieldi of the same size.

The living chamber is incomplete, but oceupies about half a volution in length, and the aperture follows the bands of growth. The siphonal sarklle las several minute denticulations even at this early age Futures at dianeter of $26 \mathrm{~mm}$, from line of involution to renter, showed distinctly the syntule trpe of outline which occurs in whtfieldi, only at a much earlier stage, short, lnoal saddles and corresponding lobes, with well-separated outlines and no appearance of bands free of sutures on either side of venter.

No. 8238, U. S. National Museum, from Cow lsland, Cpper Missouri River, Furt l'ierre or Fox Hills Group, is a very interesting fragment of this form. It is a good-sized frament, slowing the inner and onter rolutions, with broad venters and proportions stouter than in typical psemloplucentu or whitfeldi. The tubercles on the venter are not large, but quite plain. 'They disappen' on the last of the onter' rolution, while the imel' line persist, and there is no median line. There is on the last part of the outer rolution, in the beginning of the gerontic stage, a distinct elevation along the line usually occupied by the median lateral tubercles, which I have never seen in whitfieteli, and which usually acems only in syrtale, interculure, and the more heavily tubereulated forms. This is also apparent in the full eplotbic stage, but is less marked. The sutures are very smilar and, in fact, not distinguishable from those of whitfeldi in some rarieties. I have, in consequence, placed this shell under name of pseudopiacentu, althongh in general aspeet it really seems to agree better with stantoni. 
One specimen, a fragment given by Dr. R. T. Jaekson, said to have come from Bad Lands, near Black Hills, South Lakota, is $73 \mathrm{~mm}$. from the lines of invohution to the venter at suall end, and $88 \mathrm{~mm}$. at a distance of $110 \mathrm{~mm}$., measured along the centran axis of the side, or somewhat more than one-fourth of a rolution farther on, the whole length being $160 \mathrm{~mm}$. This fragment is a living chamber, the last septum and the aperture being partly preserved. A restoration of the whole coil shows the diameter of the entire specimen to have been about $174 \mathrm{~mm}$. The obsolescing costa, sparse and small tubereles on umbilieal shoulders, and small, more closely set tubercles on the edges of the venter, show that this is probably the parepliebic stage of this species.

The renter has become romded, or rather the previonsly concave zone has become convex, but the rentral tubercles, although faint, are clearly discernible at the oldest end of this fragment.

Thus the gerontic stage must have begm in this speeies at a size when the ephebic stage was not yet completed in $P$. uhitfieldi or placenta. The saddles of the hast septum show mueh less eomplex ontlines than in uhitfieldi. The third lateral lobe was not entirely preserved, but it was obvionsly not so long. The outlines resemble approximately those of bolli. Dissecting out a part of the ephebic volution contained in the zone of involution, the shell and the sutures also were found perfectly preserved. The probable diameter of the rolution at this age from line of involution across side to venter was about $35 \mathrm{~mm}$, and the whole diameter of coil perhaps $75 \mathrm{~mm}$. The shell at the younger end of this fragment, which was about one-fouth of a volution, showed a decidedly eoncave venter; the east was also slightly concave. At the other end, while the shell was still concave, the cast was flat on the venter. The tubercles on the younger end were well defined, but mere fine crenulations, as in $P$. placenta and whitfieldi. They were barely perceptible on the cast at this end of the fragment, and not visible at all on the cast at the other end, althongh, as stated above, present on the cast of the gerontie living chamber. The sutures showed somewhat more solid branches on the saddles than in whitfieldi, and rentral lobes and siphonal saddles like those of $P$. intercalare. Previous to eracking out this fragment the specimen was classified with variety bolli. The cherron markings on the nacreous layer were beantifully displayed and very instructive. At the younger end they had the normal orad direction for abont an inch, then 
some accident had happened fracturing the edges of the aperture on both sides and causing a slight sinuous constriction on both sides when growth was resumed. Beyond this the direction of the chevrom lines was reversed on the right side in a median depression and on the left along a slight corresponding elevation.

One fragment from Elm Fork, Dallas Comnty, 'Tex., in the Museum of Comparative Zoology, not quite one-lualf of a volution in length and measuring $230 \mathrm{~mm}$. in diameter, has these characters, but the umbilicus does not appear to be quite so large in proportion. The aspect of the saddles enables one to separate these from rar. tuberculatum of $P$. uhitfieldi, but it is probable that these two are connected. As I have repeatedly stated elsewhere, I consider this rarietal comnection no argmment for uniting these ubviously distinct species. This specimen has large marginal saddles on the siphonal saddle, and a distinct marginal median lobe, which becomes slightly trificl in later stages. On the left sicle of this are entire slightly phylliform saddles, and on the right a bifid marginal. These become subdirided later. 'The rentral lobe his the long arns of the whitfieldi trpe which are not similar to those of the same lobes in the syrtule type.

I propose, in following the inclications of these observations, to confine this name to those forms of this genus having broad venters and more immature sutures than in whitficlli at all stages of growth. The edges of the venter may be either finely tuberculated or smooth. The sides may be smooth o "with a median line of very obscure elevations. The inner line of tubereles is developed, but does not appear at an early stage.

Locality: Elm Fork, Dallas Comnty, Tex.; Upper Missouri, Bad Lands, South Dakota.

Aye: Probahly Fort Pierre group, L'pper Cretaceous.

"The following note has been kindly added by Mr. stanton:

"Placenticerus presedoplerente var. occidentale 11 yatt.

"Locality: Lpper Miscouri. Barl Landls, South Dakota.

"Age: Fort Piere srrup, Cpper Cretaceous.

"The specimen from the Barl Lands is certainly Irom the Fort Pierre, and the one from the Upper ILissouri probably is alsn.

"The sprecimen labeled ' $P$. peudoplarenta var. omidentrle' and also 'var. intermedium' from Ehn Furk and West Fork (Horton's mill), Tallas (onnty, Tex., if the locality can be trusted, is prohably from the Eagle Furd slales, which are about equivalent to the Fort Benton." (The locality referred to is trustworthy.-A. H.) 
Placenticeras whitfieldi $\mathrm{n}$. sp. Hyatt.

Pl. XLV, tigs. :-16; PI. XLV1; Pl. XLVII, figs. 1-1.

Placenticeras plucentu Meek (pars). 15i6, Mon. L. S. Geol. Surv. Terr., Vol. IX. pl. 2t, fig. 2.

This species ean be distinguished from true P. placenta of New Jersey and the supposed western members of the same species by the following characters. The highly compressed volutions are more involute and the venter is namower throughout life and less completely rounded in old age, and this change comes in only at a much larger size than in the shells of P.placenta. Owiug also to the absence of the median lateral line of tubercles the rolution his flatter sides. All tubercles are wanting in typical forms at all stages, but very fine tubercles are present on either border of the venter and larger ones on the umbilical shoulders in some shells. Sometimes ninnte tubercles are present on the median part of the lateral aspect, but these oceur only in the neanic stage, disappearing with the ventral tubercles in the eplebic stage. The sutures are more complicated in the romng and are more orerlapping than in placenta. The saddles are almost linear hecause of the excessive development of the lobes, which are very long and narrow. These differences hold with the materials so far examined. It must be remembered, however, that as ret no eximination of a large number of specimens of buth species fiom the sime locality has been made, and it is likely that there are intermediate shells. Certainly no one can distinguish these species muless familiar with both forms or having both for comparison. The same naly be said of $P$. intercalare, betreen which and this species there are intermediate shells in P. whitfieldi var. tuberielutum.

1 made special examination of the rentral lobes of whitfieldi in all arailable speeimens. All had the peculiar very broad rentral lobes with long narow branches on the lateral aspects except in rare cases in which syrtale-like or blunter arms were present. One specimen had the long narrow am on the right side and a blunt syrtale-like arm on the left side. As a rule the rentral lobe is symmetrical, but the siphomal saddle is often unequally develoned or out of place. This sarldle is often entire and flat, so that one is apt to regard this as the normal form, but variations are so frequent that only large numbers of specimens could determine the facts. 
This saddle may hare a sinple median marewal sardlle or be trifid with three saddles, equal on unequal in size; or it may be bifid, with both marginals algain subdivided, or of any shape between these and such irregular simuons ontlines that it is difficult to describe it. It is almost invariably sunken between two marginal saddles, one on either side, but occasionally even these blend with the central part of the siphmal saddle.

A specimen from Cheyenne liver, South [akota, in the collection of Columbia Lniversity, New lonk City, reaches $327 \mathrm{~mm}$. in dianeter and has the basal part of a living chamber present. The venter begins to be rounded on this living chambered part. There is a slight decrease in the amonut of inrolntion at the same time, showing that this is in its gerontic stage. In 11 other specimens, in collection of the Boston Society of Natural History, and sent me by Warl, ranging in size from $110 \mathrm{~mm}$. in dianeter to nearly the climensions of the specimen last described, the typical form was observed. No tubercles were present, and the first lateral saddles were very narrow and rery deeply cut by almost straight and very long marginal lobes and saddles.

In all of these there are cherron marks more or less shown, and the sutures are similar, with the exception first mentioned. The first three lateral lobes are not very steeply inclined apicad, and the fourth lateral is nearly or quite two-thirds as long as the third lateral.

Altogetler I have seen perhaps 40 specimens.

A specimen from South Dakota, in collection of the Boston Society of Natural History, which is $113 \mathrm{~mm}$. in diameter, slows the costa and the "hevons, but the costre are quite fold-like. There were no tubercles on the elges of the ventral zone nor on the umbilical shoulders. The smallest part of the cuter volution was about $30 \mathrm{~mm}$. and the widest part about 60 mm. from line of involution to venter.

Some of the fragments of volutions examined must have belonged to shells fully 15 inches in diameter, the size of the specimen from New Jersey figured by Iforton as $P$. placenta, but none of these slowerl the gerontic degenerations in the ronuding of the venter as in his figure. The wider separation and the simpler outlines of the sutures found in lis figme also orem only at a comparatively early stage in this species. The eplebic stage has narow concave renter on the thiek shell and flattened zone on same area in the cast. The sides are perfectly smooth, with faint sigmoidal, allunost obsolescent, constie. 
Meek fignes a specinen just entering upon the eplebic stage, and these costre are faintly indicated. It is, in fact, difficult to see them, and they can be felt better than seen in some specinens. The costre are often quite linear and listinet on the shell in the neanie stage, but are not present before or after this stage. The divarienting ridges described and figmred by Meek as lines lare bern described above as lateral eherrons with the apices pointing arad and occurring only on the outer thirels of the sicles of the shell. They are rery plain on the imner layers of shell and faintly indicated on the cast and entirely independent of the growth bands. It an older stage (probably the netephebic substage) than that figured by Meek they are quite broken ar interrupted by the bands of growth on one side where the macreous layers are preserved, and on the other, in which part of the onter layer covers them, they are not visible. They are apparently characteristic of the neanic and part of the ephebic stage. The renter retains its flatuess until the slell is very large. The sutures are really at considerable distances fiom each other, but the siddles are so deep and the lobes so bong and narrow that the external outlines alle approximated except on and near the venter. The first lateral saddles are straight and narow, and there is consequently a band on either side of the venter in casts which is not eut up by intemingling sutures. On breaking down a specimen sent me by Professor. Ward the young at diameter of $11.13 \mathrm{~mm}$. fiom line of involution to venter lad the first four saddles even at this early stage more slender and more deeply cut by the marginal lobes than in the sperimens supposed to be young of $l$ '. placenta of the west at diameter of 2.5 mm. The lobes and saddles were also longer and narower in proportion, the sutures nearer together, and the branches of the ventral lobe larger and lomger and the rentral sadule with langer marginal lobes at exactly corresponding ages. 'The ventral renulations ol tuberculations are not in persistent as in plucente of the west, since they disappear in all of these sperimens in the ephebic stage.

The incomplete living chamber is about one-half of a rolution in length.

'The first volution of a specimen in the collection of the Muserm of Comparative Zoology, from Clifford, Nebraska, lias a depressed rounded goniatitic form with a single constriction in this specimen at the end of the first quarter. The lateral sutures along the sides have the broad lateral 
saddles: the other's were correred and could not be seen. The only exposed suture immediately preceding the constriction las entire outlines. The ventral lohes are moderately deep and straight-sided, with large, undivided siphonal saddle. The first lateral saddle is rounded and broad, but entirely mon the renter, as is also the first lateral lobe. The latter is also rounded and wide at base and not so deep as the ventral lobe. The second lateral is magnosellarian in outline and reaches to the small lobe formed on the line of involution. It is interesting to note that in this lighly degenerate form of the Cretaceous the sutures exactly resemble at this age the adults of the Primordialida, which have mdivided siphonal saddles, and the rolution on section has the semilunar anarcestian form of the nepionic stage in Ammonitine. ${ }^{a}$

Near the end of the first rohntion the first lateral saddles and also the magnosellarian saddles have hegm to show minute dividing lobes. The form in section las at the same time changed to helmet shape through the eleration of the renter. The zone of involution at this age begins to increase and in the next rolution extends orer nearly the entire side of the first whorl. In consequence of the helmet shape and flatness of the siles the inrohtion, which is about two-thirds, appears to he greater than at any subsequent stage, whereas it is proportionately less. The ananeanie substage begins on the second volution. The sides become flatter, more convergent, and the venter is narrowed and flattener on the cast and slightly concave on the shell. In the metaneanic this change is completed by the rapid increase of the dorso-rentral as compared with the transwerse diameter. The renter still remains quite broad and does not attain the narrow aspect of the adult until in the latter part of the neanic stage on the fourth rolution. The umbilical zone begins to develop in the andneanic substage and steadily increases in brealth and steepness thereafter. The auxiliary lobes and saddles begin to appear in the paranepionic, and as the rolution increases in the rentro-dorsal dianeter more of them are introduced by the further division of the magnosellarian siddle, or rather what remains of this, in the mubilical zone. The process of division continues throughont the neanic stage, the additions being made internally on the umbilical shoulders and zone. They arise as simple indentations and grow tleeper with age, the digitations being introduced gradually by 
minute inflections of the outlines. The saddles are not so long as to interfere with deciphering the outlines of the lobes mntil the fourth volution is reached and the anephebic substage begins. Before this the sutures resemble more those of $P$. bolli, having shorter saddles and probahly at still earlier stages they are even more like those of this species, being proportionately shorter and with simpler digitations. There are nine lobes present on the last quarter' of the third rolution. 'The three principal lobes hare their nsual proportions, and the rentral lobe is nearly the same as in the adult, but the siphonal saddle is not so prominent, and the minor saddles on the sides of this are also much smaller and more nearly of the same size. There are six lobes on the lateral zone, a serenth on the shoulder, and two on the umbilical zone. The saddles are all distinctly bifid, except the tenth, which is not yet differentiated. The lobes are all of the trifurcate type, except the ninth, which is not fully dereloped and is single or unsymmetrical. The lobes and saddles greatly increase in complication of outline and becone larger and larger, but the number remains stationary on the fifth volution. Mleek" figures a rery large suture with twelve lobes.

Tubercular elevations make their appeannee on the edges of the rentral zone in the neanic stage, but they are more perceptible to the tonch than to the eye. The widely separated sigmoidal coste are more distinct, but the deep apical bend is only one-half developed and ends abruptly in some with a faint tubercle. The ventral part of the bend is apparently absent on the fourth volution, but subsequently appears more decidedly on the last quarter of this volution. Internally the oral bend of these costa is also deficient in the neanic stage, appearing to be better developed in an ephebic substage. Nevertheless, when one looks at the rolution, he is apt to see only the inner half of the deeper apical bend. The cherron-like folds are present on the shell in the later neanic substages and may come in earlier. A line of very faint, hardly perceptible, tubercles appears on the umbilical shoulder on the fifth volution in an ephebic substage.

I have been as minute in my descriptions as the specimen in hand permitted, because the presence of these indistinct tubercles and costre in the neanic and early ephebic snlsstages show, together with the more widely separated sutures and hroader venter, that the young are quite similar to those of placente and have also traces of their affinity with the more heavily

a Mon. U. S. Geol. Surr. Terr., Yol. IX, p. 466.

yON XLIV-03- 15 
tuberculated and stonter forms P. bolli. The same characters also show that these species are not identical, since they are not so strongly developed at any stage as in other species, and are succeeded by distinct sutures in the nearly full-grown shells. This study suggests also that the western species was deriverl from the eastern form.

A specimen purchased from L'rofessor Ward, locality Bad Lands, near Black Hills, South Dakota, shows the typical sutures and form of whitfieldi. The first lateral saddles in the ephebic stage have the usual three nearly equal marginal sardles and lobes, and there are no tubercles nor any coste appreciable to the eve at diameter from lines of involution to venter of $101 \mathrm{~mm}$. 'These sutures, however, have one peculiarity, probably of essential service to this investigation. In so far as the first two saddles and lobes are concerned, they are appreciably distinct, the first saldles being entirely free. The remaining parts of the sutures overlap more or less, as in almost all of this species. In the anephebic substage, or last of neanic stage, however, the diameter of rolution being $33.5 \mathrm{mmn}$., the costre are alparent and have the usual form, but are very taint. The chevrons are especially well shown in the fossil, although not more prominent than in many other specimens. They were plainly seen on this fragment, broken ont of the langer volution, and there appeared to be some comnection between these at their line of convergence and the indistinct longitudinal ridge or trace, which is obrionsly the centran lateral ridge seen in some older shells. The sutures are similar to those of the adult at the diameter of $24 \mathrm{~mm}$. from lines of involution to venter, but they are easily separable by the eye.

The earlier probably paraneanic substage dissected out from this was perfect and measured $26.5 \mathrm{~mm}$. in diameter of the coil. The larger end of the rolution in this was $15 \mathrm{~mm}$. from line of involution to venter, and when the rolution was abont $11 \mathrm{~mm}$. in sane diameter the chevrons and costie and excessively faint longitudinal ridges began to appear. There were as many as three of these along the centran lateral aspect of the valution and shorter but discontinuons ones arising from the chevrons. These comld anly be seen by careful and prolonged observation of the nacrems layer, which was preserved on one side. The sutures were less crowted than in the young one above described and favomable for observations at diameter just noted. There were ten lobes in all, including one 
on the line of involution. Six were on the lateral zone, one on the sharply defined umbilical shoulder, and three on the umbilical zone. The last saddle showed a distinct marginal lobe, the next saddle single, the succeding saddles were also bitid and had entire outlines, the fourth had begun to show marginal digitations, and the remaining saddles were more or less deeply eut, having approximately the forms of the ephebie stage, but being", of course, much simpler. The outlines of all of them were free except those of third and fourth saddles and those of the third lateral tobe. The nmbilical lobe is probably entire, as is the next lobe; the eighth is symmetrieally trifid, the vext fiom its position on the umbilical shoulder is unsymmetrically tritid, the next lobe on the side is symmetrically trifid again. The remaining lobes show ephebic division already defined but simpler than in the adult, and the same is true also of the ventral lobe and saddle, and the bare spaces on the cast on either side of the venter would be as conspienous as in the later stages if the sutures were as close together. One thing is noticeable in this specinen; the slightly yomger sutures on the same volution are for a time slightly eloser than the succeeding ones, owing to a temporary decrease in the rate of growth of the shell. 'This specimen had sutures quite different from the sutures of the small srecimen above described, in which at the same age there were approximating and even decidedly overlapping ontlines, as in the adnlt. The outines themselves, however, were about the same in both specimens, so that the differences were nerely those of the slower, less vigorous gowth of the forms as compaled with that now being describerl.

At the begiming of this volution, when the dianeter from lines of involution to ventel" is $7 \mathrm{~mm}$., the mubilical zone is just begimning to be formed. The ventral sardle at this time is just begiming to show digitations on its sides, and is broad and lange with flat concavity aeross the venter. The first lateral saddle is clistinctly trifid, the second and third laterals with chub-shaped bases and alnost entire, showing only the faintest possible trace of the median marginal lobe that rlivides them in the succeting sutures; the fourth lateral has this marginal lobe more distinct, but still very small, and the remaining saddles are entire with somewhat flattened basal lines.

'The arms of the ventral lobe and the rops of the first and second and third laterals are unsymmetrically trifid, the fourth lateral is just begiming 
to have a median marginal division and is bifid, the remaining lobes being entire and rery small and narrow. The trend of the sutures is abont the same as in adults, but the bend at the fourth lateral sardlle is more abrupt, the fourth lateral lobe being a scant one, abont one-half the length of the third lateral. This proportion begins to alter soon after this, and approximates to that of the adult before the end of this rolution. The number of lobes and saddles is the same; they are simply smaller in size and more primitive in outline. A very slight amount of exposure acts upon these sutnres and alters the ontlines, destroying the marginal lobes and saddles. At this time, i. e., $7 \mathrm{~mm}$. in diameter, the sntures are somewhat more prinitive on the left than on the right side of the volution, an irregularity that subsequently becomes less noticeable. There is probably nothing abnormal in this, as it is rare in any animal to find the two sides exactly similar. The costæ begin very early when the volution is about $7 \mathrm{~mm}$. in dianeter from lines of involution to venter.

In the ananeanic sulsstage, when the rolution is 4 to $5 \mathrm{~mm}$. in dimeter, the ventral zone is chameled, as in later stages, and sensibly broader in proportion. The form of the sutures, ete., is the same, but the digitations are less noticeable. The first lateral saddle on the most perfect sirle of this volution is faintly trifid, all the remaining saddles are entire and clubshaped except the smaller ones beyond the fourth, which are now plainly seen as mere inflections of the ontlines of the magnosellarian saddles. The arms of the ventral lobe are single, the first and second laterals are beginning to show trifid tops, while the third is broader and more chb shaped, and shows four nearly equal marginal lobes just beginning to appear. The rentral saddle is broad with coneave base, the dependent marginal saddles being alssent. There were nine lobes at this stage, but the ninth on the line of involution was very minute.

The next break exposed an earlier age in the ananeanic substage on the first quarter of the same volution. The renter had just beconce flattened and the edges of this zone are faintly crenulated m the cast, owing apparently to the presence of extremely fold-like costat which eross the venter. These are so indefinite that they were perceived witl difficulty.

The sutures are extremely instructive. The rentral lobe is as deep and as brout as the ventral zone; the ventral saddle is very small and divided by a siphomal lobe. The sides of the first lateral saddles are 
straight, and on the edges of the rentral zone the bases are entire and rounded. The first and seeond lateral lobes and the first, second, and third lateral saddles appear as inflections on the inner sides of the broad nepionic first lateral saddles. The thind lateral lobes oceupy the positions and are obviously the direct local representatives of the primitive primordialian lateral lobes. A large saddle, the prinitive magnosellarian saddle, occupies the inner part of the sides and two ninute narginal lobes and saddles are apprarent on this. The first marginal saddle, the forermner of the fonth and fifth saddles, is flat on the base and beginning to show an initial median mareinal lobe; the futme fourth lateral lobe, the inner saddle, las similar form but is still entire. This and the other specimens show that the great length of the third lateral lobes and the apical bend in the sutures and septa of aduls are due to the retention of nepionic characters and that the great complication in the details of the ontlines and the large number of lobes and saddles are based npon primitive nepionic outlines. This is also apprarent in the internal double curvature of the septa, which are concare along the center and convex like those of most Ammonitina only at the dorsal and rentral lobes.

A fine yommg specimen, No. 18936, U. S. National Musenm, Upper Missouri, enables me to add the following: Whole diameter is $55 \mathrm{~mm}$., and the fourtl volution is abont cimmpleted. On the early part of this rolution the sutmes are the same as in the young specimen above deseribed. The characteristic deejly cut sudlles and lobes of the westem form are already begiming to appear and the first, second, and third lateral lobes lave about the same proportions as in the adult, but the fourth lateral is only about half as long as the third lateral lobe. The sutures in this specimen are not so distinctly separated as in the young one at same age referred to, and are almost as closely intermingled as in the adult. The usual band free of sutures oecurs on eacl side of the venter. On breaking down this speeimen the sutures on the last quarter of the third volution were found to be more distinetly separated, the margins becoming simpler, but the peculiar bands free of sntures on either side of the venter are still present, and the species conld hardly be mistaken even at this

a The external shell is preserved in the umbilicus, but there are no tubercles, and venter is smooth on the cast of this part. The outer layer of shell of the list quarter of fourth volution is preserverl and shows fame markings as above describerl at about same age in young specimen from Nebraska. 
early stage on account of the much compressed wholly smontl volution and narrow concare renter with slightly elevated acute ridges on either side on the east. At this age imer sardlles assume a primitive rounded form with expanded base and one marginal central lobe; the imner lobes are trifid. Two specimens in the collection of the Boston Society of Natural History, collected by Prof. W. G. Crosby, have the typical characters and form of $I$ '. Whitfietri and are deroid of tubercles. The sutures were not rery clearly made out. The matrix has the aspect of an arenaceous? limestone, color light brown. The largest specimen from Fort Collins, Colo, is $155 \mathrm{~mm}$. and the smaller one from El Paso County, Colo., $84 \mathrm{~mm}$. in whole volution. One specinen in the collection of the Boston Society of Natmal History reaches 265 mm. in dianeter and has a concave rentral zone on both shell and east at end of onter volution. There are excessively faint tubercles along the umbilical shoulders but un traces of them on the erlges of the ventral zone, either on shell or cast.

The shell on this specimen and on several others is sufficiently perfeet to show that there are the following parts. An outer opaque probably porcellaneous part of several layers, next a middle part with more or less of luminons red coloration, also of several layers, and an inner part, also of several layers, with the usual iridescence of macrems shell

Two specimens from Lomp, Fork, Nebr., in the Museun of Comparative Zoology, show the typical large siphonal saddle with dependent marginal saddles of whitfietdi. One of them belongs to the parephebie stage of a shell having at the same time concave renter on both cast and shell with very faint tubercles, and the other and the two described next below represent the gerontic stage of a shell of very large size of the same species, with flattened venter on the cast and very faint concave zone on the shell. but no signs of tubercles on this part. The umbilical shoulders were destroyed. In both of these specimens from Kansas the rentral branches of first lateral saddles did not reach the edges of the renter and the same smooth band appeared on either side of this part as in other forms of this group. I can not at present separate them from whitfieldi upon the basis of their slight tubereulations, since faint tubereles are apt to be present at some stage even in typical forms of this species A fine specimen from Nebraska, diameter $228 \mathrm{~mm}$, and covered with beautiful nacre, shows cherron markings and has concave ventral zone and faint, 
rather uncertain indieations of tubercles that may have existed on the outer. shell, although the inner line on the umbilical shoulders is plainly shown on the nacre of the last volution. These last are obvionsly confined to this volution of the ephebic stage, since they are not present on the inner volutions, which are covered by the thick, opaque outer layer of the shell. This settles the finct that these tubereles may appear very late in the life of this species. They are small and wide apart on this specimen when the rolution from line of involution to the venter is $60 \mathrm{~mm}$., and are not present on the extemal shell in that part of the same volution which is about a centimeter apical across a break in the fossil. There are fine transverse wrinkles on the nacreous layer in the rentral zone of this shell.

A large, much crushed fossil from Loup Fork, Nebr., also collected by Dr. Sternberg, is $215 \mathrm{~mm}$. in diameter and has the external shell well preserved and as usual very thick, especially on the umbilical shoulders. Faint tubereles are present on the last rolution and are also preserved on a remnant of shell belonging to a volution which has been bioken away. Such small tubereles as these might be present on a shell and yet be absent on a cast.

A fine specimen in the National Insem, with nacreous layer, from southem Colorado, and having typical sutures of the western form and also identical in other respects, has a diameter of $136 \mathrm{~mm}$. and shows faint tubereles on the nacreous layer. The volution is $65 \mathrm{~mm}$. in dianeter from line of involution to venter, when the first tubercle appears. This specimen makes it possible to say definitely that these appear in the ephebic stage, probably metephebic substage.

One specimen, fiom Black Hills region, in the collection of the Boston Society of Natural History, shows faint tubercles on umbilical shoulders when the diameter is less than 100 mm., and there are faint but perfectly defined ninute tubercles on either side of the renter. Another specimen in the same collection and from the sanne locality has a dianeter of $305 \mathrm{~mm}$. It is without living ehamber and has the nacreons layer in part preserved. There are faint tubercles on the umbilical shoulders of the next inner and part of the outer rolution. The sides have three obseure broad longitudinal folds or ridges in the gerontic stage. There are no tubercles on the edges of the rentral zone. This zone continues to be rery faintly concave, even on the last part of the onter volution. The gerontic stage 
begins with a slight trinsverse constriction, after which the transserse dianeters increase considerably and the volution is stouter and larger.

'The larest specimen so far recorded is in the University Mnsem in New Haven (hocality, had Lands, South Dakota). This has been measmed by 1)r. C. E. Beecher, who also very comrteously sent me a sketch and notes on its characteristics. The dianeter of the entire fossil is $630 \mathrm{~mm}$. (24:3inches). The ventro-lorsal diameter of aperture from line of involution to venter is $300 \mathrm{~mm}$., and the transverse $150 \mathrm{~mm}$., showing how much the volution has broadened in this extreme gerontic stage. The first quarter of onter volution has a flat renter $8 \mathrm{~mm}$. wide, the edges rounded. The living chmmber is perfect and occupies one-half of a vohtion, showing no decrease in length as compared witl smaller specimens. There is, however, the usual decrease in the amount of involution of the whole of the outer volution. The venter loses its flatuess entirely on the second quarter' of the outer volution and on central parts of living chamber, becomes rounded, and the sides then hecome gibbous at a short distance inside the renter, as is not uncommon in old age. There is a tendency to resume the form of syrtale and of its own earlier stages. Near the aperture the gerontic flat zone noticed in other specimens returus upon the centran part of the renter, but the latter still remains rounded with the same gibbous ontline to the outer parts of the sides. 'The aperture, as described in other' specimens, has a short, broad rostrum and low, broad lateral crests.

Locality: Nebraska; South Inkota; Colorado.

Aye: Fort Pierre gromp, Upper Cretaceous.

Placenticeras whitfield variety tuberculatum Hyatt.

Pl. XIVII. fig. 5.

I have so far seen ouly three shells from Bad Lands, South Dakota, having a very faint line of median lateral tubercles both on cast and shell, as well as minnte denticles on the sides of the venter and tubercles on the mbilicul shomlders. The two onter rows disappear at the end of the neanie stage, when the shell is about $80 \mathrm{~mm}$. in diameter. These are obviously transitional to $P$. peudoplacentu, but lave much finer tuberculations and more complicated sutures.

Loculity: Barl Lands, Sonth Dakotis.

Age: Fort Prerre group, Upper Cretaceous. 


\title{
Placenticeras spillahani n. sp. Hyatt.
}

\author{
Pl. XLVII, figs. ti-s.
}

This species is founded upon a fragment, No.4, in the collection of the Acadeny of Sciences of Philadelphia; but this is so distinct from any species of Placenticeras known to me that I renture to describe it here. This was in same tray with three franments of Sphenorliscus labeled "Spillman Coll. Loc. Mississippi."

The estimated diameter of the volution is $80 \mathrm{~mm}$. ; the actual ventrodorsal dianeter measured along the exposed septum from dorsal lobe to ventral lobe is $48 \mathrm{~mm}$; and actual transverse diameter is abont $40 \mathrm{~mm}$. through the dorsal lobe. It has, therefore, a much stouter volution at the same age than its near allies, placentu or stantoni, and the venter is broad in proportion, being $9 \mathrm{~mm}$ in width, flat, and with low tubereles on either side about $14 \mathrm{~mm}$. apart. The fingment is only the "ast of the wuter parts of two living chambers, and whether there were intemal rows of tubercles conld not be determined, but the sides lave the flattened aspect of species that dn not habitually lave a median lateral row of tubereles. The sutures are closely similar to those of syrtale; they have broad, rather short, solid saddles, with short marginal saddles, the lobes narrow and broad, only at the apical ends. The outer part of the septum is more deeply concave than in placenta and the lobes and saddles are less complex in outline. There is a cast of one chamber in the collection of Yale University, said to be from Burlington, N. J., with a similar broad renter, that may be the young of this speries. The dorso-ventral diameter measured in same way as above is 24 mm1., and transverse diameter is about $18 \mathrm{~mm}$. There is also a cast from Ifusselshell Creek, Idaho, having a very broad venter. This belonged to a much older and larger shell with very different sutures.

Locality: Burlington, N. J.; Mississippi.

\section{Placenticeras ? telifer (Morton).}

Ammmitestelifer Morton, 1884, Synop. Organic Remains, pl. 2.

Ammonites (Placenticems) telifer Whitfield, 1892, Mon. U. S. Geol. Survey, Vol. XVIII, pl. 41.

After examining the fragments of this species in the collection of the Academy of Sciences, Philadelphia, I an unable to determine with 
certainty whether this is a species of this genns or not, and the details of the sutures, so far as my hasty examination went, were too imperfect to enable me to make a reasonable guess with regard to their affinities.

Loculity: New Jersey.

Age: Upper Cretaceons.

Placenticeras? faldax Castillo and Aguilera

Plucenticerus? fallax Castillo and Agruilera. 1595, Bol. Com, geol. de México, No. I, p. 17. pl. :.

This species is liere mentioned because it is likely to be quoted as a species of this genus, whereas both the remarks of the authors and the figures show that it should be quoted as probably not a member of this genus. The authors consider the sutures as placenticeran, but very rightly regard the form as more like that of Phylloceras. I have not as yet seen a specineu of this gentis that has such a rounded rolution even in the gerontic stage, and this Mexican specimen was ouly $104 \mathrm{~mm}$. in diameter.

Locality: Mexico.

Age: Lower Cretaceous?.

\section{Placenticeras ebrayi (de Loriol).}

Amalthense elrrayi de Loriol. 1882. Mém. Soc. Pal. Suisse. Vol. IX. Pl. I.

Placenticerns elnayi Kossmat. 1895. Beitr. Pal. und Geol. Oesterreich-Lngarn- und des Orients. Vol, IX, p. 170.

This figure shows a large and aged specimen of $250 \mathrm{~mm}$. in diameter. The anagerontic substage is given upon the first part of the outer volution, and during this time the venter remains flattened and has large alternating tubercles of the usmal elongated form on either side, but the edges of this zone are not sinnous. There are fold-like single costie appearing in this substage, and these are prominent, but have no tubercles if the riews are currect. These single folds are continned in the metagerontic substage when the rentral line of tubercles disappear and three lines of lateral tubercles appear for the first time on the coste. In the paragerontic substage these tubercles disappear, first the outer, then the inner lines, and then the central line. 'The folds also tend to disappear and the venter is seen to be completely rounded and smooth in this substage and the involution has become considerably diminished, judging from the aspect of the 
umbilicus. The gerontic tubereles, together with the ventral line of tubercles, make up four rows, one more than appears in any other shell of this genns. The sutures were observed only in the anagerontic substage, bnt they are distinctly separated and have obvionsly not lost their ephebic characters.

There may be but two secondary laterals derived from the primitive first lateral saddle, or there may loe three; one can not tell with exactitude from the drawings and descriptions. The general aspect of this shell is in faror of association with the species of Placenticeres, lut the extra line of tubercles in the old, the fold-like, almost straight costre, and the possibility that there are conly two secondary saddles, the first and second laterals, make the generic reference dombtful. The ontlines of these sutures remind one strongly of P. uathi Kossmat, and in this speeies there is also the same difficulty in making out whether the first lateral is single or double. The ventral lobe is deep and narrow, as in $P$. uhligi, but the siphonal saddle is small. The shell is apparently smooth in the ephebic stage, as in u'urthi, ete.

Age: Gault of Cosne.

\section{Placexticeras warthi Kossinat.}

Ammomites orbignyanns Stoliczka, 1866, Pal. Indica, Vol. I. pl. 45, fig. 2.

Placenticens wathi Kossmat, 1595. Beitr. Pal. und Geol. Oesterreich-Ungarus und des Orients, Vol. IX, pl. 20, tig. s.

This species is, as stated by Kossmat, quite distinet either from orbigmyames of Geinitz, or syrtulis, var. orbigmyame of Schliiter. Kossmat's text clearly states these distinctions, but he gives both of these names in his synonymy as in part belonging to this species, and on this fact we differ. The yomig as figured in section by Stoliczka has a rery hroad renter in the ananemic substage and the broad venter is retained throughout the neanic stage.

The sutures are exceptional, the rentral saddle distinct from any other species of this genus, and there are so slight differences between the principal lateral saddles and the anxiliaries that one can not, aceording to Kossmat's figures, draw a definite line between the auxiliaries and the prineipal saddles. Kossmat counts the two arus of the first lateral as two saddles, but describes these as having arisen from division of the first 
lateral, and lis figure shows this. He consequently considers the species as having four principal lateral saddles, whereas they should be comnted as three. Stoliczka's figure of the older specinen in his Fossil Cephalopoda of Cretaceous Rocks of Southern India also shows distinctly the three principal saddles. Kossmat considers this identical with the American I'. syrtale, but, as has been noted elsewhere, I'. tammlicum, and especially schlüteri, are more like the former. The absence of all except the ventral line of tubercles and the broad, fold-like costre, broad renter, and stont whols are as peculiar as the sutures in rarthi. In the ragged aspect of the sutures and broad, flat renter, this species has some resemblance to $I$. stantoni of the Colorado gromp. This farors the view that this species occurs in India somewhat earlier (in the lower Utatur group, which is placed by Kossmat in the Cenomanian) than its representative in this country. This evidence is in faror of the riew stated by Stanton and other's that the Colorado is the equivalent of the Turonian.

Age: Cenomanian.

Placenticeras memoria-schloenbachi Lambe and Bruder.

Placenticerus memeriut-schloenbachi Laube and Bruder, 1857. Palarontogr\%. Vol. XXXIII, pl. 23.

This species has a diameter of $198 \mathrm{~mm}$; it is smooth with the exception of a single imner row of small tubercles on the umbilical shoulder. The umbilical zone is well shown in figure, and the ventral zone very narrow and smooth on the cast. The parts of two sutures shown have very simple outlines and are wide apart even in what is evidently the parephebic or anagerontic stage of this species.

The outlines are probably more or less worn and have lost their digitations in part, but could not in any event probably have been as closely approximated as in species like placente or whitficldi. Laube and Bruder consider that the sutures are similar to those of Placenticcras requieniamum (d'Orbigny, Terr. Jurass, pl. 93, fig. 4), but this species does not belong to this genus.

Age: Turonian. 


\section{Placenticeras depressum n. sp. Hyatt.}

Placenticerus syrtule Grossourre (pars), 1893. Ammonites ('raie supérienre, p. 128,

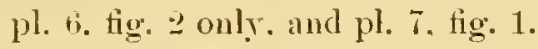

Ammenites syrtalis Schlüter (pars), 1871, Palarontogr., Vol, XXI, pl. 1t. figs. 9 and 10 only.

This French and German species is undoubtedly a rery close ally of guadulupe and is called variety guadalume by both authors, who suppose it to be identical with the American species of the same name. The latter, however, has not the costre in the young shown in the mubilicus as figmed by Grossouve on pl. 7, and the immer nodes in the American form are on the umbilical shoulder at all stages, the umbilici heing deeper and the volution thicker or stouter in proportion This species also includes Grossouve's vilriety quadratum. The saddles are more deeply undereut and outlines of both lobes and saddles more eomplex. They are, however, rery closely representative species. Schliiter's figne shows the impression of a keel in the inpuressed zone of the fragnenst of an onter volution, but this is probably either arcidental or a mistake in the figure, jurlging from the description. The obvious excellence of Grosionve's work and figures enables one to see clenly the relations of these forms, and he describes them as varieties. Wre differ simply in our estimate of their relative inportance, he prefering to call them varieties, and I to name them as distinet species in accorlance with the methods adopted in this and other papers.

Age: Lower Senonian (Simtonian).

\section{Placenticeras grossouvrei 11. Ap. Hyatt.}

Placenticeras syrtale (pars) Grossourre, 189:. Annonites Craie supérieure, pl. 5, fig. 3 ; ; 1. 16. fig. 1 (no others).

The French form has no corresponding representative now known m this country. 'The young, if it be the young, figured on pl. 5 , is costated like the gerontic stage of polyopsis of Dujardin, but it also has a prominent, closely set row of tubercles on either side of the narrow concave venter. The large fossil figured on pl. 6 has an umbilicus so very different that if it belonged to almost any other genus ome would say at once it could not be the same. In this genus, however, the young are so compressed and distinct that no safe inference (an be made from figures alone. This 
specimen is certainly in the gerontic stage, with the merlian lateral row of tubercles alreatly on the borders of the venter. The ventral rows shown in fig. 3 of pl. 5 hare disappeared entirely, and the venter is smooth and flat and very broat, the tubercles nearly opposite. 'The imner row of nodes begins to recede from the line of involution very early and gradually approximates to the outer row. On the last quarter these tubereles again begin to approach the umbilical shonlders, increasing their distance from the outer line--a movement not paralleler in any American form I have as ret seen.

Aye: Lower Senonian (Santonian).

Placenticeras incisum n. sp. Hyatt.

Pluenticeress syrtule (pars) Grossonvre, 1843, Ammonites Craie supérienre. pl. 8, fig. 1 (no others).

In this form the volution is described and figured as compressed and smooth until a late stage. The specimen is in the parephebic substage on the first quarter of the outer volution; i. e., the median lateral line of tubereles is close to the ventral line. The venter is, however, still concave, narrow, and tuberculated. On the second quarter the venter broadens to these lines of tubercles, the ventral ones disappear, the imer line of large norles appears first at the center of the lateral zones and rapilly approximates to the outer lines, being joined to them by costre. There are only five of these nodes, and while the third and fouth are nearest to the venter, the fifth is set somewhat farther away inwardly, thus mdieating, as in grossowrei, the sime tendency of the noles to return inwarlly in extreme age. The peculiar hroal, concave venter of the paragerontic sulstage is also akin to the aspect of the renter in an earlier substage in grossoncrei, but is a great exaggeration of this tenden'y, and wceurs after the venter has become convex in the anagerontic substage, as is shown on the lower outline of fig. 1b. These fignres are so fine that these ubservations are made upon their anthority, and show a great difference between these and related American firms.

Gussureses reference of this variety to $I$. milleri of Haner allows mure latitule for variation than is given in this memoir. Milleri has conly one row of tuberwes, and the form of the renter is distinct.

Agr: Senmian, 


\section{Placenticeras mlleki (Hauer).}

Ammonites milleri Haner, 1stb, sitzmgsber. K. Akad. Wiss., Wien, LAll, p. 3nt. pl. 2.

This species from Steirmark is quite distinct from any ut the French forms describer by Grossonre, but it may be identical with some of the German forms already described having but one row of tubercles in an advanced stage of development. It lias smooth sides, with only one row of tubercles on the onter volution, and apparently also in the earlier stages, as figured and described by Haner. As stated by that author, it is very like lidorsatus, except that it has a couvex and morlerately broad venter. This last character also, as well as the peculiar form of the nodes on the edges of the venter and absence of inner lines of tubercles, separates it from Grossonve's species. Haner had specimens from 2 to $3 \frac{1}{2}$ inches in diameter. Age: Senonian.

Placenticeras schlëteri h. sp. Hyatt.

Ammonites syrtulis var, polyops is shlüter, 1872, Palacontogr.. Vol. XXI, pl. 14. tigs. 1-?.

This species las ornaments rery similar to those of polyopsis Dujardin, but these are quite distinct and peculiar in their ontogeny. The ephebic stage has two lows of large lateral tubercles, as well as ventral rows, and accorling to Schliiter's figures and descriptions the inner row in the anagerontic substage recedes outwarlly, becoming approxinate to the second outer row. The renter at the same time changes, becoming rounded and broader, but the rentral tubercles are still present. These figures are sinilar to the American syrtule, but differ in being less involute and in the wider removal of the imer row of tubercles from the umbilical shonlders and the elliptical section of the gerontic stage. In syrtale this section is distinctly subtriangular and nore compressed in the sane metagerontic substage.

Age: Lower Śenonian. 


\section{Placenticeras orbignyanum (Geinitz).}

Ammonitres vibrayermes Geinitz, 1843, Verst. r. Kieslingwalde, Pl. I. fig. 8. Ammmites orlignumus (reinitz. 1850, Quadersand. in Deutschl.. ph. 14.

Ammonites ontimyanus Drescher, 186\%, Zeitschr. Deutsch. geol. Gesell., Vol. XV,

tig. 8 .

Ammonites orbigmyamus Fritsch and schlönbach, 1872, Ceph. böhm. Kreide, pl. 10, figs. $4,5$.

Ammonites mbrignyumes Geinitz. 1875, Elbthalgeb. in siuchsen, pl. 36.

Pacent. fritschi Grossonve, 1898, Ammonites Craie supérome, pl. 5, tigs. 1, 2.

This species has fold-like costre and broad renters in the young, as figured by Fritsch and Schlöubach and by Geinitz in his Quadersandsteingebirge. One can not say anything definitely from the figure given in the first publication under name of vibrayeams. The figure in Elbthalgebirge also appears to be the young of this same species; consequently Dreseher's figure of the suture quoted above must also belong to this species and serves to correct the conventional figure given in Quadersandsteingebirge. There are three principal saddles, is in other species of this genus.

Grossouve's figures are excellent and give elear ideas of this species. The broad, smootl, convex venter of what is probably the gerontic stage, and the young, both having costce like the figures in the Quadersandsteingebirge, appen to show that the French and German forms are identical. The sutures as figured are different, but this may be due to the poor drafting of the figures in the Quadersandsteingebirge and in the Zeitschuift by Drescher.

Age: Lower Senonian.

\section{Placenticeras pólyopsis (Dujardiu).}

Ammomites polyopsis Dujardin, 183i, Mém. Soc. géol. France, No. ㄹ, pl. 4.

'This species has a form similar to pseudortigmyanum, lunt only in old age, the ephelic stage being smootl. The flattening of the renter in the gerontic stage is a transformation that may ocenr in any species of this and other genera at the same age and can not be considered to indicate specific identity. The ornaments are altogether different. The tubercles of the outer row are more or less connected with the inner low by indistinet, nore or less bifureated, costa, and the inner row does not change place with age. The ventral tubercles are larger and more widely separated than in 
schluteri, and all the tubercles and costa orem only in old age, aconeling to the figures. whereas in the latter they are present in adults as well as in the gerontic stage,

Age: Lower Senonian.

Placenticeras crassatum n. sp. Hyatt.

Ammonites syrtalis var. obligmyun schlüter (pars), 187\%. Palaontogr., Vol. XXI. pl. 14, figs. t-i. fig. 3! (no others).

This species differs from schliteri, being' more conpressed. The recession outwardly on the inner row of tubercles does not take place. The imer row of tubereles disappears in what is probably the anagerontic substage, and in this also fold-like costic are developed. The venter remains flattened, the sides flat, and the ventral tubercles are still well developer in this substage.

Age: Lower Senonian.

\section{Placenticeras tamilicum (Blanford).}

Ammonites tamenticns Blanford, 1563, Mem. Geol Surr. India, Vol. IV, p. 118.

Ammemites gundalnpe Stoliczka, 1866. Pal. Indica, Tol. I, pl. t7, and pl. t8, tig. 1. Placenticems tummlionm Konsmat, 1s95. Beitr. Pal. und Geol. Oesterreich-Lngarns und des Urients. Tol. IX, pl. 2ㅡ, figs. 1 a-c.

The neanie stage of this Indian species is figmerl by Kussmat, and this, together with the figures by Stoliczka, shows that this shell had a more compressed form, Hatter sides, narrower ventral zone, and different sutures in the adult and less prominent and less distinct costations than the gibbous-sided form, also inchded in this species by Stoliczka in Paleontologia Indica and figured, pl. 47, fig. 2, sutures being also given, fig. 2a. 'There are considerable variations in the shapes of the saddles, between the last figure and those of tamulicum (guadulupe) on pl. 48, fig. I, which can lardly be aceounted for by differences of age in the specimens. It is difticult of course to say to which of the two forms the large specimen on pl. 47, fig. 1, may belong, and any attempt to separate them under different names would not be advisable. This last figure, $183 \mathrm{~mm}$. in diameter, is in the gerontic stage and shows a second external row of nodes of large size and the inner row increasing greatly in size to blunt norles on the last part of this volution. None of these authors mentions any rounding-off of MOX XLIV-03-16 
the venter in old age, and apparently the venter retains its ephebic character's in this oll specimen. I can not join Kossmat in considering syrtule of Schliiter as irlentical with this species. The American syrtule shows old age at a smaller size than in tomulicum, and the nodes and spines are much larger and last longer, especially the median lateral row, but it is much closer to this species than to any other Furopean form except schlüteri. The more connressed form of pl. 48 las the external characters of the Anerican lenticulare as figured by Meek, but the sutures are quite distinct. Aye: Lower Śnonian.

\section{Placenticeras pseudorbignyanum 11. sp. Hyatt.}

Ammemites syrtulis var. whignyumus Schlüter (pars), 1S71, Paleontogr., Vol. XXI, pl. 15. figs. :3-5, no others.

Schliiter's figure of a typical example of orbignyanus is not similar to that of Fritsch and Schloenbach, nor to Geinitz's species, nor does it agree with lis val. orbignyames given on pl. 14 . It is a very distinct shell, having but me nedian lateral row of tubercles in the neanic stage. It is otherwise smooth and witl nalrow ventral zone.

Age: Lower Senonian.

\section{P'LACENTICERAs? subTilistriatun Jimbo.}

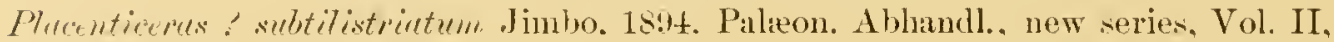
pt. $\because$ pl. 1, figs. 1, 1 .

This is merely mentioned liere to call attention to the distribution of the genus. It is figured as a roung, compressert shell and is certainly in aspect like a species of this genus. The figure has a centran trace or keel on the venter, although this part is described as being sinply convex.

\section{DIPLACNOCERAS a Hyatt.}

This gemus resembles Engonoceras quite elosely in its involute compresserl volutions and chamneled venter bordered by continuous ridges, and in the tuberculation of the sides it is sufticiently near to be included in that genus if the sutures were unknown. 'These are, however, well known, thankis to Schliiter's fine figures, and they appear to be similar to those of 
Placenticeras. This genus therefore combines the external characters of Engonoceratide with the sutural lines of Placenticeratide, and perhaps onght to be placed in a separate family.

'The yomng, howerel, are unknown, and it is perhaps better to wait until their development places their aftinities on a firmer basis. It is also possible that they may be accounted for as members of the Placenticeratida that were arrested in their development, retaining the neanic condition of the venter and lateral zones in their latel stages, but not arrester in their sutues, which approxinate to those of Placenticeras.

\section{Diplacioceras bivorsatey (Romer).}

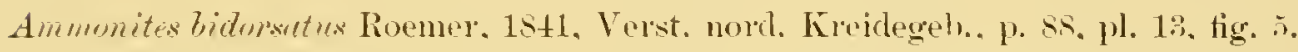

'This species has an outer row of lateral tubercles, according to Roemer's figures, with an inmer row of tolds w coste directed apricad. The onter row of lateral tubercles are elongated continuations of the costre and are bent mad, forming crest-like mucreles ncar and parallel to the edges of the renter. This last is a concare zone, bordered by two continnous ridges without tubercles. The onter volution is deciderlly compressed, but is rather stout in proportion to its dorso-ventral diameter'. This species is obriously, mless both the figmes and rescription are eloneous, quite distinct from the bidorsutum of Schliiter, in having stonter rolutions and broaler venter and in the inner lines of narrow folds. There is, however, consiterable resemblance between the two, and it is mulncky that Roemer did not figure the sutures.

Age: Lower Senonian.

1)IPLaChoceras CaNalieulatim 11. Sp. Hyatt.

Ammemites polyops is Schlüter, 1stī, Ammoneen norddeutsch. Senon., pl. 4.

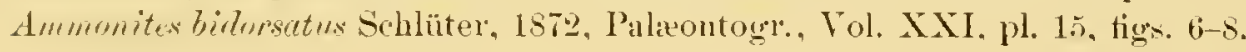

This species is very peculiar, having a well-tlefined gerontic stage with a row of lateral tubercles set well out near the venter and becoming nodose or prominent. The shell in the ephebic stage is smooth and compressed, the renter is extremely narrow and chumeled, and there are

(2) These are in no way comparable with ventral lines of tubercles as they uccur in Placenticerus, being on the -ides and near, but not on, the eriges of the venter. 
smonth continums ridges on either side that can be compared with those of Engonoceratidx. The differences between the shell figured by Sehliiter and the bidorsatum of Roemer are so well shown in the drawing given by the latter that there can be but little donbt they are different species. The sutures are not distinct generieally from those of Placenticeras, and wonld place the species in that genus if the characters of the shell were not so different.

Lorality: Westphalia.

Age: Lower Senonian.

\section{Incertæ sedis.}

STYRACOCERAS ${ }^{a}$ 11. gen. Hyatt.

Ammonites balduri of Keyserling, the type and only known species of this genus, can not be associated with any species known to have same number of principal lateral saddles, becanse the external characters differ from those of any species known to me. The resemblances in the sutures are certainly eloser to I'latylenticeras heteropleurum than to any other species, if Keyserling's drawings and Nenmayr's observations are correct. The suture has two broad prineipal lateral saddles, the first and second, or else these may be reekoned, as in others of this gronp, as one saddle divided into two branches. Until the young are known, this can not be definitely decider. (See Platylenticeras.)

\section{Styracockrat halduri (Keyserling).}

Ammonites baldm.; Keyserling. 1st6. Petschora-Land. pl. 19, fig. ?.

The young, as figmed by Keyserling, hats a channel on the venter in the neanic stage after passing through a substage with an acute renter. This figure may have been taken from a partly crushed fossil. So far as known, the replacenent of an acute condition of the venter by a furrow is exceptional and requires more proof than a single drawing. Nenmayr obtained the miginals of Keyserling's deseription and stndied them, but his attention was not apparently attracted to this fact, and he did not break down any of the fossils to investigate the young. He redescribed, but, muluckily, did not have them redrawn, and did not state whether the 
smallest fossil, about $10 \mathrm{~mm}$. in diameter, was exactly represented in Keyserling's figme whieh shows the acute venter. Neumayr" "loes, however, state clearly that the venter becomes furrowerd at $15 \mathrm{~mm}$. in cliameter, and that this furrow is snceeeded by a stage with a rounded renter which preceded the incoming of a stage with a slightly convex venter and distinct ventro-literal angles, and that this precedes a stage with distinet keel developed upon the elevated venter, and tubercles developed upon the costre intemally and at their terminations on the ventro-lateral angles. Such an extraordinary suecession of transformations is irreconcilable with those of the ontogeny of any group known to the anthor. The resemblanees of the sutures are, therefore, not sufficient to place the genus in the same group with Platylenticeras, from which it differs in every other respect.

Neumayr's view of the affinities of this genus for the Amaltheidxe is not sustained by anything except the general similarity of the external aspect of adults, which is probahly due to parallelism, and the sime is true of its supposed aftinities for C'ardioceras. The characteristies of form and ornamentation supposed to be so similar have obrionsly arisen from entirely distinct modes of development, and these genera are not even as closely related to each other as to Styracoceras.

Age: Neocomian.

a Ueber Amalth. halduri Keyserl. u. u. Gattung Carlioceras. Neues Jahrb. für Min., Cieol., and Pal., 1886, 1, w. 95. 


\section{BIBLIOGRAPHY.}

Barte. E., and H. Coquand. Némoire sur les fossiles necondaires recneillis dans le Chili par. M. I. Domeyko et sur les terrains auxquels ils appartiennent: Mém. Soe. géol. France, ¿d series, Vol. IV. 1851.

Bayle, E.. and R. Zenleer. Explieation de la Carte géologique de la France, Vol. IV, Atlas. Paris, 18 os.

Buxскнов'т, J. J. T. vax. Mlonographie des Gastéropodes et des Céphalopodes de la Craie suṕrieure du Limbourg. Brossels and Leipzig. 1873.

Blaxfom, H. F. Cretaceon- rocks of the South Arcot and Trichinopoly districts: Mem. Geol. Surr. India, Vol. IV. Pt. I. $1 \$ 63$.

Bönı. J. Ueber Anmonites pedemalis v. Buch: Zeitsehr. Dentsch. geol. Gesellschaft, Tol. L, pp. 183-201. 15:4s.

Brcn, L. vox. Ueher Ceratiten: Ahandl. K. Akad. Wiss, zu Berlin, 18ts. pp. 1 -31e. 1850.

Buckuax. S. S. A monograph on the Inferior Oolite ammonites of the British Islands. Palientographical Society. 188i-1sit.

Castrllo, Axtoxio del, and Jose G. Aguilera. Faluma fósil de la sierra de Catoree, San Lni Potosi: Boletín de la Comisión geológica de México, No. 1. 15.95 .

Cinoffat. Palto Reeneil d'études paléontologiques sur la fame crétacique du Portugal. Vol. I. Esprees nouvelles on pun conmes. ed series. Les Ammonées de Bellasien, des conches à Néolobites Vibrayeanus du Turonien et du Sénonian. Lishon, $1 \mathrm{~s}: \mathrm{s}$.

Conran, T. 1. Descuption of the fossils of Syria collected in the Palestine expedition: Lynch. Otticial Rept. of the C. S. Expl. to explore the Dead sea and the River olordan. P1. 211-235. Baltimore. 1852.

Description of (Cretaceons and Tertiary fossils: Rept. U. S. and Mexican lwundary survey (Enory). Vol. I, l't. II, pp. 141-1+3, 14i-1it. Wishington. $1 \times 5$.

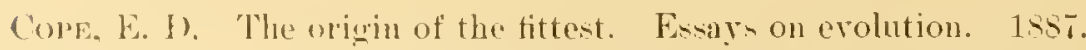

Crans. F. W. A contribution to the invertebrate paleontology of the Texas Cre. tacono: Fonrth Amn. Rept. Geol. Survey of Texas, Pt. II. pp. 1+1-2nt. Anstin, 1s:13.

Now and little known vertehrates from the Neocomm of Kansas: Aneriean

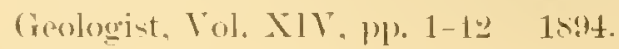

$2+15$ 
Cragin, F. W. Buchieeras (Sphenodiscus) belviderensis and its varieties: Colorado College Studies, Vol. VIII, pp, 27-31. 1900.

Dekar. I. E. Report on several fossil multilocular shells from the State of Dela- ware, with obserrations on a second specimen of the new fossil genus Eurypterus: Ann. New York Lyceum Nat. Hist., Vol. II, pp. 273-279. New York, $18: 8$.

Douvillé, H. Sur la classification des Cératites de la Craie: Bull. Soc. géol. Fraure, 3d series. Tol. XVIII. pp. $275-292.1890$.

Sur le Tissotia tissoti: Bull. Soc. géol. France, 3d series, Vol. XIX. pp. 499-503. Paris, 1891.

Drescher, R Ueber die Kreide-Bildungen der Gegend ron Lömenherg: Zeitsehn. Deutsch. geol. Gesell., Vol. XV. pp. 291-366. 1563.

Dujardn. Frizix. Sur les conches du sol en Touraine et deseription des copuilles de la Craie et des Falons: Mém. Soc. géol. Framee. 1st series. Vol. II, pp. „11315.1837 .

DuNker. W. Ceber Ammonites gervilianus d'Orbigny aus dem norddentschen Flilsthone: Palwontographica, Vol. I. pp. 324, 325. 1551.

Fallot, l. Étude géologiqne sur les étages moyens et supérieurs du terrain Crétacé du sud-est de la France: Amules des sciences géologiques, Vol. XVIII. 1855.

Fracinz. Patz. Manuel de Conchỵliologie et de Paléontologie conchyliologinute. Purlis, 1887.

Fonbes. E. Report on the fossil invertebrata from sonthern India: 'Trans. Geol. Soc. Lond., 2d series, Vol. VII. pp. $17-17$ t. London. 1 st5.

Fritsch, A. and U. Schlösbacil. Cephalopoden der höhmischen Kreideformation. Prag. 18\%.

Gabb, W. M. Description of Cretaceous fossils from Mexico: California Geological Surver. Paleontology of California, Vol. II, pp. 255-276. 1869.

Deseription of a collection of fosils made hy Dr. Rainondi in Per'u : .Iour.

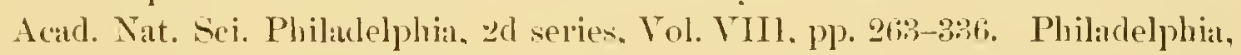

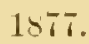

Gemstz, H. B. Das Quidersandsteingebirge oder Kreidegebirge in Deutschland. Freiburg, 1550 .

- Das Elbthalgebirge in Sachen: Palrontographica. Vol. XX. Cinsel. $1871-1875$.

Die Versteinerungen ron Kieslingswalda im Glatzischen. und Nachtrag zur Characteristik des siichsiseh-böhnischen Kreidegehirges. Dreschen and Leipzig. 1 st3.

Gernalid, K. Beitrag zur Kenntniss der Kreideformation in Veneznela und Peru.-Beitrag zur Kemntniss der Kreideformation in Columbien: Nenes

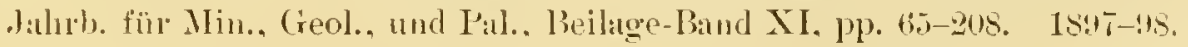


Grossouvre, A. ne. Les Ammonites de la Craie supérieure: Mém. pour servir à l'explication de la carte géol. détaillée de la France. Paris, 1893.

Haulin, Cunrles E. Results of an eximination of syrian mollusean fossils, chiefly from the lange of Mount Lebanon: Mem. Mus. Comp. Zoology, Vol. X. No. 3, pp. 1-68. 1884.

Hauer. F. vox. Neue Cephalopoden aus den Gosaugebilden der Alpen: Sitzungsib.

K. Akad. Wiss., Wien, Vol. LII, Abth. I, pp. 300-30s. 1866.

Inrmite. H. Études géologriques sur les lles Baléares (Majorque et Minorque). Paris, 1879.

Hratr, A. Report on the Cretaceons fossils from Maroim: Geology and Physieal Geography of Brazil, by C. F. Hartt, pp. 385-393. 13oston, 1870.

The Inrassic and Cretaceous Ammonites collected in South America by Prof. James Orton, with an appendix upon the Cretaceous Ammonites of Prof. Hartt's collection: Proc. Boston Soc. Nat. Hist., Vol. XVII, pp. 365-378. 1875.

Bioplastology and related branehes of biologie researeh: Proe. Boston Soe. Nat. Hist., Vol. XXVI, pp. 59-125. 1893.

Cephalopoda. 'Text-book of Palcontology, by Karl A. von Zittel. Vol. I. Pt. II, pp. 502-592. London and New York, 1900.

Innвo, K. Beitrïge zur Kenntniss der Fauna der Kreideformation ron Hokkaido: Palicont. Abbandl. heransg. von Dames u. Kayser, new series, Vol. II, Pt. II. Jena, 1894.

Ferserusg, A. Wissentehaftliche Beobachtungen auf einer Reise in das Petschora-Land im Jahre 1st?. St. Petersburg, $18+6$.

Kossmat, Fraxz. Untersuchungen über die südindische Kreideformation: Beitr. Pal. Geol. Oesterreich-Ungarns und des Orients, Vol. IX. Pts. III und IV: Tol. XI, Pts. I and III. 1895-1897.

Laube, C. C., and G. Bauder. Ammoniten der böhmischen Kreide: Palrontographica, Vol. XXXIII, pls. 4-6. Stuttgart, 1887.

Lomol. P. De. Études sur la faune des couches du Gault de Cosne: Mém. Soc. Pal. Suisse, Vol. IX. 1892.

Mnek, F. B. A report on the invertebrate Cretaceous and Tertiary fossils of the Upper Missouri country: Mon. U. S. Geol. Surv. Terr., Vol. IX. Washington, 1876 .

Jorton, S. G. Synopsis of the organic remains of the Cretaceous group of the United States. Philadelphia, 1834.

Neunarri, M. Die Ammoniten der Kreide und die Systematik der Ammonitiden: Zeitsehr. Deutseh. geol. Gesell., Vol. XXV11, pp. 854-14. 1875.

Ueher Kreideammoniten: Sitzungsber. K. Akad. Wiss., Wien, Vol. LXXI, pp. 639-693. 1875.

Neumark, M., and V. Unug. Ueber Anmoniten ans den Hilsbildungen Norddeutschlands: Palæontographica, Vol. XXVII, pp. 129-203. Cassel, 1881.

NickLès, R. Contributions à la paléontologie du sud-est de l'Espagne: Mém. Soc. géol. France, Paléontologie, No. t. 1\$:90-1894. 
Noetura, Fritz. Fanna of the Lpper ('retaceons (Maistriehtien) heds of the Mari Hills: Pal. Indica, Ser. XVI, Fanua of Báluchistan, Vol. 1, pt. 3. C'aleutta, 1997.

Oppes. A. Palaeontologische Mittheilungen ans dem Musenm des Baierischen Staates. Stutgart, 1860-1 \$865.

D Orbigry. A. Paléontologie française: Deseription des animanx invertélrés. Terrain Crétacé. Vol. I. Céphałopodes. Paris, 1sto, 1st1.

Voyage dans l'Amérique méridionale. Vol. IHI, Pt. IV, Palléontologie. 1S42.

- Prodrome de Paléontologie stratigraphique universelle des animanx mollusques et rayonnés. Paris, 1850-185\%.

Owrx. D. D. Description of new and imperfectly known genera and species of oroanic remains, collected during the geological surveys of Wisconsin. Iowa, and Minnesot: : Report of a greological survey of Wisconsin, Iowa, and Minnexota, and incidentally a portion of Nebraska Territory, pp. 571-587. Philadelphia, 155․

Perox. 1. Exploration seientifique de la Tunisie: Deseription des Mollusques fossiles des terrains Crétacés de la région sud des hauts-plateanx de la Tunisie. Paris, 1s90, 1891.

L_- Les Ammonites du Crétacé supériem de l’Algérie: Mém. Soe. gréol. France, Paléontologie, Vols. VI and VII, No. 17. 18!17, $18: 17$.

Pictet, F. J., and G. Camprene. Description des fossiles du terrain Crétacé des environs de Sainte-Croix. Materiaux pour la paléontologie Suisse, Ser. II-VI. $1858-1872$.

Guexstedt, F. A. Die Ammoniten des sehwäbischen olura. Stuttgart, 18sis-1s8s.

Redtexbacher, A. Die Cephalopodenfama del Gosauschichten in den nordöstlichen Alpen: Abhandl. K. K. geol. Reichsanstalt, Vol. V, pp. 91-140. Wien, 1873.

Roemer. Ferdinand. Die Kreidebildungen ron Texas und ihre organischen Einschlïsse. Bonn, 1852.

Rocuer, F. A. Die Versteinerungen des norddentsehen Kreidegebirges. Hannover, $18+1$.

SAYx, G. Description des Ammonitides du Barrémien du Djebel-Ouach (près Constantine). Annales de la Société d'agrieulture de Lyon, 6th series, Vol. III, pp. 135-208. 1890.

Sowerby, J. Mineral conchology of Great Britain. 1812-1830.

SCHLËter, C. Beitragr zur Kenntniss der jüngsten Ammoneen a. d. norddentschen Senon. Bonn, 1867 .

Cephalopoden der oberen deutschen Kr reide: Paleontographica, Vol. XXI, XXIV. Cassel, 1871-1876.

Surarpe, Daxief. Deseription of the fossil remains of Mollusea found in the Chalk of England. Palrontographical Society, 1853-1856.

Shuyard, B. F. Descriptions of new Cretaceous fossils from Texas: Trans. St. Lonis Acad. Sci., Vol. I, pp. 590-610. 1859. 
Smith. .Janes Prinix. The derelopment and phylogeny of Placenticeras: Proc. Cal. Acad. Sci. ad series. Geology, Vol. 1. No. 7, pp. 181-240. San Francisco, $190 \%$.

Srastox, T. W. The Colorado formation and its invertebrate fauna: Bull. U.S. Geol. Anrey No. 106. Washington, 18:4.

Stensuan, (i. Tithon und Kreide in den peruanischen Anden: Nenes Jahrh. für Min., Greol., und Pal., 1881, Yol. II, jp. 131-153. 18 s1.

Stoluczia, F. and H. F. Blanford. Foswil Cephalopoda of the Cretaceou. Rockin of southern India: Mem. Geol. Surr. India. Palrontologia Indica, Series I and III. $1861-1866$.

STruckuax. C. Dic Grenzschichten zwischen Hilsthon und Wealden hei Borsinghansen an Deister: Jahrb. K. Preuss. geol. Landesanstalt und Bergakademic. pt. 3, pp. 55-79. Berlin. $158 \%$.

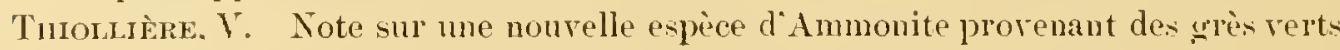
supérieurs du département de la Drôme: Ann. Soc. d’Agrieulture de Lron. 1st scries. Vol. XI. 184 .

Tuoner, M. Description of some new fossils from the Cretaceons rocks of the Southern States: Proc. Acad. Nat. Sci. Philadelphia, Vol. VII. pp. 16i-1i2. Pliiladelphia, 1856.

Uimbra, Y. Die Cephalopoden der Wernsdorfer Schichten: Denkschr. K. Akad. Wiss. Wien, Vol. XLVI. 1883.

Ceber die Cephalopodenfama der teschener und grodisebter Schichten: Denkschr. K. Akad. Wiss., Wien, Vol. LXXI1. 1901.

White, Cnaples A. Report upon the invertehrate fossils collected in portion of Nerada, Utah, Colorado, New Mexico. and Arizona. by parties of the expeditions of 1871, 1872, 1873, and 1874: U. S. Geog. and Geol. Surr. Wr of the One hundredth Meridian. Vol. IV. Paleontology. pt. 1. Wahington. $18 \pi$.

Contribution to the Paleontology of Brazil; comprining descriptions of Cretaceons invertebrate fossils, mainly from the provinces of sergipe. Permanbuco, Pará, and Bahia: Arehiros do Musen Nacional do Rio de .Ianeiro. Vol. VII. 1sss.

Wintfield, R. P. Gasteropoda and Cephalopoda of the Raritan clays and Greensand marls of New .Jerwey: Mon. C. S. Geol. Survey. Vol. XYIIl. Wawington. 1592.

Zittra. Kanl A. vox. Handhuch der Palaontologie. Abtheil. I. Palieozoologie. Bd. IJ. 1s81-1s85. 


$$
\text { PLA TES. }
$$



PLATE I. 


\section{P L A T E I.}

\section{Mojsisovichia. Buchiceras. Roemeroceras.}

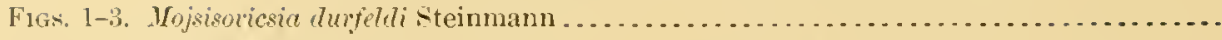

Specimeus from Pariatamlo, Peru; Albian? (after Steinmann).

Figs. 4-9. Buhiceras bilobutum Hyatt .

Figs. 4, 5. Natural size.

6. Enlarged, showing costre and aspect of center.

7. Front view of center of fig. 6 .

8. Suture from outer volution, part broken off in fig. $6, \times 3$.

9. Suture of young $\times 10$ when the costce begin to appear.

Cachiyacu, Peru; ["pper Cretaceous; my collection.

Figs. 10-14. Rom moreras syriaciforme Hyatt.

Fig. 10. Aged specimen.

11. Suture of same.

12. Younger stage of another specimen, all natural size.

13. Suture of same, right sirle, $\times 3$.

14. Suture of sane, left sile, $\times 3$.

Cajamarca, Peru; Ipper (retaceous: my collection.

Fig. 15. Roemerocerns altenuatum (Hyatt)

Fig. 15. Suture, natural size. The second lateral waddle has, by an oversight on the author's part, been drawn too deciledly as trifid. It is really a bifid hase with a prominent onter marginal and much like the same sadtle in fig. 13.

Celendin, Peru; Uprer Cretaceons; my coilection. 


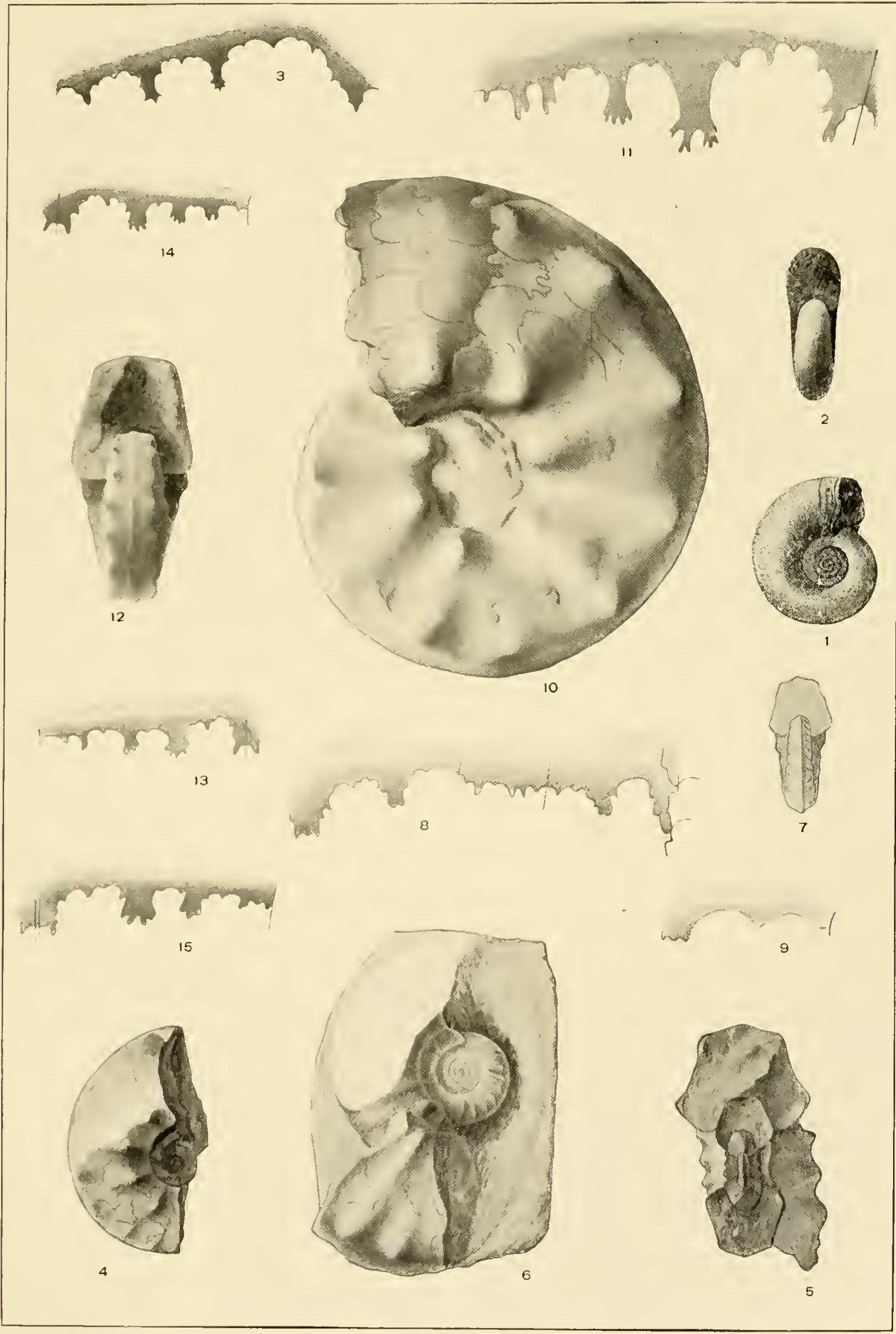

MOJSISOVICSIA, BUCHICERAS, ROEMEROCERAS. 

PLATE II. 


\section{P L A T E I I.}

\section{Roeyeroceras, Paratissotia.}

Flis. 1-3. Roemeroremes gabdi Hyatt

Fiuss. 1, 2. Natural size.

3. Enlarged suture. Coll. Acad, Nat. Sci. Philatelphia.

Qquebrada le Colpamayo, Peru; ['pluer Cretaceons; all after Galul.

FItis. 4-ij. Loemeroenes subylanmm Hyatt

Figs. 4. 5. Natural size.

6. Snture, $\times 2$.

Cajamarea, Peru; Upper Cretaceous; my collection.

F1cis. 7-11. Peratissotir serrutu (Hyatt)

Figs. 7 , 8. Natural size.

9. Fiyr. 8 enlarget.

10. Center of fig. 8 enlarged to show section of young and solicl keel.

11. Lateral and dorsal suture of fig. $T$ above the break.

Cachiyacu, Peru; Upper Cretaceous (Senonian?); my collection. 


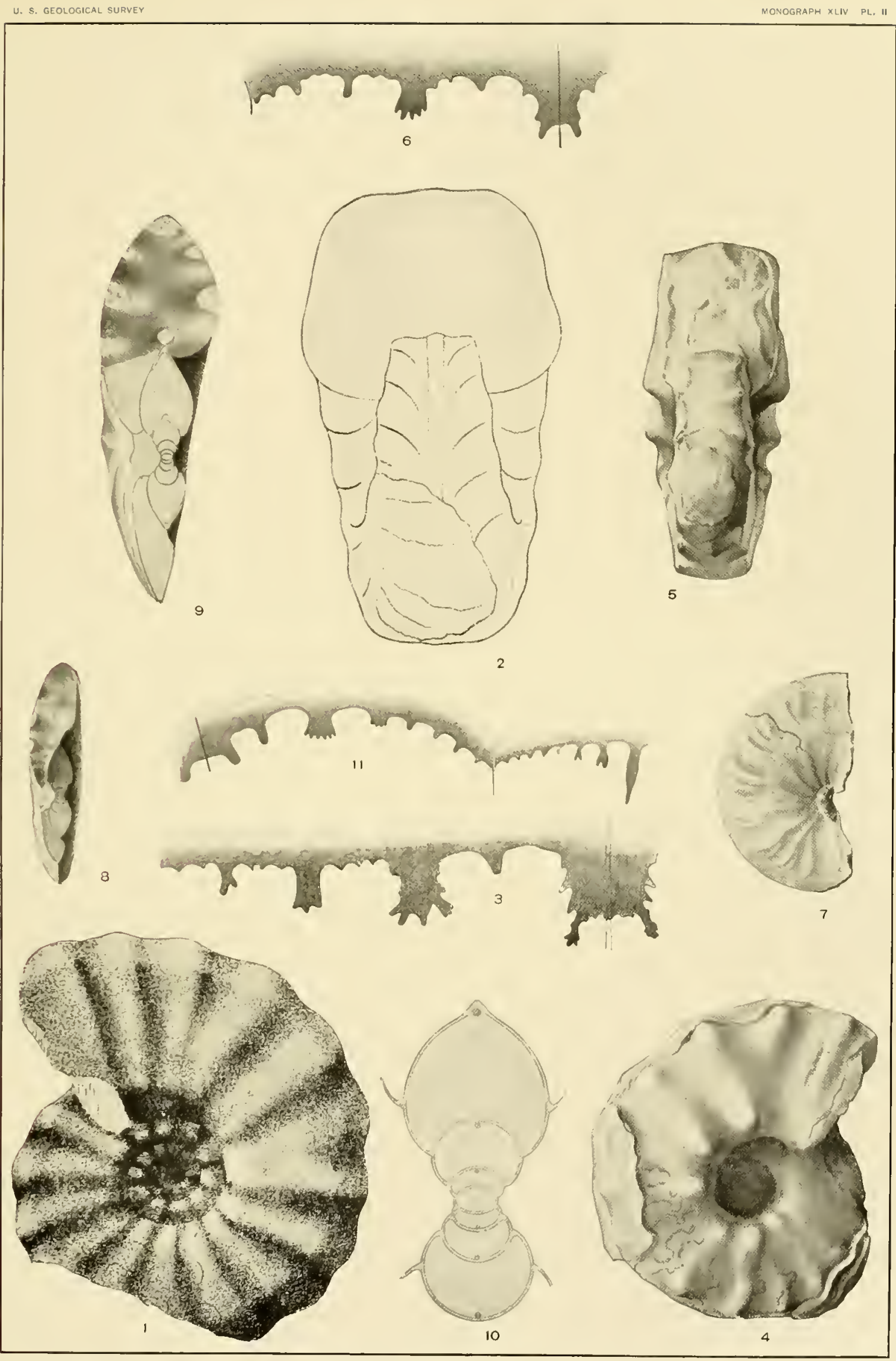

ROEMEROCERAS, PARATISSOTIA 



$$
\text { PLATE III. }
$$

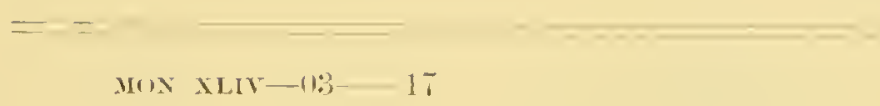




\section{I'L A T E I I I.}

\section{Paliatisotia, simenodinces.}

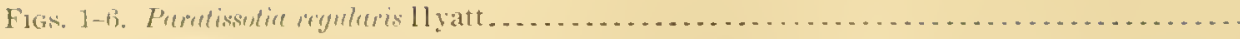

Figs 1-3. Natural size. The venter is restored in fig. 1, :me in fig. 3 the hollow keel is restored excert in lowest rolution of section, which is as seen ill fig 4.

4. Enlargeil view of sation of venter of liwer whorl of fig. 3. showing lonllow keel on its first al'pearance.

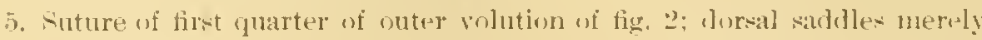
inclivated.

6. Murh alurarled sutures of last guarter of sine, to show the number and general fon wortions af the curves; the ventral hobe is more deeply worn than the lateral.

Cacluivaru, l'eru; L'per ('retaceous; my eollection.

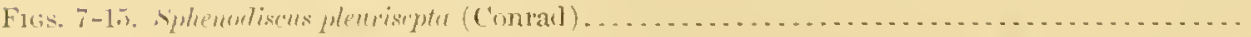

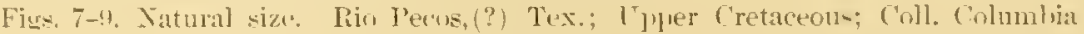
['niversity, New York, No. 108.'1.

10. Finlarged center of fig. !. The sutures in this were not so reariy seen at to make the olservation in this and fie. 12 entirely relialsle.

11. 1:2. Enlargerl vitlines of young of fig. :

1:3. (Hiler specinen than figs. $7-12$, showing the rounding of the venter.

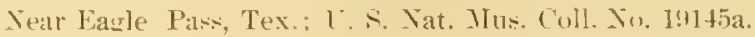

14. bex. sanse, coll, same, No, 19145l. Same age as figs, 7 ant $s$, lut slowing mure acute venter and nure proninent tubercles; this variation luas been glightly increasen by compressiom.

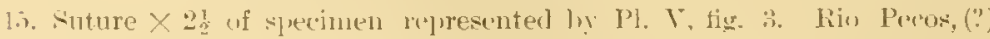
Tex.; Coll. Colmubia University, No. 10ssle.

All un this plate are casts.

230 


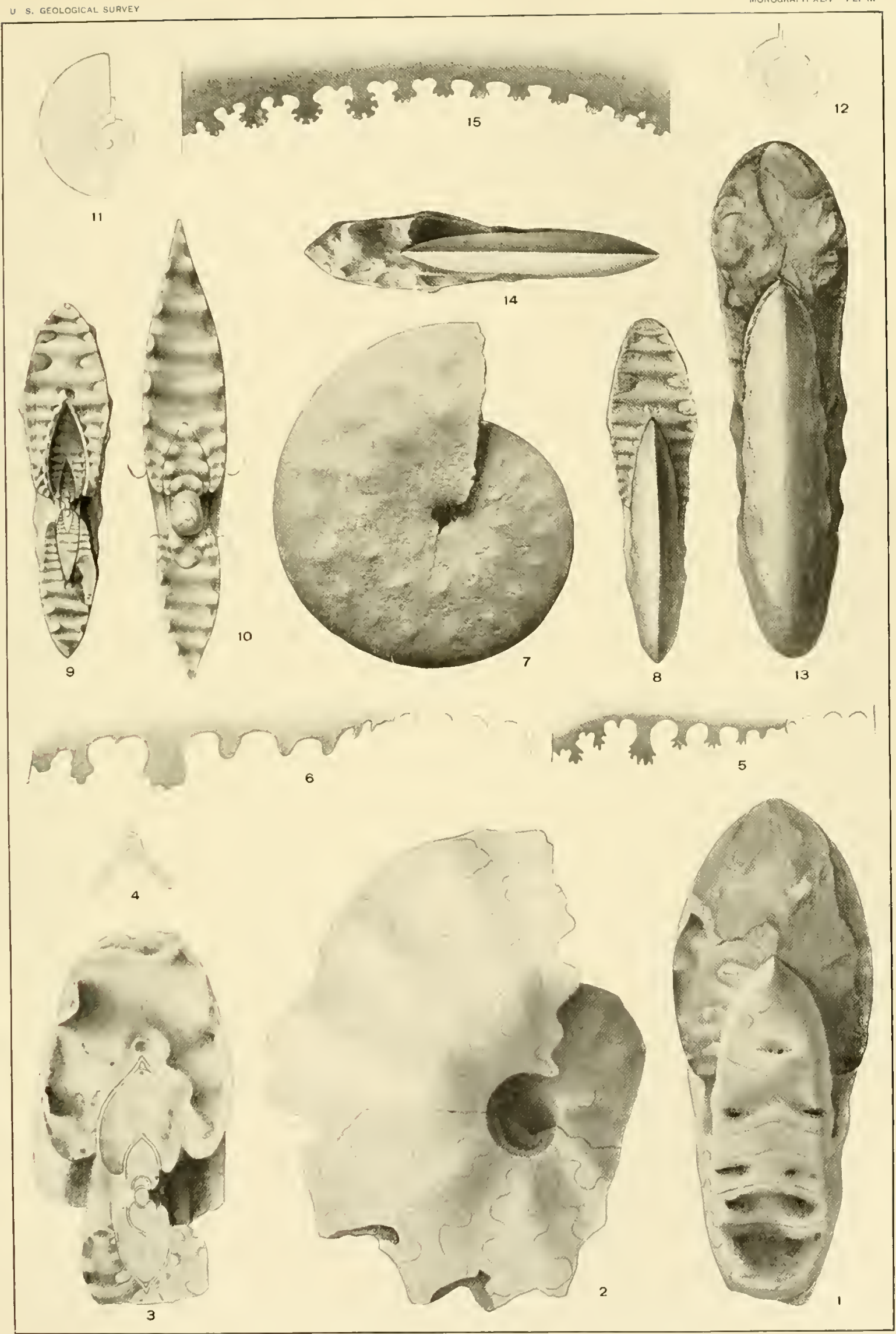

PARATISSOTIA SPHENODISCUS 



$$
\text { PLATE IV. }
$$




$$
\text { I'L A T F I I. }
$$

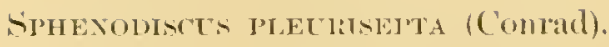
(Page 59.)

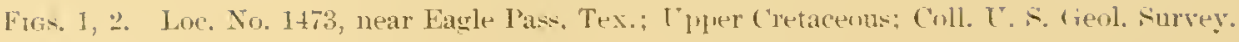
260 


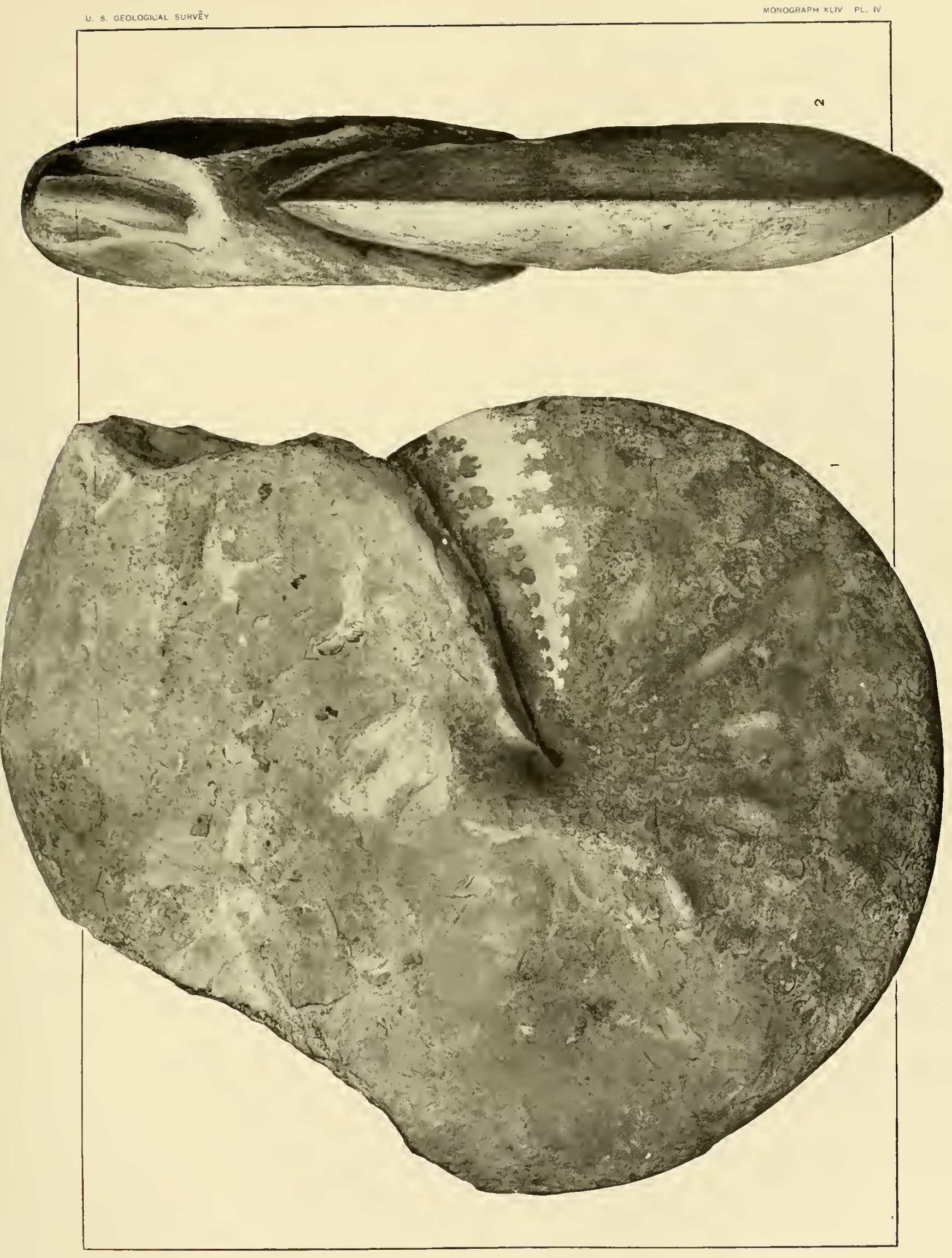

SPHENODISCUS. 

PLATE V. 
PLATE T.

SPHENOINATS.

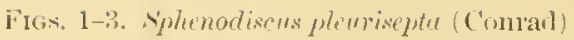

Figs, 1, 2. Fix. 2 is resturel in the lower part. The renter, where it is covered la the shell, is slightly more acute than is shown in the drawing. Fear

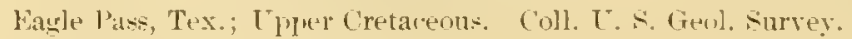

:S Tentral riew of same fosil as figured in Pl. I1], fig. 15. Coll. Columlia Lniversity, So. 10kilc.

Fre. 4. Sphonorlisens stmutomi Hyatt

Fig. 4 . The sutures do not show very well in this, and an enlargenl view of the first six saldles is given on Pl. V'I, tig. 5 . Same locality, age, and collection as fige. $1-2$. 

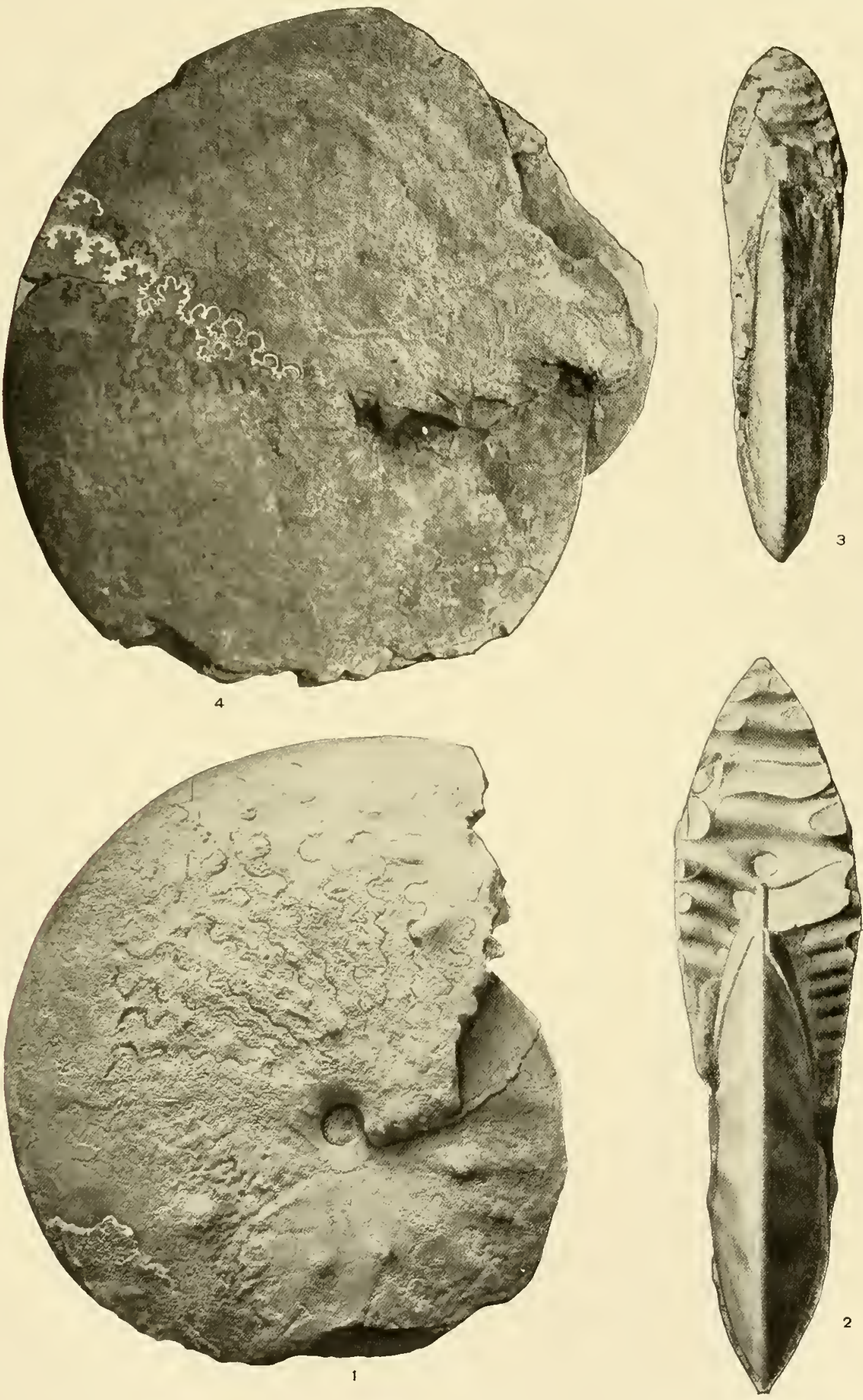

SPHENODISCUS. 

PLATE VI. 


\section{I'LA T F Y I.}

SPIFNODACE.

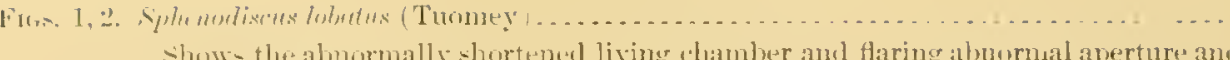

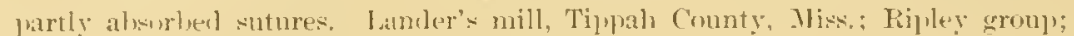

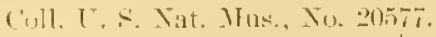

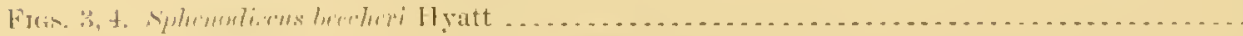

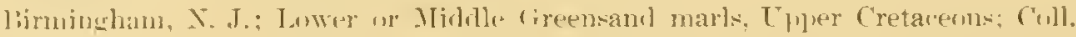

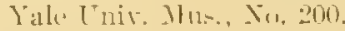

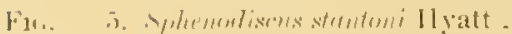

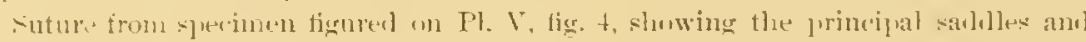
lnlex, : :

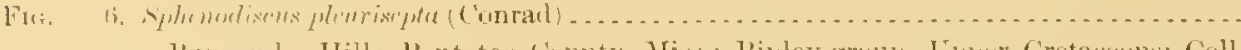

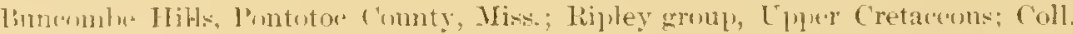
Frulcerick Braturn. 


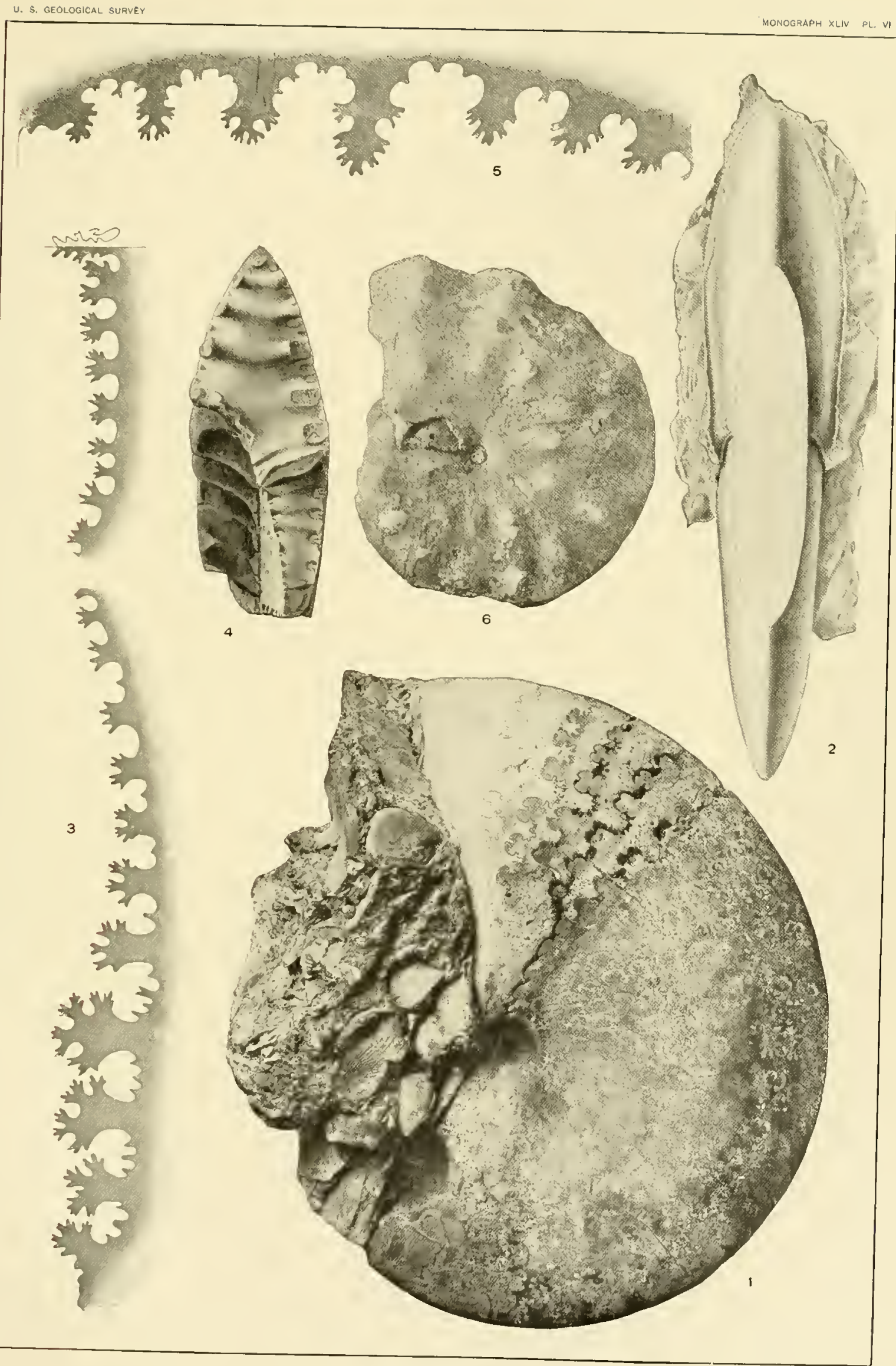

SPHENODISCUS. 

PLATE VTI. 
PI, A T V I I

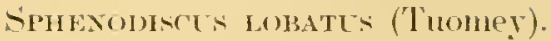

( I'agt 6ri.)

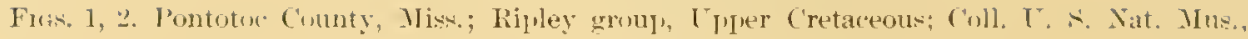
To. $2403, \frac{3}{4}$ natural size. 2 fiti 


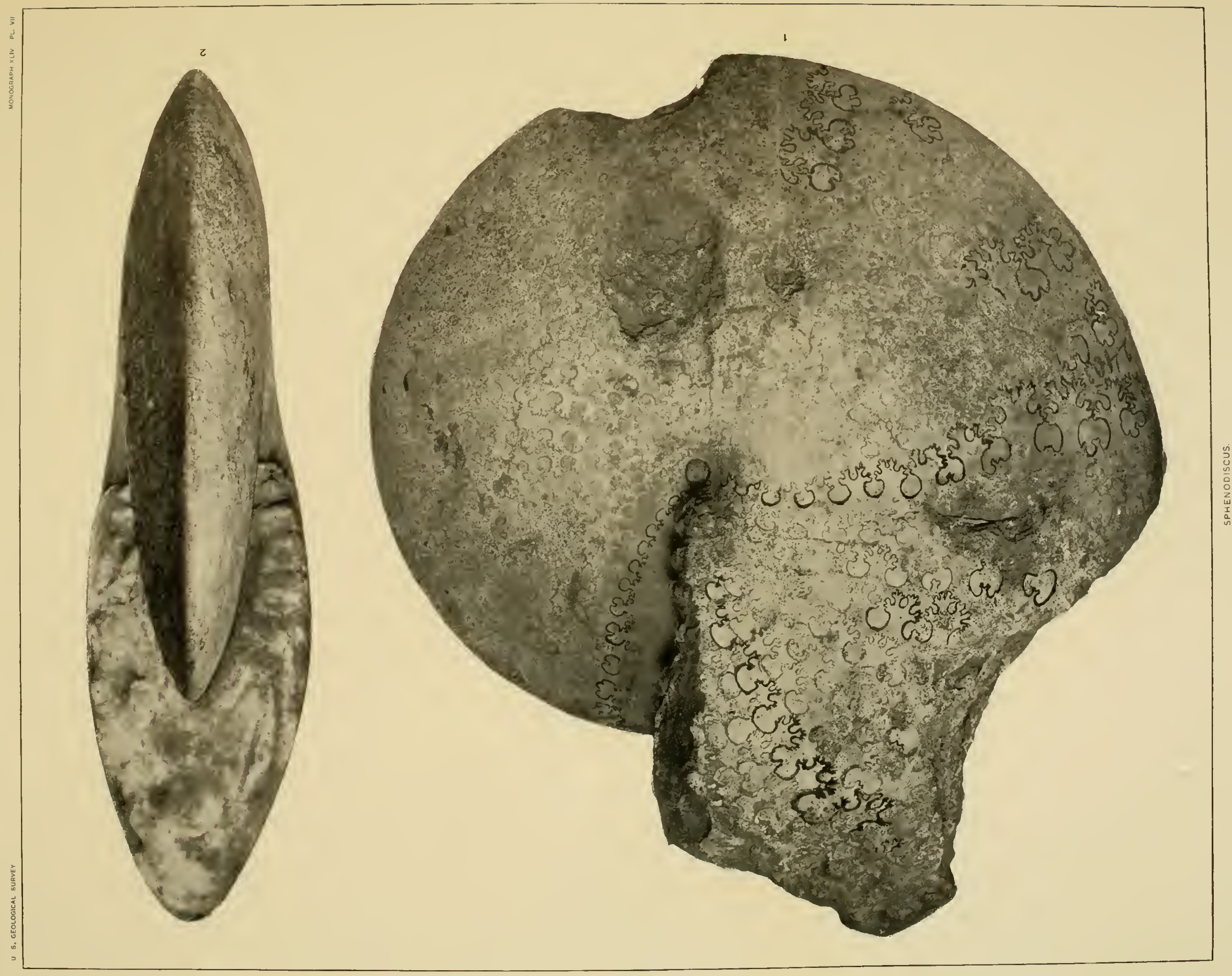





$$
\text { PLATE TIII. }
$$




\section{P L A T F I I I'I.}

\section{MIHExUISTLA.}

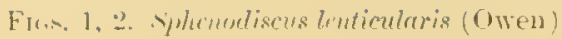

Fig. 1. Young of supposed tyjual form, natural size. Seer also Pl. IX.

2. Suture of same $\times$ his.

Yorean River,? Dakota; Fux Hills group: (oll. 1. S. Xat. Mus, No. Tont.

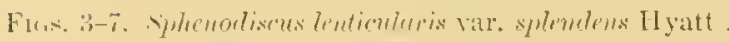

Figs. 3, 4. Views of fragments showing lateral ntures and internal, lonce younger rolution, natural size.

5. Ihrsal suture of unc sille of alsunt sane age as the one fat interl in on fig. 3, natural +ize.

1. Antisiphonal lohe of tig. 5, much enlared.

7. First thro sardles and siphonal sarllle to show ontlines on the next inner rolution tes that of fig. 3, natural -ize.

South Iakota: Fox Hilly group; ny collection. 


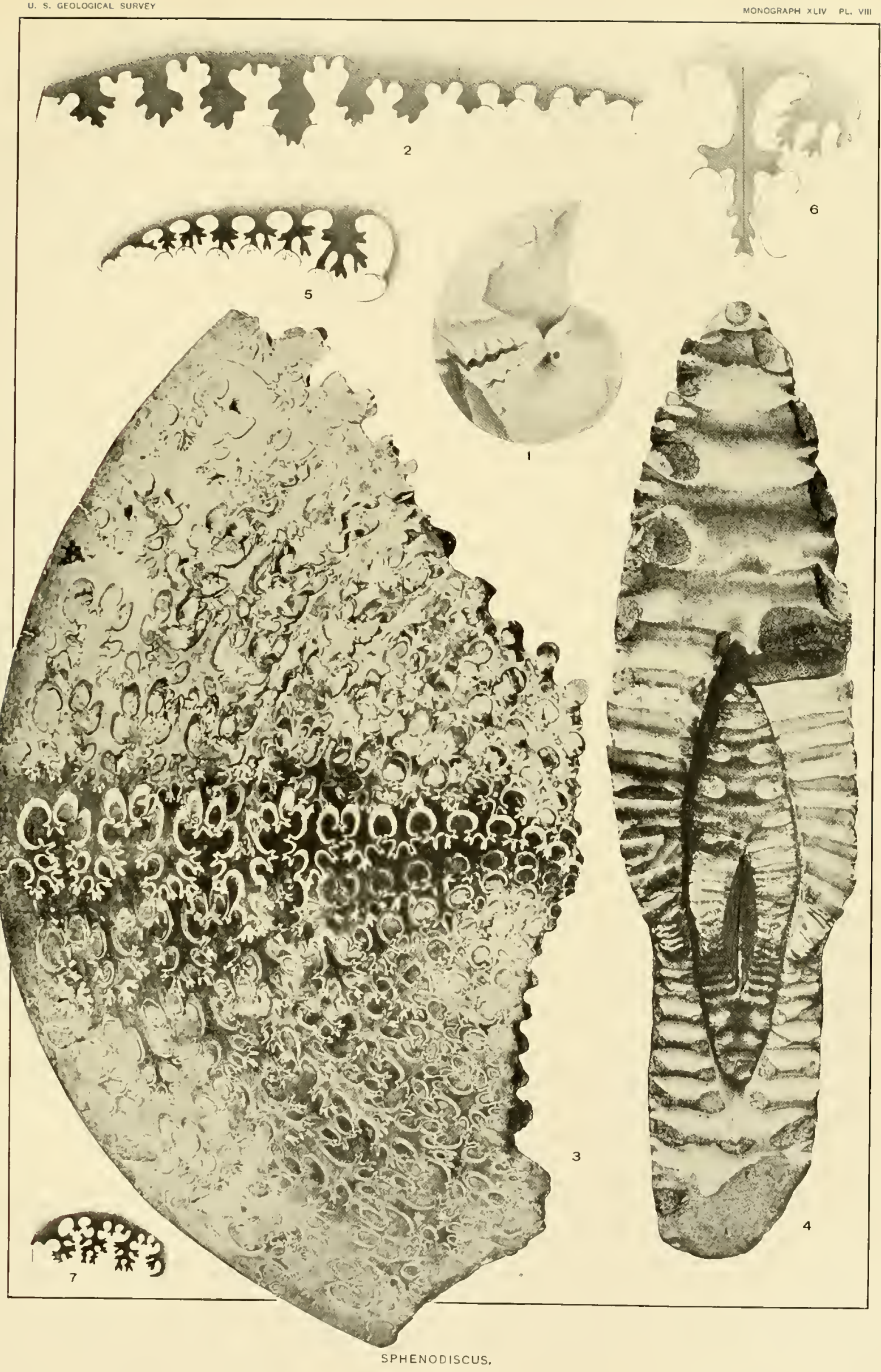



PLATE IX. 


\section{PLA TE IX.}

\section{SPHENOIISCES}

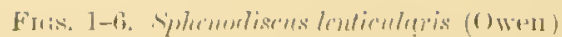

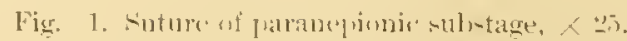

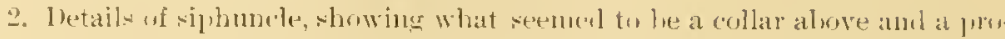
lomerl funuel reaching from the septum to the rovening of the collar.

3. Sutures of the neanie stage, showing the division of the thet prinitive latrral intro throw sadfles, first, second, and third of the later stages, and the monle of increase of the su-callerl anxiliary saldles and howe wn the line si involution, $\because \overline{5}$.

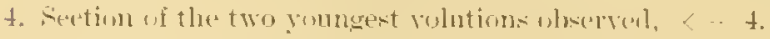

5. Latera! suture of later but not fully ahlult stager, t.

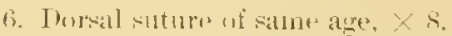

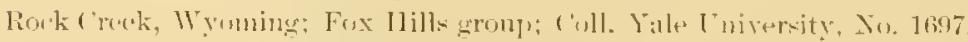

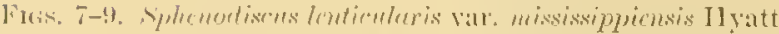

Fir. T. Latcral suture, natural size.

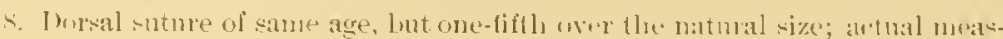
uremont is ts num. insteal of to mm., the length of the figure.

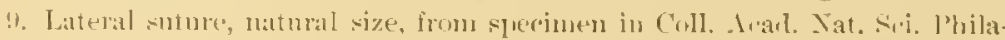
lelplial.

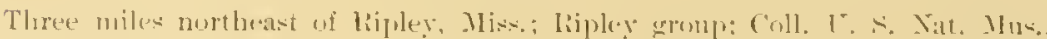

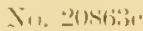

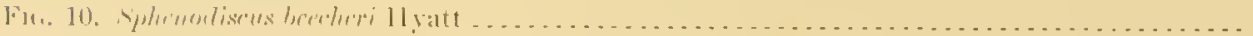

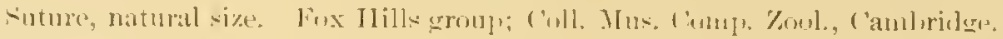

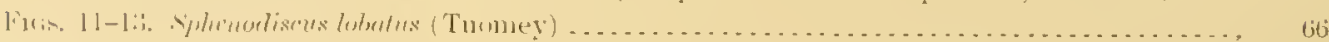

Fig. 11. Riglit sirle.

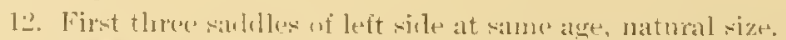

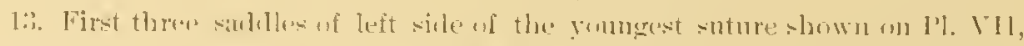
lig. 1, matnal size, for complarienn with tieg. 12.

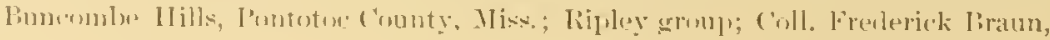
Biroklyn, X. Y. 
craminamezery

3 $\pi^{2}$
(2)

mon, if

4h herean a

$$
\text { तथल }
$$

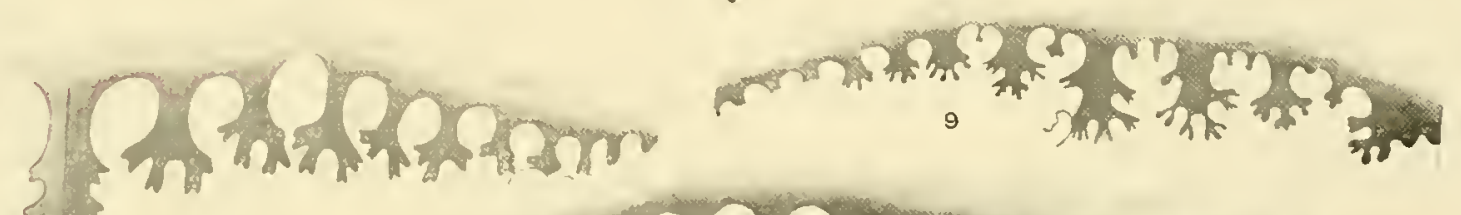
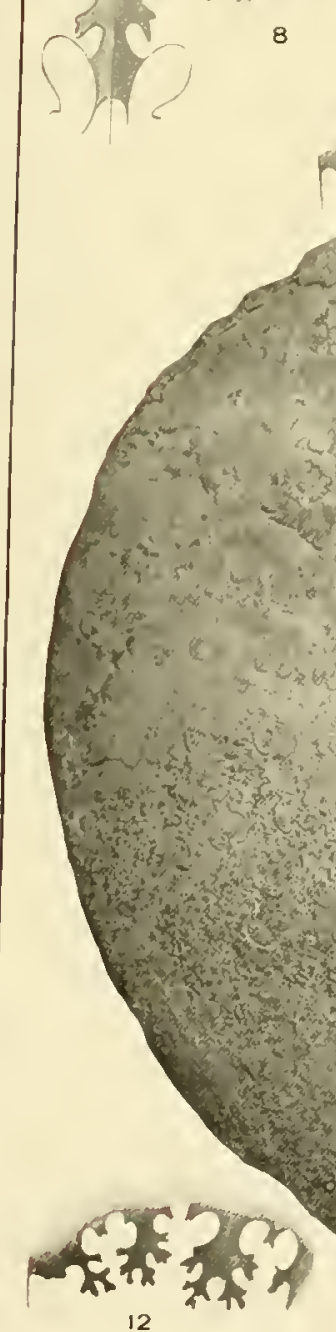

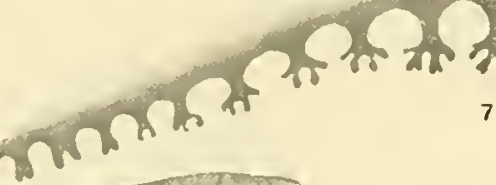

औरतथ
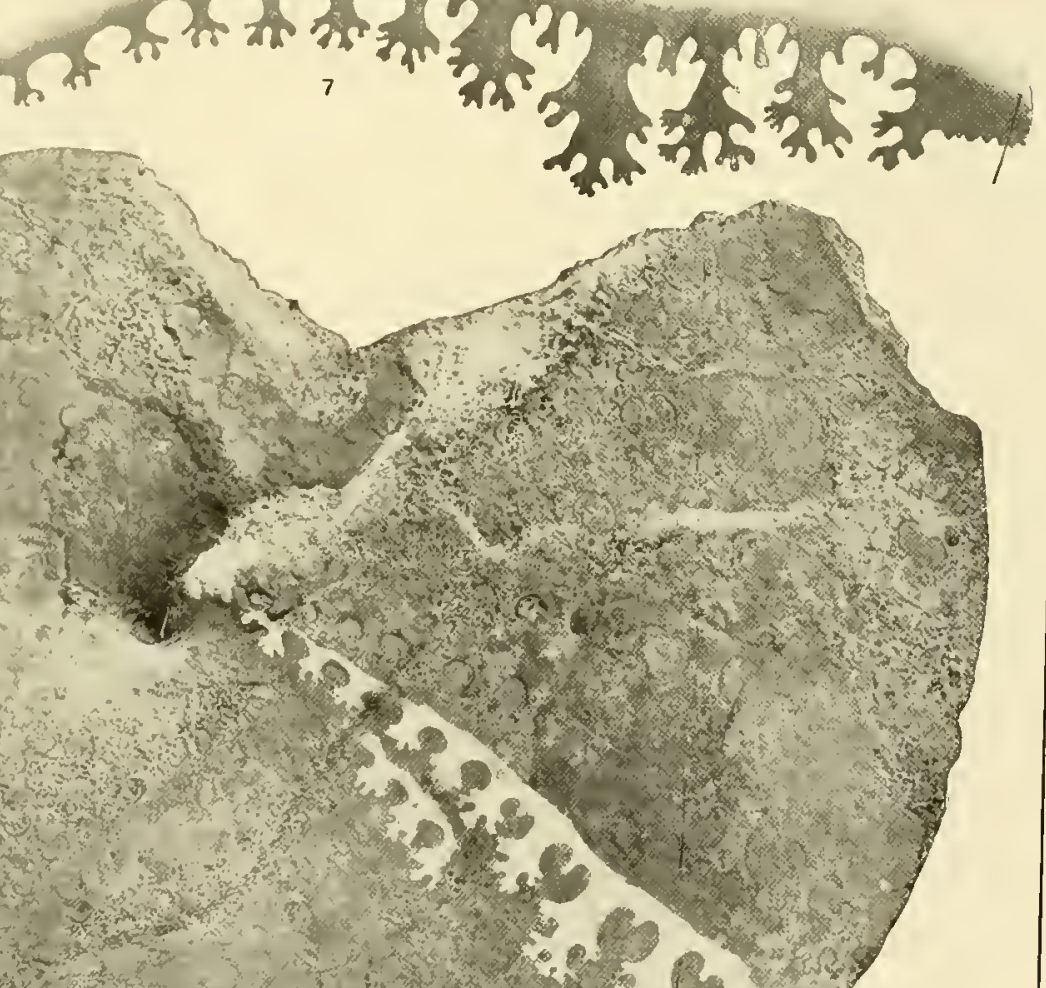

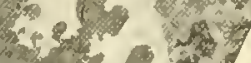

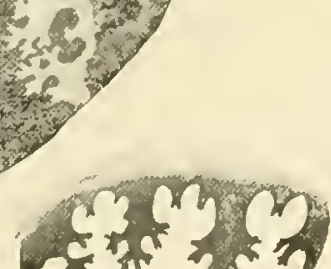





$$
\text { PLATE X. }
$$




\section{PLATE X.}

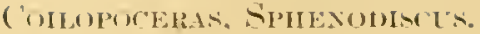

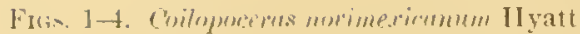

Figs. 1-B. Satural size, slowing hollow keel, etc.

4. One entire lateral suture and parts of two others. . 2. The toruinations if the saldles were more ol less pointed depreswions in the atst and were unt at first whervel.

Sear Cirtlage, V. Mex.; my enllevtim.

Fuis. 5-21. Coilupureus iolleti llyatt.

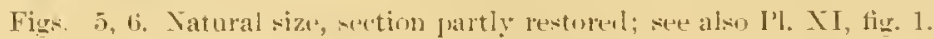

7. Latteral snture same as in sile view, 入 2 .

$\checkmark$ The dorsal =liture if same age, lmat as suture ar two later.

4. Joungest suture hown in tig. 5. x.2. - luwing tho matket rhauges that wenr on this volntion.

10. First to thiril suture of nepionie: stage, x :41).

11a. In entire suture of latter part of first wolution. $\times 20$

11. Two entire sutures of hrst yllarter of second rolution, $x 20$.

12. Entire suture of fourth fuarter of finrth volution. $x, s$, when the sutures are beginuiner tu show subdivision.

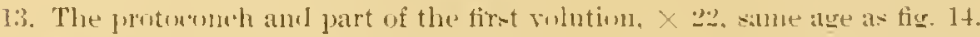

14. More enlarged side view uf the stme.

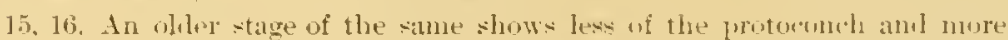
sutures.

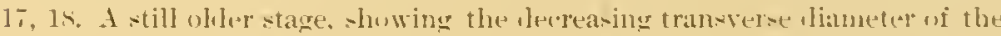
whlutian in the gontatitic stage, and the fir-t constriction on wark of a nepionic apertule.

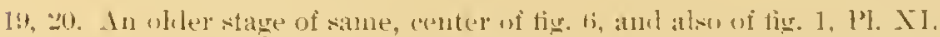

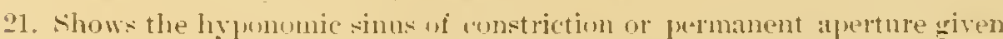
in figs. 18:411] 1!). The normal ratew growth and inclease in alianeter

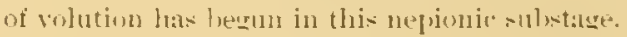

Siestr Carthage, X̃. Mex.; my anllevtion.

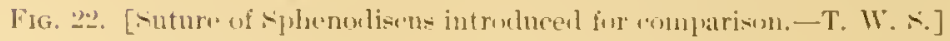




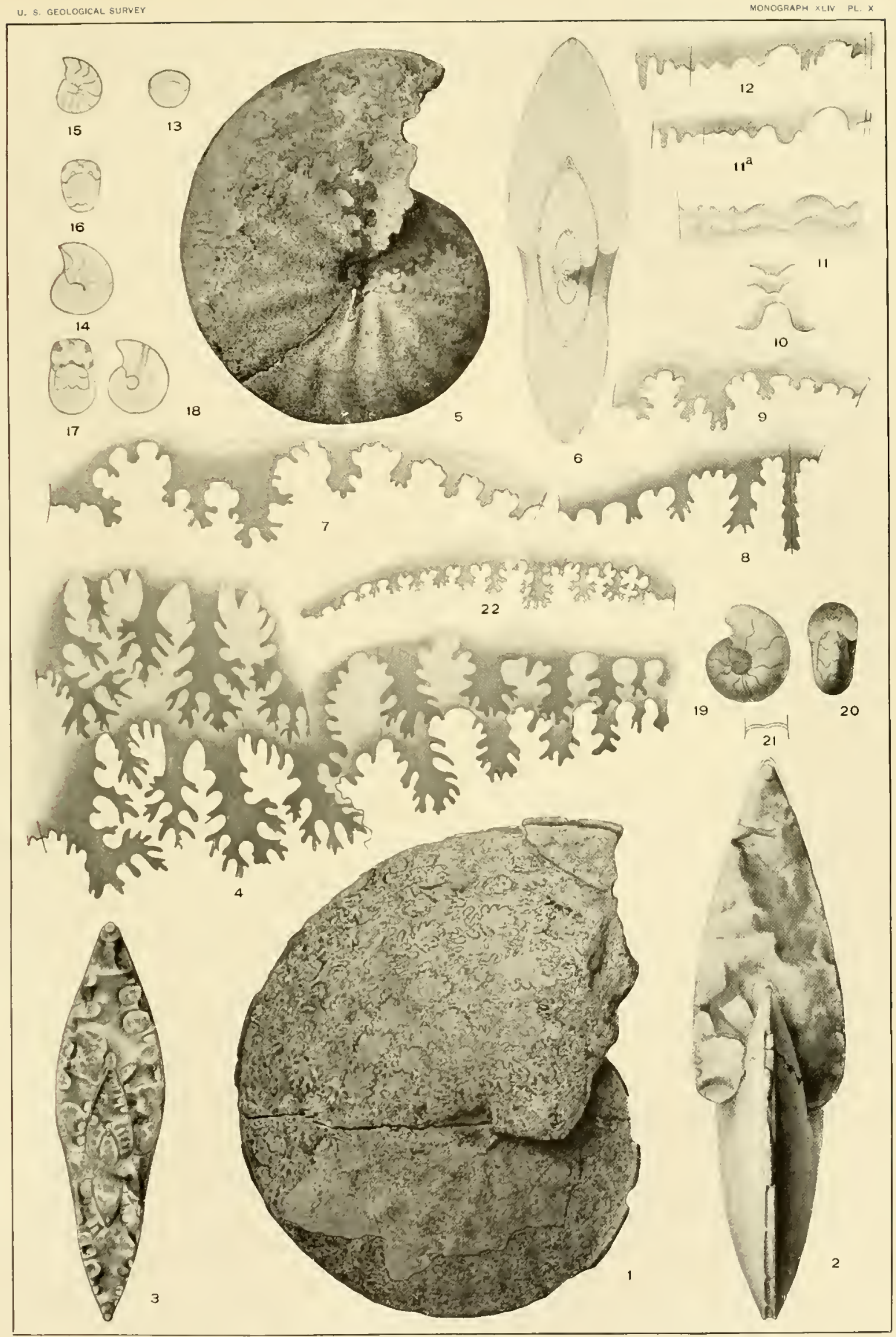

COILOPOCERAS, SHPENODISCUS. 



\section{PLATE XI.}




\section{PLATE XI.}

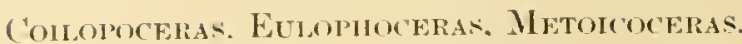

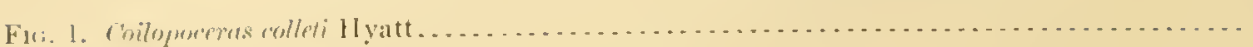

Section same at l'l. $x$, fig. hi, inlarged.

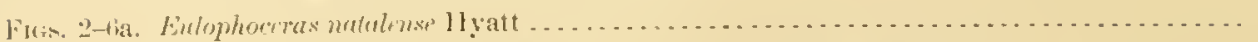

Fig. 2. Side taken before -1 tecinem was ground to show section.

3. Section somewhat more than natural size, and somewhat restoren, show: the umbilicus on the right completely filled by the shell layers. This filling orcurs in the adolesent stage, inclosing the lark spots on lroth silles of the center, which indicate that the shell alis not fill the umbilici at an earlier stage.

4. Hularged view of center restored.

5,6 . Shuws keel to have bean solit at this age.

ba. Enlarged drawing of hollow keel of venter connected hy a dotterl line.

Natal, Sonth Africa; Cretateons; Yale II

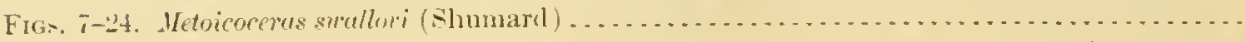

Fig. 7 . I'rotoconch ant part of nepionic volution, $\because 5+t$, artual transwerse diameter $3,10 \mathrm{~mm}$.

s. Sille view uf same, showing the abrupt benl in the protuconth hefore the nepionic tulke legan to be formed, and the first tro sutures.

9. Iptical section of same along dotted line in fig. s ans from front of view shown by the arrow.

10. Front view of the specimen before removal of the outer volutin, $x$ : sh.

11. Enlarged view of the ciecnm and first section of siphuncle, showing also the ventral lobe divicled hy a siphonal siddle.

12, 13. Xeanic stage, showing the aspicheeran-like form and tubercles, $\lambda t$.

14,15. A little older stage with living thamber complete at the umbilical shomleler, over 1 '2 rolution in length, $x t$. Back of this shows rounderl wister of the neanic stage just becoming dividel by the incoming of two rows of tubercles.

16, 17. Farly ephelic substage.

18. Sutures of fig. 12 alwut first quarter of fourth volution, $\wedge 12$.

19. Suture of serond yuarter of same volution.

2(1. Snture of prohalyly fourtl quarter of same volution.

21 . Dorsal suture of the second volution, $x$ 12.

2:- Inrsal suture of what was consilered to le the last of fifth or part of sisth volution, $x 12$.

23. Horral suture later in age than fig. 2:2, $\because .12$, of same age as snture Pl. X111, fig. 1.

24. Lateral sume of fig. 16 enlarged 3 cliameters. The ventral lohe has been distorted hy setting the siphonal satrlle at an eccentric angle.

Texas; (oloracto epuch; iny collection.

see Pl. Nill for other fignres of this species. 


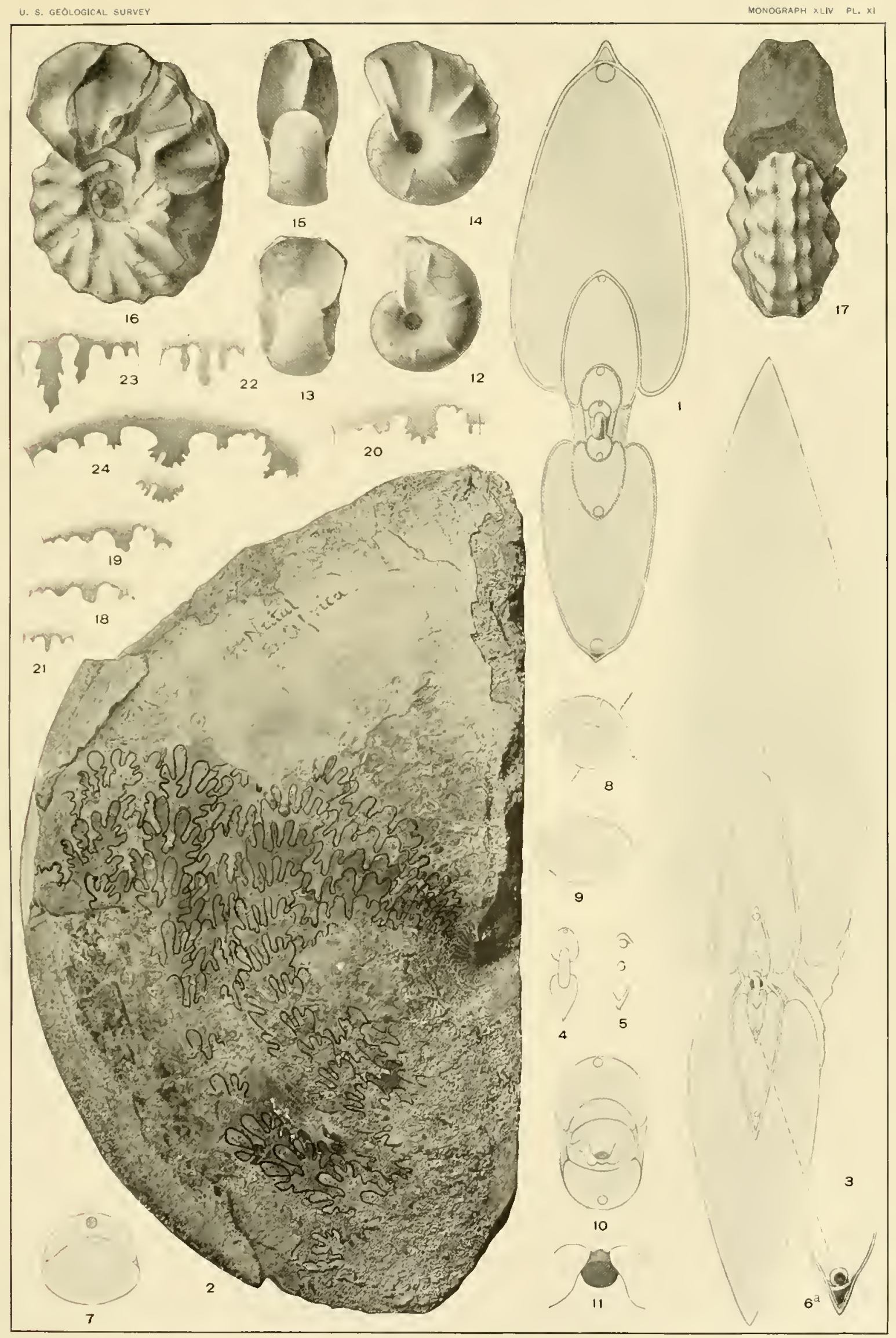

COILOPOCERAS, EULOPHOCERAS, METOICOCERAS. 

PLATE XII. 


\section{PLA TE XII.}

\section{Comopoceras, deneceias, SpHisNontscus.}

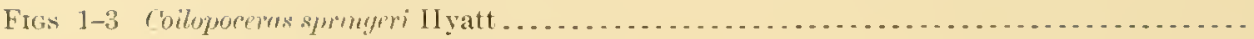

Fig. 1. Suture of right sille of whell.

2. Suture of leit sille.

3. Intiviphoual libe and first lorsal sarlde. Lower part of lobe below dotted line and right side is rewtored; the joint, however, was seen to he bifid. All natural size.

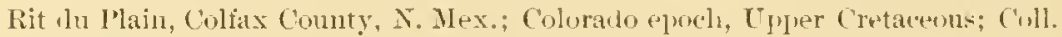
Mn. Comp. Zirol.

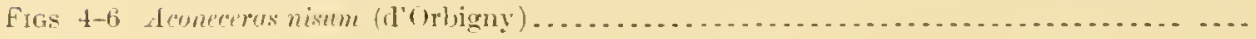

Figs, 4, 5. Natural size (after d'orbigny's figures).

6. Sutnres enlarged, showing similarity to plyvluceran outlines.

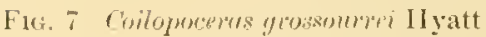

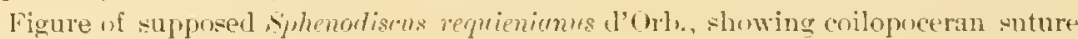
(After Grossunve.)

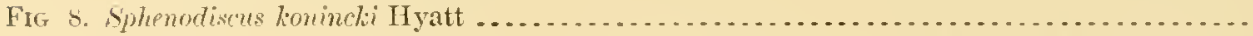

Fig. 8. Suture natural size. I'art of one suture is shown and this is continued hy the auxiliarieg of the next suture below.

Near Maestricht; Senonian; DeKoninck Coll. Mus. ('omp. Zool., Cambridge. 


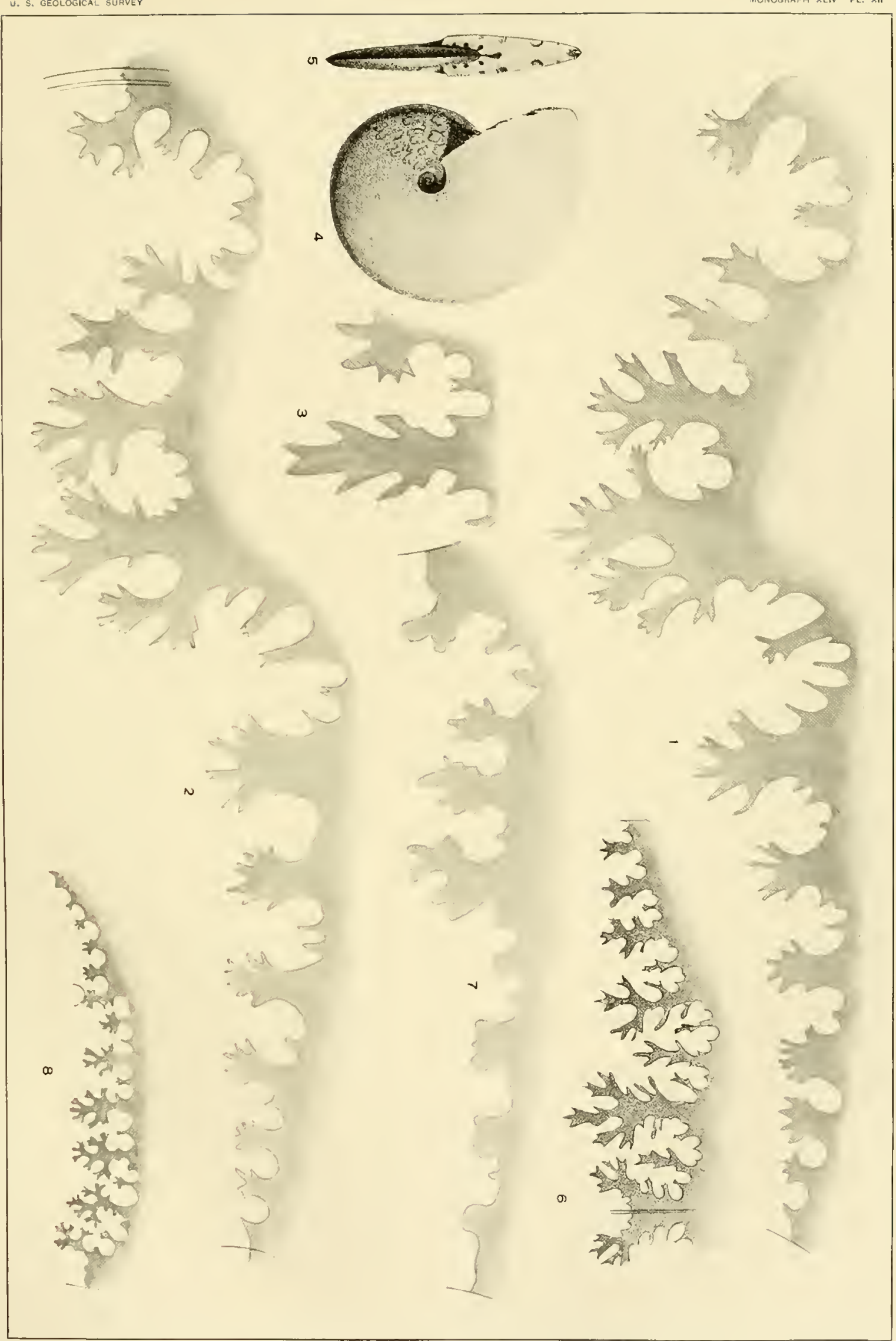

COILOPOCERAS, ACONECERAS, SPHENODISCUS. 



$$
\text { PLATE XII. }
$$




\section{P I A T F X III.}

\section{METUICOCERA-}

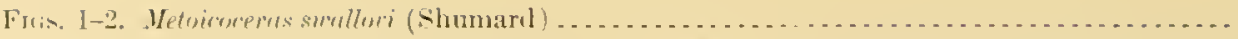

Fig. 1. Sanne as Pl. XII, figs. 20-2:3. Firt thres saddles and two bobes of lateral suture, $X 12$, to show mole of duvision of saldles and their distinct maroinals at this late neanic sulmiage.

2. (irason county, Tex; Coll. I). S. Martiu.

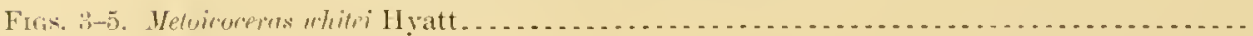

Fig. :3. Show shell on part of witer volntion and how litth this differs from thes tat-t.

4. Shmw this aho as well as the rounding of the living chamber on the venter

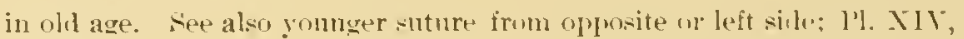
fir. 10 .

5. Last suture of another sperinen of about the sane sizas as fig. 4. Uper Kanab Valley, Ltah; Coll. I'. S. Nat. Mus. 


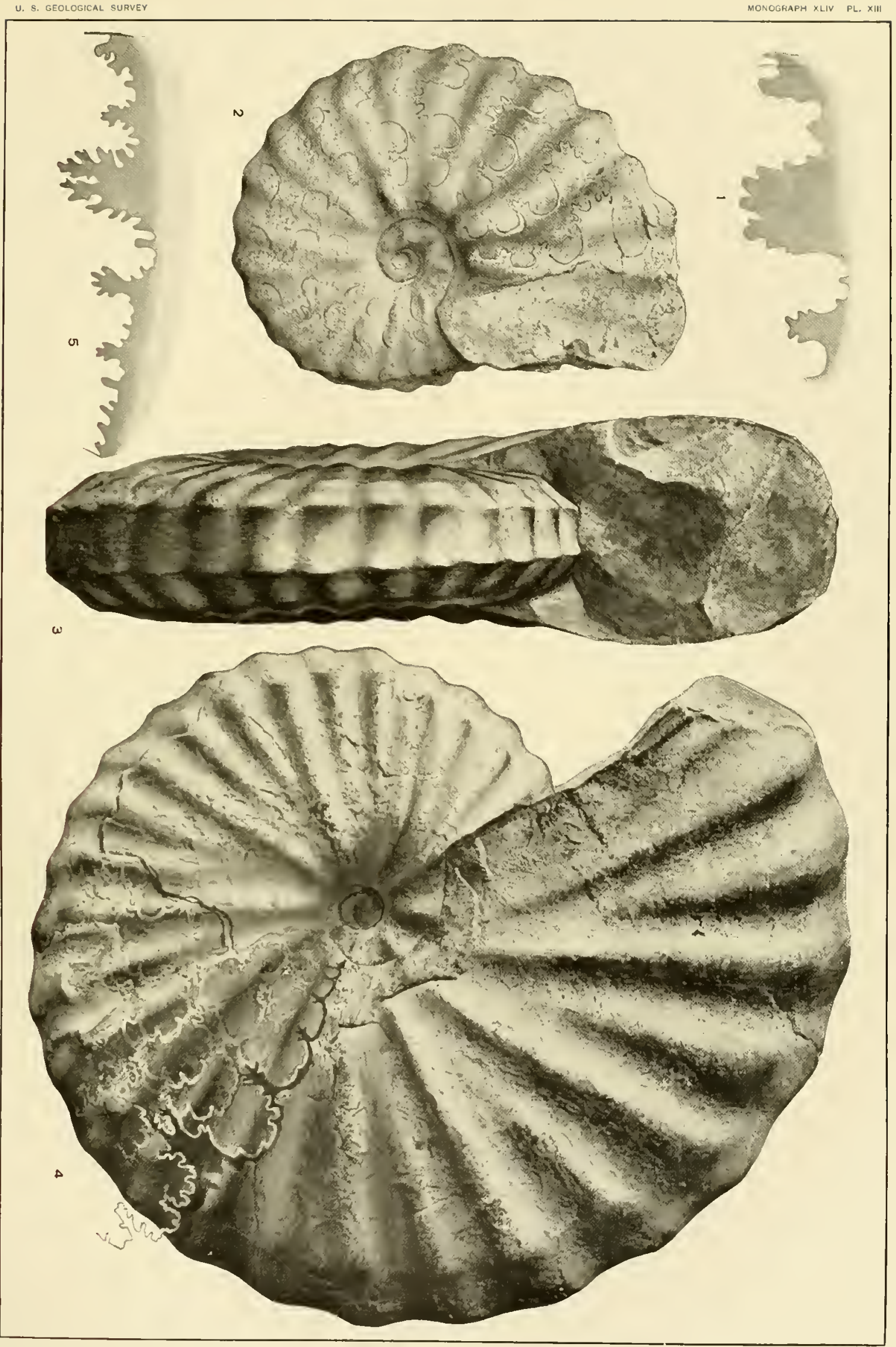

METOICOCERAS 

PLATE XIV. 


\section{PLATE XIV.}

\section{Metoicoceras, Vascocerax.}

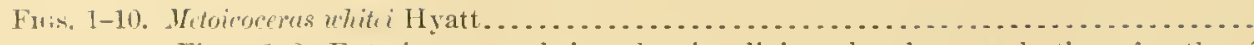

Figs. 1,2. Exterior, natural size, showing living chamber nearly three-fourths of a volution in length, complete to its inner borler.

3 . Lateral suture of the last septum, $<3$.

Elun Fork, Horton's mill, Dallas County, Tex.; Colorarlo epoch.

t,5. Sreeimen somewliat older than fig. 1, natural size.

Probably from Texas; my collection.

6. Lateral sutnre, $\times 3$. Living chamber, probably nearly complete, is one-half of a volution in length.

$7, \leftrightarrow$. Type of pleries, natural size.

9. Suture, natural size, wmewhat older than fig. $t$, whole aliameter about 56 nim.

Elm Fork, IIorton's mill, Dallas County, Tex.

10. Lateral suture, left side of fig. $t$, Pl. XIII, taken irom halfway between the base of the living chamber and the orening of the same.

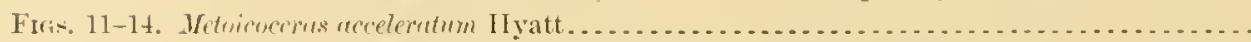

Figs: 11-13. Fpecimen in which the living chamber is complete and over threefourtlis of a rolution in length, natural size.

14. Part of suture visible at base of living chamber on the opposite side to that figured, $\times 4$.

Elin Fork, Iorton's mill, Inallay County, Tex.

F11. 15. Ifotocereres whiti II yatt.

Dorsal suture, natural size.

Elm Fork, Horton's mill, Irallas County, Tex.

Fur, 16. Tinscocerde hatli ( $\mathrm{H}_{\text {yatt }}$ )

snture, natural size.

280 


$$
\text { or } 18 \text { os then }
$$

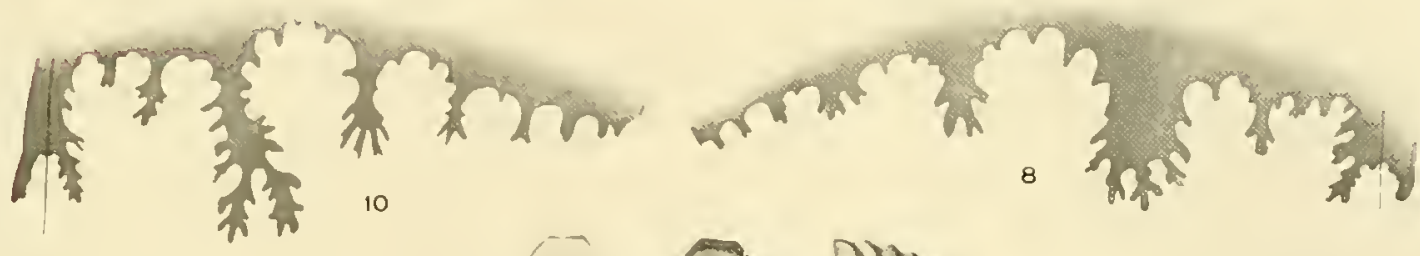

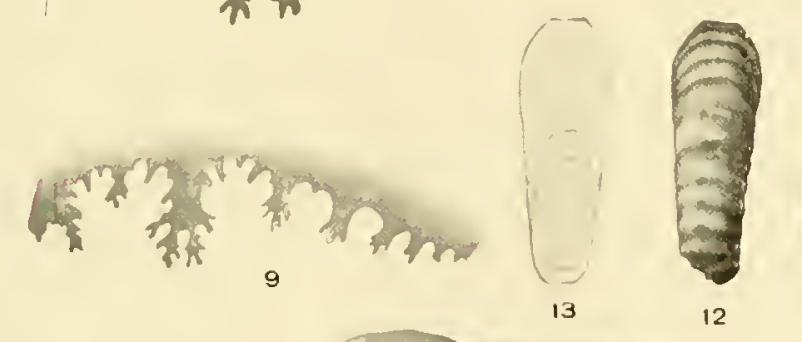

in $r_{14}$
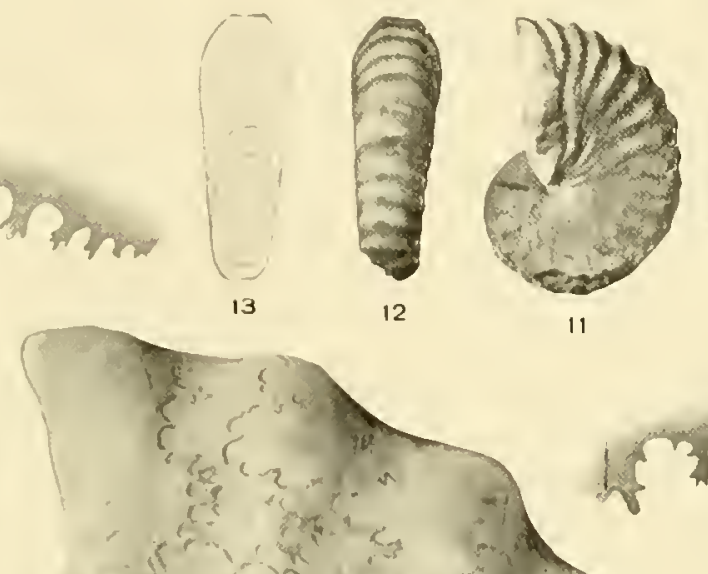

ry

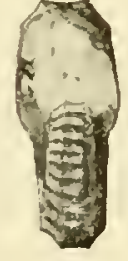

2

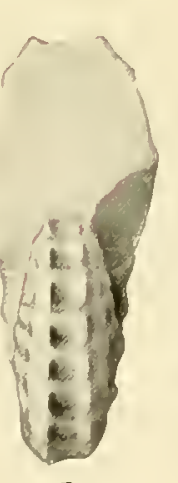

5
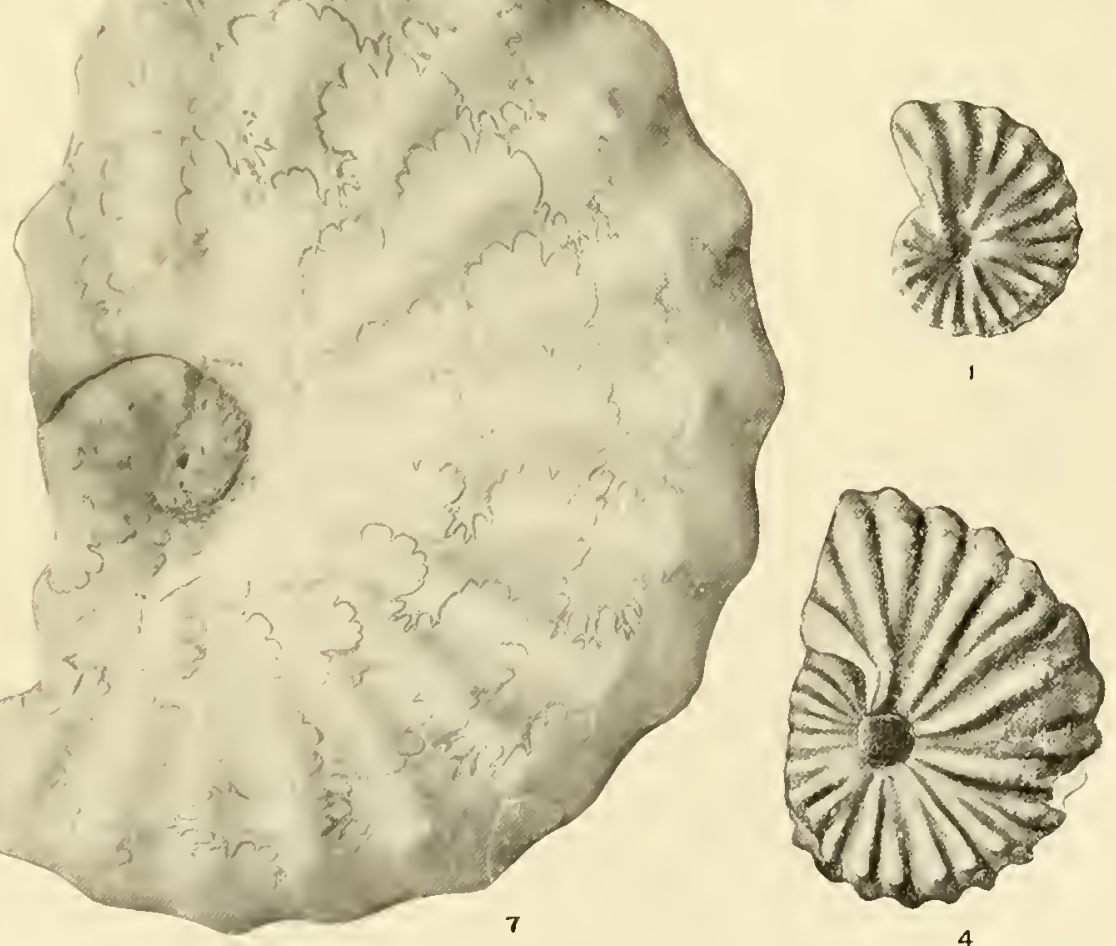

METOICOCERAS, VASCOCERAS, 



\section{PLATE XV.}




\section{PLA T E X Y .}

\section{Metolcoceras. HeINZia.}

Page.

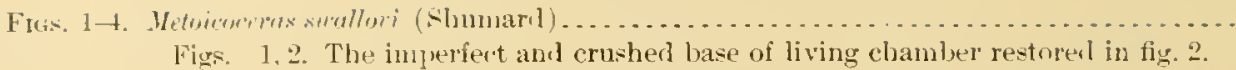

3,4 . Right and left sutures of fig. 1, of same age, showing differences in number and outlines of anxiliaries. All natural size.

Texas; Columalo ejorh; Coll. Amer. Mus. Nat. Ilist., New York.

Firs. 5-8. Metsicorepas yiblusum IJ yatt.

Figs. 5, 6. Natural size.

7,8 . Suture of right and left sinles, respertively, as seen when looking st the - perimen tig. 5 , natural size.

Texas; ('oll. Amer. Mus. Nat. Hist., New Yurk.

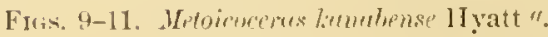

Figs. 9. 10. Natural size.

11. Snture of left sicle of the second quarter of nuter volution, $\times 21$. The living chauber extented from the rrack in the sprecinen, fig. 10 , for the remaining me-half volution, and wa most probahly nearly tomplete.

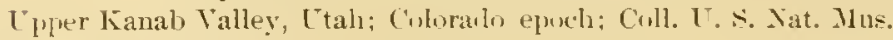

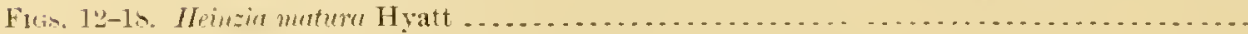

Fig. 12. Entire specimen, right side.

13. Same selarated anul renter excavated, left side.

14. Front view of same, renter one-hali restored.

15. Ventral vitew of fig. 12.

16. Suture at plate marked by arrow in fig. $13, \dot{x} 7$, actual length 3 mm.

17. Dorsal suture, $X 8$, of second quarter of onter rolution of fig. 12 , one-lualf actual diameter $2 \mathrm{~mm}$.

18. Sufure of right side fourth quarter of onter volution of fig. $12, \times 3$.

All natmal size except figs. 16,17 , and 18.

Escragnolles. France: Barrémian; Coll. Mus. Comp. Zool., Cambridge.

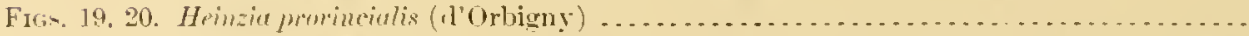

Fig. 19. Dorsal suture next to unter volution across the mbilieus and opposite termination of outer volution, $\times 9$, nne-half actual diameter $1.5 \mathrm{~mm}$. of same type, lut more immature at the same age than in Meinzin mutum.

21). Natural size.

Loeality and collection same.

" To dex ription of this species was found in the manuscript.-T. W.S. 


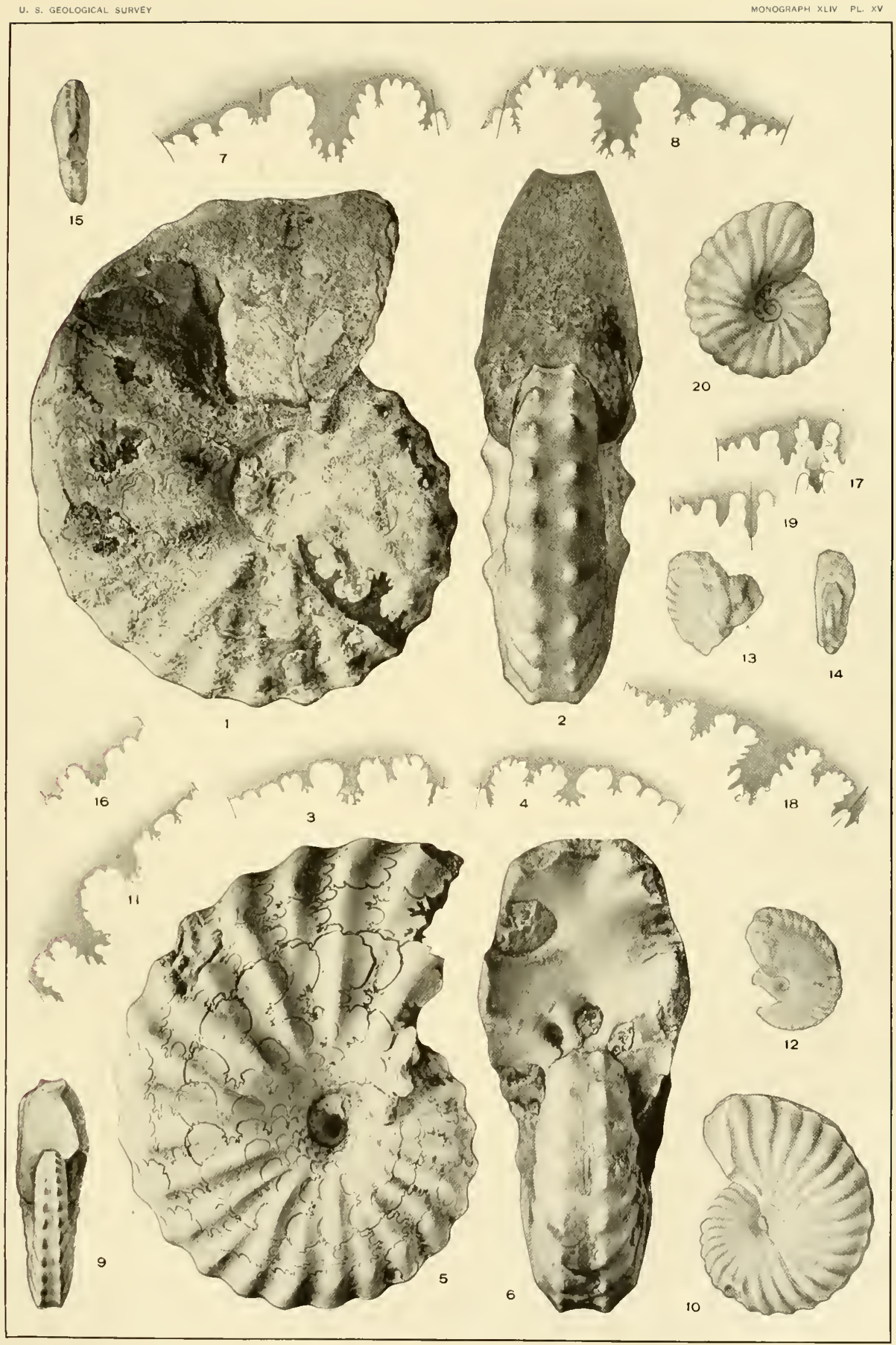

METOICOCERAS, HEINZIA. 

PLATE XVI. 


\section{PLATE X I T.}

\section{HeTYZIA. KNeMHCERAs.}

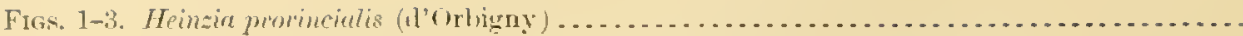

Figs. 1, 2. Same as Pl. XV, fig. 20, bruken to show young, $\times 3$.

B. Lateral sutur of the semond quarter of outer volution of $\mathrm{Pl}$. $\mathrm{XV}$, fig. $20, \times 4$.

Escragnolles, France; Darrimizn; Coll. Mns. Comp. Zuol., Cambridge.

Figs. t-s. Kinemireress syriacem (won Buch)

Fig. t. Nitural size, showing length of living chamber, over one-fourth of a volution. Coll. Mus. Conp. Zool., Cambridge.

5. Lateral suture, $\times 2 \frac{1}{2}$.

6. Uneompresied typical fosil. Coll. Tale 11 us.

7. Part of suture of right sile, $\times 2 \frac{1}{2}$, to contrast with next figure.

8. Suture uf left side, $\times 3$. Outlines perfectly vreservesl.

Mount Lebanon, Syria; Cenomanian.

FIGs. 9-10. Knemiceras compressum Hyatt. Natural size

Locality, same as last; Coll. IIus. Comp. Znol., Cambridge.

FIGs. 11-1t. Knemicerus compressem. var. subcompressum Hyatt

Fig. 11. Specimen in collection of Columbia Inniversity.

12. Section showing transition from a rounded young to the flat and then coneave venters of the succeeding stages, $\times 2$, from specimen in Xus. Comp. Znol., Caml ridge.

13a. Enlarged view of eenter.

13b. Enlarged view of protoconch and first whlution with first and seend sutures.

14. One of Conral's specimens, natural size. Suture abraded. Coll. Tale Inus.

Locality, same as last.

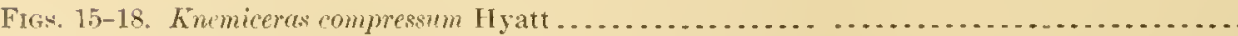

Figs. 15, 16. Type of sjeeies. Sutures abradert.

17. Suture from line of involution to first lateral lobe at breadth of $5 t \mathrm{~mm}$, on left side.

18. Suture on right side to thiril lateral saddle at breadth of $63 \mathrm{~mm}$.

Locality, same as last.

Fif. 19. Knemicerus compresum var. subempressmm flyatt. ........................

Yentral riew, natural size, of specimen in eolleetion of Columbia University. For sutures see fig. 11.

Locality, same as last. 


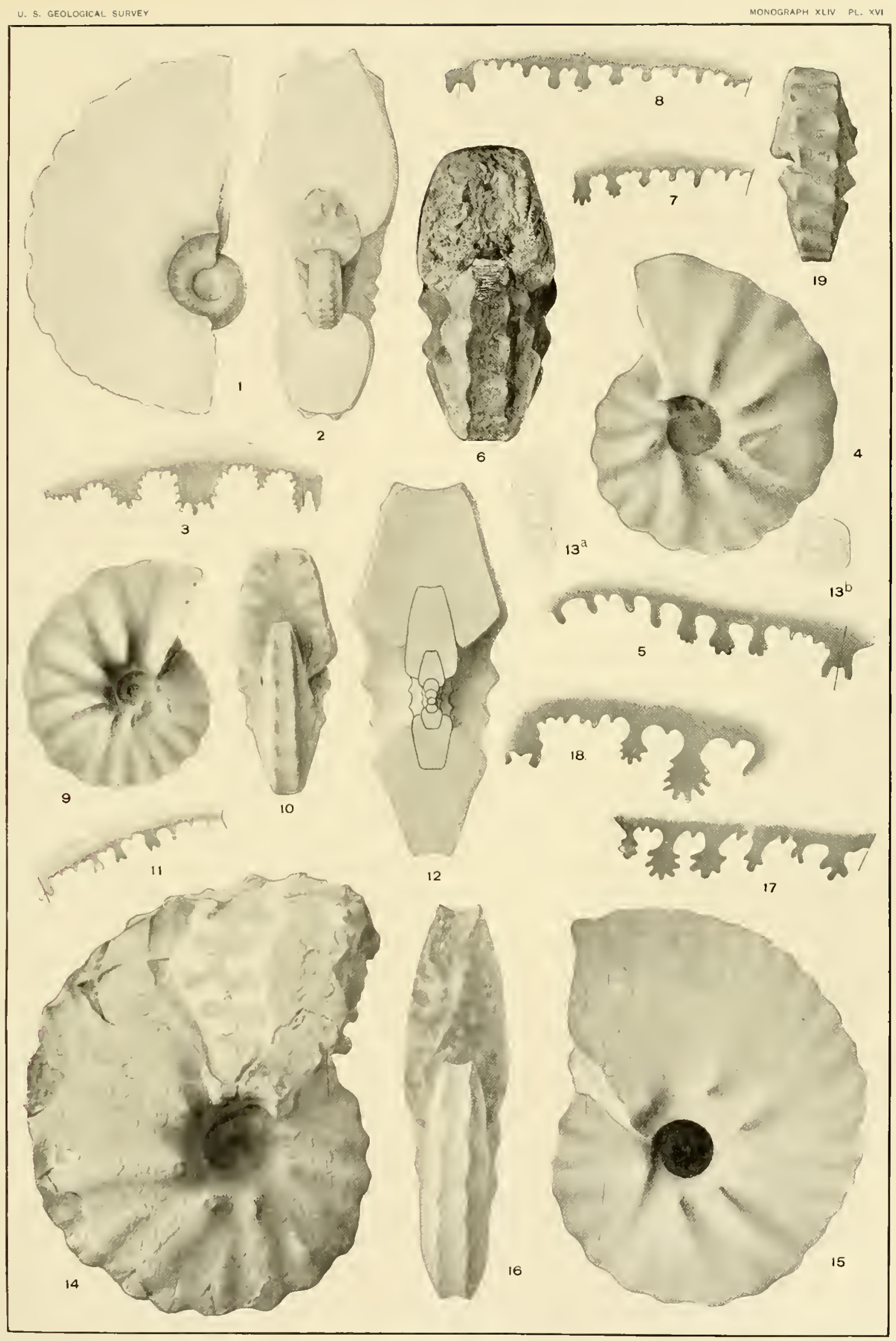

HEINZIA, KNEMICERAS 



\section{PLATE XVII.}




\section{PLATE XVII.}

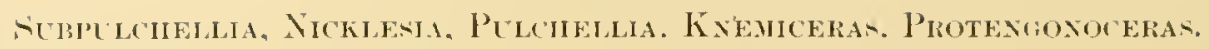

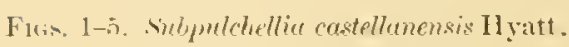

Foger

Figs. 1, 2. With shell complete un sirle of fig. 1.

3, 4. Same fusil, shell partly taken off. liight sille of fig. 3 show length of living chamber abuut one-half of last volution.

5. Litteral suture of fig. $3, \times \therefore$.

All natural size exeept fig. 5 .

Cactellanes, lirance; Teoromian; Coll. Mus. C'm11\%. Zool., Cambridge.

Fiss. ti-s. Nicklesin dumusiann (d'orligny) ...

Figr: 6,7 . Tatural size.

x. Lateral suture, $<: 3$.

Locality and collection same as last.

Figis. 4-1:2. Puldellie rompressissime (1'Orhigny)

Figrs. 9-11. Natural size.

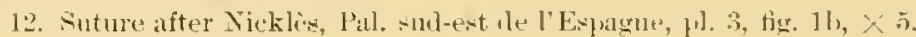

Locality and (oullection the same.

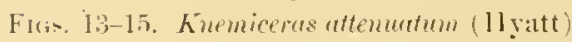

Figs. 13, 14. Natural size; shows living whamber nearly three-fourths of a volution.

1.5. Suture, $\times 2$.

Celendin, Peru; Cenumanian?

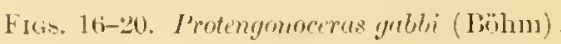

Fig. 16. Shows living chamler to have one-half a volution in length. Shell is preserved on the living channher.

17. vection shows the concave venter with lateral rislges at an early stage.

18. Ventral view of same.

19. Sejtum of sante, $\times 2$.

All natural size exrept the last, anol all in coll. Mhs. Comp. Zool., Cambridge.

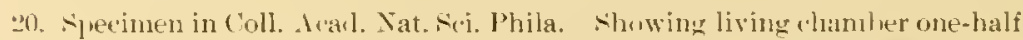
of a volution, jart of aluertue on right side, and old-agre fulds.

Arivechi, Somora, Mexieo. 

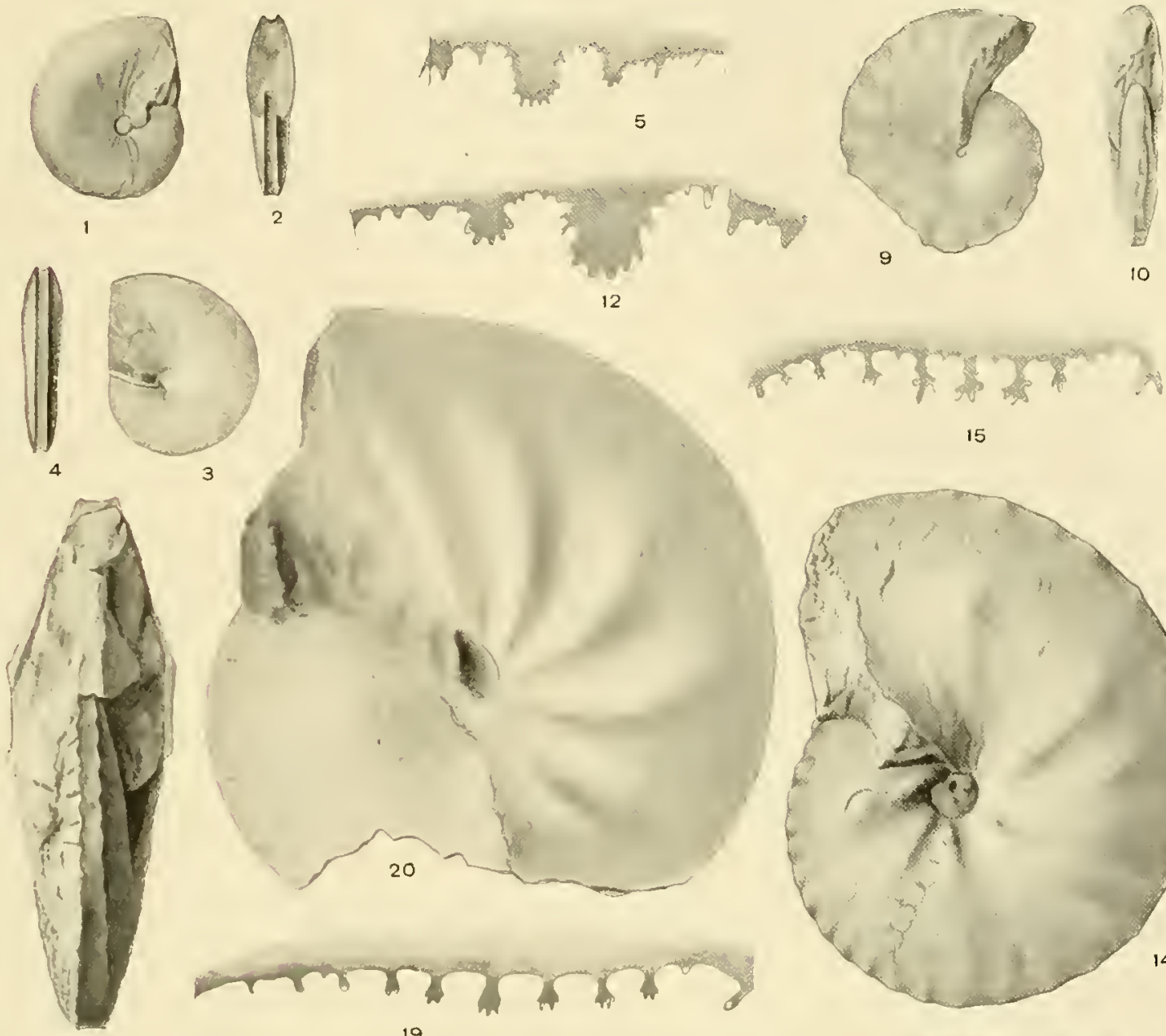

\section{5}
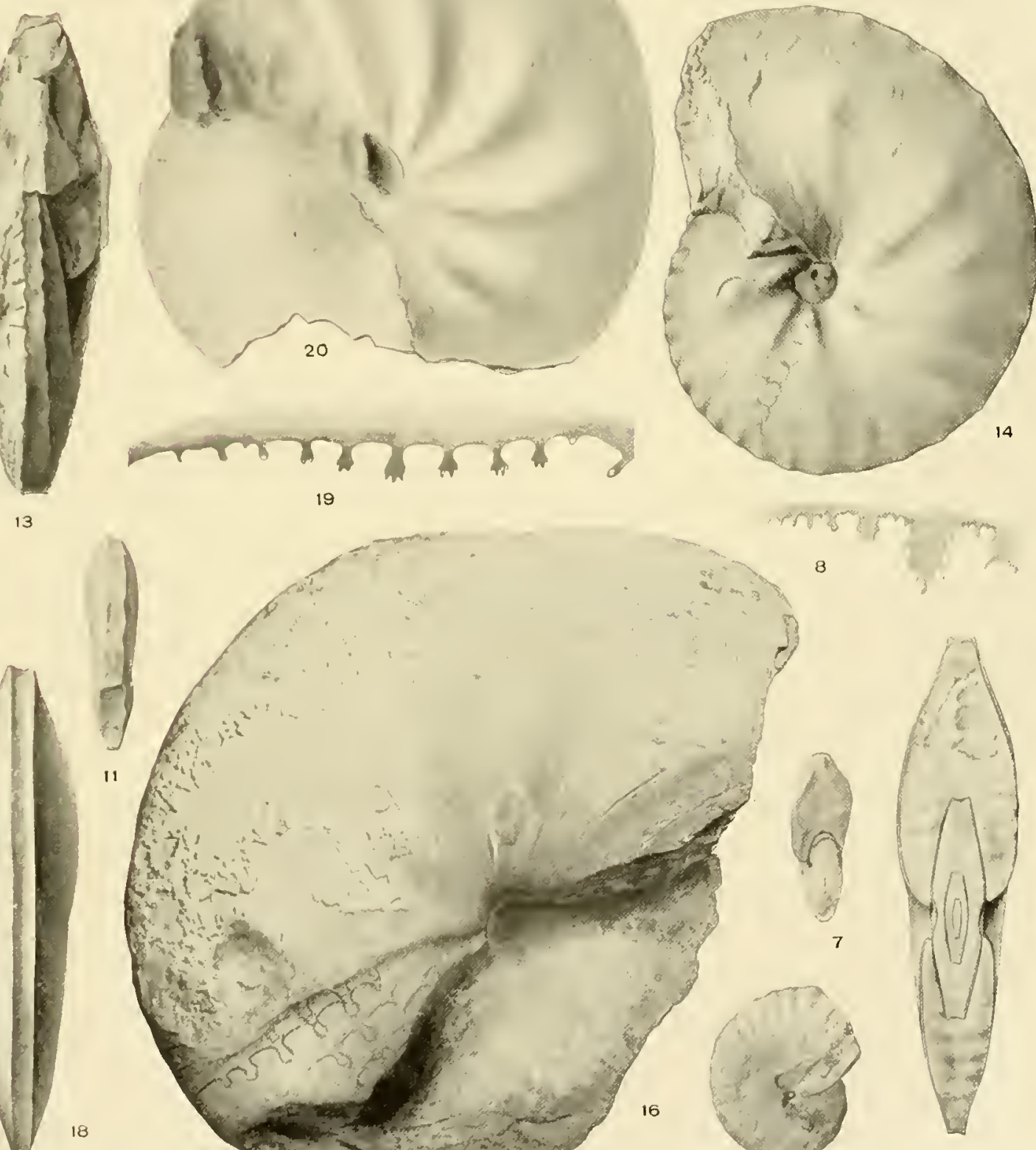

19

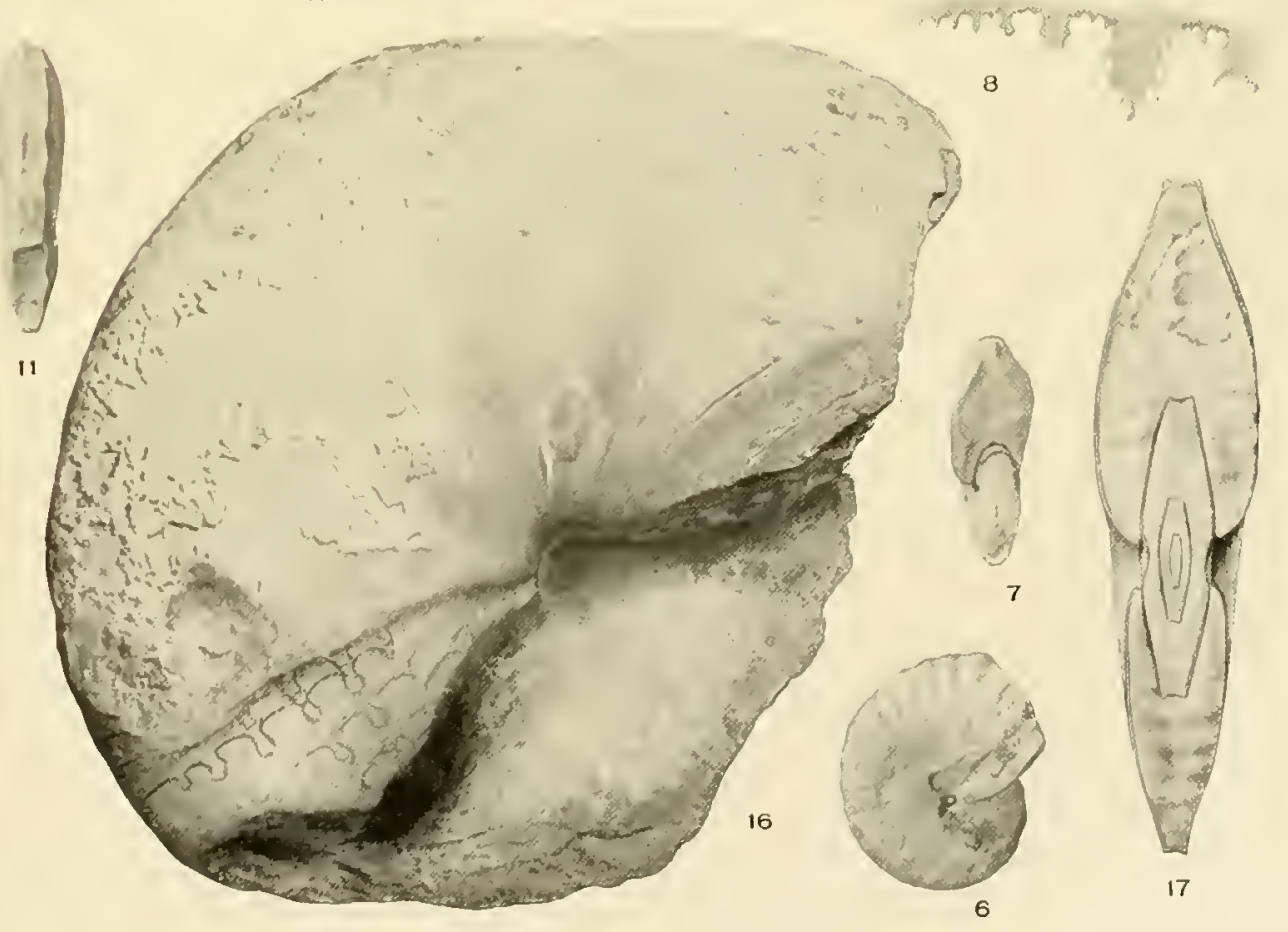

SUBPULCHELLIA NICKLESIA PULCHELLIA, KNEMICERAS, PROTENGONOCERAS. 

PLATE XVIII. 


\section{PLATE XVIII.}

\section{Kowmichas, Engonochian, Plomtexgonoceras.}

Figs. 1-3. Knemicerus gabli Hyatt.

Figs. 1, 2. Satural sizt. (After Galb.)

3. Lateral suture enlarsecs. (After Gabh.)

Quelorada de Huari, leru; Cenomamian?

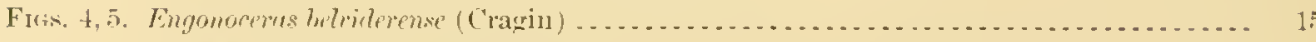

Fiss. 4, 5. Lateral and ventral views.

Belvidere, Kans: Washita ejoch: Coll. Cragin, Coloraro College.

Ficis. 6i-4. Protengonoceras plumum II yatt.

Figs. 6,7 . Lateral and ventral views, $\times 2$.

8 . Lateral sutnre, $X 2$; the anxiliary sarhlles Nos. 8 to 10 should be a tritle broader.

4. Iorsal suture of the same age, $\times 2$.

Texas. my collection.

286 

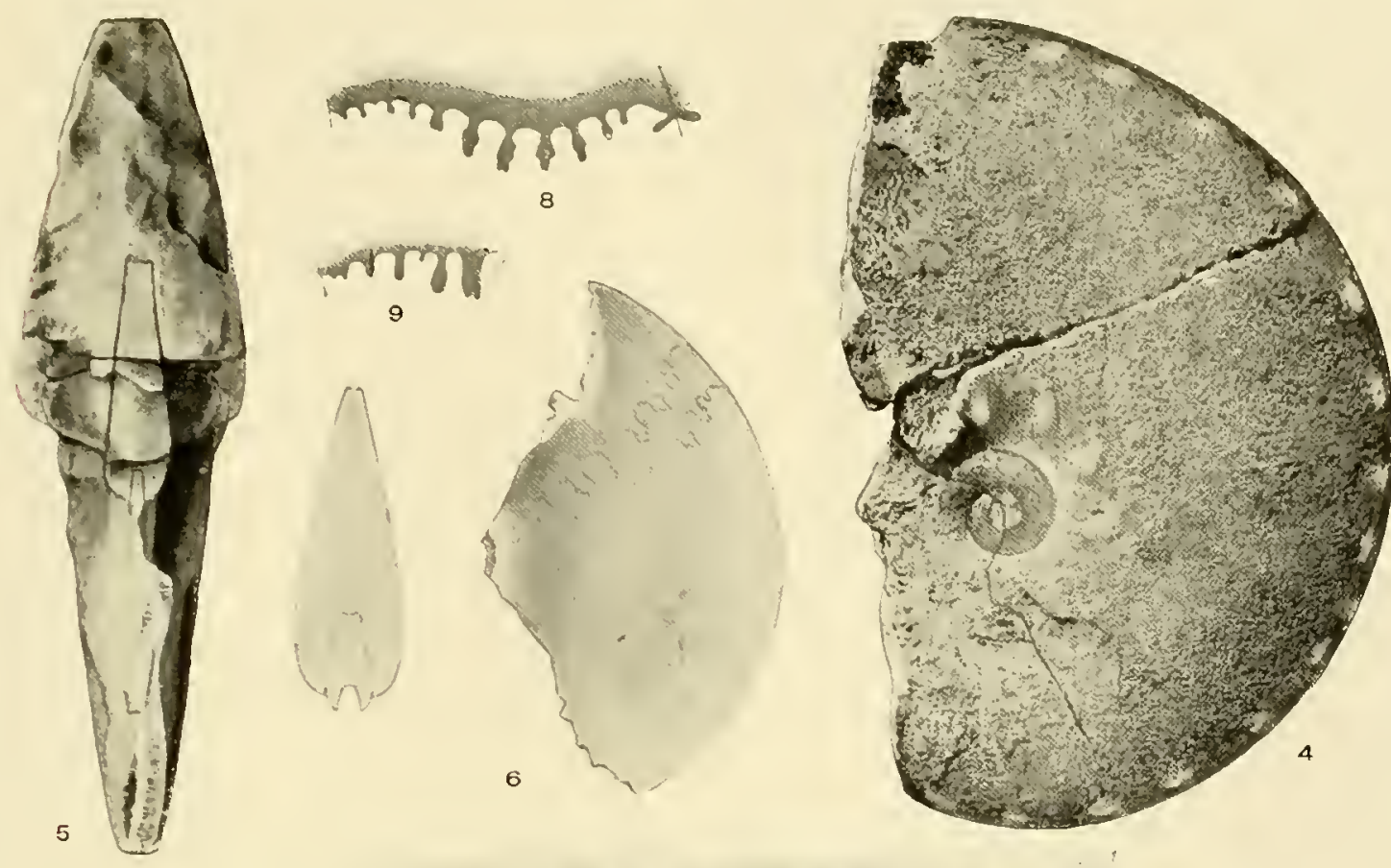
की
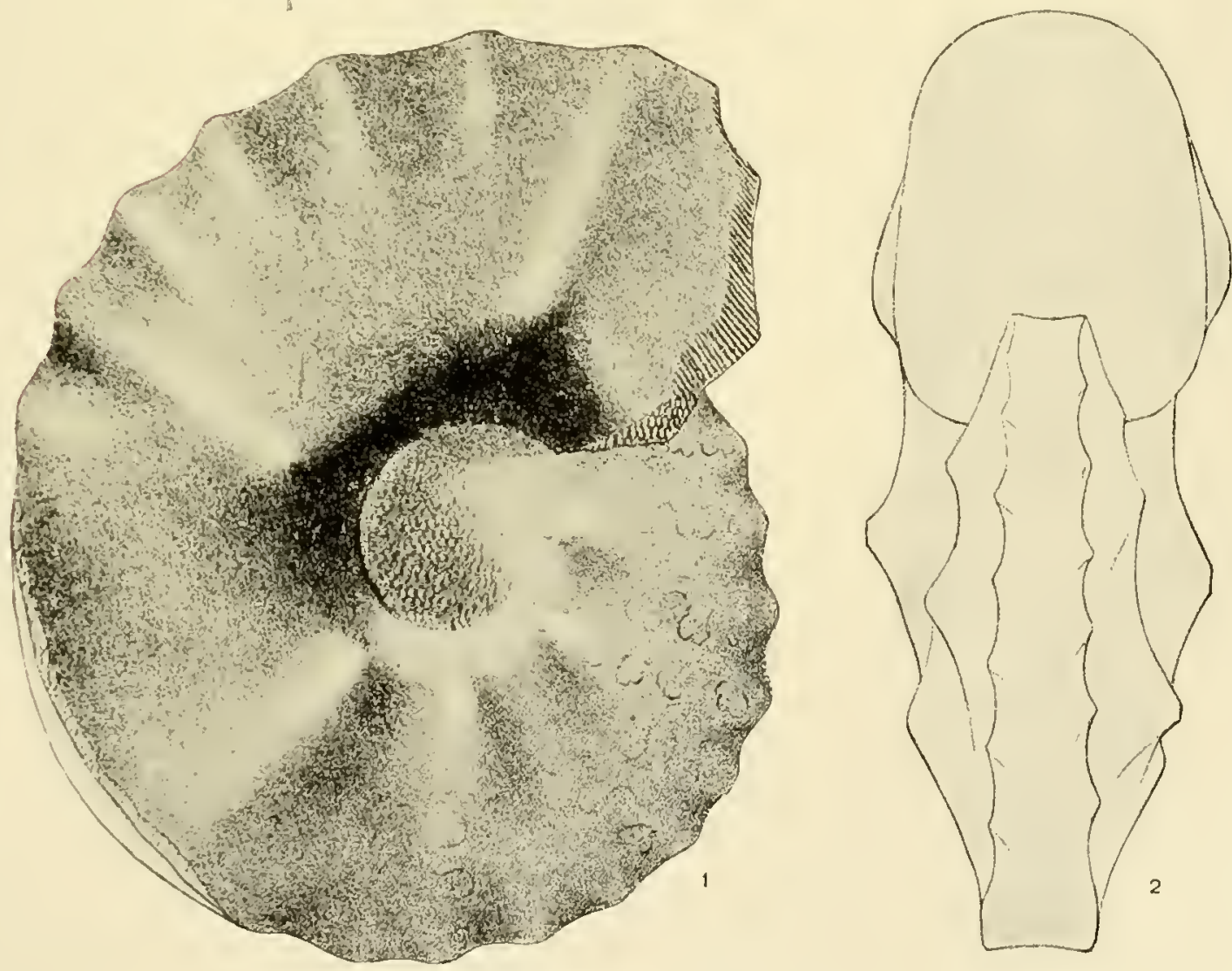

KNEMICERAS, ENGONOCERAS, PROTENGONOCEPAS. 



\section{PLATE XIX.}




\section{PLA'L XIX.}

\section{Fingonoceras.}

Flois. 1-ti. Jingouorepras uddeni (Cragin)

Figs. 1, 2. Type specimen from near Lintshorg, Kans., natural size.

3. Lateral suture of samt", slightly enlarged.

4,5. Speeinen from VcPheron Cunty, hans. Satural size, showing living rhamber nrobably almost complete along the umbilisal shoulder and about one-half of a volntion in length. The crease on the sirle of the venter of fig. 5 is an acrilent rlue to rmuresiom. Coll. I.S. Nat. Mlas.

6. Lateral suture of opposite or loft side, $\nless 21$. The curvature is somewhat less than it is on the specimen.

Kiowa shales, Comandhe serice, buwer ('retacens; my collection.

Frtis. 7-14. Engonocerts serpentimem (Cragin) . . . . . . . . . . . . . . . . . . . . . . . .

Figs. 7,8 . Natural size, living wamber one-half of a volution probably nearly eomplete on umbilial shulder. The venter of inner volution of fig. 8 is recilledly concave.

4. Lateral suture, $\times:$.

10. Part of sutures of yomg fragnent, $x \stackrel{2}{2}$. This specinum is trm rear Thenison, Tex.

11. Variety with brial ends to the custat and arowled perolian sutmes.

12. Lateral sutures, $\times 2$.

13. Ventral riew of 'ast, with similar coster.

14. Suture of same more like those of tig. 9. This is nut the to differener of age. The last 5 aul half of sixth saldle are dortal.

Four and one-halt miles northeast oi ciainesville, Tex., Denison; Washita epoch; Coll. I. S. Geol. Survey.

Fisis. 15-17. Engonoceres referdum Hyate" . . . . . . . . . . . . . . . . . . . . . . . . .

Fig. 15. Natural size, showing the late age at which the venter remains angulated, flat, and withunt tubercles. The romuled venter of the older stage is in fart lue to abrasion.

16. Shows what was seen of the lateral sutures.

17. Ihrsal suture of same agi as oldest suture on fig. 16.

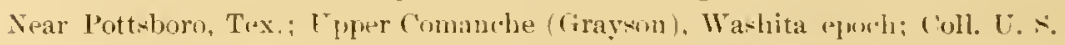
(iecol. simer.

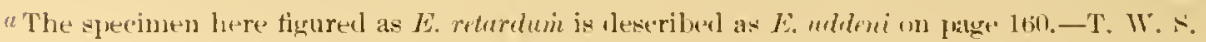
290 


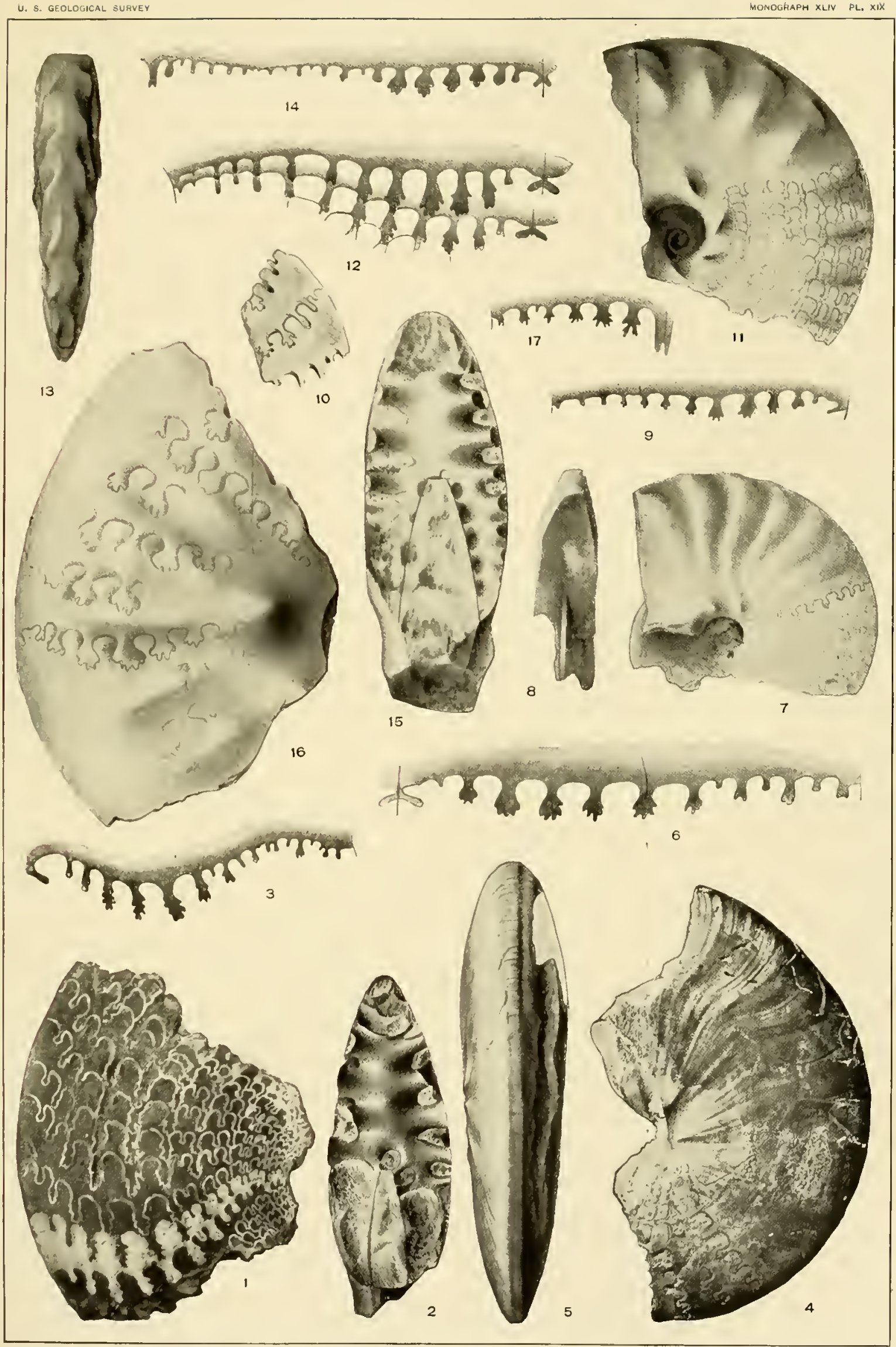



PLATE XX. 


\section{PLATE XX.}

\section{Exionoceras.}

Page.

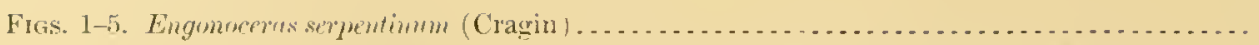

Fig. 1. Suture showing all of one sile, part of the other and dorsal suture, $X 2$.

$2,3,4$. Three views of one of ('ragin's figured types.

万. Suture of same. $X \ddot{2}$.

Sear Denison; Washita eposh; Coll. Cragin, Coloralo College.

Ficis. 6-13. Eugonoceres prerdiute (ron buch) -

Figs. 6. 7. Specimen from Towash, Twx.; Coll, Mus, Comp. Znol., Cambrilge.

8. Suture of samie, $x: 2$

4. 10. Specimen from near Cerrogordo, Ark.; Coll. I. \&. Nat. Mins. No. $226+3$.

11. Suture of same, natural size.

12. Specimen from Seren Knobs, 5 nilles southeast of Glenrose, Tex.

13. Suture of same, $\times 2$.

Fredericksburg group, Comanche series. 


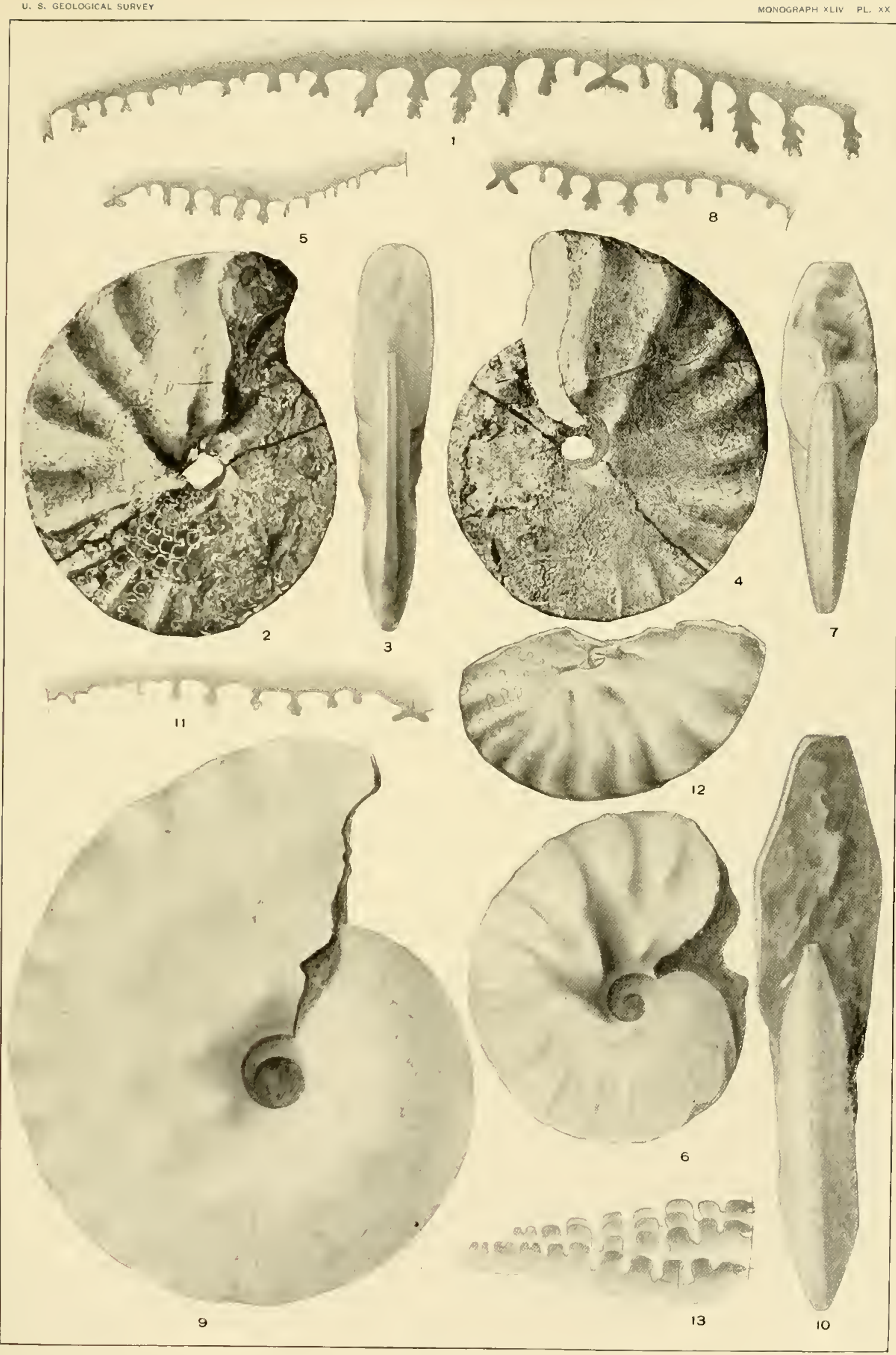

ENGONOCERAS 

PLATE NXI. 


\section{P L A T E X X I.}

\section{Eingovochisas.}

Fir. 1. Engonoceros pierdenale var. rommun Hyatt. . . . . . . . . . . . . . . . . . . ...

Coll. L. S. Yat. Mus., Yo. $\$ 301$.

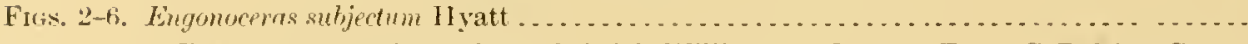

Figs. 2,3. A specimen from Gabriel, Willianson County, Tex.; Coll. Mus. Comp. Zool., Cambridge.

4. Portion of septum of same sperimen-the middle one of the three indistinctly shown in fig. $2, \times 2$.

5. Last septum of same specimen, $\times 2$.

6. Septum of a smaller specinen from same locality, $X 2$. Washita (?) group, Comanche series. 

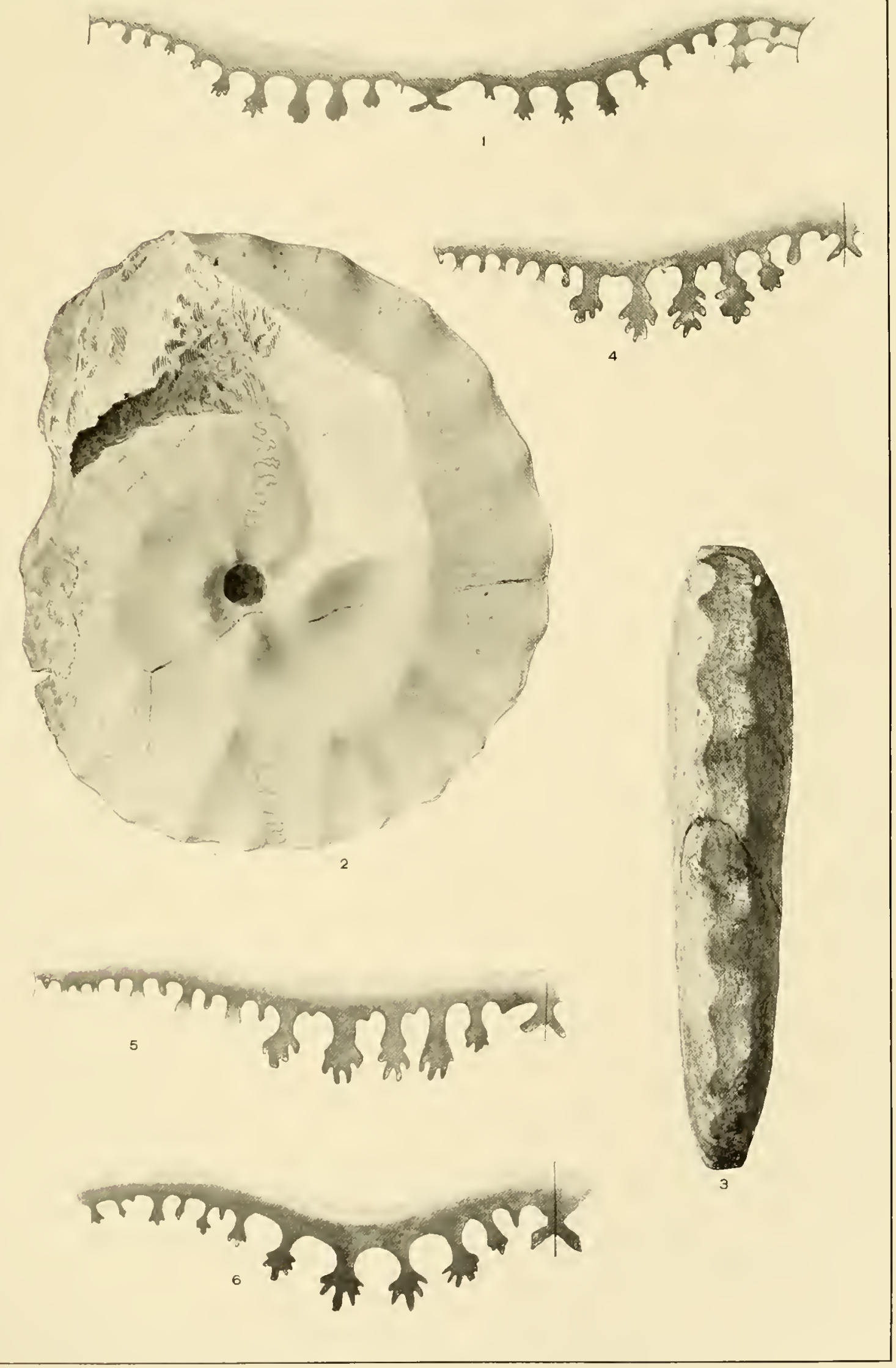

ENGONOCERAS. 

PLATE XXII. 


\section{PLATE XXII.}

\section{Engionoceras.}

FiGs. 1-5. Engonoceras suljcctum Hyatt ..........................................

Fig. 1. Specimen from Duck Creek beds, near Denison, Tex.; Coll. U. S. Geot. Surv.

2. Suture of same, very slightly abraded, $\times 2$.

3. Slecimen from Graysun, Tex.; Coll. D. S. Martin.

4. Suture of same, $\times 2$.

5. Siture of ipecimen from Tarrant Connty, Tex.; Coll. Cragin, Colorarlo College.

Washita (?) group, Comanche series.

Ficis. 6-10. Engonocores gildusum Hyatt

Fig. 6. Lateral view of a small specimen from Goodland limestone, 15 milee west of Lenison; Coll. L'. S. Geol. Surv.

7. Ventral view of aame, partly restorerl.

8. Septum of same, $\times 2$.

9. Fragment doubtfully referred to the species, from Bell County, Tex.: Coll. T. S. Nat. Mus, No. S301a, $\times 2$.

10. Septum of sante, partly restored, $\times 2$.

Fredericksburg group, Comanche series. 


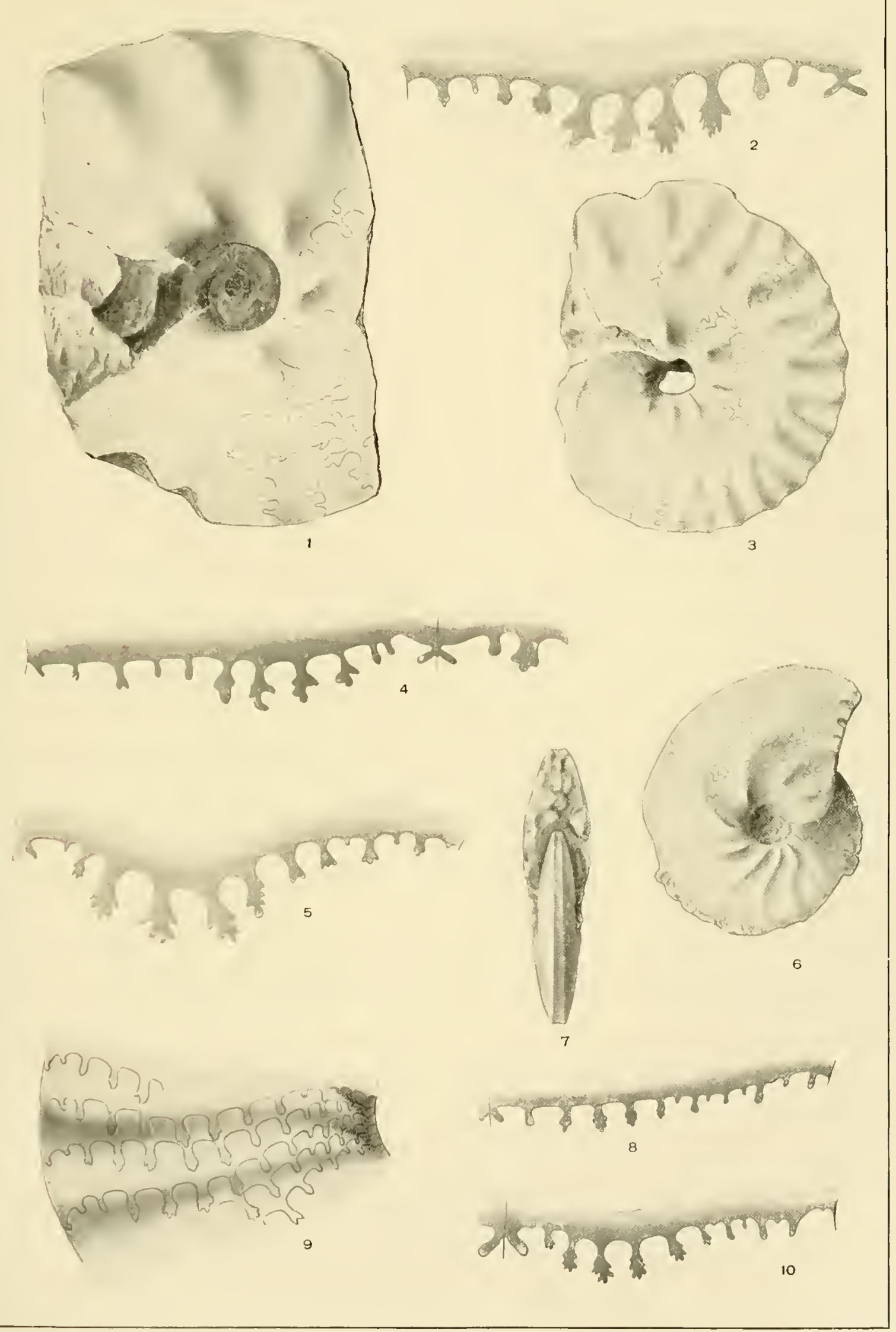

ENGONOCERAS. 

PLATE XХTI. 


\section{PLATE XXIII.}

\section{ENGOSOC TRAS.}

Ficis, 1-6. Engommerus gibbrsem Hyatt.

Figw. 1, 2. Specinen from Cook County, Tex.; my collection.

3. Suture of same, $\times 2$.

4,5 . I framment from the Goodland linestone, 15 miles southwest of Gainesville, Tex.

b. Suture of same, $\times 2$.

Frerlericksburg group, Comanche series.

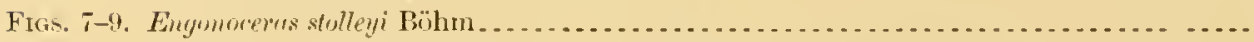

Figs. 7, S. Young specimen in Cragin Collection, Colorado College.

9. Suture of same, $\times 2$.

Frelerick-burg group [?], Comanche series.

295 


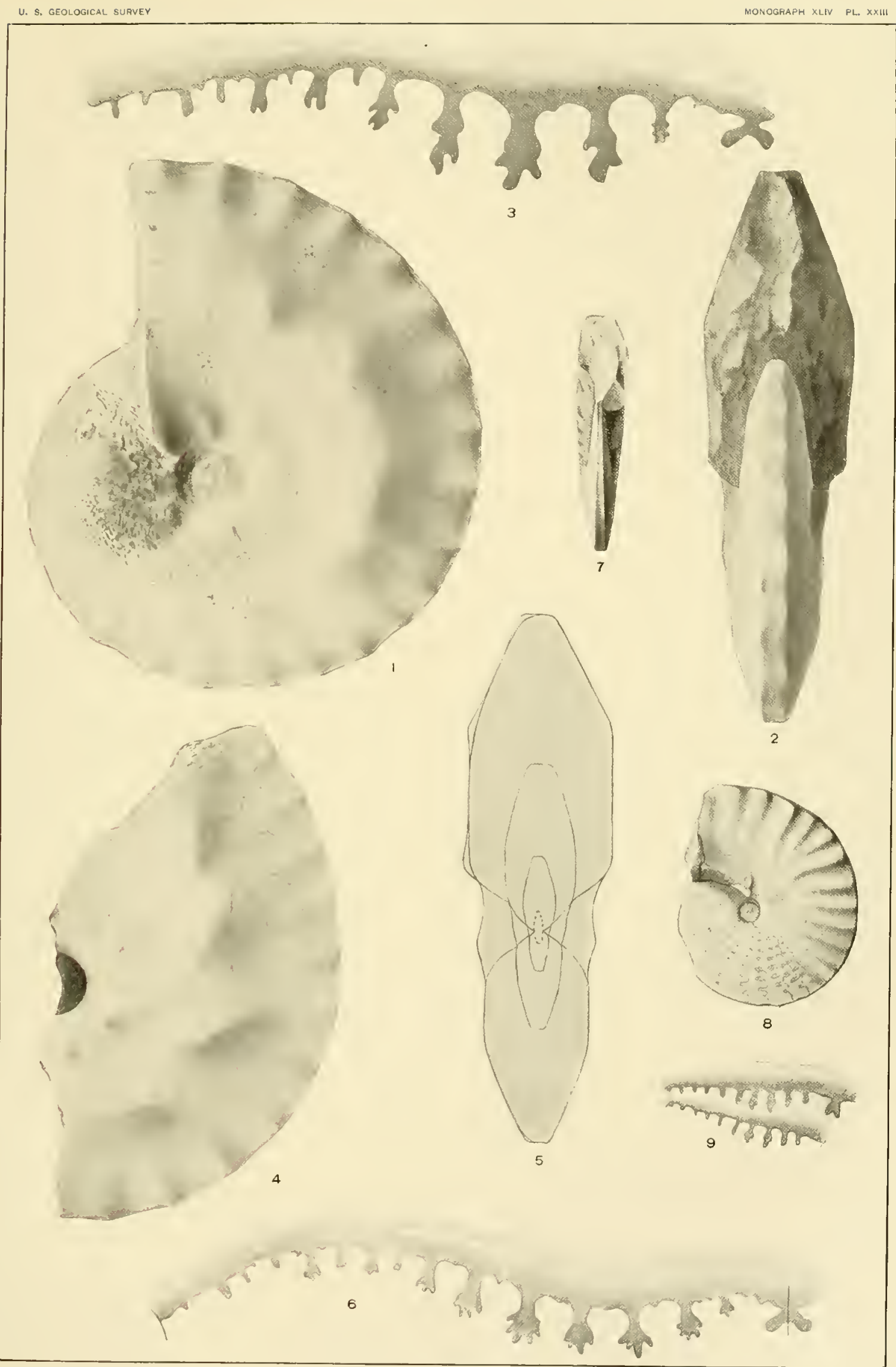





\section{PLATE XXIV.}




\section{PLATEXXIV}

\section{Exgonoceras.}

Fiss. 1-5. Engonocerus stolley Böhm.........................
Figs. 1, 2. Epecimen in uy collectinn, partly restored.

3, 4. specimen in Coll. Hill, IT. S. Geol. Surr. ["Hill ta."] (?)

5. Suture of same, $x ״$. This is somewhat worn down.

Fredericksburg group [?], Comanche series.

FIss. 6-8. Engonoreras complicatume Hyatt

Figs. 6, 7. Type specimen from near Austin, Tex. Coll. Hill, U. S. Gieol. Surv.

8. Suture of same, $\times 2$.

Comanche Peak limestone of Fredericksburg group, Comanche series. 


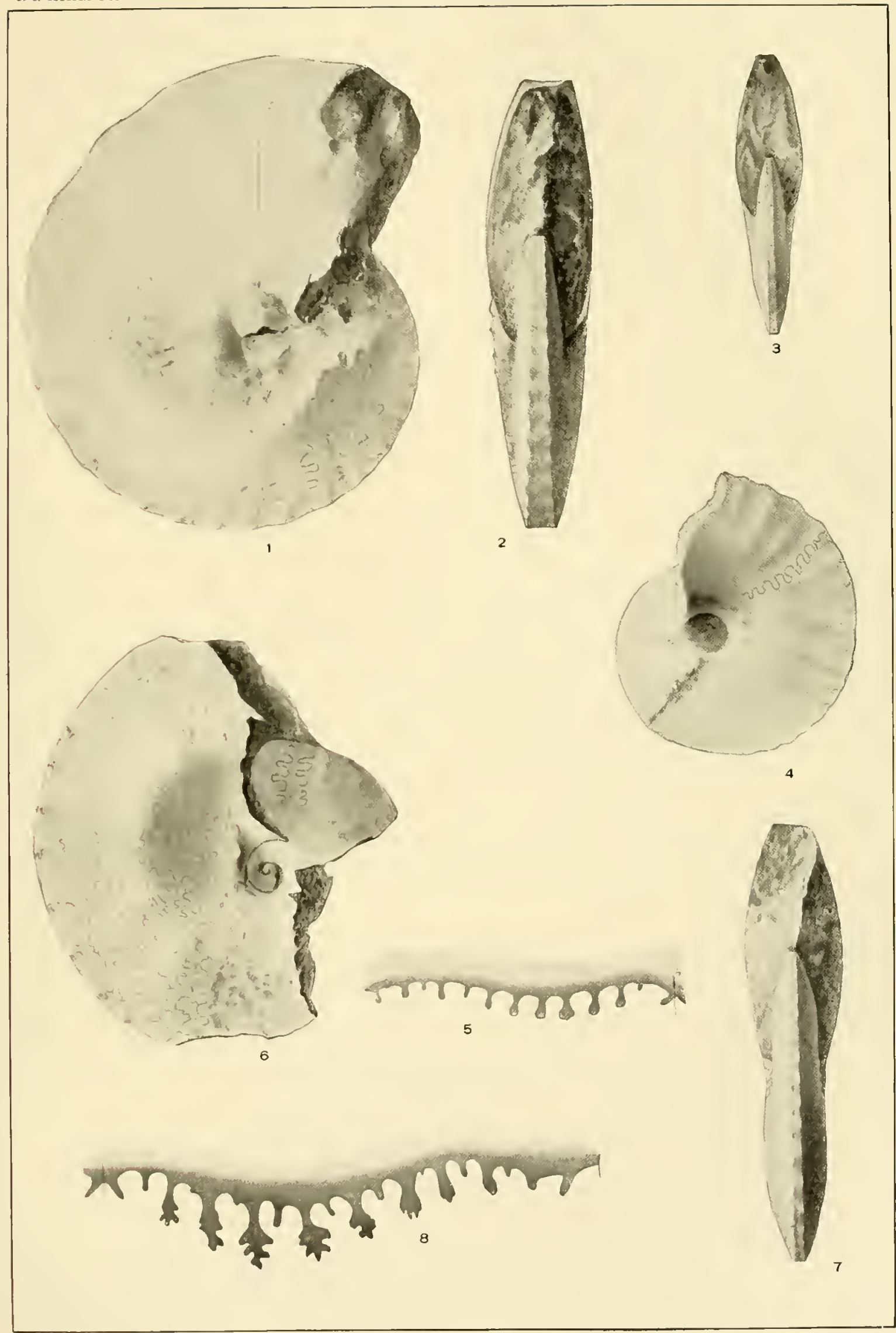



PLATE XXV. 


\section{PLATE XXV.}

\section{Neolobites, Meteigonoceias.}

Firis. 1, 2. Copies of Choffat's figures 3a, 3b, published as N. ribrayeanus.

3,4 . Suture of probaloly the same necies (after Choffat).

Cenounanian; Portugal.

Fugs. 5-9. Metengmoreras inscrithum Hyatt.

Fig. 5. Section of fragmentary specinen from west of Walnut springs, Texas. Cull. Cragin, Culorato College.

6. Suture of same, enlarged.

7. Suture of a small frammentary : precimen from 12 miles northwest of Decatur, Tex.; coll. IT. S. Geol. Surv.

8. Suture of fragment from 15 miles west of Denison, Tex.; Coll. L. S. Geol. Surv.

9. Ventral view, partly restored, of specinien from 1? miles northeast of Decatur, Tex. For other figures see Pl. XXVI.

Frellericksburs group, Conanche series. 


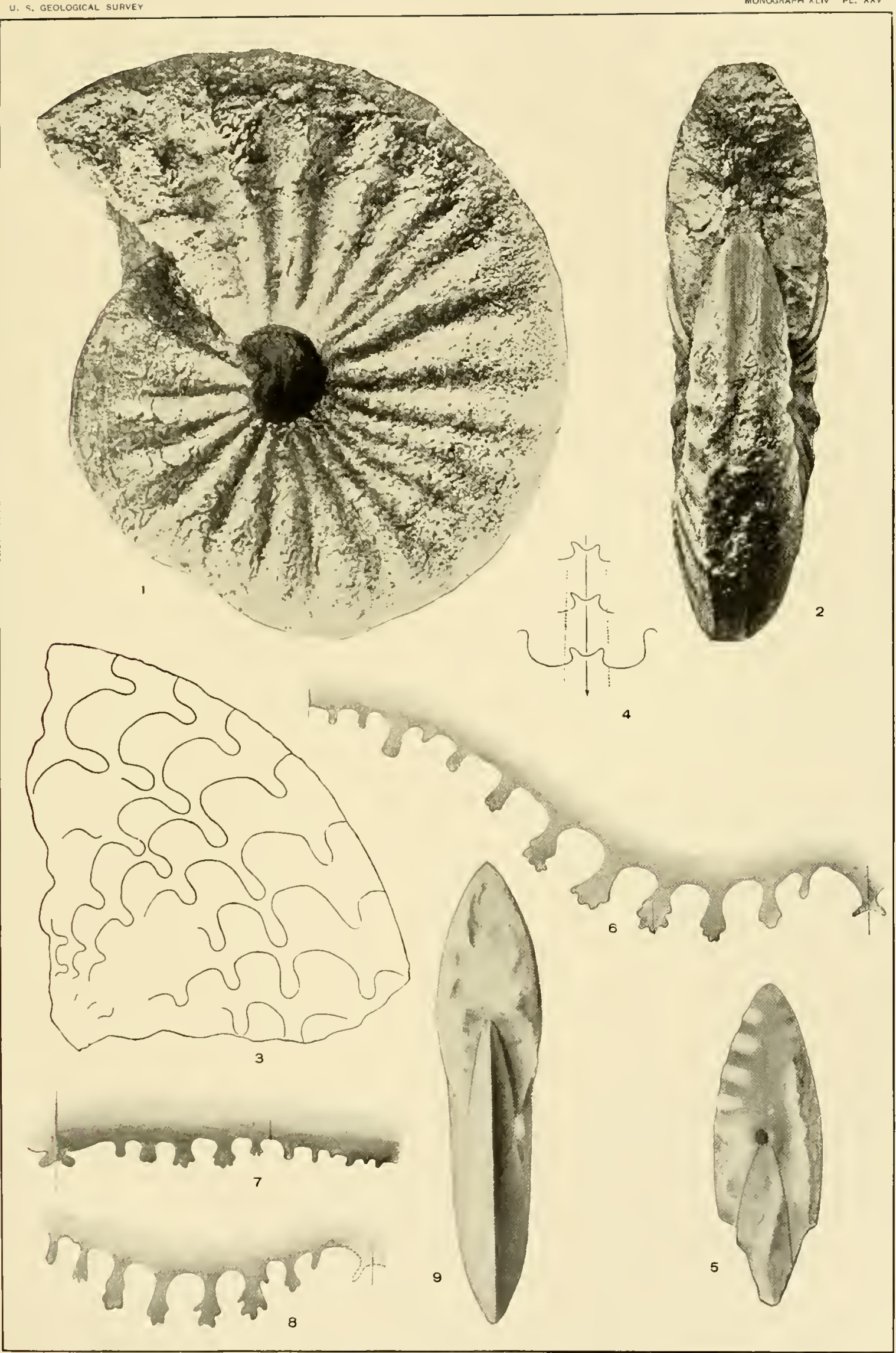



PLATE XXVI. 


\section{PLA T E X X VI.}

\section{Metengonoceras.}

FIGs. 1-1. Metengonoreras inscriptum Ilyatt. . . . . . . . . . . . . . . . . . . . . . . . . . .

Fig. 1. Enlarged suture of specimen represented by figs. 2 ancl 3, and by Pl. XXT, fig. 9.

2, 3. Specimen from 12 miles northeast of Decatur, Tex.

4. Suture of large fragment from y miles from Austin, on Beecaves road. Coll. T. S. Geol. Surv. [This drawing was labeled .1\%. ambigum, lout the specimen is deseribed under $\boldsymbol{M}$. inscriptum.-T. W. S.]

Frederick:burg troup, Comanche series.

Figs. 5-7. Metengonoerves ambiguum Hyatt

Fig. 5. Sirle view of type.

6. 7 . Sinture of same specimen, $\times 2$.

Nine miles from Austin, on Beecaves road; Fredericksburg gronp, Comanche

Peak limestone, Comanche series. Coll. U. S. Geol. Surv.

Fig. 8. Metengonocerts ucutum II yatt

Side riew of fragmentiry type specimen.

Elm Fork, Dallas County, Tex.; probably Eagle Ford shales, Upper Cretaceous. Coll. Mus. Comp. Zool., Caubridge. 


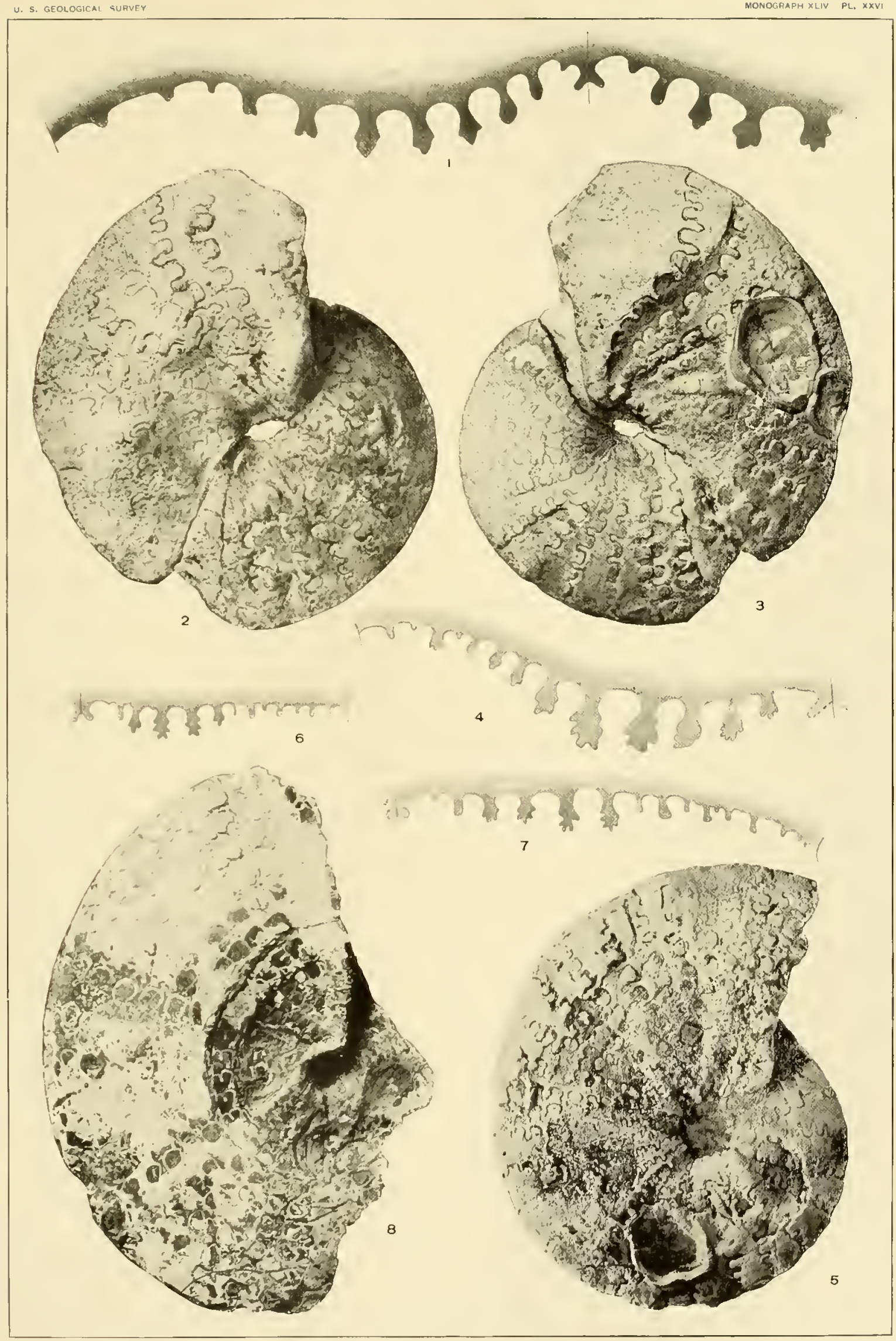

METENGONOCERAS. 



\section{PLATE XXVII.}




\section{PLA TH XXVIT.}

\section{Metengonochis. Placentichas.}

Page.

Finis. 1-2. Meten!monocress acutum Hyatt.

Fig. 1. Ventral view of type specimen.

2. Septum of same, $\times 2$.

Elm Fork, Lallas County; Tex, probahly Lagle Ford shales, I puer Cretacents. Coll. Mus. Comp. Zool, Cambriıge.

Fiss. 3-1 1t. Metengonoceres dumbli (Cragin).

Figs. 3,4. Lateral and ventral views of specimen described.

5. Section of same.

6. Inner whorls of fig. 5, enlarged.

7. Center of same, still more enlarged, whwing antisiphonal lobe, the innermost whorls having dropjerl out.

8. Section of whorl in neanic stage, $X 10$.

9. Adult lateral snture, $\times 2$.

10. Last lateral suture, $\nless 21$.

11. Dorsal suture continuous with fig. 9, enlargerl.

12. Dorsal suture one-fourth volution older than fig. 11, enlargerl.

13. Lateral and part uf torsal suture of neanic stage, $\times 18$.

14. Dorsal suture of somewhat later substage than fig. 13, enlargerl.

Four miles east of Whiteshor, Tex, Fagle Furd shales, Lpper Cretaceous; Coll. U. S. Genl. Surr.

FIt:s, 15-17. Mluermtireress syitule (Morton)

Fig. 15. Suture of the type in Coll. Acarl. Nat. Sei. Phila.

16. Lateral suture of var. hulei, Coll. Bost. Foe. Nat. Flist., No. \$ist.

17. 1hrsal suture of oleler part of same volution as fig. I6.

Greene County, Ala.; Entaw hesls (?), Epper Cretaceous. 


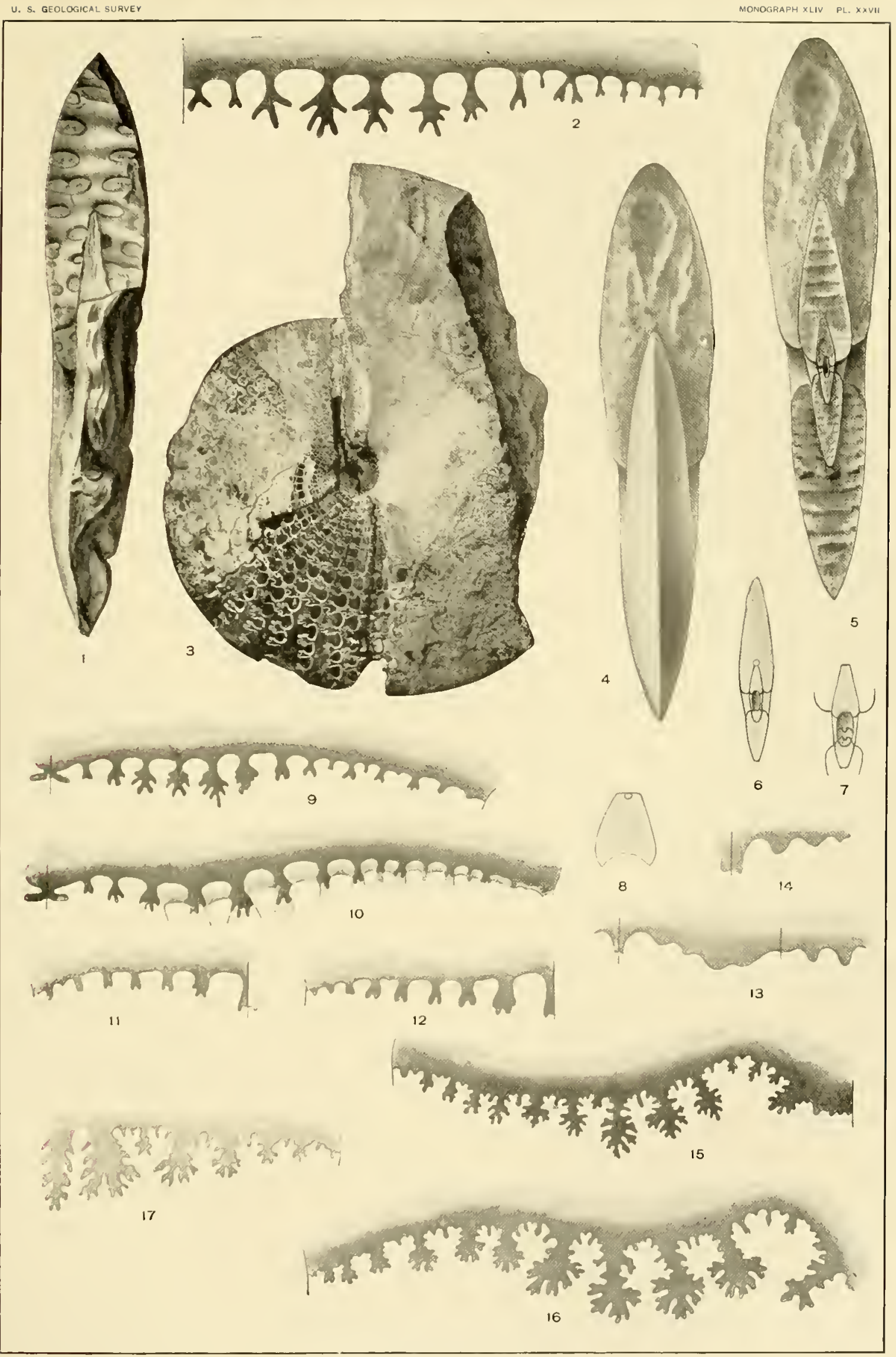

METENGONOCERAS PLACENTICLRAS 

PLATE AXVIII. 


\section{PLATE XXYII.}

\section{Placenticeras smptale: (Morton).}

(Page 205.)

Figs, 1, 2. Two views of the type, Coll. Aral. Nat. Sci. I'hila. (For suture, see Pl. XXYII, tig. 15.)

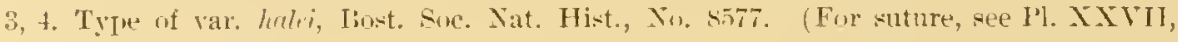
fige. 16 ant 17.)

5, ij. Another werimen of var. halei, same collention.

Futuw leels ("), Tpper Cretacens, Greene Countr, Aliz. 308 


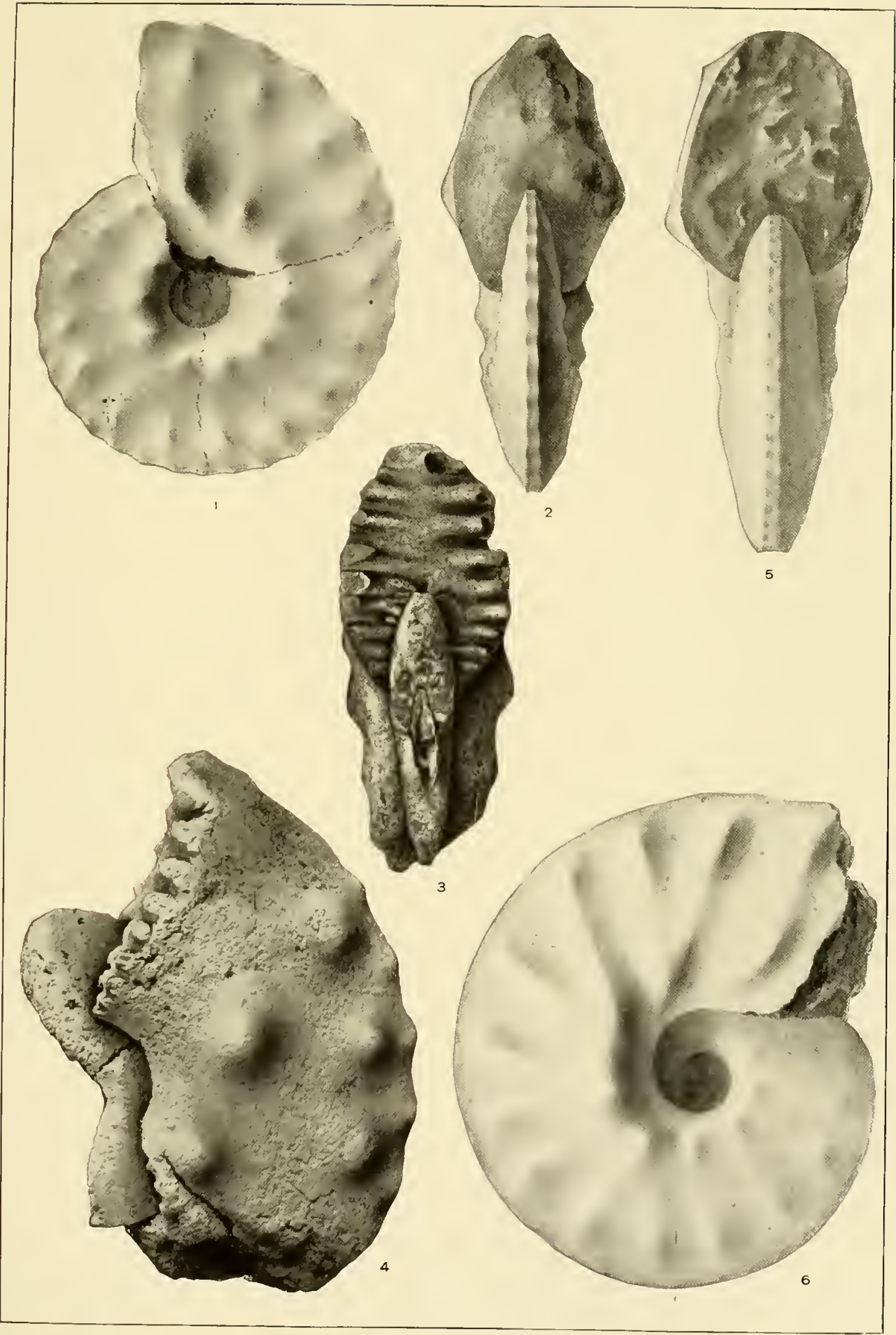

PLACENTICERAS. 



\section{PLATE XXIX.}




\section{PLATE XXI.}

\section{Placenticeras auadalupe (Roemer).}

Fig. 1. Lateral riew of a large specimen.

(l'age 197.)

2. Aperture view of same considerably restored.

3. Section of same.

4. Enlarged rection of inner whorls of same.

Sear fort Worth, Tex.; Taylor beds ("); Upuer Cretaceous; my collection. 310 


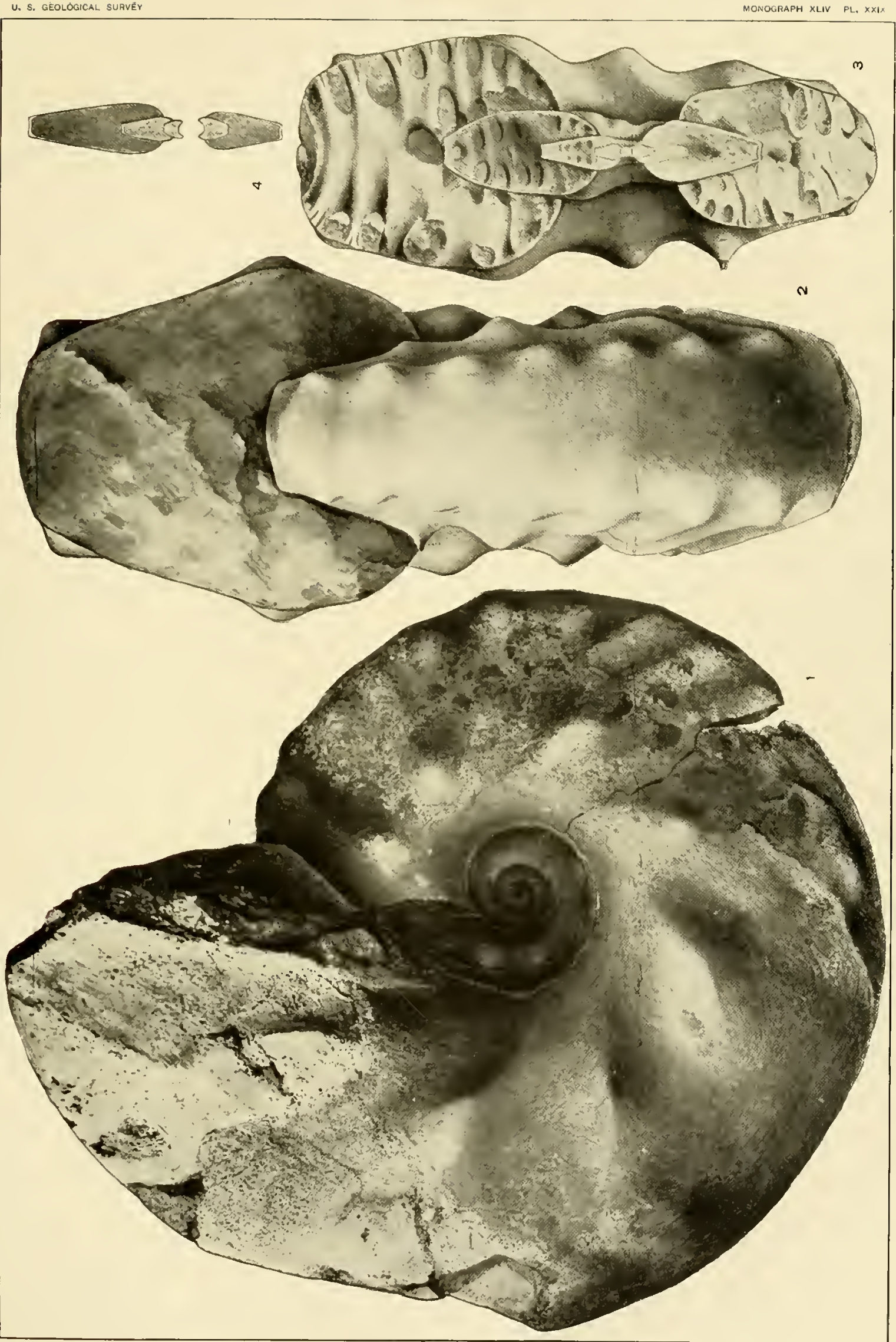





\section{PLATE XXX.}




\section{PLATE IXX.}

P'tacenticeras saycarlosexse Hyatt.

(Page 200.)

Fig. 1. Side view of an average-sized specimen

2. Alerture view of same.

3. Suture of same, $\nless 2$.

San Carlos, Presidio Connty, Tex.; San Carlos beds: Upper Cretaceous; Coll. U. S. Geol. Snrv. 312 


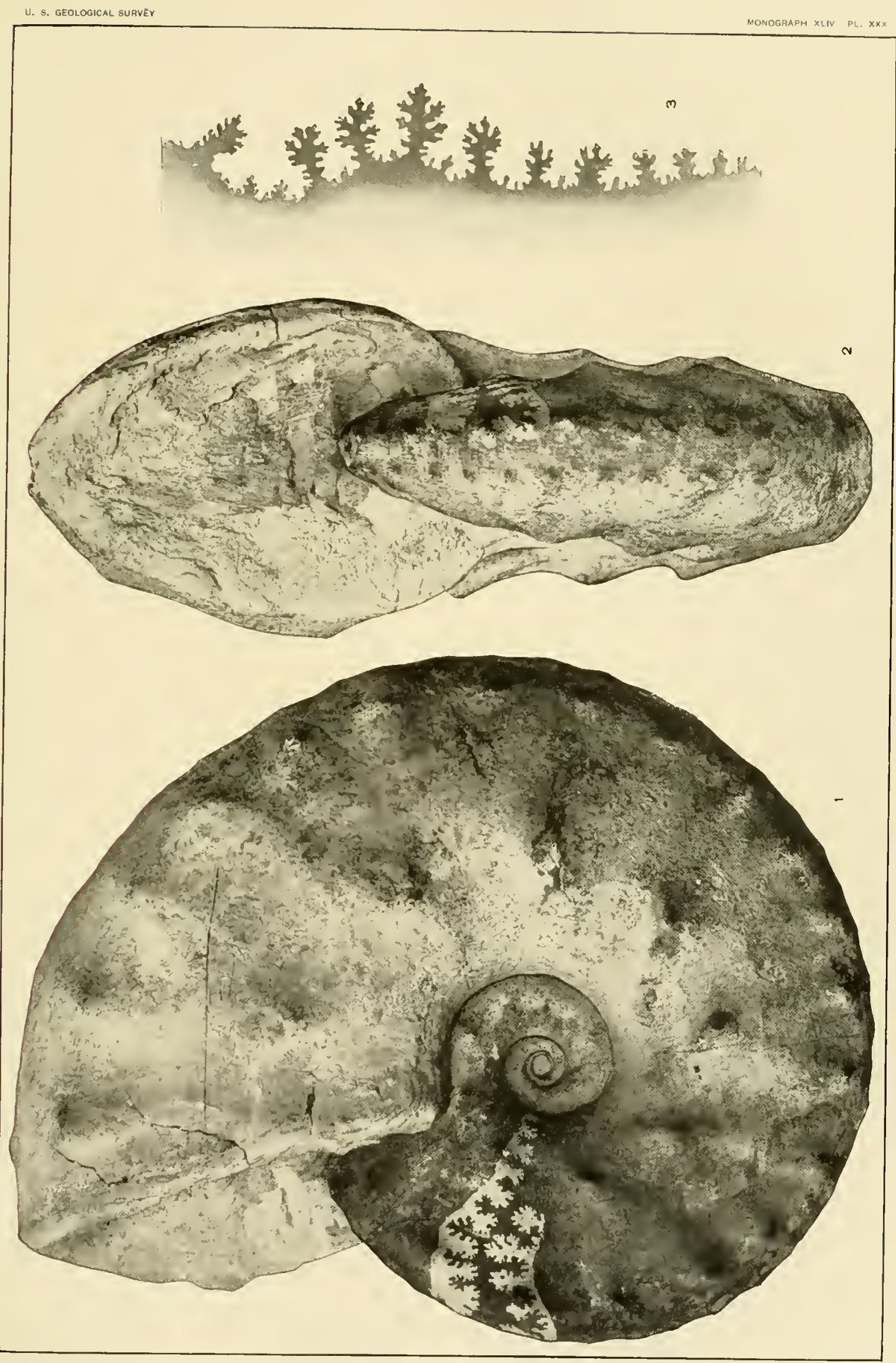

PLACENTICERAS. 

PLATE XXXI. 


\section{PLATE XXXI.}

\section{Placenticeras.}

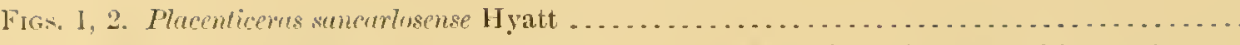

Fic. 1. Section of a small specimen-"prssage form between this species and gualalupar."

2. Sicle view of same.

San Carlos, Presidio County, Tex.; San Carlos betls, Upper Cretacenus; Coll. L'. S. Geol. Surv:

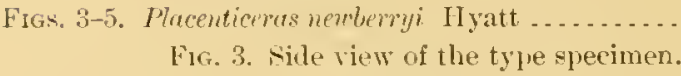

t. Section of same.

5. Aperture view of same.

Neal I'resilio Del Norte, Chihuahua, Mexica; San Carlos beds, Upuer Cretaceous; Goll. Columbia Tniversity, No. 10073G. 


$$
8
$$



PLATE XXXII. 


\section{PLATE X X X I I.}

Placexticeras saxcardosexse var. pseudosyrtal. Hyatt.

(Page 200 .)

Side view of type of variety (see I"l. XXXIII, fig. 1).

Near Fort Worth, Tex.: Taylor heds (?), LPper Cretaceous; my collection. 316 


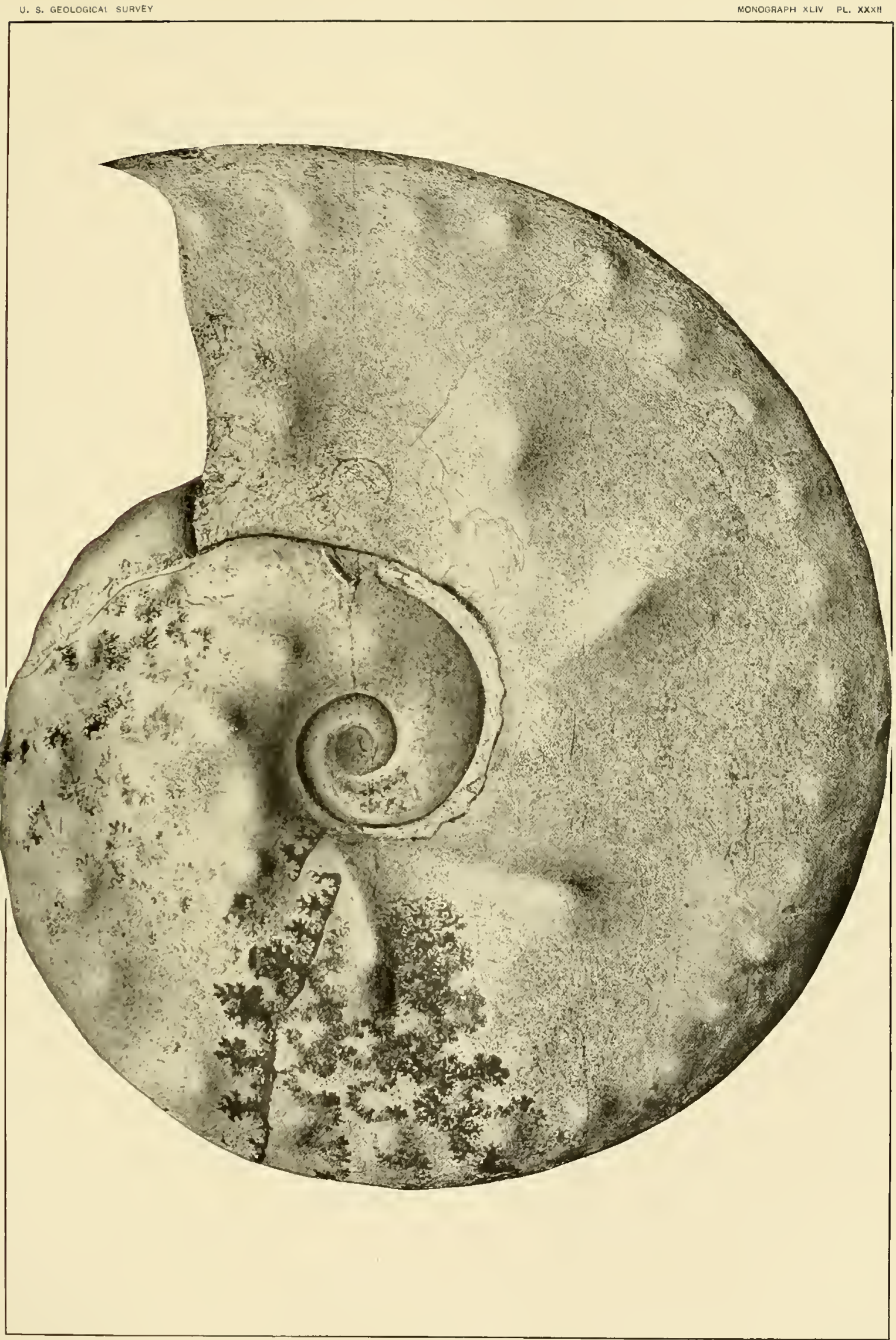

PLACENTICERAS 

PLATE XXXIII. 


\section{PLATE XXXIII.}

\section{Piacentictimas.}

Fici. 1. Placenticeras sunenrlosense var. psendosyrtnle II yatt

Fig. 1. Aperture view of specimen figured on H. IXXII.

Fisis. 2-4. Placenticeras planum IIyatt

Fig. 2. Aperture view of melium-sized specimen partly restored.

3. Sille view of same.

4. Peripheral view of another specimen showing less development of noles. (See I'l. XXXI, fig. 1.)

San Carlos, Presidio County, Tex.; Sin Carlos beds, Upper Cretaceous; Coll. [. S. Fienl. Survey. 


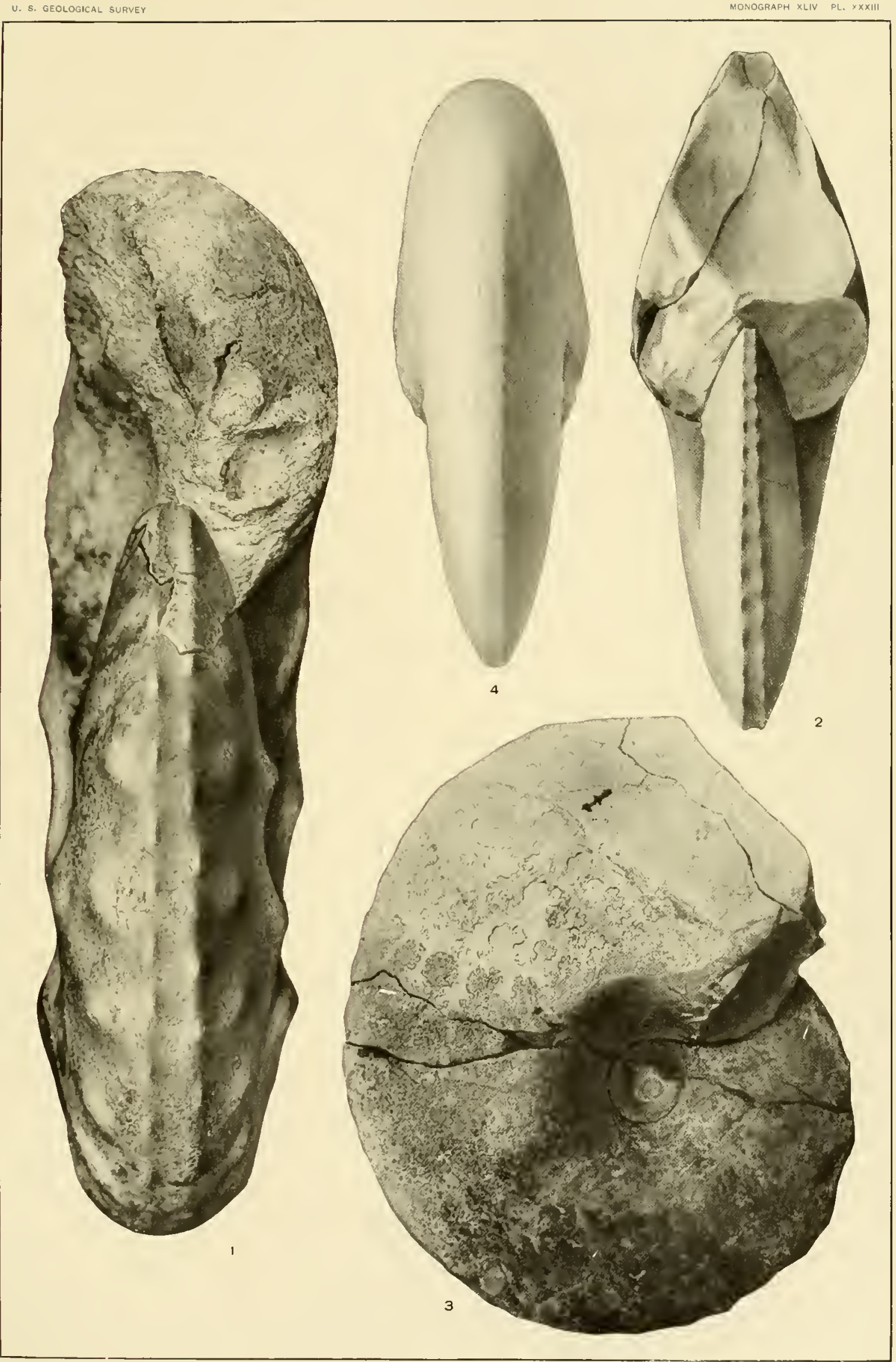

PLACENTICERAS. 

PLATE XXXTV. 


\section{PIATE XXXIT.}

\section{Placesticerat plasem Hyatt.}

(Page 202.)

F1G. I. Sille view of the small specimen represented by Pl. XXXII, fig. $t$. 2, 3. Apreture and side views of a larger specimen.

San Carlos, Presidio County, Tex.; San Carlos leds, Lpper Cretaceus; Coll. L. S. Geol. Survey. 320 


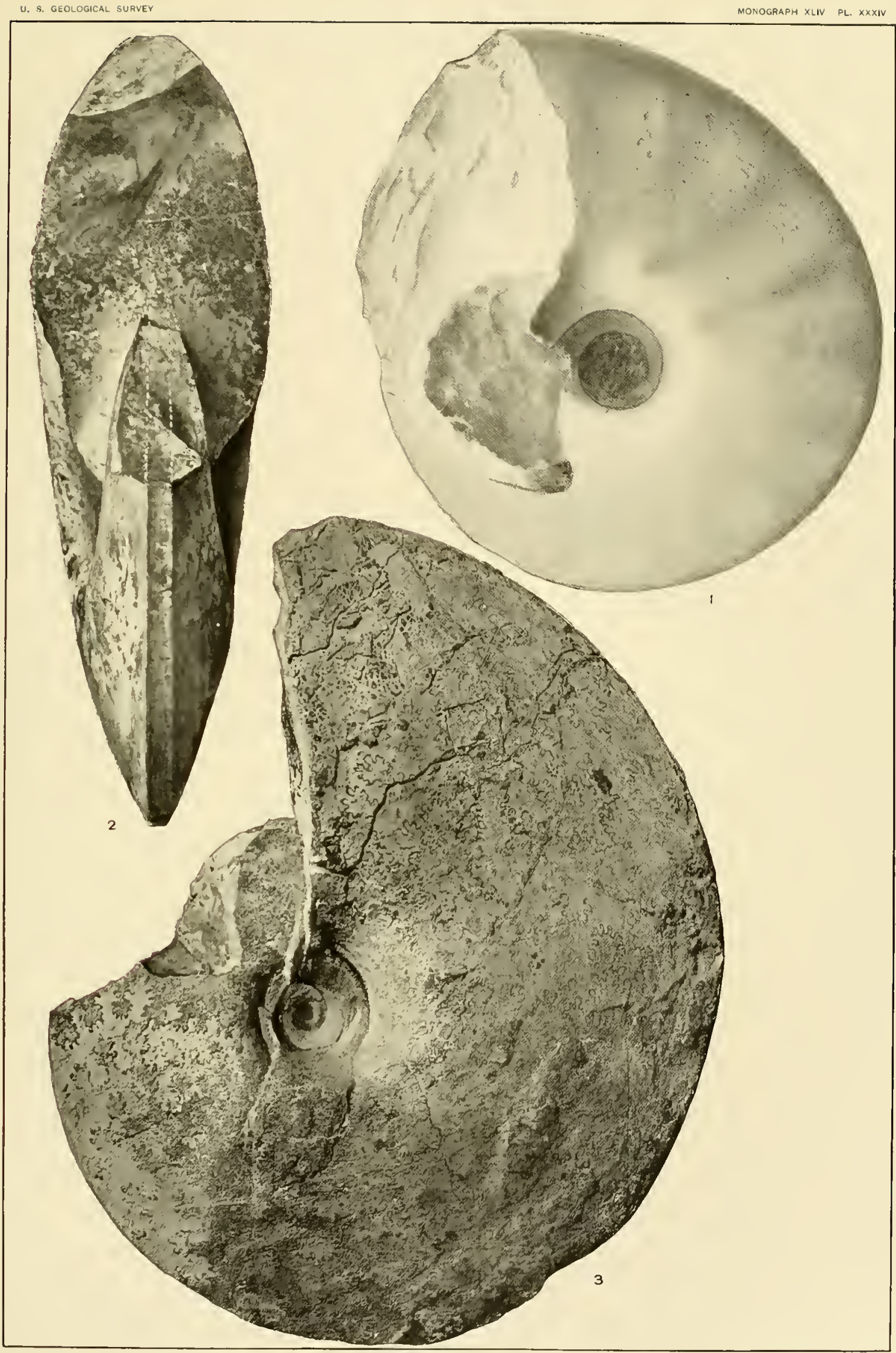

PLACENTICERAS 



\section{PLATE XXXV.}

yox XLIV-03-21 
PLATE XXXY.

Placenticeras intercalare Meek.

(Page 207.)

Firis. 1, 2. Sile and aperture views of melium specimen (see Pl. XXXYI, fig. 1).

[Black Hills.], Fort Pierre, Upper Cretaceuns; Coll. Yale University No. 1863. 


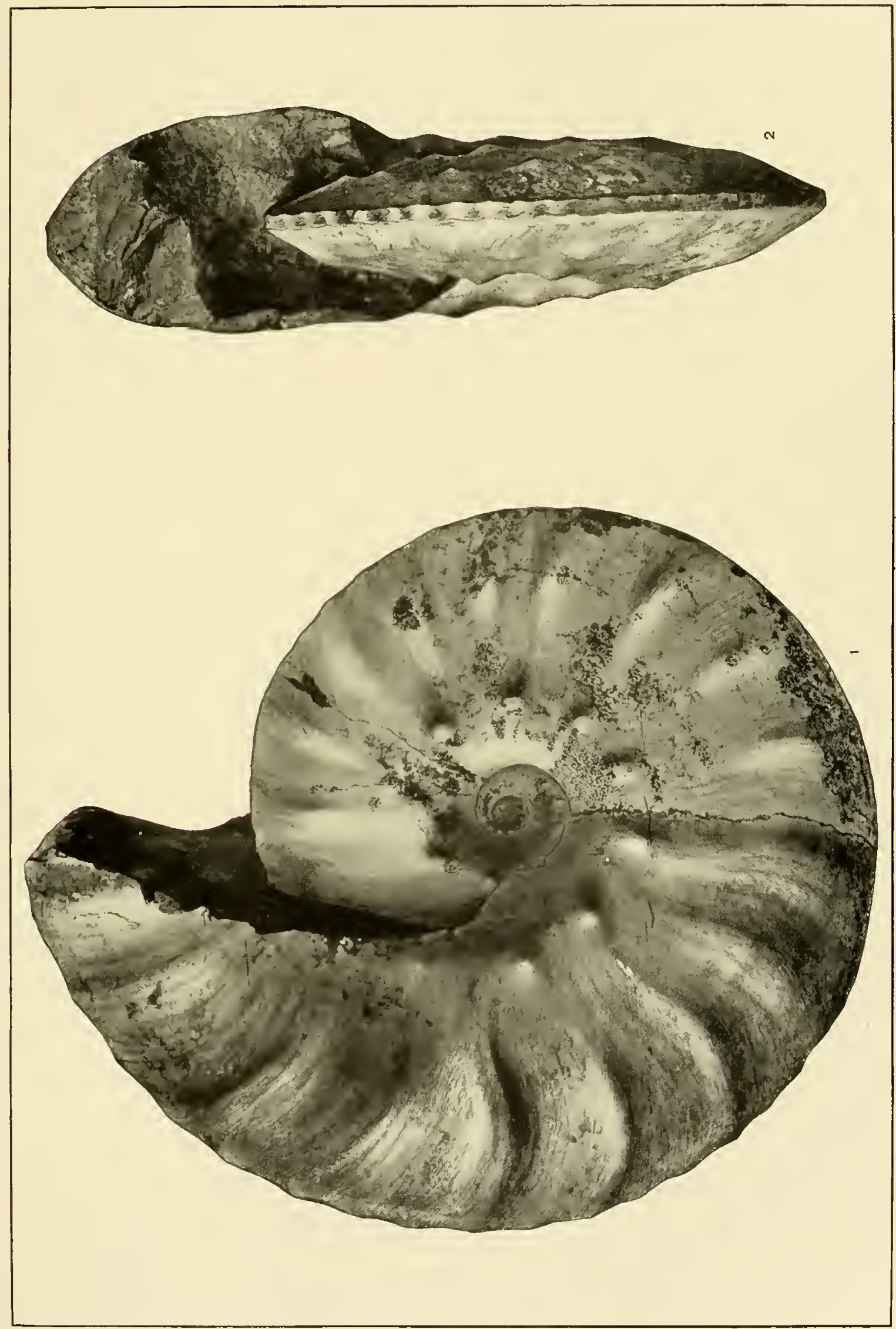

PLACENTICERAS. 

PLATE NXXVI. 


\section{PL, A TE XXXVI}

\section{Plachaticeras intercalare Meek.}

(Page 207.)

FIci. 1. Opunsite side of specimen figured on Pl. XXXY.

2. 3. Sille and aperture views of small specimen, No. 2104l).

t. Suture of same, $\times 2$.

5. Parts of two septa of Geological survey specimen from Ilarper, Wyo., representerl ly 1', XXXTII, figs. 1, 2.

Fort l'ierre, Upuer Cretaceous, Coll. Yale I"ni versity (except fig. 5). 324 


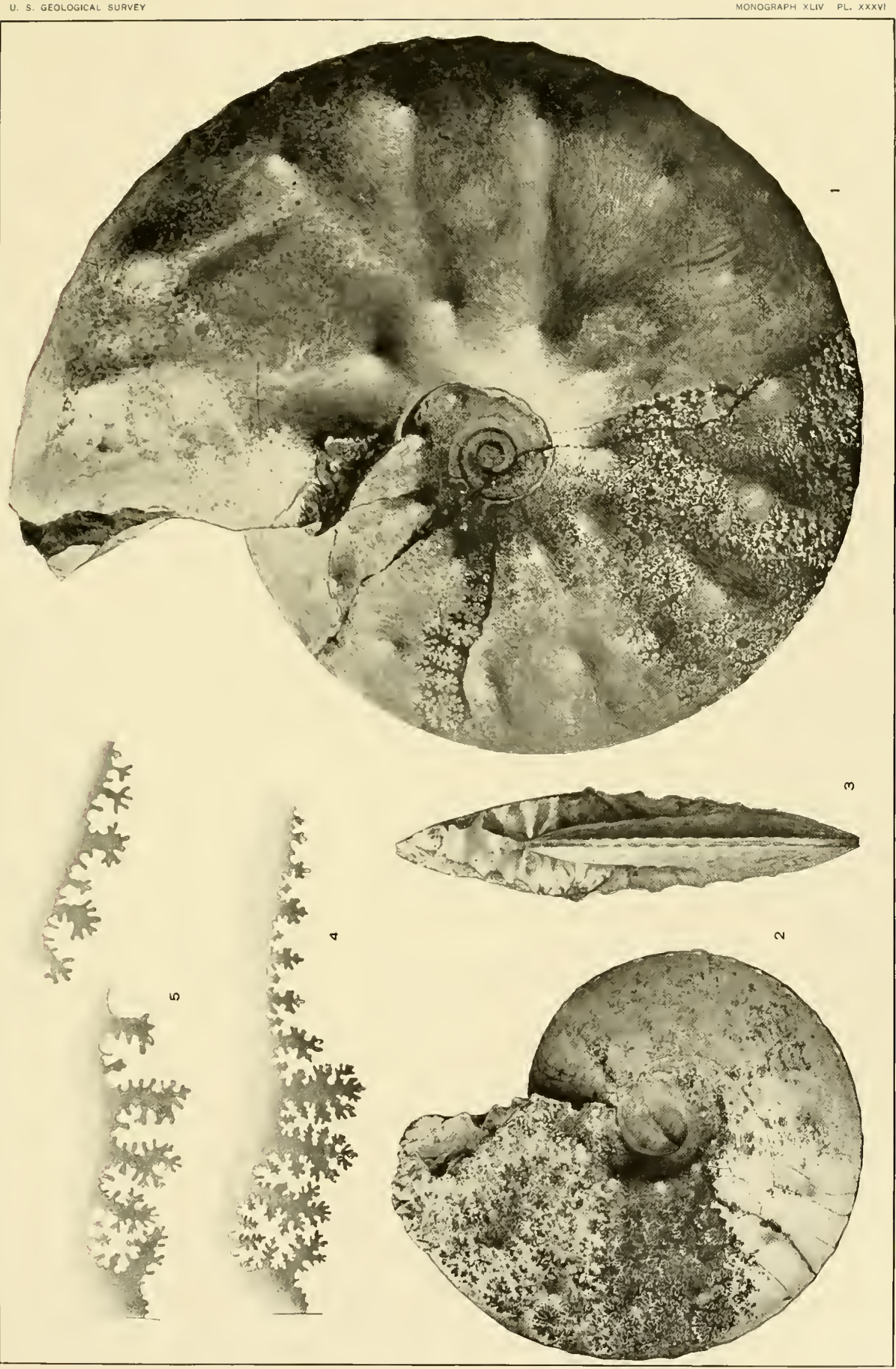

PLACENTICERAS 



\section{PLATE XXXVII.}




\section{PLATE XXXII.}

\section{Placestichlas interchladis Meek.}

(Page $20 \%$.)

Finis. 1. 2. Fragmentary small specimen from near Harper, Laramie Plains, Wyo; Coll. L. A. Geol. Survey. (see I']. AXIt, tig. 5.)

3. Section of specimen "apluximating to some varieties of $I$ '. stamtomi," from l'onil canyon, New Mex.; Coll. C.S. Sat. Mus., No. 9735.

t. Sirle view of same specimen. (For suture, see l'l. XXYll, fig. 1.) Iontana croup. C Pluer ('retaceoll. 326 


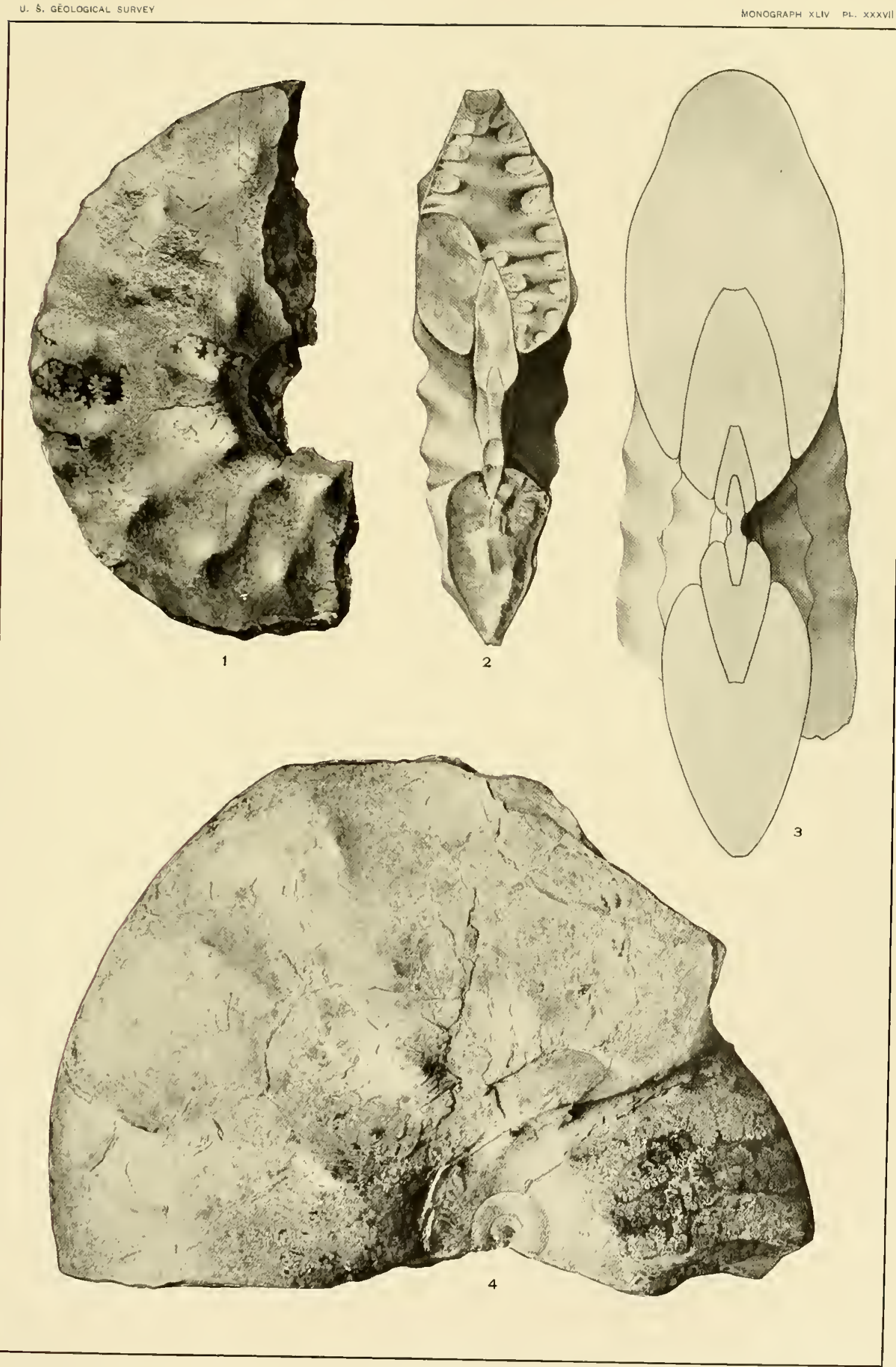



PLATE XXXVII. 


\section{PLATE XXXVIII.}

\section{Pinacenticeras.}

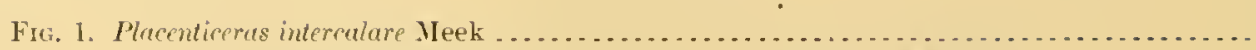

suture of speeimen from near Harper, Wyo. (See Pl. XXXVII.)

IInitana group, [pper Cretaceous.

F1G. 2. Plarenticeres interculure var. costutum Hyatt ..............................

Sille view of type of variety, my collection, purchased from Ward. Probaby from Black Hills, S. Dak.

Iontana group, Tpp.r Cretaceous.

328 


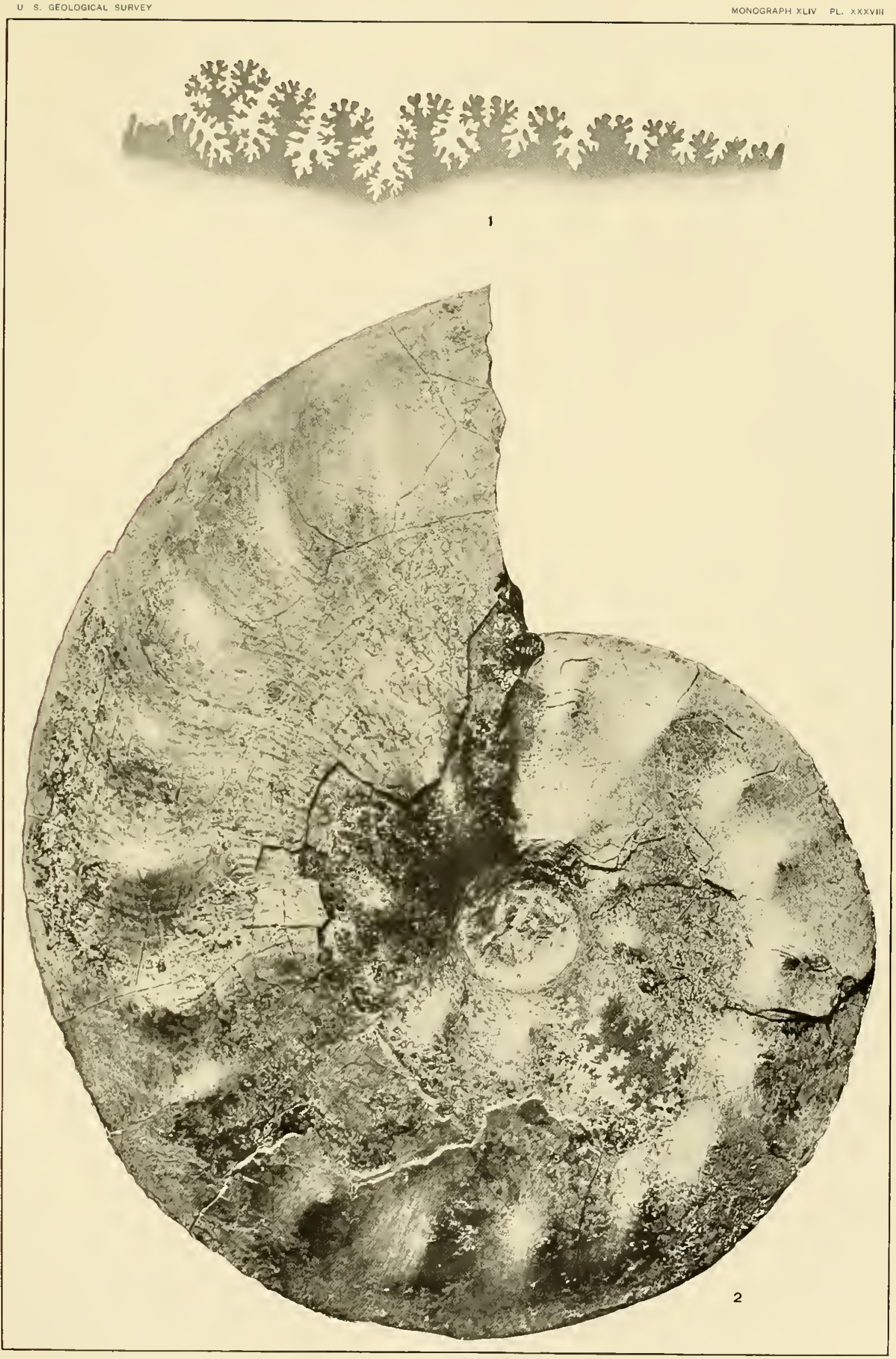

PLACENTICERAS. 

PLATE XXXIX. 


\section{I'LA'TE XXXIX}

\section{Placketicheras.}

linge.

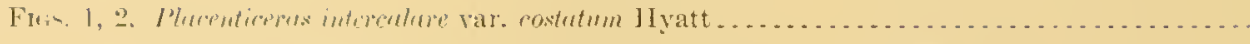

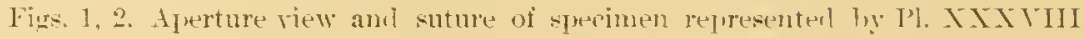
fìg. :-

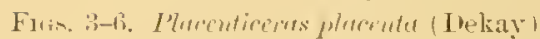

Fig. :- Frament of a small specimen from Chesapeak aml Delaware canal. ('oll. Acart. Nat. Seci. Phila.

4. - nture of same, $\times 2$.

$\therefore$. vile view of small specimen from Lenola, x. J.

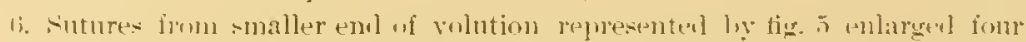
dianeters see Pl. XL, fiers. 1, 2).

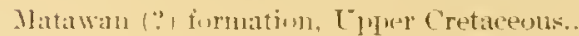

330 


\section{का है}

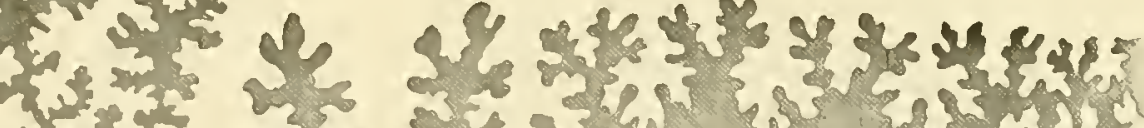

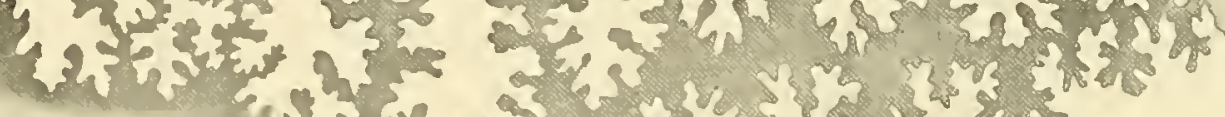

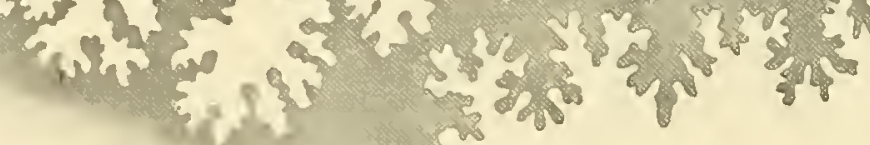
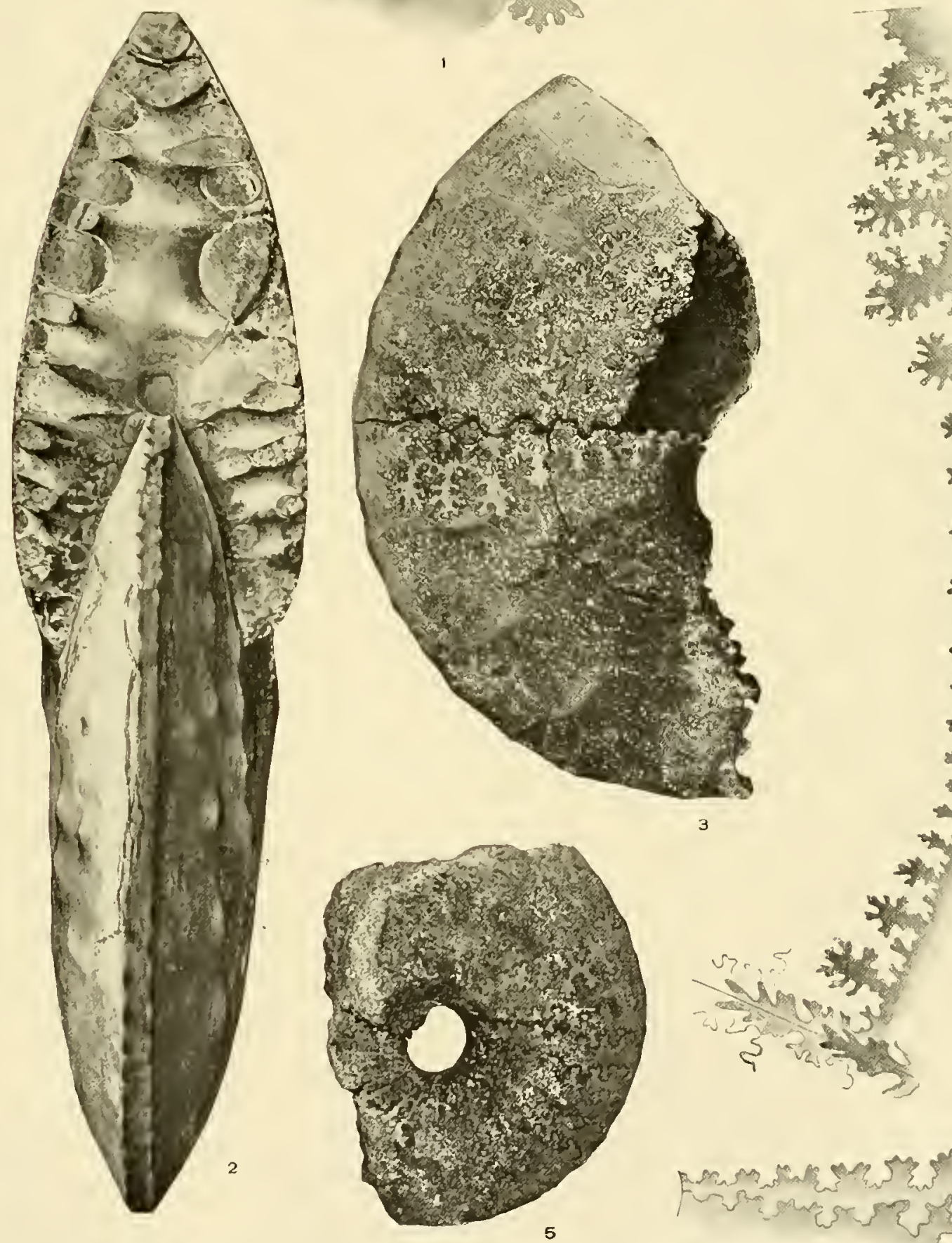
tit करำ. (⿻) तै है H. 2) 3 है।

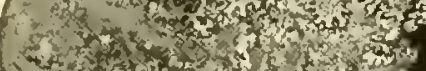

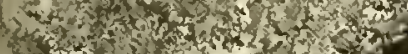
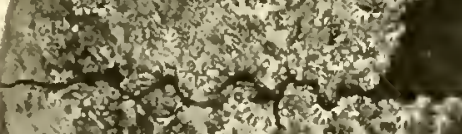

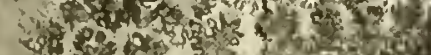

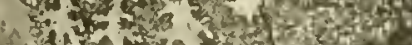

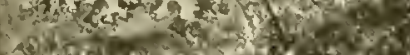

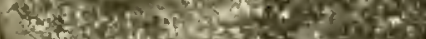

(n)

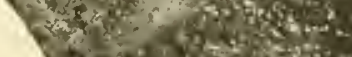

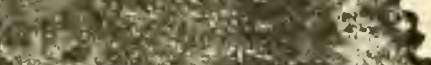

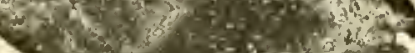

ir

3

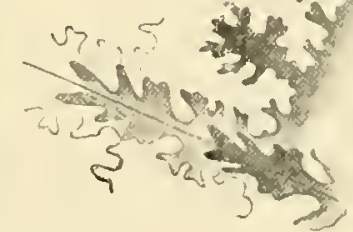

prings ant

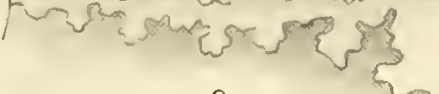



PLATE XL. 


\section{P'LA TE XI.}

\section{Placenticken.}

Ficis. 1, 2. Mturentiremes pluecntu Dekay)

Fig. 1. Peripheral view of specimen represented hy Pl. XXXIX, fig. 5

‥ Side view of same, enlarged nearly two liameter.

Figs. :-7. Pluenticeres sfontomi var. bolli II yatt

Figs. 3,4. Aperture and sicle views of the small specinen from Tarrant County,

Tex., in the IIartin collection, Rutger Female Institute, describerl hy Ifeek as $P$. interculare.

5. Suture of same, $\times 2$.

6. Fragmentary s]erimen from Horton's mill, Fallas Connty, Tex.; Coll. Mus. Comp. Zool., Cambridge.

7 . Lateral and internal suture of same, $\times 2$. (see I'l. XLI.)

Taylor beds (?), Tliner Cretaceons. 


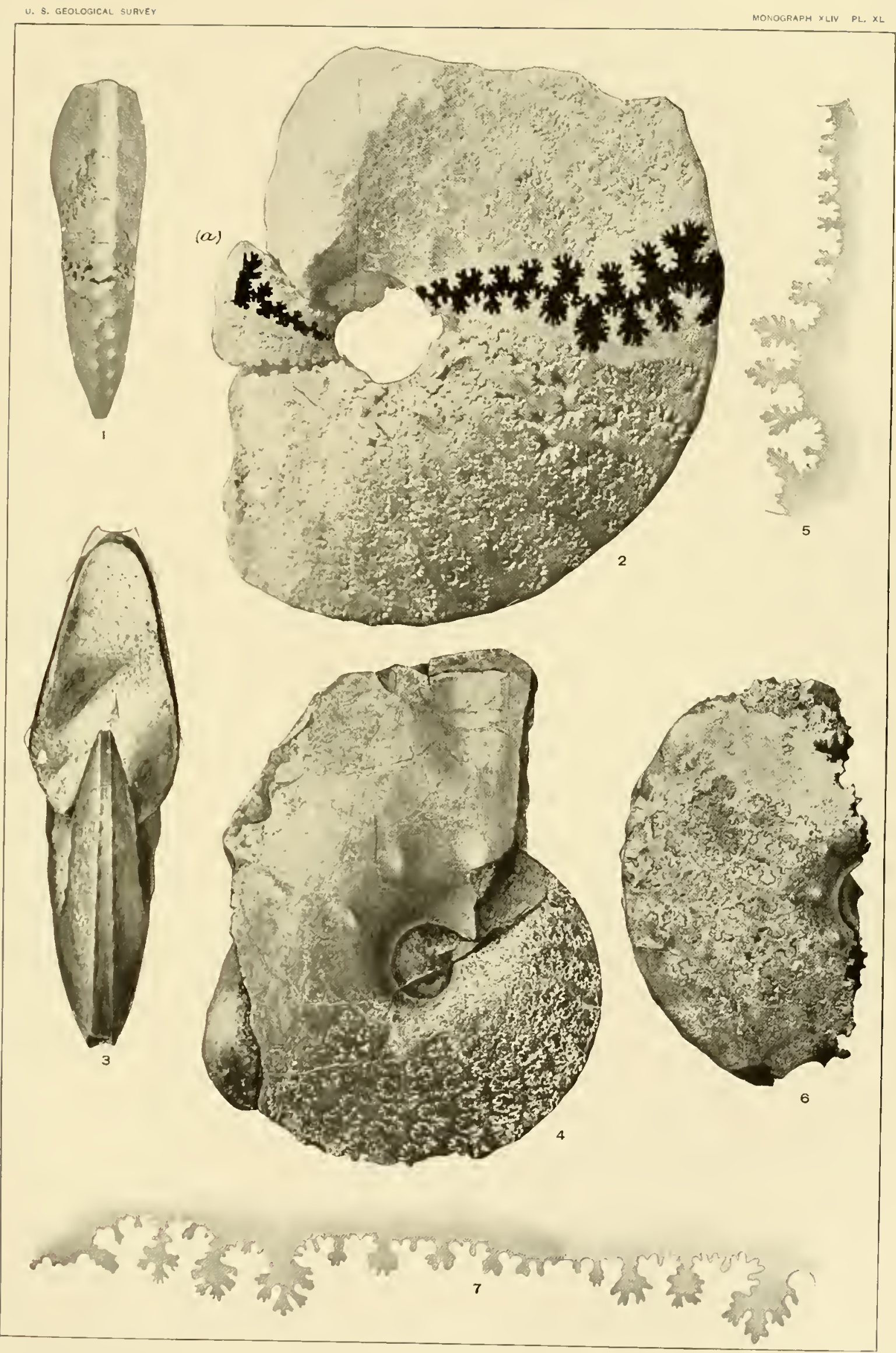



PLATE XLI. 


\section{PLAT F X I I.}

\section{Placenticeras staNtoNi val, botil Hyatt.}

\section{(Page 214.)}

Fui. 1. Fectional view of suedimen represented ly Pl. XL, figs. 6 and 7 .

2. Jesturenl section of same.

$:, 4$. Living "hamber of a larger speciunen.

5. Last suture of same specimen.

6,7. Living thamber of another sjecinten.

Horton's mill, Dallas Cruntr, Tex.; Taylor lest: (?), Tpuer Cretareons; Coll. Mns. Comp. Zowl., Cambrilge. 


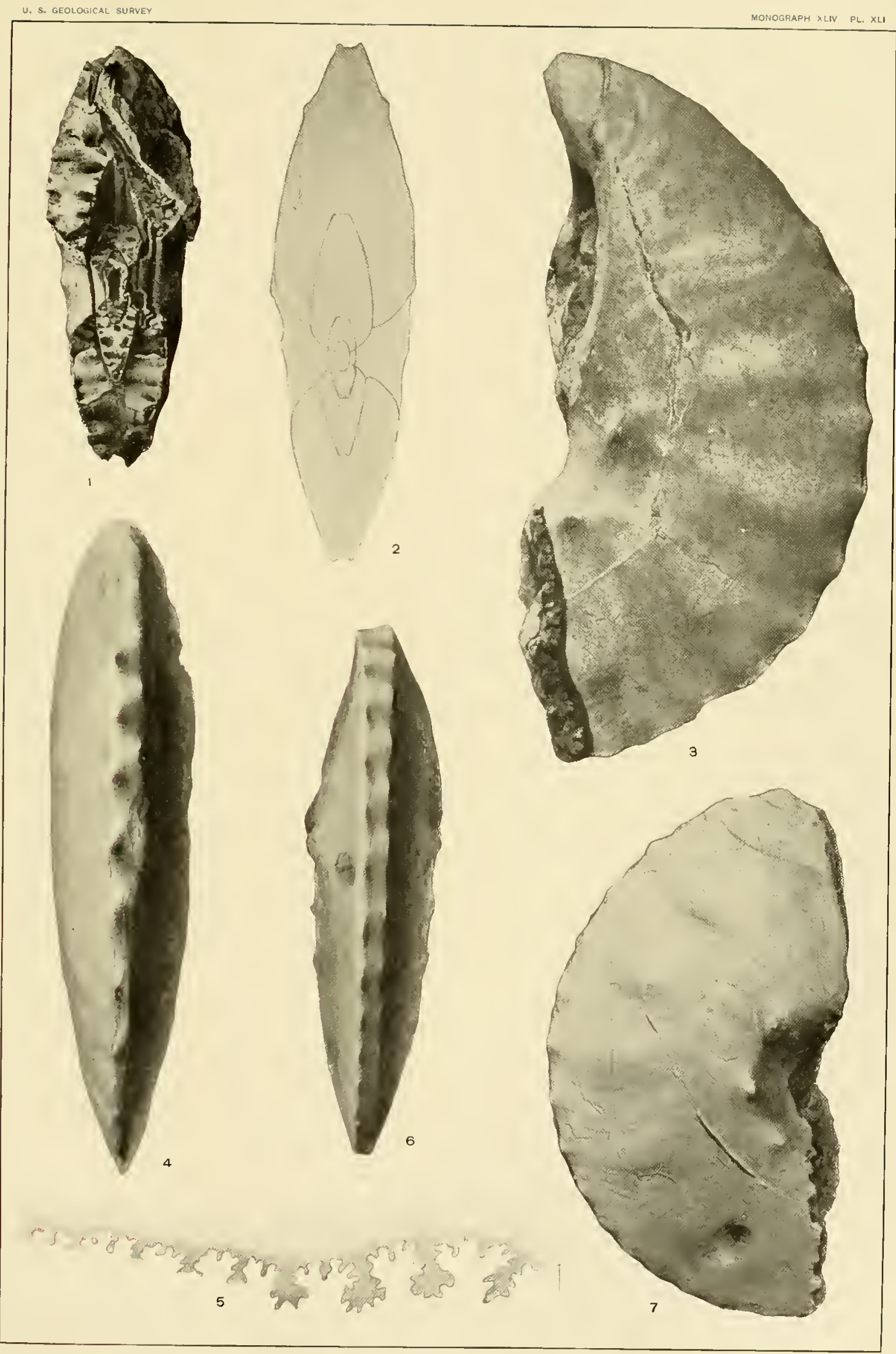

PLACENTICERAS, 

PLATE NLII. 
PLA TE XLII.

P'lacenticeras stantoni var. bolli Hyatt.

(Page 214.)

Fri. 1. Suture of young sperimen enlarget ahut ap dianeters.

2. Part of living chamber and last septa of a large specimen.

Horton's mill, Inallas County, Tex.; Taylor leeds (?), Cpper Cretaceous; Coll. Mus. Comp. Zool., Cambritge.

336 


$$
\text { Hatron }
$$

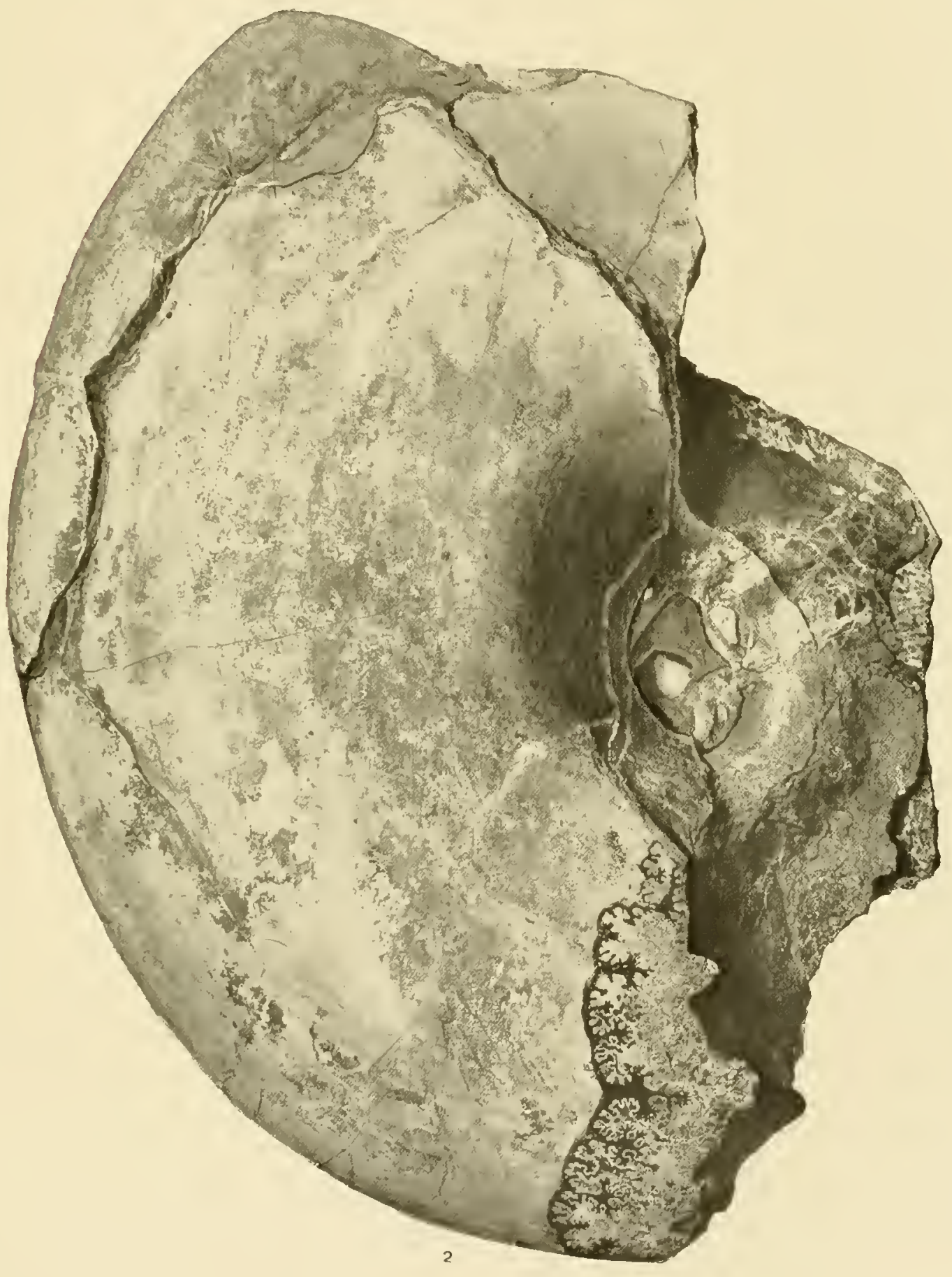





\section{PLATE XJIII.}

MOX XLIF-00:- 


\section{PIATE XLIII.}

\section{Pracenticeras.}

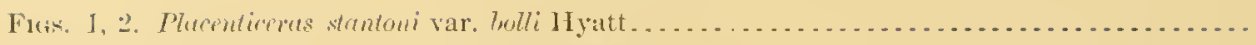

Fin. 1. Fide view of small "wstate speriment.

2 . suture of same, $X 2$.

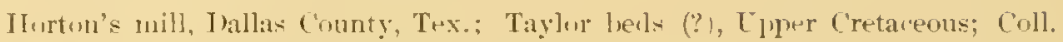
11us. Comp. Zorol., Cambridge.

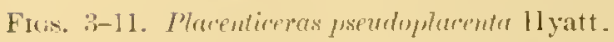

Fig. 3. Sinle view of small fragnestary slecinwn.

4. Sectional view of same.

5. Center of same enlargerl.

(i. Ventral view of first whorls of same specimen much cenlaredel.

7. s. Juner whorls of another speeimen, natural size.

9. 10. Tateral sutures of last whorl of same as indicated on fir. 7.

Upper Kanab Valley, Ltah; Coloralogroup; Clpler Cretaceous; Coll. 1. . S. Xat. Ilu., Xั1. 20:34t.

11. Jarts of internal sutures of epluebic stage when dorsoventral diameter of rolution, measures f!? num.

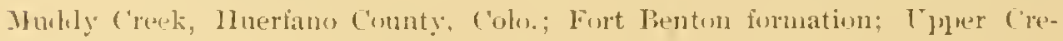

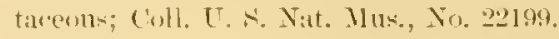




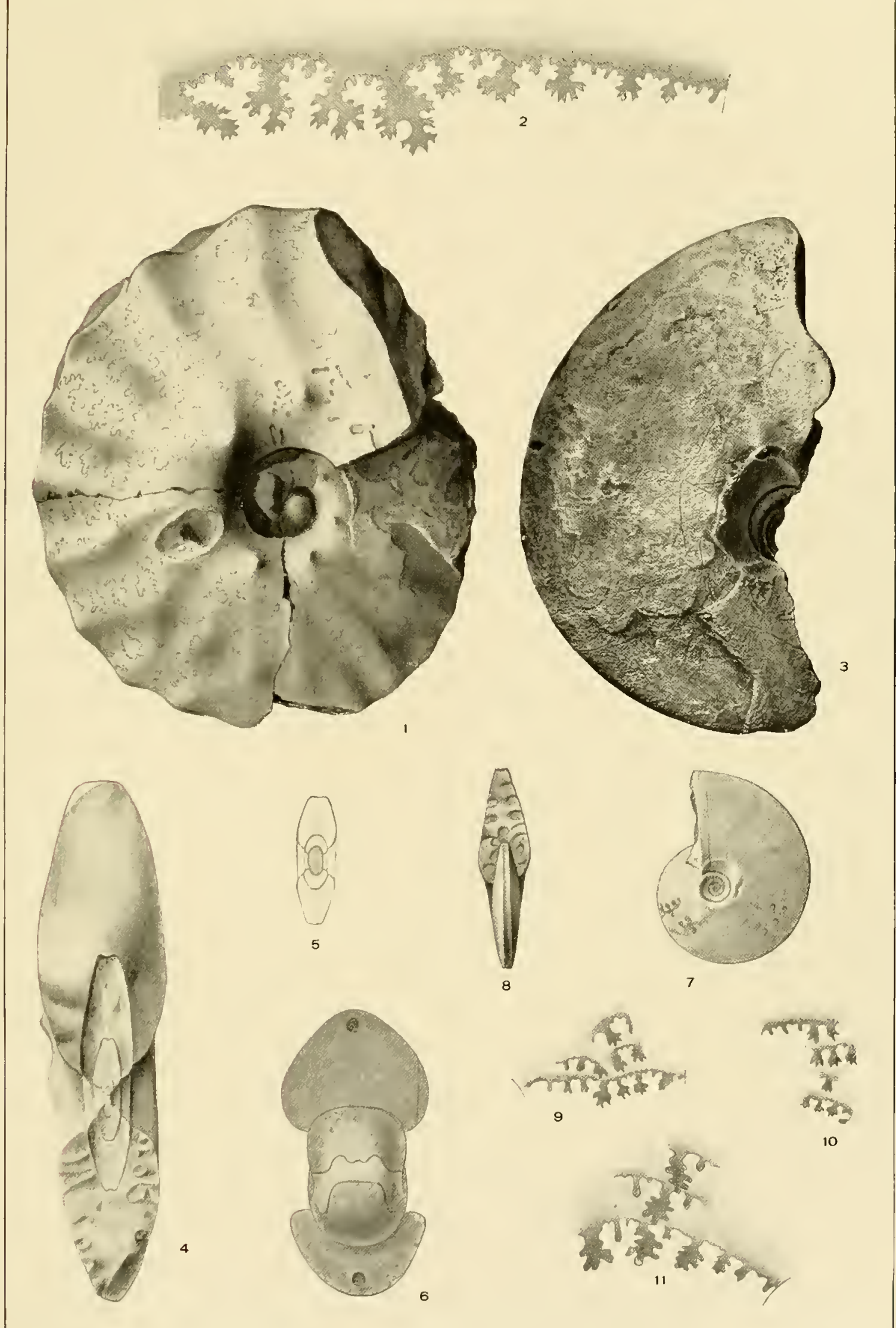





\section{PLATE XIIV.}




\section{I'LAT E XLIT.}

\section{Placexticeras penemoricenta Hyatt.}

(Pacge 216.)

Figs. 1, 2, :3. Three rifw of living chamter of fragmentary sperimen. Barl Lands, near Black Hills; Ther Cretaceous, s. Tak.; my colkertion. 340 


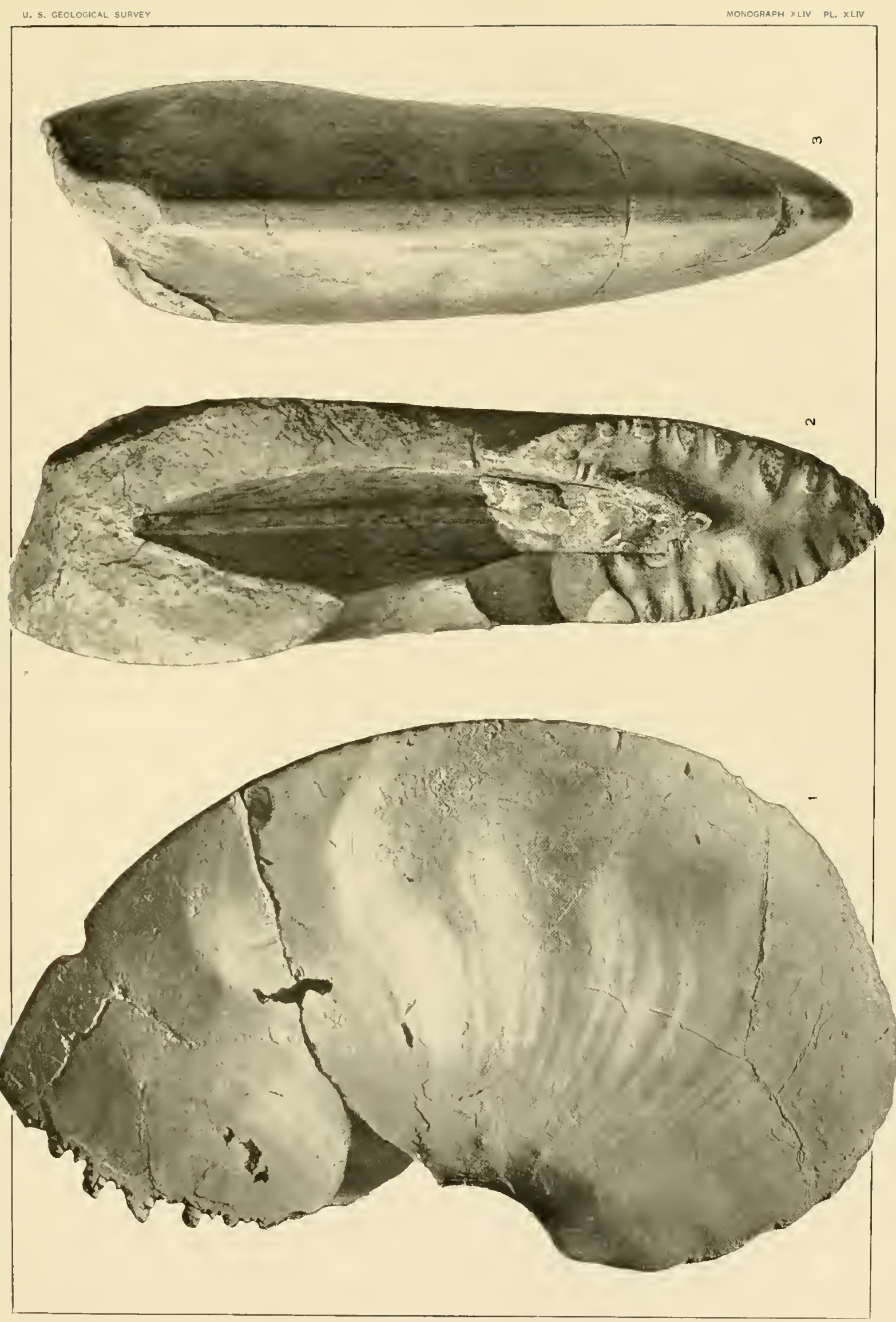

PLACENTICERAS. 



$$
\text { PLATE XLV. }
$$




\section{PI ATH XI.}

\section{P'LACENTICERAS.}

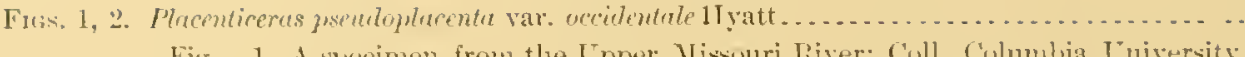

Figr. 1. A suecimen from the Ipper Misiouri River; Coll. Colmmbia Tuiversity, No. $10622 \mathrm{Y}$.

2 . Suture of a young specimen from Iforton's mill, Dallas cinnty, Tex.; 1'oll. Mlus. Comp. Zool., Canbritige.

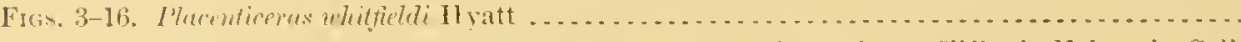

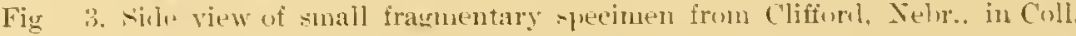
Hus. Compl. Zool., Cambridge, enlargerl.

4. Section of same showing venter of earliast whorls. $x{ }^{3}$.

5. Center uf same, : alkont 63 dianeters.

6. First two sutures and beginning of siphmole of samm - -perimen, much enlarigeril.

7. Beginning of siphuncle of same aitur rotehing with aleid, still further enlargeril.

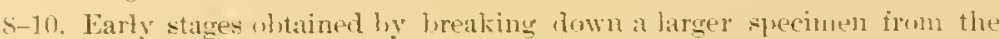
Black Hills, South Dakota, in my collection; enlargenl alwut sdiameters.

11-14. Complete sutures from dorsum to venterwi same stages as firs. s, a, 10. Fir. 11 is ariliest suture visible on thig 9; fig. le is on list ynarter of sane whorl: tier. 1:3 i: lal-t suture on fig. 10, and fier. 14 is nearly a volution earlier.

15. Horal (internal) sutures at diameter of 15 mus.

16. Same at diameter of 40 mm. The last two fignres may not be from same suecimens as fiess. s-14.

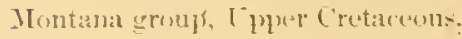




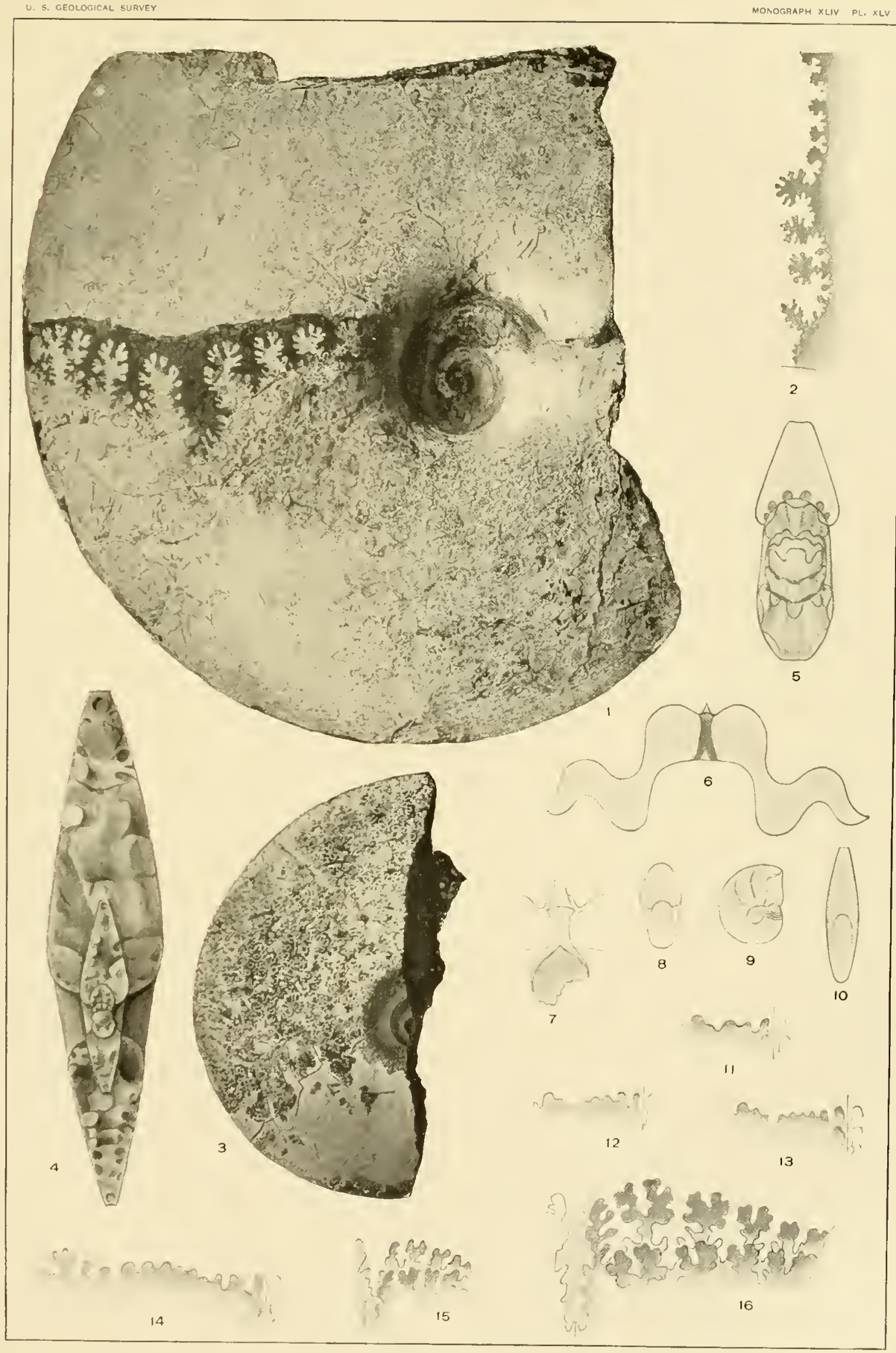

PLACENTICERAS. 

PLATE XLVI. 


\section{PLA T E X L V I}

\section{Placenticeras whitfield Hyatt.}

(Page 221.)

Ficis, 1, 2. Two views of a large specimen, $\frac{9}{13}$ actual dianeter.

Black Hilis, South Dakota; Montana formation, Upper Cretaceous; Coll. Bost. Soc. Nat Hist., No. 11124.

ist 


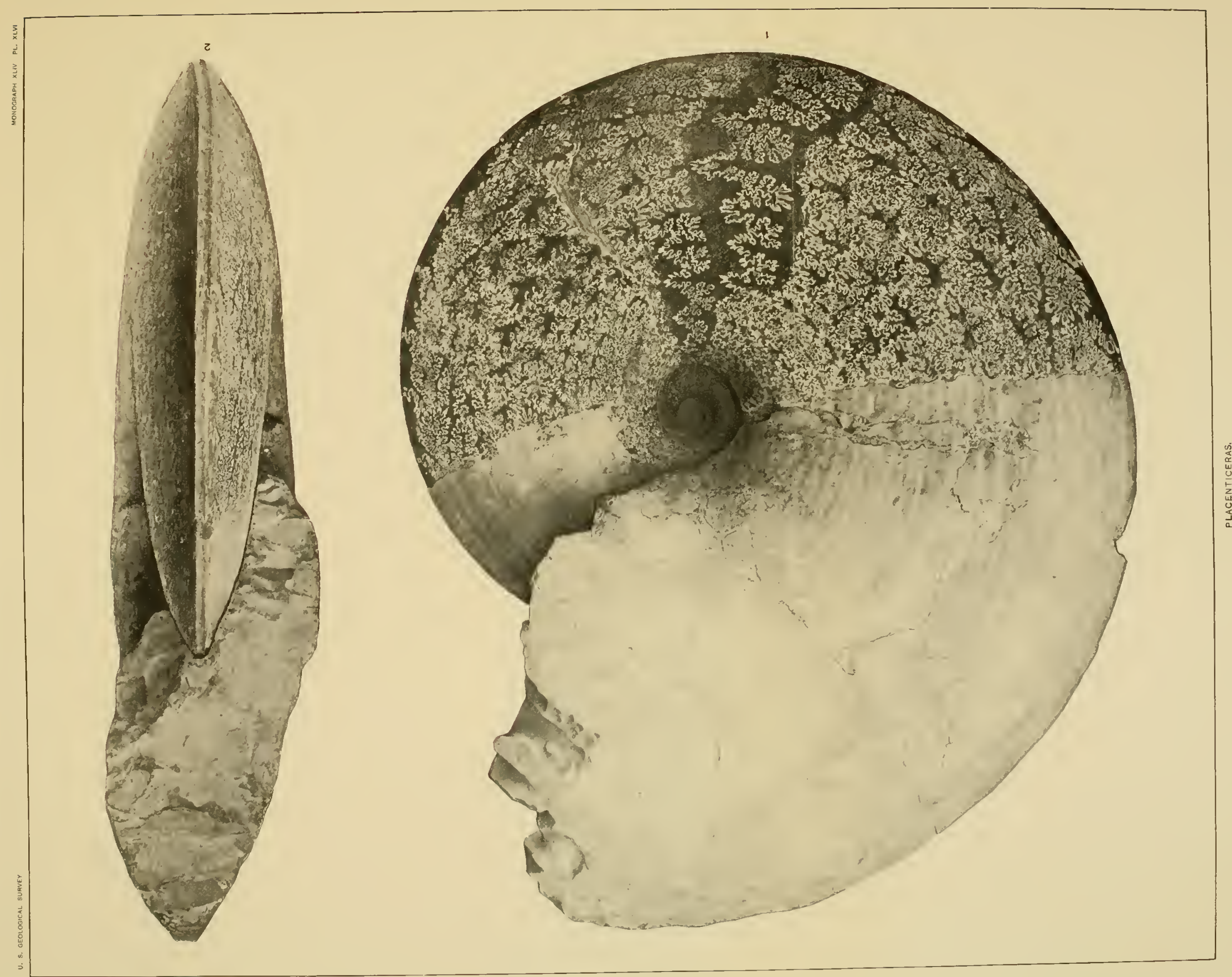



PLATE XLVII. 


\section{F'L TE I I T I 1 .}

\section{Piachentichis.}

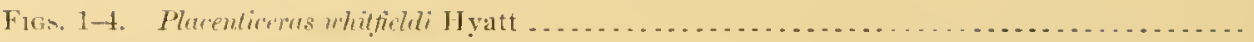

Figs. 1, 2 . Two views of the inner whorls of a small specimen from the lipher Minsouri; Croll. T. E. Nat. II s., No. 1893h.

:3. Fraguent showing peculiar soulpture uf the inner shell layers. jrobahly from Jiack IJills, South Takota; ny collection.

4. Inother sperimen showing sinilar senlpture fron same collestion and regrion.

Juntana group, Upuer C'reticeous.

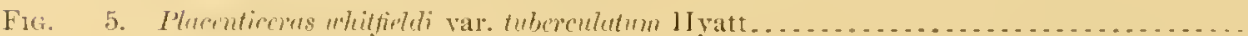

Fig. 5 . Side view of the type of the variety.

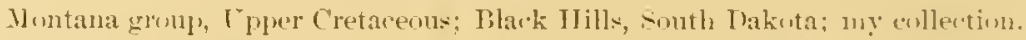

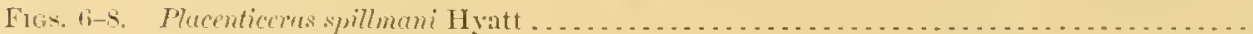

ligs. 6, 7 . Two views of the fragnent on which the species is haserl.

s. Part of weathered suture of same.

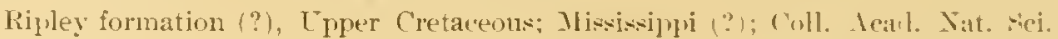
Philit.

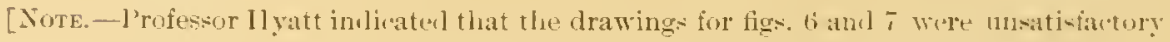
to liu, inat the sperimen is too imperfect to serve as the basis for at restoration]. 


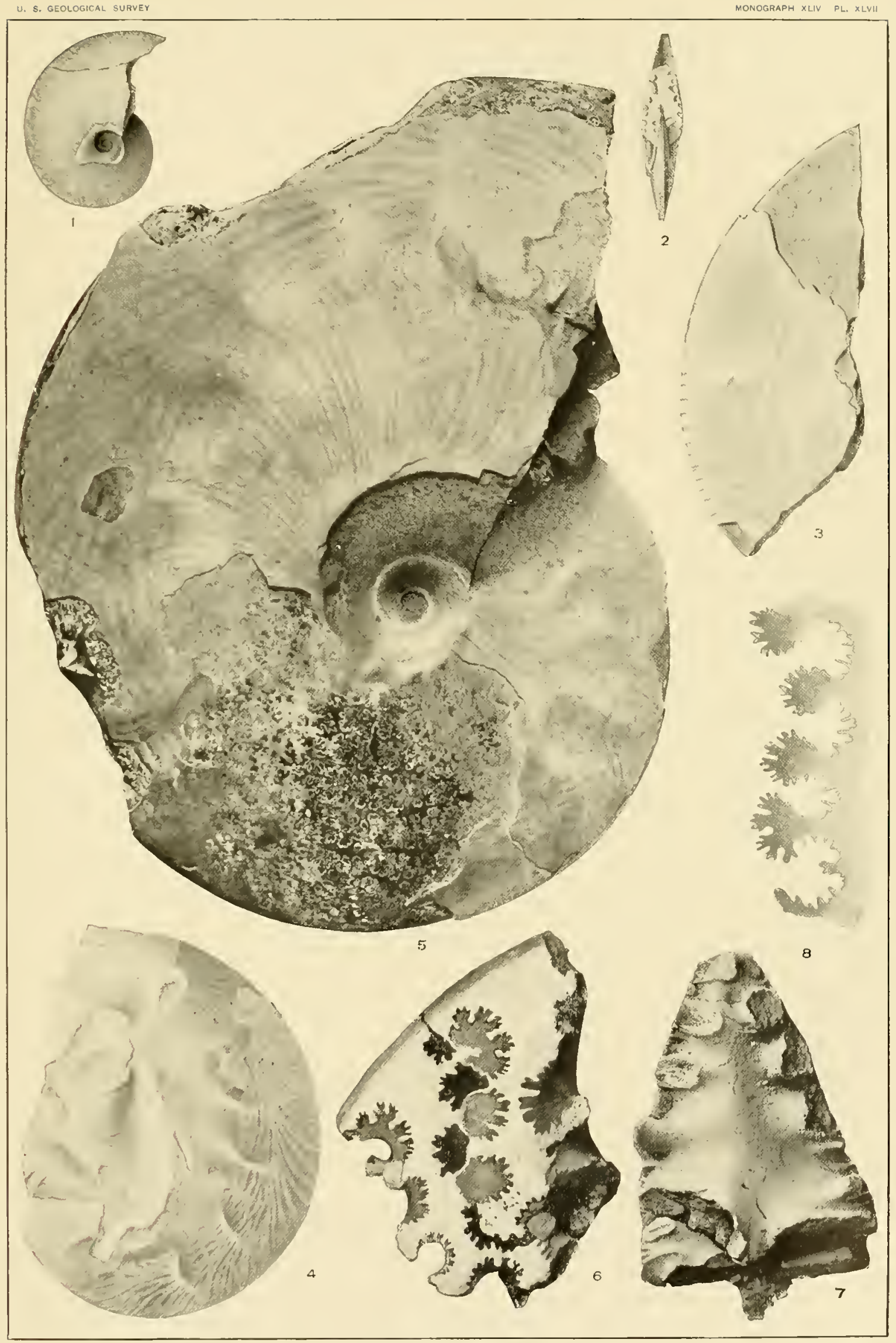





\section{INDEX.}

[Names in italic are synouyms; figures in bluk-fuce type are numbers of pages on which descriptions appenr: figures in italic denote illustrations.]

\begin{tabular}{|c|c|}
\hline & Page. \\
\hline ...................... & Ammonites-Continues. \\
\hline 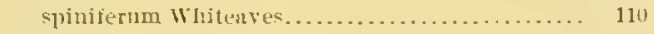 & pitrdenalis von Buch \\
\hline Acceleration of developraent .............. 19-23, 1,9-190 & jaccuta Iekay \\
\hline Acompsocerins Hyatt .................... 10h, nuste; 111-112 & plewiscpla conrad. \\
\hline borliumense (Schlüter) ................ 111-1 I" & 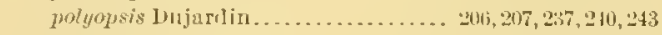 \\
\hline 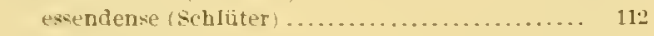 & movincialis dorbigny ......................... 131 \\
\hline renevieri (sharpe)........................ I1: & julchelus d'orbigny ................. 14s, 140,141 \\
\hline Aconecerus Hyatt .................... \&. : 191,101 , note & renerirrisharpe........................... 112 \\
\hline 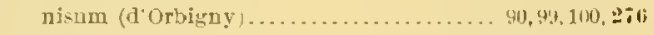 & requienianus d'orbigny ........... \\
\hline Agassiceras... & rohini Thiollitere $\ldots \ldots \ldots \ldots \ldots \ldots \ldots \ldots \ldots \ldots$ th \\
\hline striarieq..................................... & 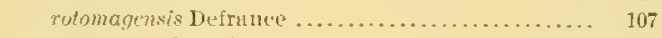 \\
\hline Amnllheus chrayi de Loriol. .......................... & roycrianes d orbigny....................... 1lit, notes \\
\hline 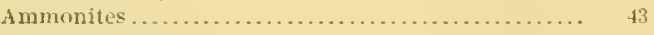 & mustims ............................. note \\
\hline 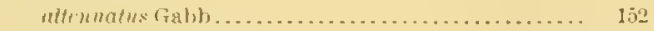 & silu Furloes. \\
\hline 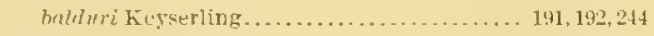 & smallovi shumari .............................. \\
\hline brlvirlermsi* Cragin ..................... 15s & syriarts von Buch . ..................... 32,14ti-150 \\
\hline billwhtutus Roemer . . . . . . . . . . . . . . . . $213,2+4$ & syntulis Morton...................... $205,207,237$ \\
\hline bilubutus Gabb............................. 30 & surlul is var onbign!umus sichliter. . . . . . . 235, 241,242 \\
\hline 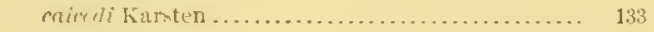 & smotalis var. pollypsis schluter. . . . . . . . . . . . . 239 \\
\hline redillus d'orbigny.............. & 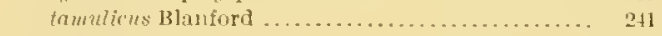 \\
\hline clypriformis dorbigny........................... & 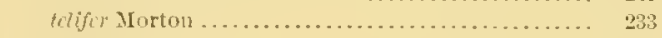 \\
\hline compressissimus d'orbigny..................... & 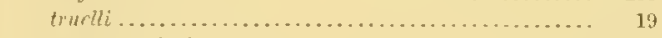 \\
\hline rka $\ldots \ldots \ldots \ldots \ldots \ldots \ldots \ldots \ldots$ & whus Stoliczka .......... \\
\hline rbigny................................ & vibramenusus d'orbigny ................ 119,17૫,240 \\
\hline crnssiterta stoliczka........................ & riminulis stoliczkat....................... 115 \\
\hline rnuliffi stoliczka ............................ & vielbunci dorbiguy .............................. \\
\hline 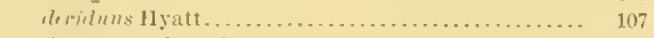 & 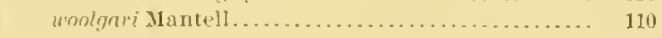 \\
\hline 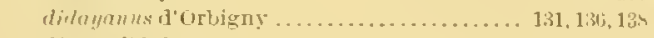 & 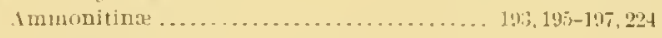 \\
\hline dispur d'orbigny ........................... 111 & 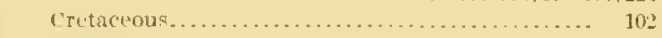 \\
\hline ble anil roquaml. ................ & disappearance of tharacters ..................... \\
\hline 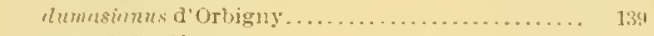 & of the Jura, relation to those of the (setacenus. . . 19-20 \\
\hline 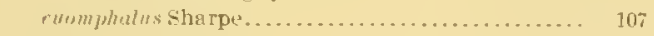 & 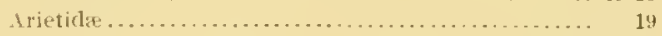 \\
\hline 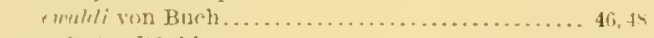 & Irrestation of rivelopment . . . . . . . . . . . . . . . $20-23$ \\
\hline gmbertus dorbigny..................... 135, 1315, 142 & Inyidoceras........................... 14, 106.116 \\
\hline yrilinms d'orligny..................... 44,90 & 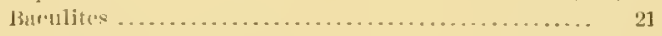 \\
\hline gundulnpse Roemer ...................... 197,211 & Butmisiceras Grousonvre..............26, 27, 111,112 \\
\hline Iroplowphylln Redtenbacher ..................... & desnmulinsi frousouve . .......................... \\
\hline harttic (Hyatt) ................................ & baherfellneri Grnssontive ....................... \\
\hline \& (Neumayr ant Uhligr).............. & 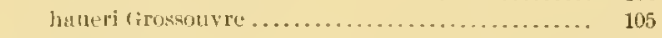 \\
\hline Intirluvius Sharpe ............................ & Batbmoreras .......................... lis, note \\
\hline Imntisuluris Owenl. ........................ $71-75$ & Buchiceras 4 yatt . . . . . 25, 26, $27, n 1, \times 4,112,144,145,191-193$ \\
\hline limligi harsten ........................ 134 & rulenuutum 11 yntt . ...................... 33,151 \\
\hline Lubutu Tisomey ............................ 66 & belviderense Cragin ....................... 15, \\
\hline manmillaris........................... 10s-110 & hilobatum ................ 25, $2-89,30,31,191,054$ \\
\hline mammillulus ........................... Iov & imaldi (von Buch) .................. 40,44,4i, 51 \\
\hline mant lli sowerby...................... 114, 115, 141 & foumrli Bayle................. \\
\hline murcousituus d'orbigny ......... & harttii (Hyatt) .......................... 103 \\
\hline 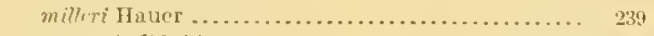 & serrutum Hyatt.............................. . . . . . . \\
\hline 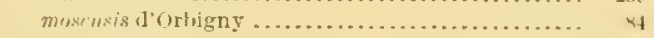 & slizcuiczi Fallot ........................... \\
\hline 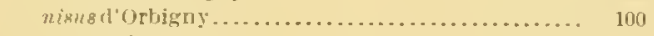 & smullusi (Shumard) .......................... \\
\hline noultrsuides sichliter........................ 111 & 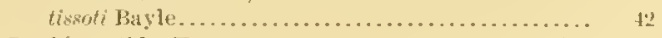 \\
\hline orhimmynnus Greinitz ..................... 235, 240 & Buchiceratidx Hyatt................ \\
\hline pethernalis Roemer ................. 59, 154, 40, 153, 165 & Calycoceras navicularin ........ \\
\hline
\end{tabular}




\begin{tabular}{|c|c|}
\hline \begin{tabular}{c}
\multicolumn{2}{c}{ Prge. } \\
$\ldots \ldots \ldots \ldots \ldots$
\end{tabular} & $\begin{array}{r}\text { 1'aga } \\
-129,130,134,13 ;-136\end{array}$ \\
\hline ... 129, 130, 1333-131 & gulcatoide- Karst \\
\hline enicedi ( Karsten). & guleatus (Karsten) \\
\hline guleatu (d'orhigny). & releziensin 11 yat. \\
\hline lindigi เ Kursten). & rilutuceras nettrmuntum UI \\
\hline subcaicedi (Karsten) & Goniatitin't... \\
\hline ........... 117, 1:31, 135,136 & T. 122, 12\%-130, 133, 13\%-137 \\
\hline Cerrtiks harthi Hyutt.. & eorioli Niekles. \\
\hline eratitine...... & heinzi Coyuand. \\
\hline - 101, note; 117,129 & hispraniea fl yatt \\
\hline note; 116 & $116,122,1: \%, 132-13: 3,29: 2$ \\
\hline hoffaticeras flyatt.... & orachensis (Coquand \\
\hline barjonai (Cboftat). & macheneis sayn...... \\
\hline (donvillei (Peron)... & 31-13:2, 133-136, 242,284 \\
\hline meslei ( Yeron ........ & pulchelliformis Hyat \\
\hline Classification, tabular statement of ................. $15-18$ & kayni 11 yatt ........... \\
\hline$\times 3,85,47-49,91,100,101$, note & Heinzidet .......... \\
\hline .. $41-31,95,2 \pi 2,2 \pi 4$ & IIemitissotia Peron. \\
\hline$\ldots \ldots \ldots \ldots \ldots \ldots \ldots, 100,276$ & \\
\hline …... 91-93,94-96,97,2\%? & eron. \\
\hline - & eeadouroensis Choffi \\
\hline ............ $16-99,276$ & djelfensis (Peron). \\
\hline .. 24, $,-100: 101$, note & morreni (Cornand). \\
\hline $\begin{array}{r}\text { ore, Edward I., on accele } \\
\text { development .. }\end{array}$ & $\begin{array}{ll}41 \\
\ldots \ldots \ldots \ldots \ldots\end{array}$ \\
\hline oronites ... & Heterotissotia Peron..... \\
\hline 130, note & \\
\hline .. 101-105 & $101 ; 130$, note; 193 \\
\hline Cretacic, use of term & .. 131, note \\
\hline ... 101, note & ...... 192, 193 \\
\hline$\ldots \ldots \ldots \ldots \ldots \ldots .25$ & $105 ; 131$, note; 137,192 \\
\hline arrestation of. $19-23,189-190$ & Horizons, table of..... \\
\hline 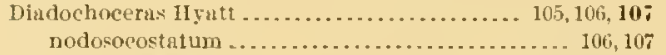 & 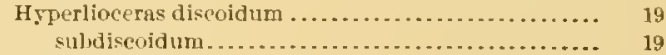 \\
\hline 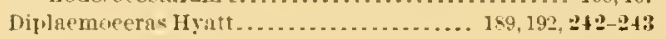 & 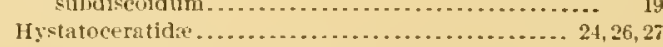 \\
\hline ................. 943 & Indoe \\
\hline$-2+3-241$ & 3 \\
\hline .. 105-107, 108-109, 113 & lense Noetling. \\
\hline ... 109, 113 & Knemieeras \\
\hline .... 1110 & .. $33,131,152,296$ \\
\hline ..... 110 & . $149-1501,152,246$ \\
\hline Echinoids, parallelism in loen derelopment of ....... 195 & eоmpressum Hгaitt... \\
\hline ..... 20,21,5\&, & ......... 152, 295 \\
\hline $82,196,198,242$ & $14(i-144), 150,256$ \\
\hline 159,258 & ....... 15: 150 \\
\hline$-1: 5,300$ & $\ldots 144-152$ \\
\hline $159,160,173$ & $\ldots+\ldots \ldots, 103$ \\
\hline …....... 153 & andii............... \\
\hline$\ldots \ldots \ldots \ldots 1 ; 1-175,296,296$ & \\
\hline$\ldots \ldots \ldots . . .1 \times 3$ & Let \\
\hline …..... 115 & $56,5 \%$ \\
\hline ;, $167,170,175,29 ?$ & Zittel). \\
\hline ........ 16i-16i, $29 g_{4}$ & ........ $41,13 \bar{i}, 144$ \\
\hline note: $29 n$ & \\
\hline (2... & Mammitidn .......................... 24, 27; 101, note: 109 \\
\hline ... 16:2-161, 16i, 171, 240, 28:2 & 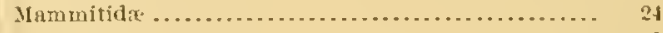 \\
\hline . & ... 110, 111, 118 \\
\hline $54,161,16+16$ & \\
\hline & (Bayle and Coquand). \\
\hline 193,243 & ......... 113 \\
\hline 102 & $\ldots 111,113,114$ \\
\hline $83-85,100$ & picteti Inģatt \\
\hline & \\
\hline$\ldots 24,83-n ;$ & vicinnle (Stoliczka) $\ldots \ldots \ldots \ldots \ldots \ldots \ldots \ldots \ldots \ldots, \quad 115$ \\
\hline assified list of. & utelliceratida .......... \\
\hline .... 102 & 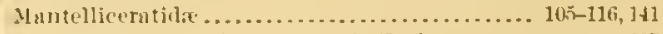 \\
\hline & Ifetacanthoplite's rhotomagensis (befrance)........... \\
\hline
\end{tabular}


Page.

Metasigaloceras Hyatt ............... 106 rusticum (sowerby) ........................ 10.

Metatissotia Hyatt ...................... 43, 45, 50,5.5 auressensis (Peron) ..................... ewalli (von Buch) ....................... \$4, 5 2 fourneli (Bayle) .......................

haplophylla (Redtenbacber) ................. th

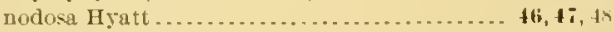
rohini (Thiollière) ..................45,4ti-1;, th slizewiezi (Fgllot) ..............

Metengonoceras Hratt.......... 153-155, 154, 170, 179-141 ac'ntum Hyatt ................... 14t-1 -5, 157, 304,306 ambiguum Hyatt dumbli (Cragin

1.3-1 int 304 $180,1 \times i-1 \times i, 306$

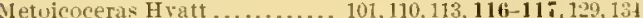
acceleratum Hrat $120-1 \pm 4,250$ gihbosum Hyatt.

kanabense Hyatt $1 \geq 1-1: 2,283$ $11,-1 \pm 1,122,123,131,274,27,39$ ? whitei Hyatt ... 11, $101,1,0,107,124,2 \pi 4,2 \times 0$ Metwicoreratida......................... 11;-12s

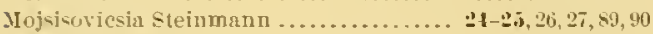
Aurfeldi steinmann ......

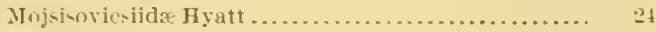

Nerlol,ites Fischer.................. 54, 101, 141, 15s, 17 choHati Hratt ......................... 17., 3n? cothut Jickles............................. 111 peroni Hyatt . . . . . . . . . . . . . . . . . . . . vibrayeanms (d'Orbigny゙) . . . . . . . . . . . . . . 175.179

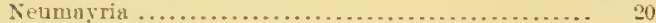
arpidoides .................................. 19

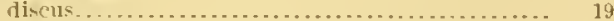

hor hstetteri ................................ 19 serrodens ............................. 19

Nickle-ia Hratt ...................... 13t, 137, 13৮, 110 alicantensis Hyatt....................... 13: bertrandi (Niekles) - ...................... 138 didayalla (d'Orbigny) ...................... 131, 134 dumasiana (d'Orbigny)................ 13, 139, 2ho karstenj (thlig) .......................... 134 lnpurenti (Nickles)....................... 138

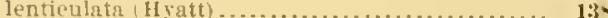
levyi (Nicklis)........................... 134 malladic (Nicklès)........................ 134 moltoi (Nickles) 1triani (Nicklè-) .......................... 13m pulchella (dorbigny) ...................... 141 zeilleri \{Nicklès\} .......................... 13 b

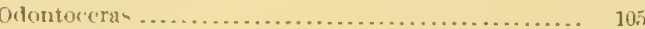

Olcosteplanus............................. 102

Orthuceratites .................................

1) вynuticeras............................... 10 .

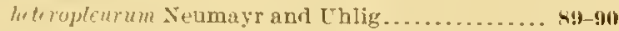

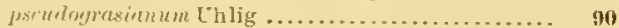

l'achycampyli ..............................

Pachydjscons ............................... 90,102 Paralenticeras Hyatt . ....................... st, note; sieversi Gerharlt......................

Paratisotia Hyatt...................... $11,45,50,55,113$

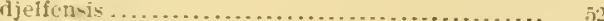
ficbeuri i Grussonrre) .................. $40,50, \mathbf{i 1}, 52$ tourtueli Grossouvre ...................... 52

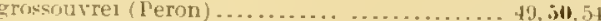
regula ri. Hyatt ....................... 50, .83 - it . 258

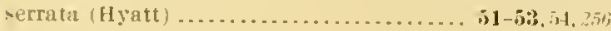
thomasi (Peron).
Pedioceras Gerhardt 105, III) caquesensis .............................. 107 cundinamarca Gerharit ...................... 107

ubaquensis ... ............................. 10 t

Pedinceratide.............................. 105

Peroniceratida . . . . . . . . . . . . . . . . . . . . . . . 24, 27

Phricodoceras . ................................. 105

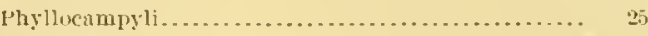

I'hylloceras............................. $76,4 \times, 231$

Phylloceratida. .......... 100; 101, note

l'lacenticeras lieek ............................ 20 $22,94,140,145,153,155,179,1 \times 5,1 \times 4-196,243,244$

ealifornieum - 140 note crussatum 11 gatt............................. 211

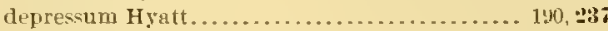
ebrayi (de Loriol) . ...........................83 t-2:3

fnllax Castillo and Agıilera ................. fritschi Growsouvre ....................... 240

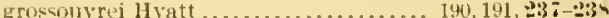
gutulahup (Rotmer) ................ 188-191, 194i. 157-194, 200, 202-204: 206, note: $211,213,237,310$ mcisum $\mathrm{H}$ vatt :3:34 interealare Meek............................. 190 $196,205,246,-117-211,214-216,221,322-336$ qentimulare Meek liardens, Whituaves......................... 127, 124 memoria-sehloenbachi Laule ancl Brualer........ milleri (Haner) . .................. 190, 191, 23a,

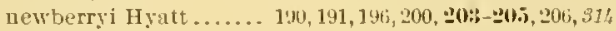
orbignyanum (Geinitz) ... . . . . . . . . . . . . . . . t11 macificum.

placenta (Dekay)............ 190, 191, note: 196, 202, 209. $210,211-211,215-219,221-23.23,225,233,236,380,339$

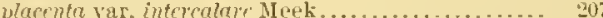
Ilanum Ityatt. . . . 1 190, 191, 196, 20:2-203, 204,211,315, 320

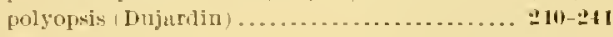
meuroplacenta Hyatt ............. 1,40,190,

$196,214, * 11 i-417,232,338,840$

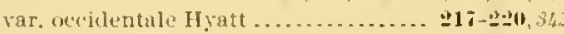
useudorbiouvan requietrianum d'orloigny" ..................... 236 ranearlosenke Hyatt .... 191, 196, 200, 202, 2ut; $211,512,514$

var. psendosirtale 11 vatt . .

$191,197,199,2011)-20+2,316,319$ whfitteri Hyatt .................... 236, $2339,241,242$ sillmaui Hyatt ....................... $\$ 46$ stantoni Hyatt ......... 199, 190, 196, 214, 217, 215, 233, $230^{\circ}$ var, bolli Hyatt .......................... 207 , $212,211-116,219,225,244,383-33$.

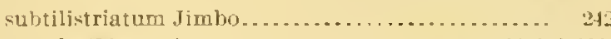
syrtale (Mortnn) ...................... 29.2, 149-191

$196,198,200,201,203,204,20.5-201 \mathbf{i}, 204-213$, $215,217,200,221,232,233,236-239,242,306,309$ var, halei Hyatt . . . . . . . . . . . . . . . . 20.5, syntule var, quadratum Grossouvre ............... 937 tamulicum (Blanford) ............... 236, 211-21: telifer (Mortion) . . . . . . . . . . . . . . . . . . uhligi flofiat ....................... 152, 199,235

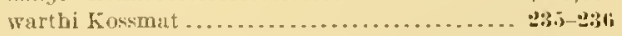
whitfielli Hyutt .................... 22, 189, 190.

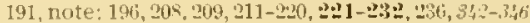

var. tuberculatum Hyatt....... 209, 2211, 220, 221, ㅃ:3:2

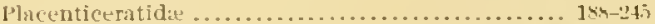
Platylenticeras Hyatt.............. 81 , note; $85,44-489,24.5$ gevrilianum (d'orbiguy) ................... 44, heterop]enrum (Neumayr and L"hlig) .... \$! $\$$-91, 99, 214 psendogracianum (Ch]ig) .................. sy, 90 


\begin{tabular}{|c|c|}
\hline $\begin{array}{l}\text { Page, } \\
.34,+1\end{array}$ & Rnemeroceras Hyatt-Continued. \\
\hline michuleti 1 ' & gubhi Hyutt................ \\
\hline lyplectus cupellinus.... & subilaumm liyatt... \\
\hline diseroirles. . ......... & syriaciforme Hyatt ........... \\
\hline Primordialidac...... & 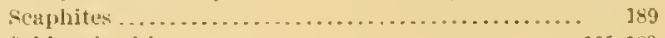 \\
\hline Prionotropiulat . . . . . . . . . & 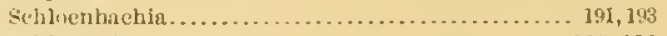 \\
\hline 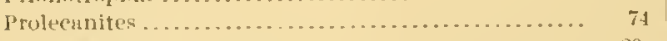 & s.hlutericeras Hyatt . ................... 110-111 \\
\hline Protengonoetras Hyatt . ...................... 20, & luubei Hyatt............................... 111 \\
\hline $153,15 \bar{t}_{2} 134,179,181,1 \times 6,164,189,192,194,204$ & michelobenke................................ 111 \\
\hline emarginatum (Cragin) .................. 154, 157, 176 & nodosoides (sehliiter) . . ................... 110,111 \\
\hline 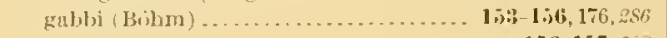 & vitbanci (dorbigny) ...................... 110 \\
\hline 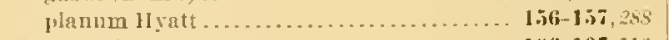 & Sharpeicera4 Hyatt .......................... 111 \\
\hline fulaspiroceras Hyatt .................... 106-108. 116 & inconstins (Schlüter) $\ldots \ldots \ldots \ldots \ldots \ldots \ldots \ldots . . . . . . .111,112$ \\
\hline um (Stoliezka) . .................. Jut & laticlavium (sharre) ....................... 111,113 \\
\hline itesta (Stoliczka) .......................... & selulueteri Hyatt............................. 111 \\
\hline cunliffi (Stoliczka) ........................ & siguloceras tay]ori............................ \\
\hline im Hyatt............ & splecies, rlassified list of . ...................... 15-1 \\
\hline 107 & Specific differences, shsence of, in Placenticeras..... 196 \\
\hline footeausum (Stoliczkn).................... 106, jog & sphenodiscide $\ldots \ldots \ldots \ldots \ldots \ldots \ldots \ldots \ldots \ldots \ldots . .24,5 i-83$ \\
\hline sceblijteri Hyatt ........................... $10 \bar{t}$ & SJhenodiscus deek........................... 39, \\
\hline atulue ratites, definition of ......................... & $54-5 \overline{5}, \mathrm{i} \uparrow, 43,47,91-93,149,153,160,141), 195,233$ \\
\hline Hyllites Kosmat...................... 25 & rentodoreatns Noutling........................... \\
\hline issotia Peron ................... 34, 35-86,37,35 & 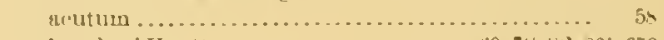 \\
\hline Choffut ............................ 37 & 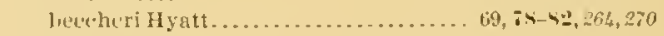 \\
\hline Peron.................................. & belviderensis var. serpentinus Cragin ............ 162.164 \\
\hline galliennei (d'Orbigny) .................. 35, 36,37, 42 & betriderensis var. vdrlcni Cragin................. 159 \\
\hline 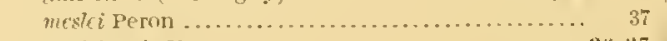 & binckhorsti Bribm ...................... \\
\hline$\ldots \ldots \ldots \ldots \ldots \ldots \ldots \ldots \ldots+3 ; 1 ;$ & 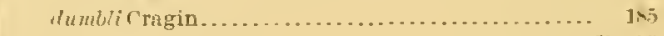 \\
\hline ssotidie Hyatt ........................ 24, 3t-3.i & cmarginutus rragin ....................... \\
\hline 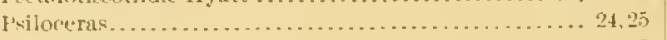 & ulis Zittel ................................ $5 s$ \\
\hline tidida .................................. & boniucki Hyutt................. \\
\hline hellia ....................... $136,137,142,148$ & lentienlaris (Gwen) ........................ 57 , \\
\hline 11 yatt................... 41, 137, 140,141, 14:3 & $54,66,70,71-7,5,7 i-42,94,95,264,270$ \\
\hline (klès) ............. & var, magniticus.......................... \\
\hline$($ Nickliss) .......................... 143 & 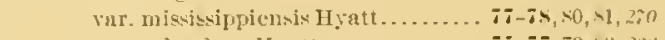 \\
\hline hutugi (Xicklèn........................... 143, 144 & Far. aplendens Hyatt $\ldots \ldots \ldots \ldots \ldots .75-7.79,40,26 s$ \\
\hline ariolat (Nickles) ............................. 143 & lobatus (Tuoucy) ... 65, 64t-71). $71,75,76,50,52,25 \%, 266,220$ \\
\hline 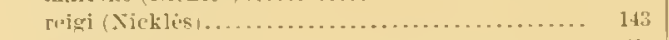 & 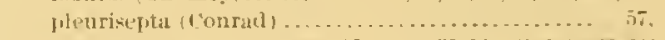 \\
\hline Pulvh+1lin Ehlig.............................. & 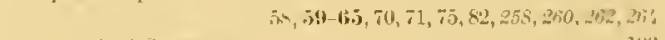 \\
\hline ลง), $112,117,129,131,136,137,139,110-142,141$ & Gromantre...................... \\
\hline meirerli (Karsten ............................. 130,135 & roemeri Cragin .................. \\
\hline 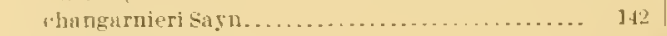 & rututi Gromonvre.......... \\
\hline 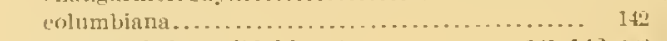 & siva $($ Forbes) $\ldots \ldots \ldots \ldots \ldots \ldots \ldots \ldots \ldots \ldots \ldots \ldots \ldots$ \\
\hline 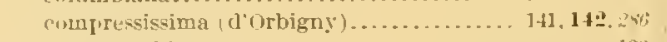 & 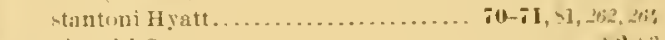 \\
\hline lic ............................. 130 & ubagshi Grossnuvre ..................... \\
\hline 143 & stepheveras................. \\
\hline 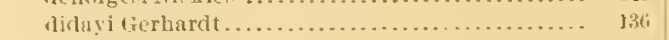 & 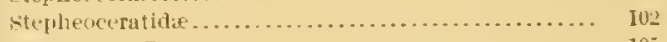 \\
\hline 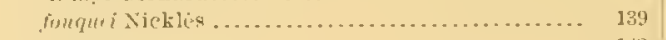 & stuaroceras Cossman .......................... 105 \\
\hline 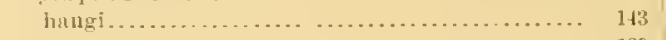 & stoliczliait........................ 104, note; 18̃, 110.141 \\
\hline 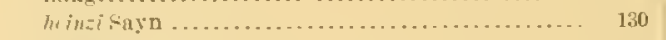 & tetrugona Neumuyr .................... 111 \\
\hline 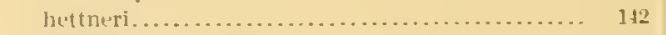 & styrucuceris Hy̆tt ....................... sò, m. 24t \\
\hline thlig......... & (Keyserling) .................. 89, =11-21; \\
\hline ............. 133.142 & subpulchellin Hyutt ................... 136, 137. 139-1 (1) \\
\hline klesi Hyatt.............................. 14 & 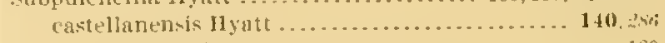 \\
\hline whle vicklis............................ 134 & fonquei (Nitkles)........... \\
\hline 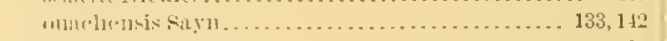 & nelderti (Nickles: .......................... 139 \\
\hline ulis d orbigny .................. 129, 130, 131,131 & savagenui (Hermite) ...................... 130,110 \\
\hline It dorbigny .......................... 13*, 140, 141 & 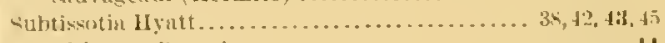 \\
\hline ui Iermitr......................... 139,140 & 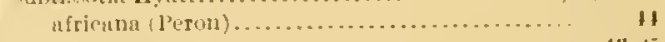 \\
\hline sehlumlergeri Nickles ... ................ 142 & influta (Peton) .............. \\
\hline 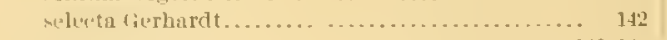 & intermedin (I'eron) $\ldots . . . .$. \\
\hline 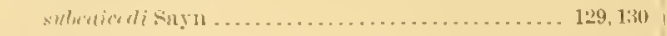 & furoni $\mathrm{H}$ yatt .............. \\
\hline ....... 30, 101; 104, 11016: $117,129,136-145$ & 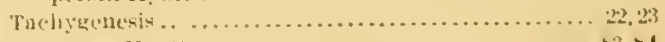 \\
\hline uturdation in development ............... 20-23, 189-190 & 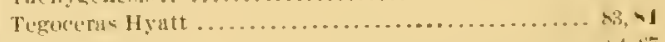 \\
\hline 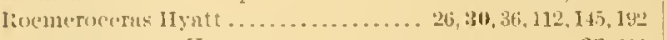 & 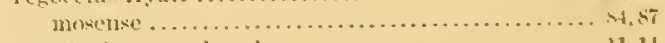 \\
\hline & mployed.......................... 11-11 \\
\hline 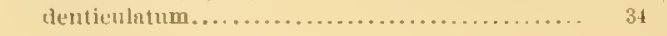 & Tissotia Donvillé............ 32, 35, 36, 34,41.42, 45, 55, 104, 178 \\
\hline
\end{tabular}


责 



\title{
PUBLICATIONS OF UNITED STATES GEOLOGISAL SURVE.
}

\author{
[Monograph XLIV.]
}

The serial publieations of the United States Geological Surver consist of (1) Annual Reports. (2) Monographs. (3) Professional Papers, (4) Bulletins, (5) Mineral Resonrees, (i) Water-Supply and Irrigation Papers, (7) Topographic Atlas of the United States-folios and separate sheets thereof. (s) Geologic Atlas of the United State-folios thereof. The classes numbered 2, 7. and s ale sold at cost of publication: the other's ale distributed free. A cirenlay giving complete lists may be had on application.

\section{IIONOGRAPHS.}

1. Lake Bonneville, by (․ K. (iilbert. 1890. $4^{\circ} . \mathrm{xx}, 438 \mathrm{pp} .51 \mathrm{pl} .1$ map. J'rice $\$ 1.50$. (Out of stork.)

1I. Tertiary history of the Grand Cañon district, with atlas, by C. E. Dutton, Capt., U. S. A. $1882.4^{\circ}$. xiv, $26^{2}+\mathrm{pp}$. 42 pl. and atlas of 24 sheets folio. Price $\$ 10$.

I11. Geology of the Comstock lode and the Washoe district, with atlas, by G. F. Becker. I88:2.

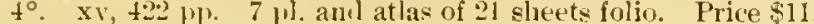

IV. Constock mining and miners, by Eliot Lorl. 1883. $4^{\circ}$. xiv, $451 \mathrm{pp} .3 \mathrm{pl}$. Price $\$ 1.50$

$\checkmark$. The copler-bearing rocks of Lake superior, by R. D. Irving. 1853. 40. xvi, ttit pp. 151 29 H. and maps. Price S1.85. (Unt of stock.)

V1. Contributions to the knowledge of the older Mesozos flora of Virginia, loy WV. MI. Fontaint. $1883.4^{\circ} . x i, 14 t$ l' 541.54 , 1. Price $\$ 1.05$.

VII. Silver-lead deposits of Eureka, Nevada, ly J. S. Curtis. 1584. 4․ xiii, 200 pl. 16 pl. Price SI.20.

VIII. Paleontology of the Eureka llistrict, by C. 1). Walcott. 1884. 4․ xiii, 298 pp. 24 l. 24 pl. Price 51.10

IX. Brachionda and Lamellibranchiata of the Raritan clays and greensand marls of New Jersey, ly R. P. Whitfield. 1885. $4^{\circ} . x x, 338$ p. 35 jil. 1 map. Price \$1.15.

X. Dinocerata. Amonogru,h of an extinct order of gigantic mammals, ly O. C. Marsh. 1886. 4․ xiii, $243 \mathrm{pp}$. 56 1. $56 \mathrm{pl}$. Price $\$ 2.70$

Il. Geological history of Lake Lahontan, a Quaternary lake of northwestem Nevada, by 1. C. Rusell. 1885. $4^{\circ}$. xiv, $288 \mathrm{pl} .46 \mathrm{pl}$. and maps. I'rice $\$ 1.75$.

XII. Cieology and mining industry of Leadville, Colorado, with atlas, by S. F. Emmons. 1856. $4^{\circ}$. xxix, $770 \mathrm{p}$. 45 pl. and atlas of 35 sleets folio. Price $\$ 8.40$.

X11I. Gerology of the quicksilver deposits of the l'acific slone, with atlas, by r. F. Becker. 1s8s, $4^{\circ}$. xix, 486 1'r. 7 pl. and atlas of 14 sheets follo. Price \$2.

X1V. Fossil theses and fossil plants of the Triasic moks of New Jersey and the Connecticut Valley,

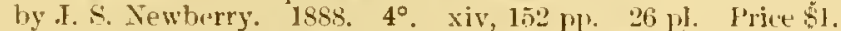

XV. The Potomac or younger Mesozoir flora, by W. M. Funtaine. 1889. 4. xiv, 377 pl. 180 pl. Text and plates lound separately. Price $\$ 2.50$.

XV1. The Pafeozoic tishes of North America, by J. S. Newbery. 1889. $4^{\circ}$. 340 pp. 53 pl. Price 51.00.

XVII. The florat of the Dakota group, a posthumons work, by Leo Lesugereux. Eslited lsy F. II. Knowlton. 1891. $4^{\circ} .400 \mathrm{pp} .66 \mathrm{pl}$. Price $\$ 1.10$.

XVIIl. Crasterupda and Cephaloporla of the Raritan elays and greensand marls of New Jersey, by R. P. Whitfield. $1891.44^{\circ}+112 \mathrm{pp} .50$ [1. P'rice 51

XIX. The Penokee iron-hearing series of northern Wisconsin and Michigan, ly R. D. Irving and C. R. Van Hise, 1892. $4^{\circ}$. xix, 534 $\mu 1$. Prire \$1.70.

XX. Geolngy of the Eureka district, Nevada, with an atlas, by Arnolu Hague. 1892. $4^{\circ}$. xvii, 4ly pr. $8 \mathrm{pl}$. Price $\$ 5.25$.

XX1. The Tertiary rhynehophorous Coleoptera of the Lnited states, lys S. H. Aculler. 1893. $4^{\circ}$. xi, $206 \mathrm{pr}$. 12 11. Price 90 cents.

IXII A manuil of tolographic methork, by Henry Gannett, ehief tonographer. 1893. $4^{\circ}$. xiv, 300 (1). 18 pl. Price $8 \mathbf{L}$.

XXII. Geolngy of the Freen Mountains in Maswachusetts, ly haplatel Pumpelly, T. N. Dale, and J. F. Wolff. 1s:9t. to. xiv, $206 \mathrm{pp} .23 \mathrm{pl}$. Price $\$ 1.30$.

110X XIII-1183-2:3 
XYIS. Mulluma and Crustacea of the Miocene formations of New Jersey, ly k. P. Whitfiehl. 1894. $4^{\circ} .193 \mathrm{ju} .24 \mathrm{ll}$. Price 90 cents.

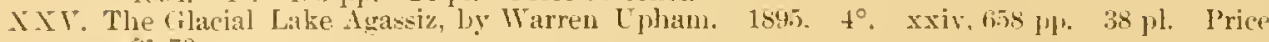
81.70 .

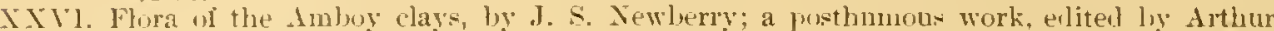

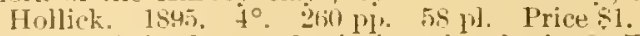

XXY11. Geology of the Denver Basin in Coloradn, by $\rightarrow$. F. Emmons, Whitman Cross, ant G. H. Eldrilge 18\%6. $4^{\circ} .556 \mathrm{pl} .31 \mathrm{pl}$. Price 31.50.

IXIIf. The Marquette iron-bearing district of Michigan, with atlas, by C. R. Van Hise and W... Bayley, including a chapter m the Republic twugh, by fl. L. Sinyth. 1895. $t^{\circ}$

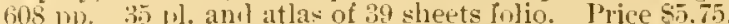

XXIX. Geology of oll Hanpshire County, Masachuetts, complsing Franklin, Hampshire, and Hamplen counties, ly B. K. Emerson. 189s. 40. xxi, 790 pl. 35 pl. Price $\$ 1.90$.

YYX. Fosil tledusie, by ( $D$ D. Walcott. 1898. $t^{\circ}$. ix, $201 \mathrm{pp}$. ti pl. Price $\$ 1.50$

XXX1. Geology of the Aspen mining district, Colorado, with atlas, ly J. E. Spurr. 1898. $4^{\circ}$ xxxi, $260 \mathrm{pp}$. $43 \mathrm{pl}$. and atlas of 30 sheets folio. Price $\$ 3.60^{\circ}$

IXY11. Geology of the Fellowstone National Park, Part II, descrittive geulogy, petrography, and paleontoliky, by Amolil Hague, J. P. Iddings, W. H. Weet, C. D. Wralcott, (i. H. Cirty

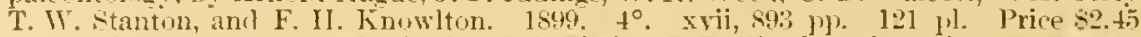

STXII. Genlogy of the Narragarisett Hasin, by N. S. Shaler, J. B. Woodworth, and A. F. Foerete. $15494^{\circ} . \quad \mathrm{xx}, 402 \mathrm{pp} .31 \mathrm{pl}$. Price 51.

KXXIs. The glacial gravels of llaine ant their associatert teposite, by G. H. Ntone. 1899. $4^{\circ}$ xiii, 494 (1). 52 jl. Prices1.30.

XXY. The later extinet tloras of North America, by d. S. Newberry; edited ly Arthur Hollick. 189. $4^{\circ}$. xriii, 245 1\%. 68 y. Price 81.25

IXIVI. The crrstal Falls iron-hearing district of lliehigan, by J. M. Clements and H. L. smyth: with a chapter on the Sturgeon River tongue, by $\mathbb{W}$. S. Bayley, and an introhuction ly. C. R. Tan Hise. 1809. $4^{\circ}$. xxxri, 512 pp. 53 pl. P'ice s?.

IXIV1I. Fussil flora of the Lnwer Cual Measures of Missouri, Wy David IVhite. 1si9. $4^{\circ} . \quad x i, 467$ 11. 73 y. Price 51.25.

XXXlll. The Illinoi glacial lobe, by Frank Leverett. 1899. $4^{\circ}$. xxi, 817 p. 24 pl. Price 81.60

XXXl. The Eocene and Lower Gligocene coral faunas of the Inited States, with descriptions of a few doubtiully Cretaceous species, hy T. W. Vaughan. 1900. $4^{\circ}$. $263 \mathrm{PP} .24 \mathrm{pl}$. Price $\$ 1.10$.

XL. Adepharous and clavicom Coleoptera from the Tertiary deposits at Florissant, Colorado, with descriftions wi a few other forms and a systematic list of the non-rhyncophorom Tertiary" Coleoptera of Jorth America, by S. H. Sculder. 1900. to. 14s pl. 11 pls. Prices 80 rents.

XL1. Glarial formations and drainage features of the Erie and (ohio lasins, by Frank Leverett.

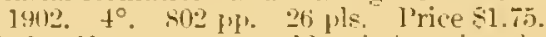

XLI1. Carbuniferons ammonoils of America, by J. P. Smith. 190\%. $t^{\circ} .211$ j'p. 29 pls. Price 85 cents.

XLIII. The Jesahi iron-bearing district of Jinnesota, by C. K. Leith. 1903. $4^{\circ} .316$ pl. 33 pls. Price $\$ 1.50$

XLIV. Psentuceratites of the Cretacens, by Alpheus Hyatt, edited by T. W. Stanton, 1903. $4^{\circ} .351 \mathrm{pl}$. ti pls. l'rice 81.00 .

All remittances must be hy noww onder, made parahle to the Dimetor of the United States Geologieal surver, or in CURRENCY-the exact amount. ('hecks, drafts. and postage stamps cau not be iccepted. Correspondence should be addressed to

\section{The DIRECTOR.}

UNited S'TATES Geological Sitriter.

May, 1903.

Mashixigtox. D. C 

. 

